

\section{DISCLAIMER}

This report was prepared as an account of work sponsored by an agency of the United States Government. Neither the United States Government nor any agency Thereof, nor any of their employees, makes any warranty, express or implied, or assumes any legal liability or responsibility for the accuracy, completeness, or usefulness of any information, apparatus, product, or process disclosed, or represents that its use would not infringe privately owned rights. Reference herein to any specific commercial product, process, or service by trade name, trademark, manufacturer, or otherwise does not necessarily constitute or imply its endorsement, recommendation, or favoring by the United States Government or any agency thereof. The views and opinions of authors expressed herein do not necessarily state or reflect those of the United States Government or any agency thereof. 


\section{DISCLAIMER}

Portions of this document may be illegible in electronic image products. Images are produced from the best available original document. 


\section{DISCLAIMER}

This document was prepared as an account of work sponsored by an agency of the United States Government. Neither the United States Government nor the University of California nor any of their employees, makes any warranty, express or implied, lor assumes any legal liability or responsibility for the accuracy, completeness, or usefulness of any information, apparatus, product, or process disclosed, or represents that its use would not infringe privately owned rights. Reference herein to any specific commercial products, process, or service by trade name, trademark, manufacturer, or otherwise, does not necessarily constitute or imply its endorsement, recommendation, or favoring by the United States Government or the University of California. The views and opinions of authors expressed herein do not necessarily state or reflect those of the United States Government or the University of California, and shall not be used for advertising or product endorsement purposes. .

Frinted in the United States of America Available from

National Technical Information Service U.S. Department of Commerce

5285 Port Royal Road

Springfield, VA 22161

Price

Page

Code

Range

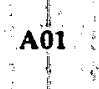

Papercopy Prices

Ao2

$\mathrm{AO2}$
$\mathrm{A03}$

A04

A05

A06

A07

A08

A09

\section{Microfiche}

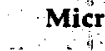

\section{DO NOT MICROFILM COVER}

$001-050$

051- 100

101-200

$201-300$

$301-400$

401-500

$501-600$

601 


\title{
Mechanical Properties of Heavy Oil-Sand and Shale as a Function of Pressure and Temperature
}

\author{
S. C. Blair \\ J. J. Sweeney \\ W. R. Ralph \\ D. G. Ruddle
}

Manuscript Date: July 1987

\section{DISCLAIMER}

This report was prepared as an account of work sponsored by an agency of the United States This report was prepared as an account of work spon any ancy thereof, nor any Government. Neither the United States Government nor any agency theral liability or responsiemployees, makes any warranty, express or implied, or assumes any legal liablity or roduct, or bility for the accuracy, completeness, or usefulness of any information, appanned rights. Referprocess disclosed, or represents that its use would not infringe privately ow name, trademark, ence herein to any specific commercial product, process, or service by trade norsement, recommanufacturer, or otherwise does not necessarily constitute or inply its end thereof. The views mendation, or favoring by the United States Government or any agency thect those of the

and opinions of authors expressed herein do not
United States Government or any agency thereof.

Final Report for Task D. Petrophysics Relating to Compaction of Annex IX, Subsidence due to Fluid States and the Ministry of Energy and Agreement between the Department of Energy of the United 
ABSTRACT . . . . . . . . . . . . . . . . . . . . . . 1

1. INTRODUCTION . . . . . . . . . . . . . . . . . . . . . 2

2. METHODOLOGY ........................... 3

2.1 CORE PREPARATION . . . . . . . . . . . . . . . . . . 3

2.2 TESTING METHODS . . . . . . . . . . . . . . . . . . 4

2.2.1 Triaxial Tests................. 4

2.2.2 Pressure-Volume Tests and Long-Term Creep Compaction Tests. 10

2.3 SAMPLE DESCRIPTION . . . . . . . . . . . . . . . . . 13

3. RESULTS . . . . . . . . . . . . . . . . . . . . 13

3.1 TASK D.1: PRESSURE-VOLUME BEHAVIOR AND THE EFFECT OF MECHANICAL

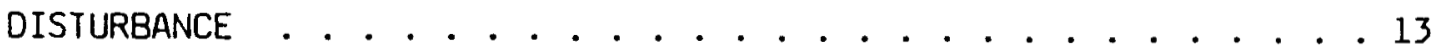

3.1.1 0il-Sand: Pressure-Volume Behavior . . . . . . . . . . 17

3.1.2 Dil-Sand: Effect of Disturbance . . . . . . . . . . 17

3.1.3 Undisturbed Shale: Pressure-Volume Behavior . . . . . . 23

3.1.4 Shale: Effect of Disturbance............ 23

3.2 TASK D.2: LABORATORY DETERMINATION OF PARAMETERS FOR MODEL SIMULATIONS: TRIAXIAL TESTS . . . . . . . . . . . . . 28

3.2.1 Oil-Sand Triaxial Tests............... 28

3.2 .2 Shale .................... 38

3.3 TASK D.3: LONG-TERM CREEP/COMPACTION BEHAVIOR . . . . . . . . . 48

3.3.1 Results of the Long-Term Creep Tests . . . . . . . . . . . 49

3.3.2 Long-Term Creep: Summary and Conclusions . . . . . . . 56 
4. SUMMARY AND CONCLUSIONS . . . . . . . . . . . . . . . . . . . . 59 ACKNOWLEDGMENTS . . . . . . . . . . . . . . . . . . 62

REFERENCES ............................ . 63 APPENDIX A--Tabulated Data for PV Tests on Undisturbed and Disturbed Samples of 0il-Sand and Shale ............... . . 64 APPENDIX B--Stress-Strain Plots and Tabulated Data for Triaxial Tests Conducted on 0il-Sand Samples . . . . . . . . . . . 70 APPENDIX C--Stress-Strain Plots and Tabulated Data for Triaxial Tests Conducted on Shale Samples . . . . . . . . . . . . 104 APPENDIX D--Tabulated Data for Long-Term Creep/Compaction Tests on Dil-Sand and Shale Samples ............... 150 
ABSTRACT

Laboratory tests were conducted to determine the mechanical properties of oil-sand and shale samples from the Faja region of Venezuela at elevated temperature and pressure. Results describe pressure-volume (PV) behavior at temperatures of 23 and $125^{\circ} \mathrm{C}$; the effect of mechanical disturbance on $P V$ behavior; EOS at temperatures of 23,125 , and $250^{\circ} \mathrm{C}$ and effective pressures to $150 \mathrm{MPa}$; and creep/compaction behavior at temperatures of 23 and $125^{\circ} \mathrm{C}$.

Data from PV tests on oil-sand show that increasing temperature from 23 to $125^{\circ} \mathrm{C}$ had very little effect on this material. Mechanical disturbance of oil-sand prior to PV testing lowered values of $K$. The compressive strength of oil-sand increased as effective pressure $\left(P_{E}\right)$ was raised and at both temperatures, samples tested at equivalent $P_{E}$ had similar strengths. Compressive strength of oil-sand seems to be controlled by the drainage of pore fluid during axial deformation. Nearly all oil-sand samples exhibited strain-hardening.

PV tests conducted on shale show that increasing temperature from 23 to $125^{\circ} \mathrm{C}$ reduced values of $\mathrm{K}$ one third. Mechanical disturbance significantly affected the PV response of shale samples due to the friable nature of the material. Data for shale samples tested in triaxial compression show that ultimate stress increases with increasing pressure and increasing temperature.

Results of long-term creep compaction tests show a linear change in sample volume as a function of the log of time and that the rate of volume change with time was larger at $125^{\circ} \mathrm{C}$ than at $23^{\circ} \mathrm{C}$ for both oil-sand and shale. 


\section{INTRODUCTION}

Heavy oil-sands often have an oil-plus-water content as high as $80 \%$. They have very low structural strength and exhibit extensive compaction when pore fluid is withdrawn. In Venezuela, where there are large deposits of heavy oil-sand, production of the petroleum from the oil-sand reservoirs has caused subsidence in some of the oil-producing regions. To anticipate the extent of subsidence and other reservoir behavior that might be caused by present or future oil production, the Venezuelan national oil organization, INTEVEP, has commissioned an extensive research program. Studies are under way to develop models that will predict subsidence and its effect on surface water movement. In addition, laboratory investigations of the mechanical properties of reservoir materials are being done to provide improved data for input to the models. As part of the laboratory research effort, the Earth Sciences Department at Lawrence Livermore National Laboratory has performed a series of laboratory tests on samples of the heavy oil-sand reservoir and shale caprock found in the Faja oil reservoir in eastern Venezuela. These tests were performed under Task $D$ of Article IX of Department of Energy/MEM Agreement. These tests will provide insight into the material behavior at conditions that simulate the in situ production environment.

The aim of laboratory tests performed at LLNL is to:

1. Provide guidance in the interpretation or use of laboratory data in reservoir modeling by determining the effect of mechanical disturbance on properties of core measured in the laboratory.

2. Provide equation-of-state (EOS) data for the mechanical properties of the oil-sand and shale caprock over a range of temperatures and pressures appropriate to in situ and production conditions in the Faja formation. The EOS data is required input for computer modeling of reservoir behavior and consists of stress-strain plots from triaxial tests.

3. Provide laboratory data on the long-term creep or secondary compaction properties of the oil-sand and shale materials at appropriate temperatures and pressures. These data are important for modeling the time-dependent behavior of the reservoir and caprock materials both during and subsequent to reservoir production. 
To provide the desired data, a sequence of laboratory tests was performed that included over 30 triaxial tests, 12 pressure-volume tests, and 15 long-term creep/compaction tests. In all, more than 56 samples were tested. This report documents the apparatus and testing methods, presents results and preliminary analyses of the test data, and includes tables of the reduced data as apppendices.

This report presents some of the first laboratory data on the mechanical behavior of shales and heavy oil-sands at temperatures to $250^{\circ} \mathrm{C}$ and pressures to $300 \mathrm{MPa}$. Results include pressure-volume (PV) relations for oil-sand and shale at two temperatures; quantitative results on the effect of mechanical disturbance on pressure-volume behavior; and Mohr-Coulomb failure envelopes, as a function of temperature, for oil-sand and shale. Other work on shales at elevated temperature is discussed by Johnston. ${ }^{1}$

It is important to note that this report is preliminary and results should be used carefully in any modeling effort. Tests at these conditions on unconsolidated or friable materials such as the oil-sand and shale are inherently difficult. We spent a great deal of time developing test techniques, and several test attempts were unsuccessful.

However, much new information is presented here. The experimental results provide insight into mechanisms important to the performance and stability of reservoir and caprock materials encountered by INTEVEP.

To perform measurements at the desired conditions (confining pressures to $300 \mathrm{MPa}$ and temperatures to $250^{\circ} \mathrm{C}$ ), several new pieces of apparatus were designed and constructed. These include a high-temperature triaxial vessel with capability for pore pressure control, an automated pore-fluid volumometer system, and two manual pore-fluid volumometer systems.

\section{METHODOLOGY}

\subsection{CORE PREPARATION}

Core samples of oil-sand and shale were received in a partially frozen condition and were immediately placed in a freezer and kept at $-20^{\circ} \mathrm{C}$. The lengths of core received were 0.5 to $1 \mathrm{~m}$ long. These pieces were cut into $10-\mathrm{cm}$ (4-inch) sections and returned to the freezer. Test specimens were prepared from the $10-\mathrm{cm}$ sections as follows. We constructed a watertight wooden 
"sandbox" large enough to hold several 10-cm sections (see Fig. 1). This box was placed in the freezer and allowed to come to equilibrium temperature. A quantity of clean 0ttawa sand sufficient to fill the box was also placed in the freezer. Core sections were then positioned in the box and sand was added to fill the box, so that only the ends of the core sections were exposed. Then very cold water was added slowly to the sand and allowed to freeze. Thus, the core sections were held firmly by the sand-ice mixture, which also kept the sections frozen during the coring operation. When the saturated sand was frozen, the bottom of the box was removed and test specimens were cored with a diamond-tipped core barrel at slow speeds. A silicone lubricant was used to enhance cutting. We cored each specimen individually and returned the sand box assembly to the freezer to refreeze the assembly before coring the next sample.

The test specimens were each wrapped with two layers of Teflon tape and one layer of plastic tape. Then they were cut to length with a diamond saw and lapped on a dry diamond lap wheel to obtain right-circular cylinders. Both 2.54-cm-diameter and 4.45-cm-diameter specimens were produced from the original oil-sand and shale cores. The plastic tape and one layer of Teflon tape were then removed, and specimens were weighed and measured. While the specimens were still frozen, they were converted into sample test assemblies as shown in Figs. 2 ( $a$ and $b$ ). Porous spacers (hastaloy disks) and endcaps were placed at the end of the specimens, and the entire assembly was jacketed with either viton shrink tubing (for tests at $23^{\circ} \mathrm{C}$ ) or fluorosilicone sealant (Dow Corning Q4-2817 for tests at higher temperatures). The pore fluid ports in the endcaps were sealed, and the jacketed specimens were allowed to warm to room temperature before testing.

\subsection{TESTING METHODS}

\subsubsection{Triaxial Tests}

Triaxial tests were performed on $2.54-\mathrm{cm}$-diameter samples. The apparatus used for triaxial testing is shown in Fig. 3 . The following procedure was used to perform the triaxial tests:

1. A jacketed sample was assembled into the test vessel, and the vessel was inserted into the press. 


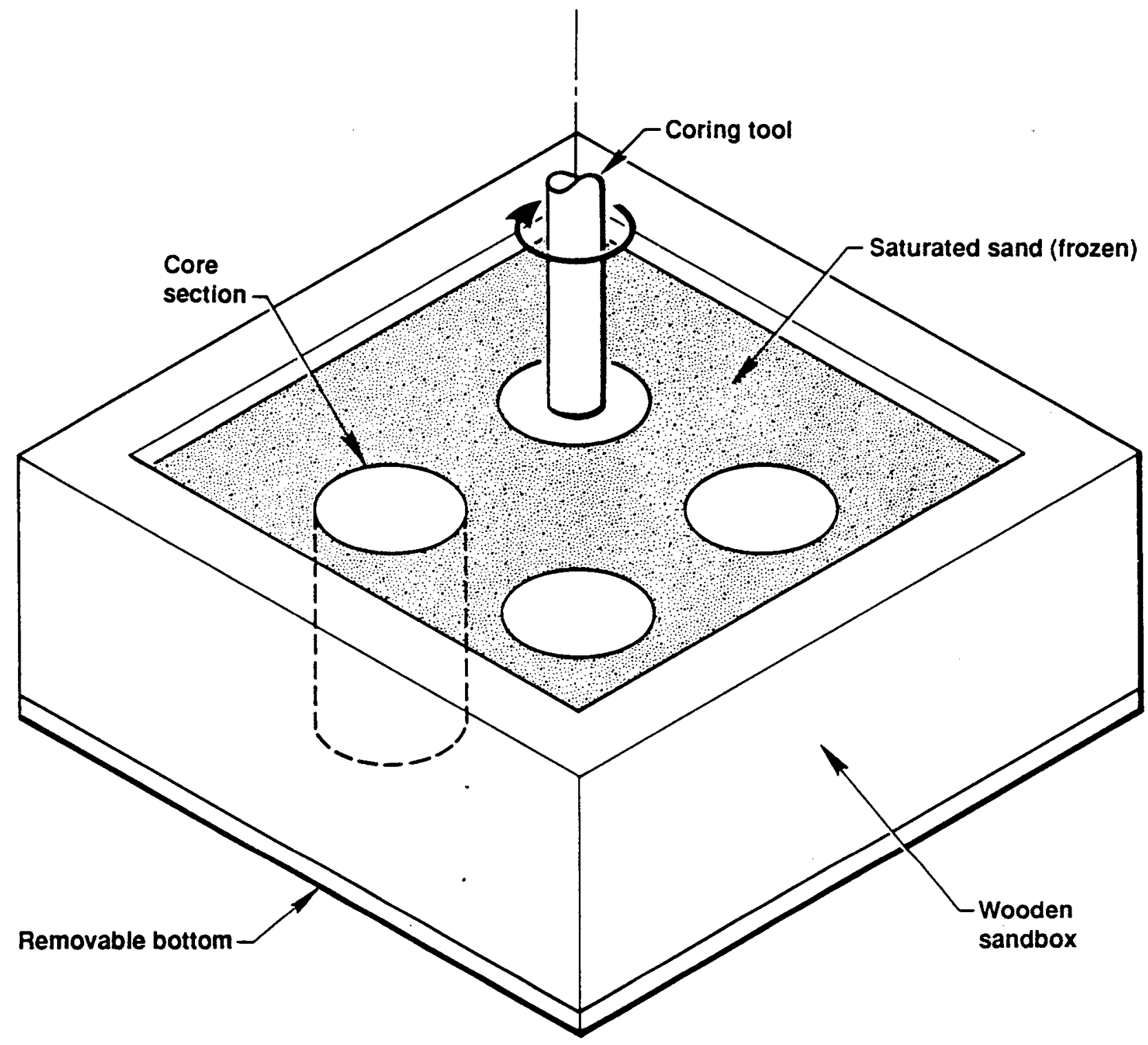

Figure 1. Sandbox assembly for coring samples while keeping them frozen. 


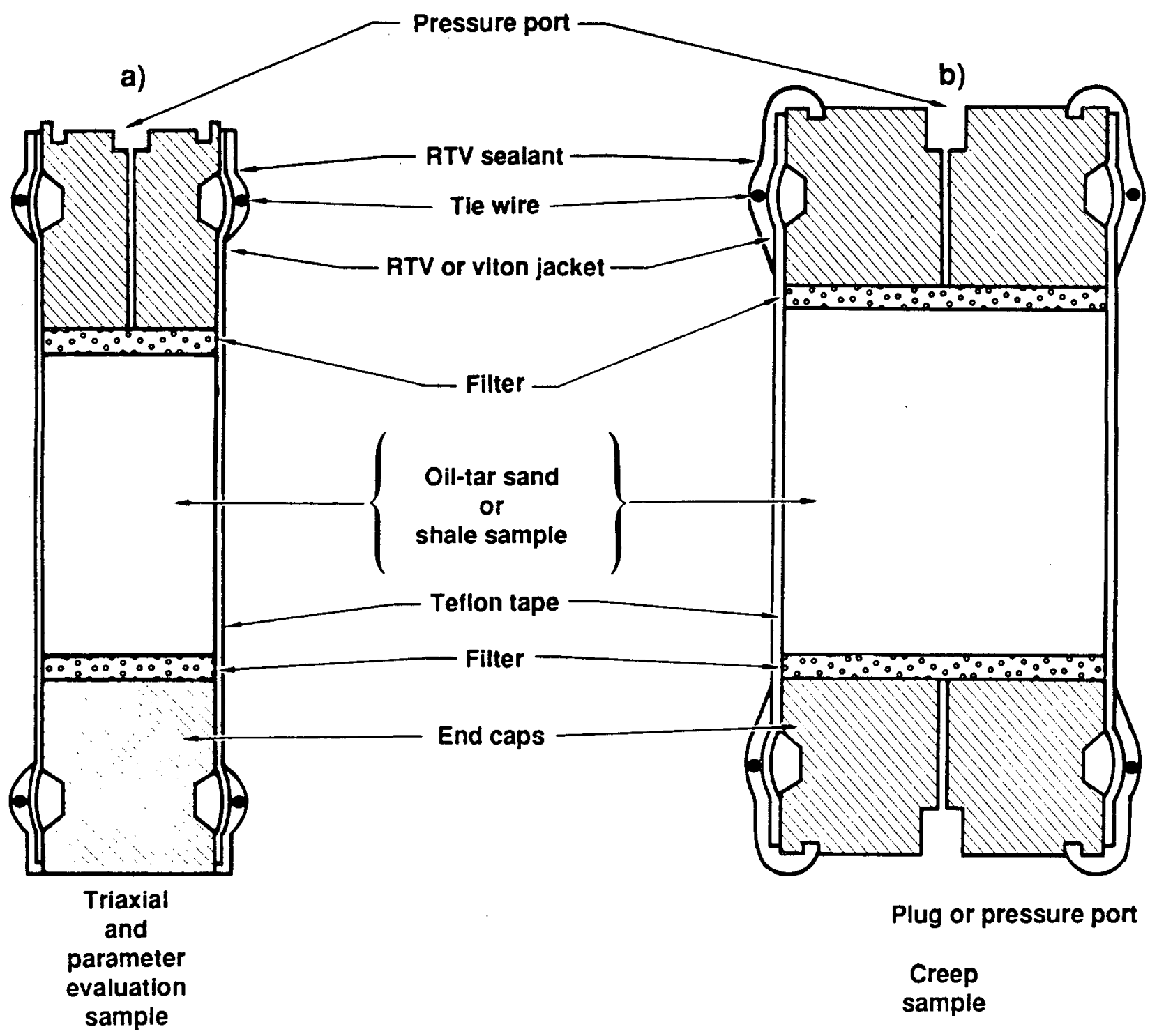

Figure 2. (a) Sample assembly for triaxial and PV tests; (b) sample assembly for long-term creep compaction tests. 


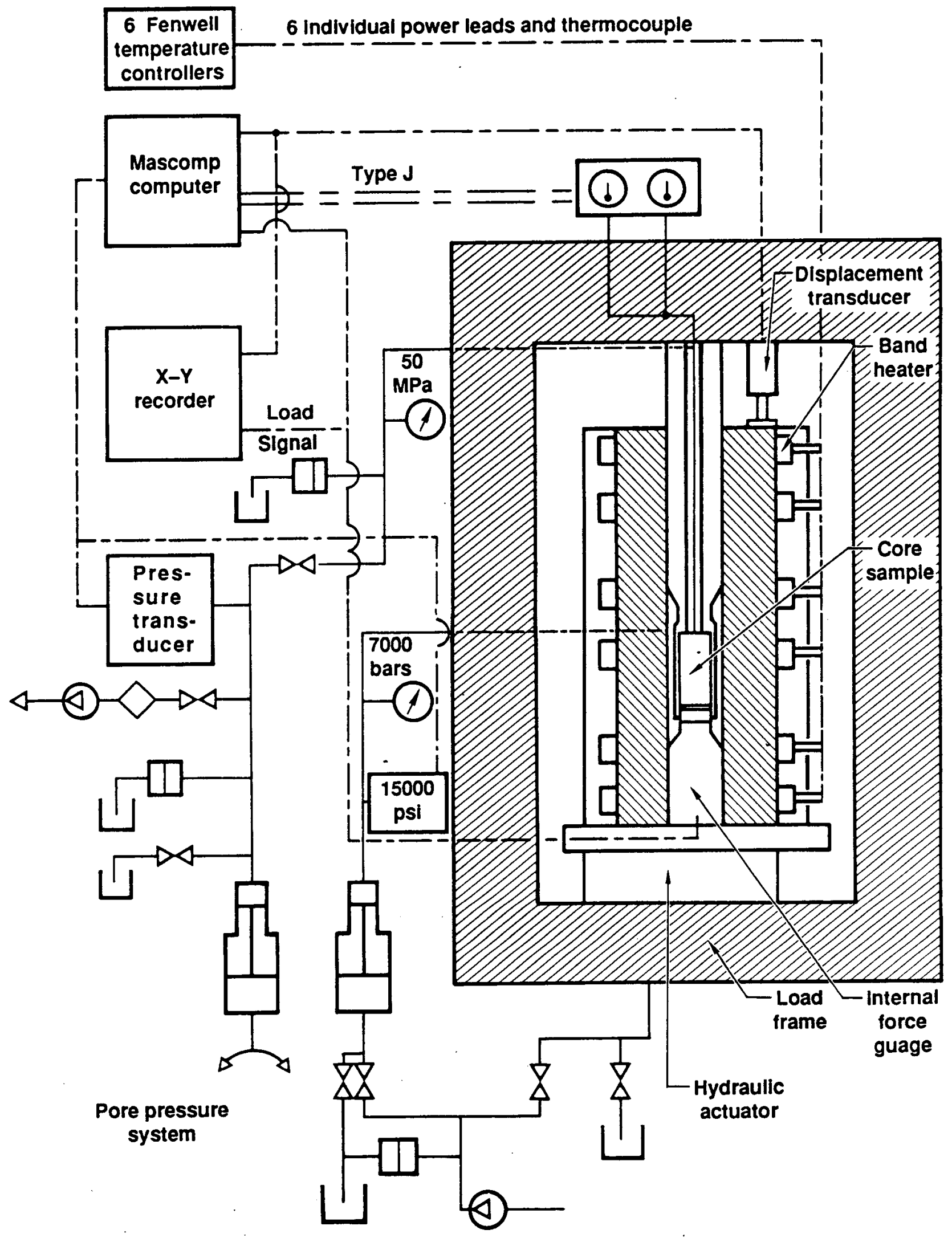

Confining and load system

Figure 3. Schematic diagram of triaxial apparatus. 


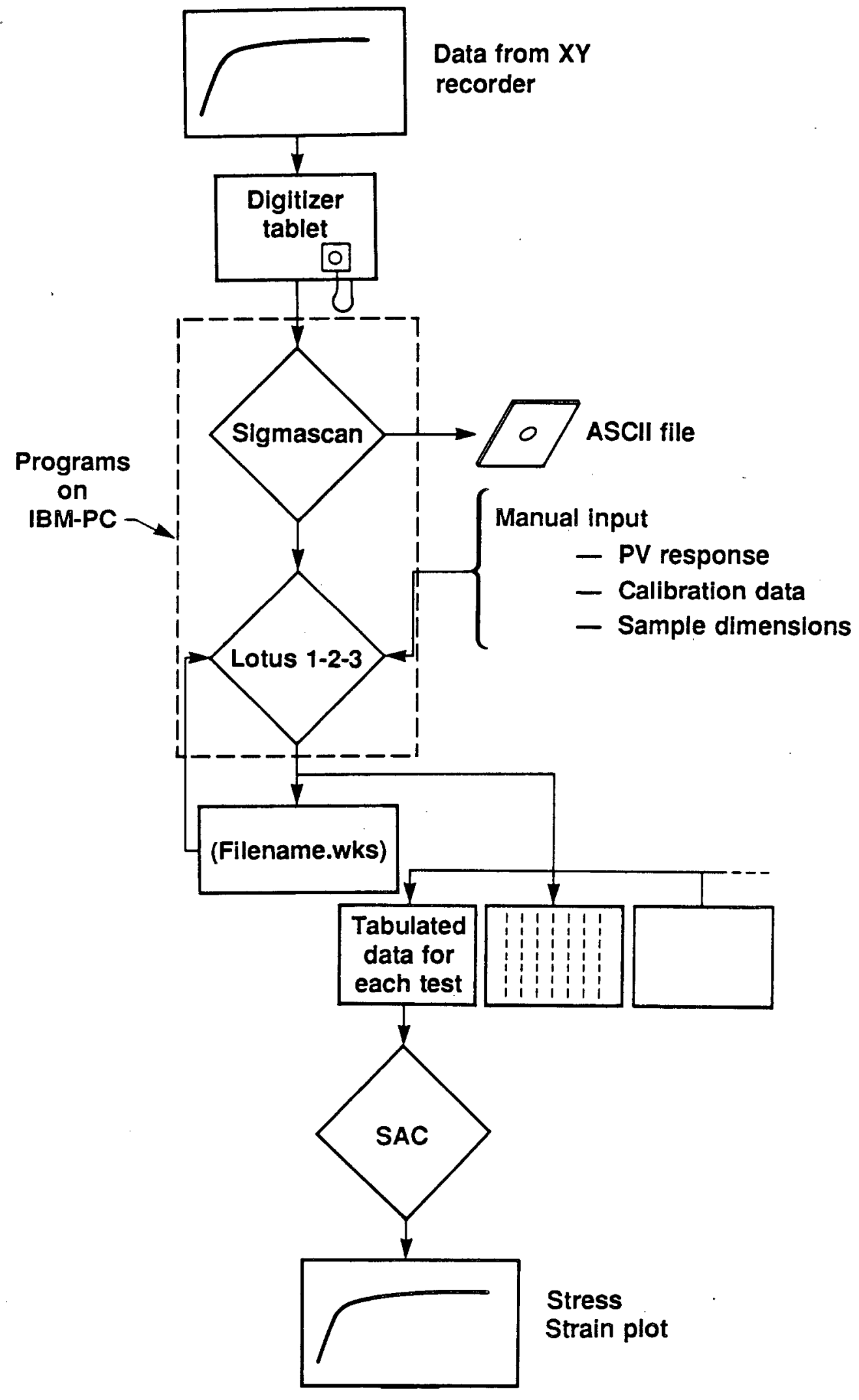

Figure 4. Data processing methodology for triaxial tests. 
2. The pore fluid line to the sample was evacuated and then filled with distilled water.

3. The vessel assembly was heated to test temperature. Confining and pore pressures were maintained at minimal levels during heating.

4. Confining and pore pressures were raised to desired levels, with pore pressure carefully maintained at one-half the confining pressure. The confining pressure was attained by a manually operated air-over-oil pump. Pore pressure was controlled manually using a calibrated volumometer.

5. Axial force was applied to deform the specimen with the desired amount of axial strain. Confining and pore pressures were maintained constant during the axial deformation.

Several parameters were recorded during these tests, including axial displacement, axial force on the sample, confining pressure, pore pressure, temperature of the sample, and volume of expelled pore fluid. Expelled pore volume during the period 2 to 5 min after the test was also noted. Data were recorded by both analog and digital recording devices. Volumometer displacement (change in pore volume) was recorded manually.

Data from the triaxial tests were reduced as follows. First, analog force/displacement charts were digitized with a digitizing tablet and the SIGMASCAN $^{2}$ program on an IBM PC. SIGMASCAN produced files of force and displacement values in an ASCII format. These ASCII files were read into LOTUS $1-2-3^{3}$ on an IBM PC, and data were reduced to stress and strain (the processing methodology is outlined in Fig. 4.) The reduced data were written to $x, y$ files from LOTUS $1-2-3$ and plotted using the SAC ${ }^{4}$ program at LLNL.

Two corrections were applied to the cross-sectional area to allow computation of axial stress. First, the cross section of the sample was corrected for deformation due to confining pressure. This correction was of the form:

$$
A_{P}=C_{P} A_{0} \text { where } 0<C_{P}<1.0 \text {, }
$$

where

$$
\begin{aligned}
& A_{p}=\text { area at effective pressure } \\
& A_{0}=\text { initial area } \\
& C_{p}=\text { pressure correction }
\end{aligned}
$$

We derived data for this correction from results of the PV tests conducted for Task D.2. Cross-sectional area of the sample was also corrected for the barrelling effect associated with axial deformation, using the relation

where e = axial strain.

$$
A_{p, e}=A_{p}(1+e) \text {, }
$$




\subsubsection{Pressure-Volume Tests and Long-Term Creep Compaction Tests}

Pressure-Volume (PV) tests monitored change in volume due to increasing hydrostatic prvssure. These tests were performed on 1-in.-diameter cores with the apparatus shown in Fig. 5. The following procedure represents the test sequence:

1. A jacketed sample was assembled into the test vessel.

2. The pore fluid line to the sample was evacuated and then filled with deionized water.

3. The vessel assembly was heated to test temperature. Confining and pore pressures were maintained at minimal levels during heating.

4. Confining and pore pressures were raised in incremental steps to a maximum confining pressure of $50 \mathrm{MPa}$, with pore pressure carefully maintained at $5 \mathrm{MPa}$. (While confining pressure was raised to $10 \mathrm{MPa}$, pore pressure was maintanined at $2.5 \mathrm{MPa}$.) Data were recorded at each pressure step.

5. Confining pressure was decreased in incremental steps, with pore pressure maintained at $5 \mathrm{MPa}$. Data were recorded at each step.

Apparatus for the long-term creep experiments is shown in Fig. 6. The long term, creep/compaction procedures for these tests were the same as steps 1 through 3 of the PV tests; then the confining and pore pressures were raised to the desired levels and maintained for long periods of time (weeks), with pore pressure maintained at one-half the confining pressure. Data were recorded several times a day during these tests.

Data for PV and long-term creep tests included initial sample volume, confining pressure, pore pressure, temperature, and volumometer displacement.

Data were recorded manually and with the A/D digital recording devices. We obtained manual measurements on the volumometer by measuring volumometer piston position at each confining pressure, using a dial caliper gauge for the PV tests and using a vernier scale for the long-term creep tests. The displacements were used to compute volume of expelled fluid.

Volumometer displacement, confining pressure, and pore pressure data were entered into the Lotus 1-2-3 program on an IBM PC. The volume of expelled fluid was calculated from the volumometer displacement. The change in volume of the sample was assumed to be equal to the volume of fluid expelled. 


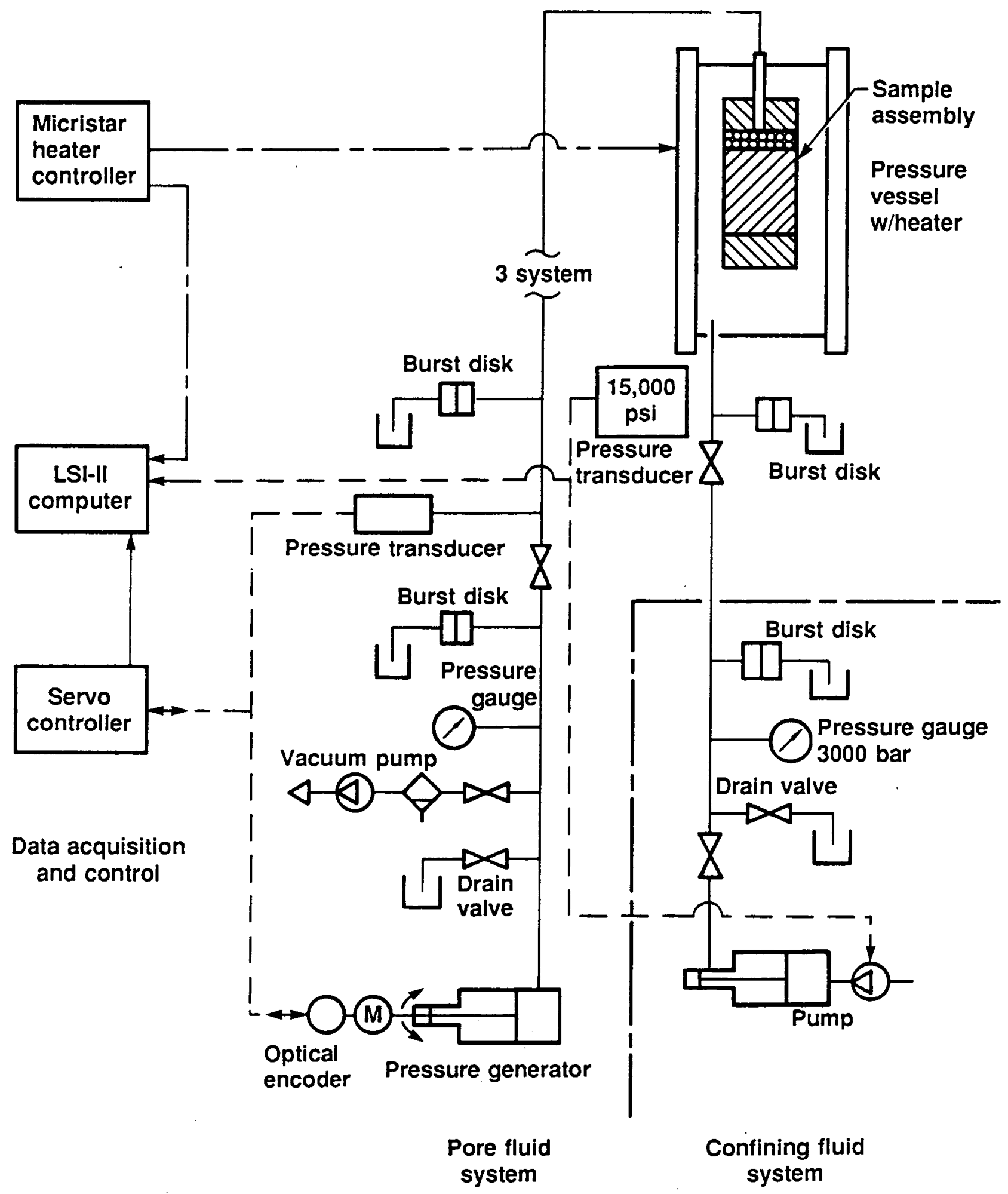

Figure 5. Apparatus for INTEVEP parameter evaluation. 


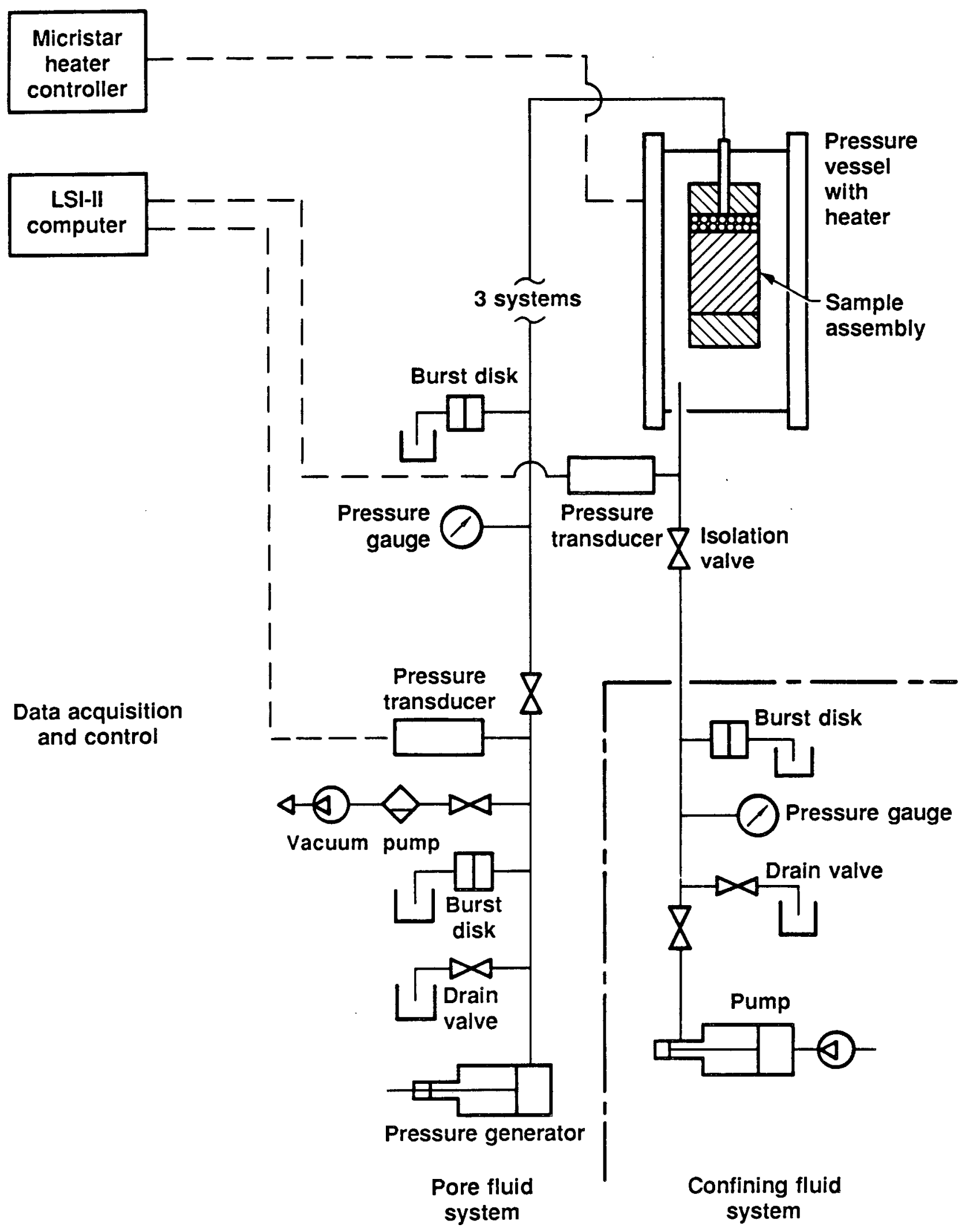

Figure 6. INTEVEP long-term creep/compaction test apparatus. 


\subsection{SAMPLE DESCRIPTION}

Core from the Faja region consisted of shale samples from depths between 3202 and $3211 \mathrm{ft}$ and oil-sand samples from depths between 3278 and $3280 \mathrm{ft}$ and between 3307 and $3309 \mathrm{ft}$. Core sections and general core description are listed in Table 1; Table 2 presents a complete list of samples, depths, densities, and other specimen information.

The oil-sand samples had an average wet density of $1.89 \mathrm{~g} / \mathrm{cc}$ (standard deviation $=0.05)$, and the average wet density of the shale samples was $2.0 \mathrm{~g} / \mathrm{cc}$ (standard deviation =0.1). We did not determine dry density, porosity, or void ratio for the samples because specialized equipment, not available at LLNL, is required to accurately measure these parameters on materials saturated with organic fluids and water. We recommend that core samples be analyzed for porosity and oil/water content by one of the many commercial laboratories that specialize in this type of testing.

\section{RESULTS}

\subsection{TASK D.1 PRESSURE-VOLUME BEHAVIOR AND THE EFFECT OF MECHANICAL}

\section{DISTURBANCE}

We conducted PV tests on oil-sand and shale samples at 23 and $125^{\circ} \mathrm{C}$. To determine the effect of disturbance on the PV behavior at each temperature, we tested undisturbed specimens and specimens that had been strained to 5 and 10\% of their axial length in unconfined triaxial tests (see Task D.2).

The tests were conducted as described in Section 2.2.2. In reducing the data, we assumed that the total change in volume of the sample could be approximated by the amount of fluid expelled from the sample measured by the volumometer. During these tests, confining pressure was raised in increments of $10 \mathrm{MPa}$ (except at very low pressures), and pore pressure was held constant at $5 \mathrm{MPa}$ by using a servo-controlled pore fluid volumometer. At each effective pressure, the displacement of the volumometer was digitally and manually recorded after the volumometer had reached an equilibrium position. The change in pore volume was directly computed from the displacement of the volumometer. Values were normalized to the initial volume of the sample before any disturbance was introduced. 
Table 1. Core depth and descriptions Intevep well, MFB-264.

DEPTH DESCRIPTION

$3202^{\prime}$

$3204^{\prime}$

$3206^{\prime}$

$3207^{\prime}$

$3210^{\prime}$

$3211^{\prime}$

$3278^{\prime}-10^{\prime \prime}$

$3279^{\prime}-10^{\prime \prime}$

$3280^{\prime}-10^{\prime \prime}$

$3307^{\prime}-10^{\prime \prime}$

$3308^{\prime}-10^{\prime \prime}$

$3309^{\prime}-6^{\prime \prime}$
Grey, fine grained rock

with black, oil-rich stringers

(Shale caprock for the reservoir)
Black, oil-rich material

$\sim 80 \%$ Hydrocarbon

(Re: Luis Roca)

Black, oil-rich material

Similar to above core 
Table 2. Specimen description.

Test Conditions

Wet

\begin{tabular}{|c|c|c|c|c|c|c|c|c|c|c|}
\hline $\begin{array}{l}\text { Sample } \\
\text { No. }\end{array}$ & Depth & Type & $\begin{array}{c}\text { Strain } \\
(\%)\end{array}$ & $\begin{array}{c}\text { Temperature } \\
\left({ }^{\circ} \mathrm{C}\right)\end{array}$ & $\begin{array}{c}\text { Pressure } \\
\text { (MPa) }\end{array}$ & $\begin{array}{l}\text { Length } \\
(\mathrm{cm})\end{array}$ & $\begin{array}{c}\text { Diameter } \\
(\mathrm{cm})\end{array}$ & $\begin{array}{l}\text { Volume } \\
\text { (cc) }\end{array}$ & $\begin{array}{c}\text { Weight } \\
(\mathrm{gm})\end{array}$ & $\begin{array}{l}\text { Density } \\
(\mathrm{gm} / \mathrm{cc})\end{array}$ \\
\hline 1 & $3204^{\prime}$ & $\mathrm{SH}$ & 10 & 23 & 50.0 & 5.718 & 2.489 & 27.824 & 54.00 & 1.94 \\
\hline 2 & $3204^{\prime}$ & SH & 10 & 23 & 20.0 & 4.496 & 2.560 & 23.146 & 47.00 & 2.03 \\
\hline 3 & $3204^{\prime}$ & $\mathrm{SH}$ & 10 & 23 & 0.1 & 5.060 & 2.545 & 25.740 & 54.00 & 2.10 \\
\hline 4 & $3206^{\prime}$ & $\mathrm{SH}$ & 10 & 23 & 0.1 & 3.708 & 2.576 & 19.321 & 41.10 & 2.13 \\
\hline 5 & $3206^{\prime}$ & $\mathrm{SH}$ & 5 & 23 & 0.1 & 3.744 & 2.530 & 18.819 & 41.25 & 2.19 \\
\hline 6 & $3206^{\prime}$ & $\mathrm{SH}$ & 10 & $(134) / 125$ & 0.1 & 3.860 & 2.550 & 19.655 & 39.38 & 2.00 \\
\hline 7 & $3202^{\prime}$ & SH & 5 & $(134) / 125$ & 0.1 & 5.190 & 2.660 & 28.797 & 52.86 & 1.84 \\
\hline 8 & $3202^{\prime}$ & SH & 10 & 250 & 0.1 & 5.100 & 2.620 & 27.510 & 53.14 & 1.93 \\
\hline 9 & $3204^{\prime}$ & $\mathrm{SH}$ & 10 & 23 & 270.0 & 5.131 & 2.500 & 25.17 & 52.02 & 2.07 \\
\hline 10 & $3279^{\prime} 10^{\prime \prime}$ & OS & 10 & 23 & 0.1 & 4.864 & 2.540 & 24.647 & 45.94 & 1.86 \\
\hline 11 & $3308^{\prime} 10^{\prime \prime}$ & OS & 5 & 23 & 0.1 & 4.869 & 2.530 & 24.426 & 45.10 & 1.85 \\
\hline 12 & $3206^{\prime}$ & $\mathrm{SH}$ & 10 & 23 & 10.0 & 5.070 & 2.535 & 25.574 & 52.20 & 2.04 \\
\hline 13 & $3206^{\prime}$ & $\mathrm{SH}$ & 10 & 23 & 5.0 & 3.600 & 2.510 & 17.826 & 30.38 & 1.70 \\
\hline 14 & $3210^{\prime}$ & SH & 10 & 23 & 2.0 & 3.551 & 2.630 & 19.274 & 37.92 & 1.97 \\
\hline 15 & $3307^{\prime} 10^{\prime \prime}$ & OS & 10 & 23 & 50.0 & 4.844 & 2.510 & 23.958 & 46.70 & 1.95 \\
\hline 16 & $3308^{\prime} 10^{\prime \prime}$ & OS & 10 & 23 & 20.0 & 4.674 & 2.490 & 22.837 & 43.64 & 1.91 \\
\hline 17 & $3307^{\prime} 10^{\prime \prime}$ & OS & 10 & 23 & 10.0 & 4.989 & 2.517 & 24.824 & 46.30 & 1.87 \\
\hline 18 & $3308^{\prime} 10^{\prime \prime}$ & OS & 10 & 23 & 5.0 & 4.834 & 2.565 & 25.011 & 46.46 & 1.86 \\
\hline 19 & $3307^{\prime} 10^{\prime \prime}$ & OS & 10 & 125 & 50.0 & 4.737 & 2.527 & 23.764 & 42.54 & 1.79 \\
\hline 20 & $3308^{\prime} 10^{\prime \prime}$ & OS & 10 & 125 & 20.0 & 4.765 & 2.504 & 23.473 & 44.06 & 1.88 \\
\hline $20 A$ & "3307'10" & OS & 10 & 125 & 20.0 & 4.575 & 2.527 & 22.95 & 43.84 & 1.91 \\
\hline 21 & $3308^{\prime} 10^{\prime \prime}$ & OS & 10 & 125 & 10.0 & 4.745 & 2.517 & 23.611 & 46.34 & 1.96 \\
\hline 22 & $3210^{\circ}$ & $\mathrm{SH}$ & 10 & 125 & 10.0 & 4.877 & 2.578 & 25.458 & 50.32 & 1.98 \\
\hline 23 & $3202^{\prime}$ & $\mathrm{SH}$ & $5 / 10$ & 125 & 0.1 & 3.937 & 2.578 & 20.552 & 41.82 & 2.03 \\
\hline 24 & $3308^{\prime} 10^{\prime \prime}$ & OS & 10 & 125 & 0.1 & 5.141 & 2.375 & 22.773 & 43.84 & 1.93 \\
\hline 25 & $3308^{\prime} 10^{\prime \prime}$ & OS & 5 & 125 & 0.1 & 4.272 & 2.502 & 21.003 & 40.00 & 1.90 \\
\hline
\end{tabular}




\begin{tabular}{|c|c|c|c|c|c|c|c|c|c|c|}
\hline $\begin{array}{l}\text { Sample } \\
\text { No. }\end{array}$ & Depth & Type & $\begin{array}{c}\text { Test } \\
\text { Strain } \\
(\%)\end{array}$ & $\begin{array}{c}\text { nditions } \\
\text { Temperature } \\
\left({ }^{\circ} \mathrm{C}\right)\end{array}$ & $\begin{array}{c}\text { Pressure } \\
\text { (MPa) }\end{array}$ & $\begin{array}{c}\text { Length } \\
(\mathrm{cm})\end{array}$ & $\begin{array}{l}\text { Diameter } \\
(\mathrm{cm})\end{array}$ & $\begin{array}{l}\text { Volume } \\
\text { (cc) }\end{array}$ & $\begin{array}{c}\text { Wet } \\
\text { Weight } \\
\text { (gm) }\end{array}$ & $\begin{array}{l}\text { Density } \\
(\mathrm{gm} / \mathrm{cc})\end{array}$ \\
\hline 26 & $3202^{\prime}$ & SH & 10 & 125 & 20.0 & 4.890 & 2.502 & 24.038 & 48.58 & 2.02 \\
\hline $26 A$ & $3211^{\prime}$ & $\mathrm{SH}$ & 10 & 125 & 20.0 & 3.602 & 2.609 & 19.25 & 40.24 & 2.09 \\
\hline 27 & $3211^{\prime}$ & $\mathrm{SH}$ & 10 & 125 & 25.0 & 4.529 & 2.515 & 22.49 & 45.92 & 2.04 \\
\hline $27 A$ & $3211^{\prime}$ & SH & 10 & 125 & 50.0 & 4.803 & 2.578 & 25.073 & 48.92 & 1.95 \\
\hline $27 B$ & $3202^{\prime}$ & SH & 10 & 125 & 50.0 & 3.635 & 2.565 & 18.79 & 36.16 & 1.92 \\
\hline 28 & $3202^{\prime}$ & $\mathrm{SH}$ & 10 & 250 & 0.1 & 3.884 & 2.525 & 19.718 & 40.32 & 2.04 \\
\hline 29 & $3202^{\prime}$ & $\mathrm{SH}$ & 5 & 250 & 0.1 & 3.762 & 2.591 & 19.831 & 40.00 & 2.02 \\
\hline 30 & $3308^{\prime} 10^{\prime \prime}$ & OS & 5 & 250 & 0.1 & 4.844 & 2.499 & 23.765 & 46.46 & 1.95 \\
\hline 31 & $3308^{\prime} 10^{\prime \prime}$ & OS & 10 & 250 & 0.1 & 4.801 & 2.629 & 26.057 & 48.46 & 1.86 \\
\hline 32 & $3280^{\prime} 10^{\prime \prime}$ & OS & 10 & 125 & 300.0 & 5.139 & 2.520 & 25.61 & 46.60 & 1.82 \\
\hline 33 & $3210^{\prime}$ & SH & 10 & 125 & 300.0 & 4.092 & 2.578 & 21.36 & 43.48 & 2.04 \\
\hline 34 & $3211^{\prime}$ & SH & 10 & 250 & 300 & 3.620 & 2.642 & 19.84 & 40.70 & 2.05 \\
\hline
\end{tabular}




\subsubsection{Oil-Sand: Pressure-Volume Behavior}

The PV data for undisturbed oil-sand at 23 and $125^{\circ} \mathrm{C}$ are plotted in Fig. 7; tabulated values are in Appendix $A$. These data indicate that at $23^{\circ} \mathrm{C}$ the undisturbed oil-sand sample behaved like a saturated sand. Bulk modulus for this sample increased from $430 \mathrm{MPa}$ for effective pressures below $25 \mathrm{MPa}$ to 670 $\mathrm{MPa}$ for effective pressures in the range 25 to $45 \mathrm{MPa}$. As effective pressure was decreased, the sample recovered only a very small portion of the volume, indicating that permanent compaction of pore space occurred as pore fluid drained from the saturated sand. Results for the undisturbed sample tested at $125^{\circ} \mathrm{C}$ indicate that raising effective pressure to $5 \mathrm{MPa}$ caused a volumetric strain of $\sim 5 \%$. As effective pressure was increased above $5 \mathrm{MPa}$, this sample responded in a nearly identical way to that of the one tested at $23^{\circ} \mathrm{C}$. This can be verified by comparing the bulk moduli over equivalent pressure ranges (Table 3).

These data indicate that the bulk modulus of the "undisturbed" heavy oil-sand samples was $430-670 \mathrm{MPa}$. Increasing the temperature on an unconfined sample to $125^{\circ} \mathrm{C}$ caused thermal cracking or some other type of sample expansion and created about $5 \%$ void space. However, when effective pressure was increased to $5 \mathrm{MPa}$ or more, the void space closed and the rock behaved as it would at room temperature. This implies that at in situ reservoir pressures, heating the oil-sand to $125^{\circ} \mathrm{C}$ will have little effect on the bulk modulus. These data also indicate that, at both temperatures, the decrease in volume with increasing effective pressure was caused by permanent pore compaction that occured as pore fluid was expelled from the sample.

A PV test attempted on oil-sand samples at $250^{\circ} \mathrm{C}$ was unsuccessful because the sample jacket ruptured.

\subsubsection{0il-Sand: Effect of Disturbance}

Data for PV tests conducted on undisturbed and disturbed oil-sand samples at $23^{\circ} \mathrm{C}$ are shown in Fig. 8. Disturbed samples were strained to 5 or $10 \%$ axial strain at unconfined conditions (see Section 3.2.1) prior to the PV tests. These data show that, as effective pressure was raised to $2.5 \mathrm{MPa}$, the two disturbed samples lost approximately $6 \%$ of their volume, which is consistent if 


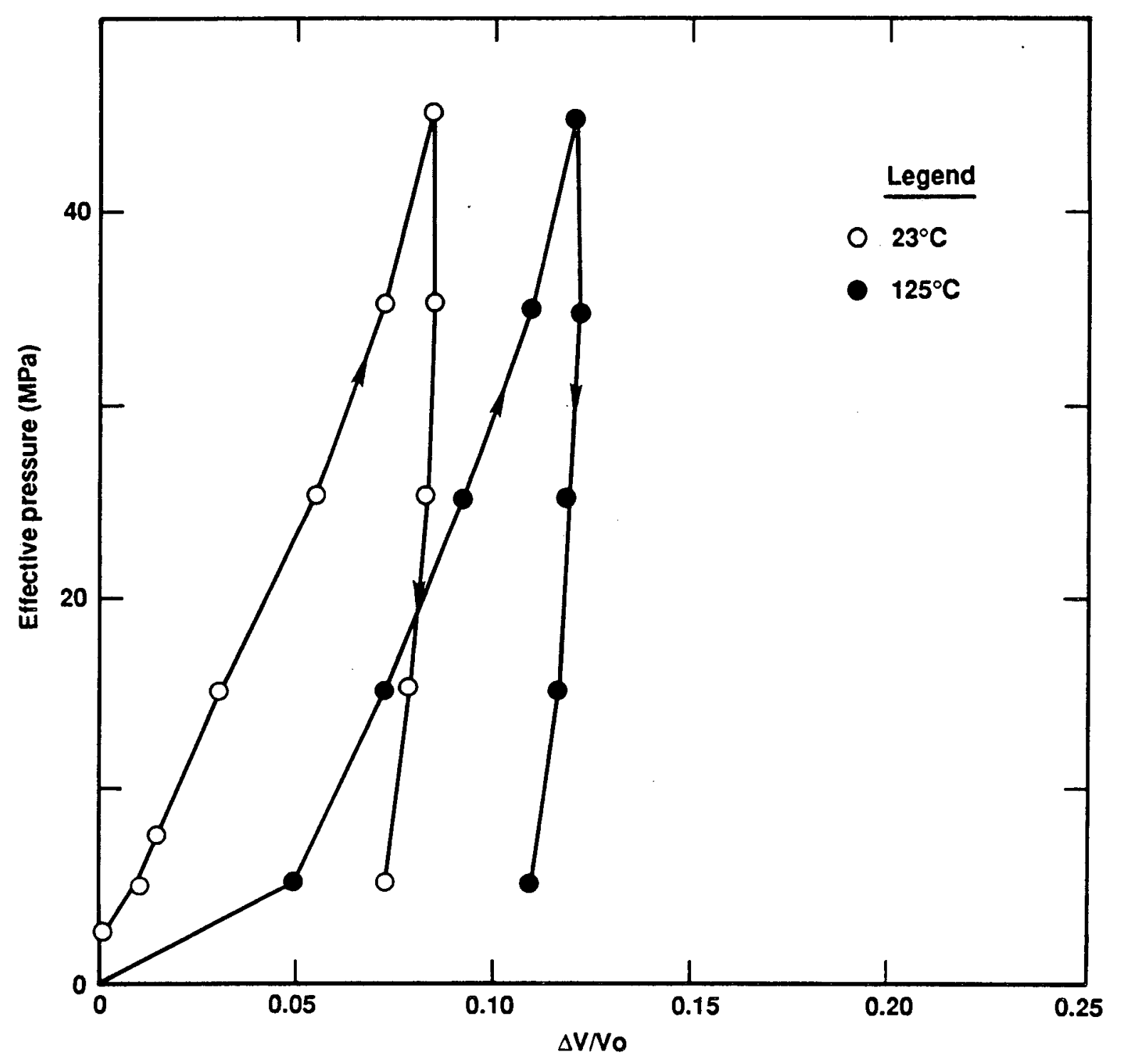

Figure 7. The PV data for oil-sand at 23 and $125^{\circ} \mathrm{C}$. 
Table 3. Bulk modulus of oil-sand and shale at 23 and $125^{\circ} \mathrm{C}$.

\begin{tabular}{|c|c|c|c|c|c|c|}
\hline Temperature & & Oil-Sand & & Sha & & \\
\hline & & $5 \%$ & $10 \%$ & & $5 \%$ & $10 \%$ \\
\hline & Undisturbed & Disturbed & Disturbed & Undisturbed & Disturbed & Disturbed \\
\hline $23^{\circ} \mathrm{C}$ & 670 & 555 & 4000 & 2100 & 800 & 1000 \\
\hline $125^{\circ} \mathrm{C}$ & 670 & $--^{*}$ & 1176 & 1660 & 1000 & 1176 \\
\hline
\end{tabular}

*Unsuccessful test. 


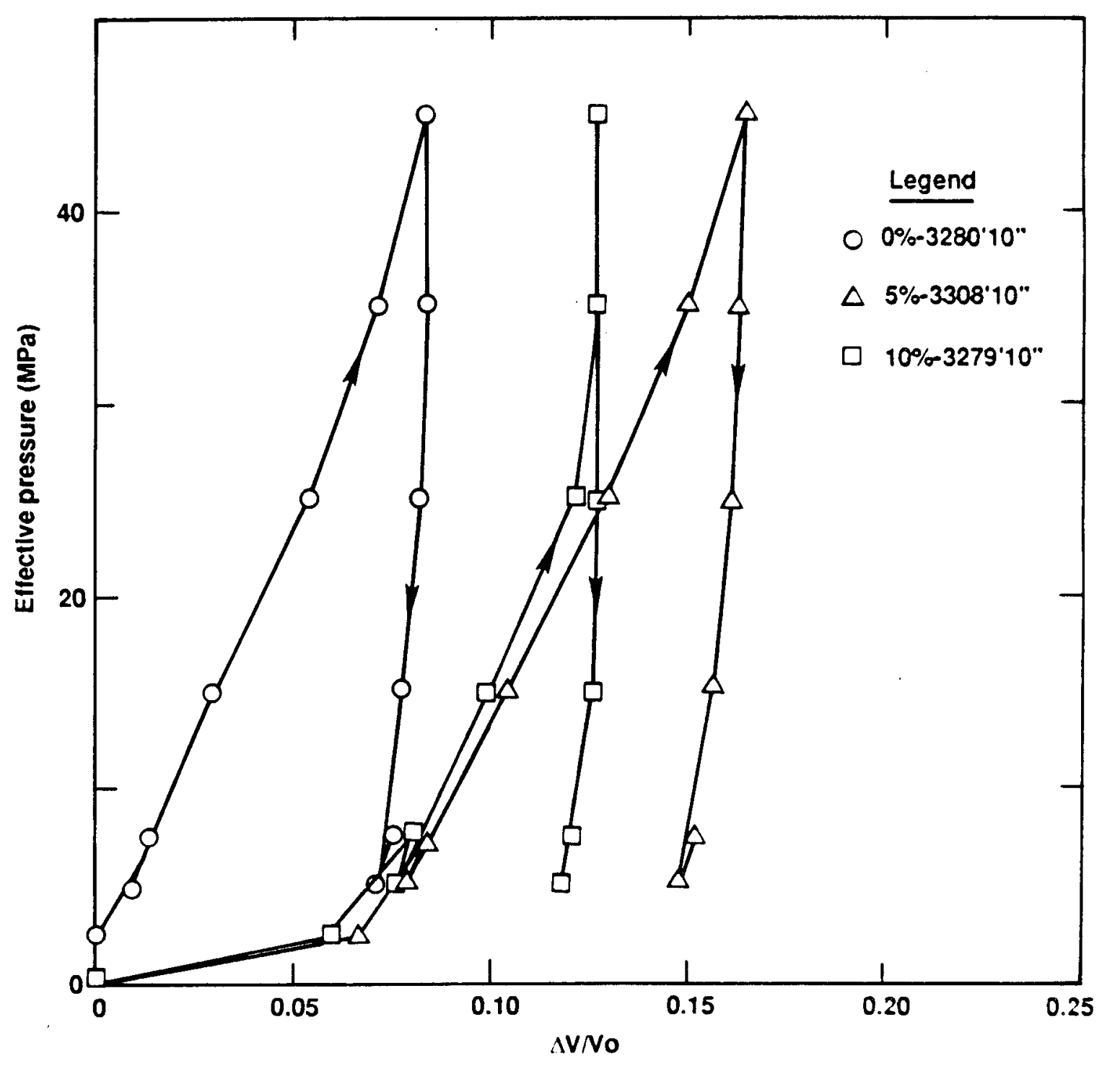

Figure 8. The PV data for undisturbed and disturbed oil-sand at $23^{\circ} \mathrm{C}$. 
one assumes that cracks closed and other void spaces were introduced during unconfined axial compression. As effective pressure was increased from 2.5 to $25 \mathrm{MPa}$, both disturbed samples showed similar behavior and compacted at nearly the same rate as the undisturbed sample in this pressure range. As effective pressure was raised above $25 \mathrm{MPa}$, the $5 \%$ sample continued to compact at a rate similar to the undisturbed sample while the sample with $10 \%$ disturbance compacted very little and behaved as a highly consolidated sand with no apparent change in pore volume.

The results of these tests indicate that void space introduced by disturbance of 5-to-10\% axial strain closes at effective pressures greater than $7.5 \mathrm{MPa}$. However, a disturbance of $10 \%$ strain appears to have introduced some permanent compaction into the sample.

Data for undisturbed and disturbed oil-sand tested at $125^{\circ} \mathrm{C}$ are plotted in Fig. 9. The disturbed samples were tested at $125^{\circ} \mathrm{C}$ in the triaxial apparatus (see Section 2.2.1). The samples were removed from the triaxial vessel after it had cooled to room temperature. The pore fluid ports were sealed, and the samples were stored at room temperature until they were tested in the PV apparatus. The jacket on the $5 \%$ disturbed sample ruptured when effective pressure was raised to $5 \mathrm{MPa}$; thus, only one data point was available for this sample. The results show that at $125^{\circ} \mathrm{C}$, the initial compaction for disturbed samples was greater than that for the undisturbed sample. However, the behavior was similar to that of disturbed samples at $23^{\circ} \mathrm{C}$. In the pressure range 5 to $25 \mathrm{MPa}$, we again see that the disturbed sample behaved similarly to the undisturbed sample. As pressure was raised above $35 \mathrm{MPa}$, the 10\% sample showed no observable compaction, indicating that (as before) a $10 \%$ disturbance caused some permanent compaction of pore space in the sample.

The oil-sand data indicate that the disturbances of 5 and 10\% introduced void space equal to $5-7 \%$ of the initial volume into the samples. This void space closed as effective pressure was raised to $7.5 \mathrm{MPa}$. A disturbance of 10\% appears to have introduced some permanent compaction into the oil-sand. At effective pressures below $25 \mathrm{MPa}$, the $10 \%$ disturbed material behaved similarly to that disturbed only 5\%; but as effective stress was raised above $25 \mathrm{MPa}$, the $10 \%$ material became very stiff. Temperature had very little effect because the disturbed material behavior at $125^{\circ} \mathrm{C}$ was similar to its behavior at $23^{\circ} \mathrm{C}$. 


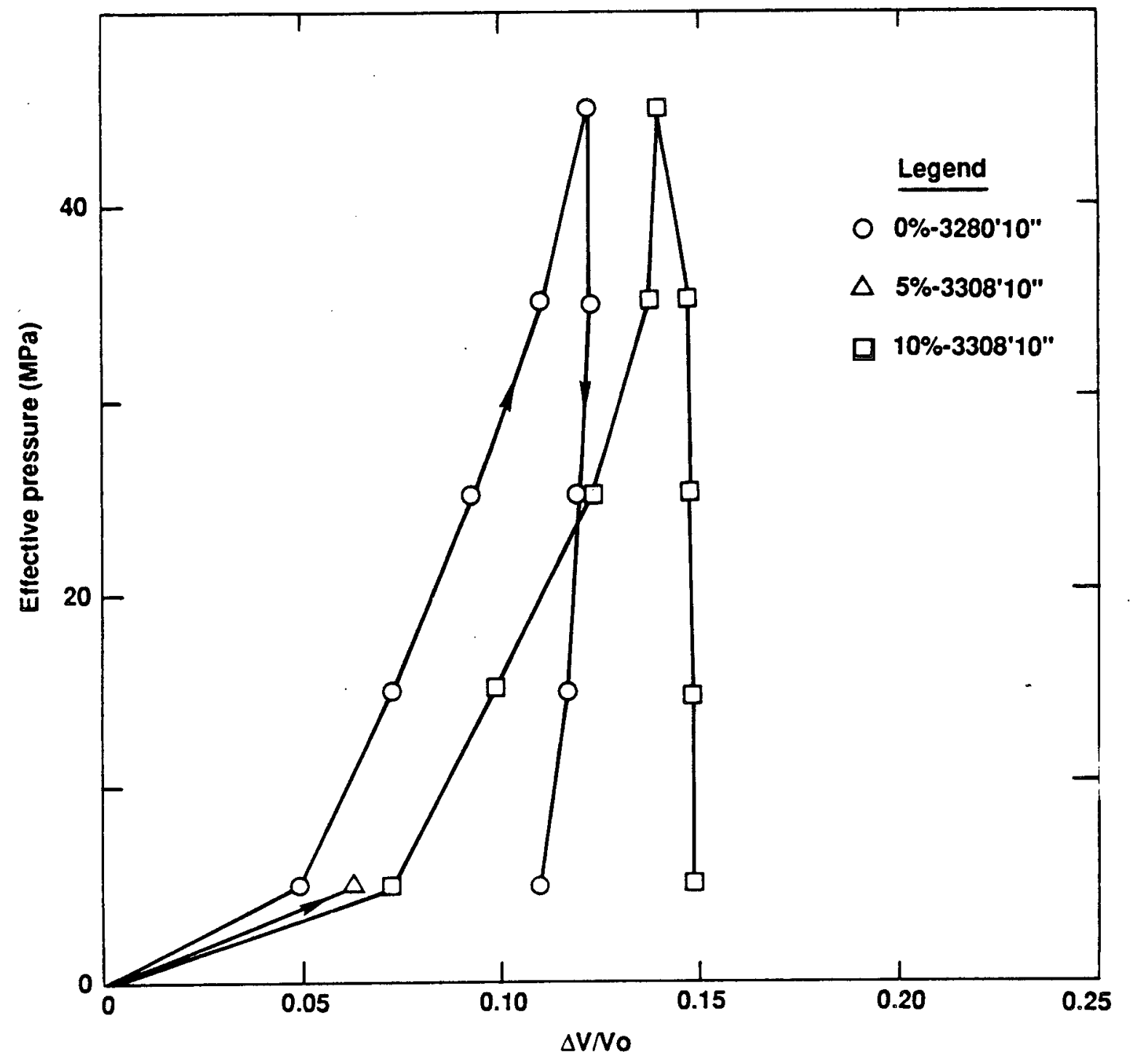

Figure 9. The PV data for undisturbed and disturbed oil-sand at $125^{\circ} \mathrm{C}$. 


\subsubsection{Undisturbed Shale: Pressure-Volume Behavior}

Pressure-volume (PV) behavior for undisturbed shale samples tested at effective stress to $45 \mathrm{MPa}$ and at temperatures of 23 and $125^{\circ} \mathrm{C}$ is shown in Fig. 10 and tabulated values are in Appendix $A$. Data for the sample tested at $23^{\circ} \mathrm{C}$ show that for $P_{E}$ lower than $2.5 \mathrm{MPa}$, the compressibility of the shale was below the resolution of the testing apparatus. As effective pressure was raised to 45 $\mathrm{MPa}$, the sample compacted linearly with increasing effective pressure; we calculated the bulk modulus to be $2100 \mathrm{MPa}$ for this pressure range (see Table 3). As effective pressure was lowered, the sample regained only about one-fourth of the volume lost, indicating that the increased effective pressure caused permanent compaction of pore space. The sample tested at $125^{\circ} \mathrm{C}$ experienced a volume strain of 0.05 as effective pressure was raised to $5 \mathrm{MPa}$. As effective pressure $P_{E}$ was increased from 5 to $45 \mathrm{MPa}$, this sample showed a slight increase in slope of the PV curve with increasing pressure. Calculation of bulk modulus (K) over the pressure range 25 to $45 \mathrm{MPa}$ indicates a value of approximately $1660 \mathrm{MPa}$, which is somewhat lower than the value of $\mathrm{K}$ calculated for the $23^{\circ} \mathrm{C}$ sample.

Comparison of results from the tests at 23 and $125^{\circ} \mathrm{C}$ indicates that the sample tested at $23^{\circ} \mathrm{C}$ compressed linearly with increasing effective pressure. The data also indicate that heating to $125^{\circ} \mathrm{C}$ caused mechanical disturbance and opened pore space and/or cracks in the friable shale sample. These cracks closed as effective pressure was raised above $5 \mathrm{MPa}$. More importantly, at effective pressures to $45 \mathrm{MPa}$, the bulk modulus of the heated sample was significantly less than that of the unheated sample, showing that the high temperature shale was more compressible. This might be due to changes in the viscosity and compressibility of the oil phase present in the shale or to other mechanisms such as changes in surface tension of liquid phases with temperature. Explanation of this behavior requires study beyond the scope of this report.

\subsubsection{Shale: Effect of Disturbance}

Results of PV tests on disturbed and undisturbed shale samples tested at $23^{\circ} \mathrm{C}$ are shown in Fig. 11. Here we define disturbed samples as those strained to 5 and $10 \%$ axial strain in unconfined traixial tests (see Section 3.2.2 and Appendix C). In these triaxial tests, both of the shale samples exhibited brittle or 


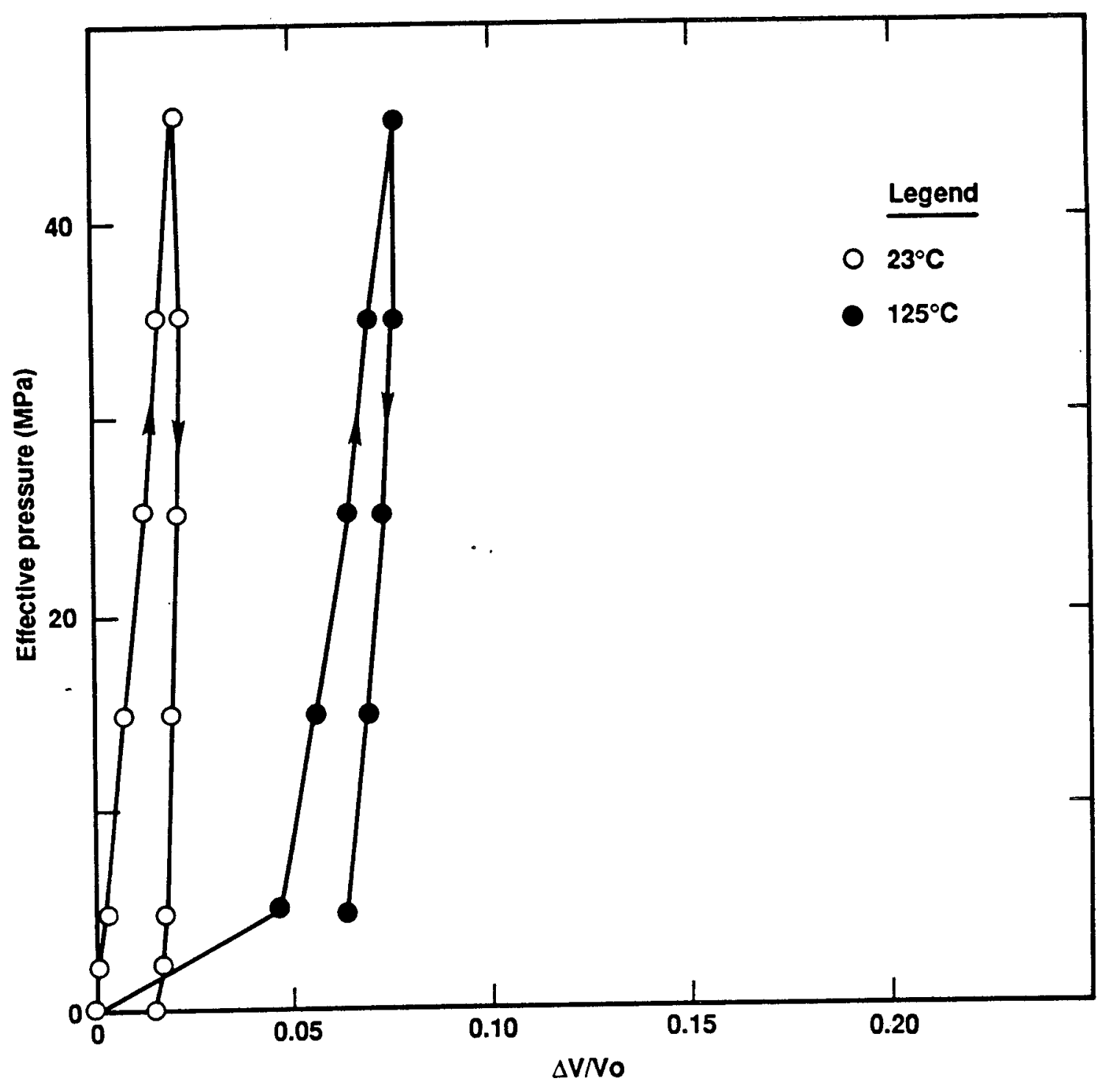

Figure 10. The PV behavior of undisturbed shale at 23 and $125^{\circ} \mathrm{C}$. 


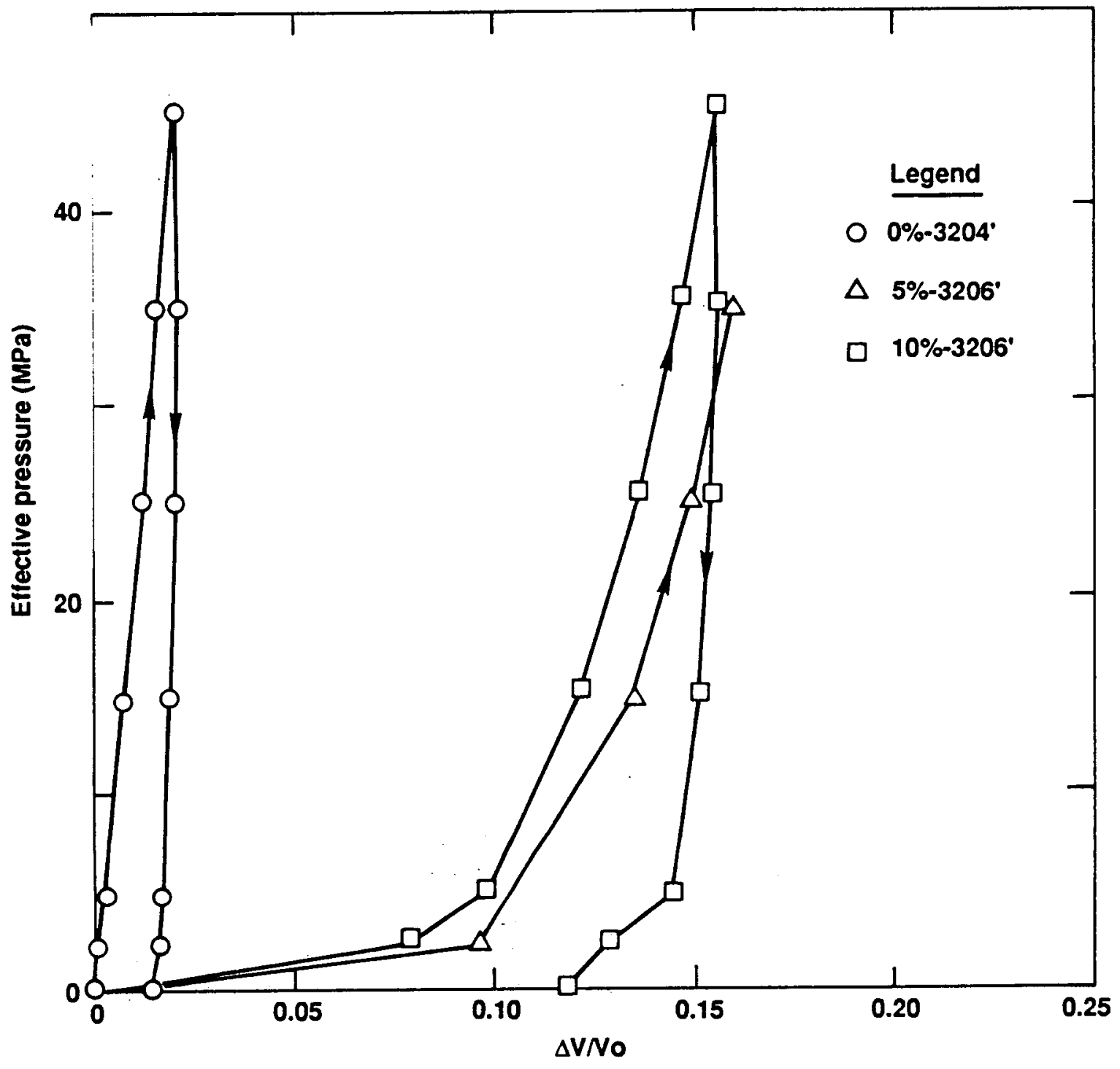

Figure 11. The PV data for undisturbed and disturbed shale at $23^{\circ} \mathrm{C}$. 
transitional behavior with strain-softening occurring at strains greater than 0.03. The PV data for both disturbed samples show that, as effective pressure was raised to $2.5 \mathrm{MPa}$, significant volume changes occurred. As effective pressure was increased from 2.5 to $45 \mathrm{MPa}$, both of the disturbed samples showed similar behavior and the 5\% sample was slightly more compressible than the $10 \%$ sample. This indicates that, as with the oil-sand samples, axial strain of $10 \%$ may introduce some permanent compaction into the samples. Summary data given. in Table 3 indicate that, at $23^{\circ} \mathrm{C}$, computed values of bulk modulus of the disturbed samples are approximately one-half of that for the undisturbed sample.

The PV data for undisturbed and disturbed shale samples tested at $125^{\circ} \mathrm{C}$ are plotted in Fig. 12; tabulated data are in Appendix $A$. These data show that, as effective pressure was raised to $5 \mathrm{MPa}$, there was little difference between the behavior of the disturbed and undisturbed samples because they all compacted about $5 \%$. As effective pressure was raised from 5 to $45 \mathrm{MPa}$, the $5 \%$ disturbed sample was somewhat more compressible than the undisturbed sample. However, the $10 \%$ sample continued to compact at a high rate as effective pressure was raised from 5 to $15 \mathrm{MPa}$. At effective pressures above $15 \mathrm{MPa}$, the behavior of all three samples was similar, which indicates that mechanical disturbance had less effect on shale samples at $125^{\circ} \mathrm{C}$ than at $23^{\circ} \mathrm{C}$. All of the shale samples tested at $125^{\circ} \mathrm{C}$ showed about $5 \%$ volume strain as effective pressure was raised to $5 \mathrm{MPa}$.

This is the only test of the series in which the $5 \%$ disturbed sample compacted less than the $10 \%$ disturbed sample and can be explained by considering the density of the samples (see Table 1). Sample 7 (5\%) had an anomalously low density of $1.84 \mathrm{~g} / \mathrm{cm}^{3}$ and was quite weak in unconfined axial compression (ultimate stress $=0.8 \mathrm{MPa}$ ). Sample $23(10 \%)$ had a higher density $\left(2.03 \mathrm{~g} / \mathrm{cm}^{3}\right.$ ) and was stronger in unconfined axial compression (ultimate stess $=8 \mathrm{MPa}$ ) and failed by brittle fracture. Our interpretation is that disturbance of sample 7 caused permanent compaction, but disturbance of sample 23 caused extensive cracking.

In summary, at $23^{\circ} \mathrm{C}$, mechanical disturbance of the samples significantly affected the PV behavior of shale at both low and high pressures. At the lower pressures, significant closure of cracks or fissures was evident, and at higher pressures, the bulk modulus was reduced by as much as a factor of 2 . Mechanical disturbance had less effect on the samples tested at $125^{\circ} \mathrm{C}$. At this 


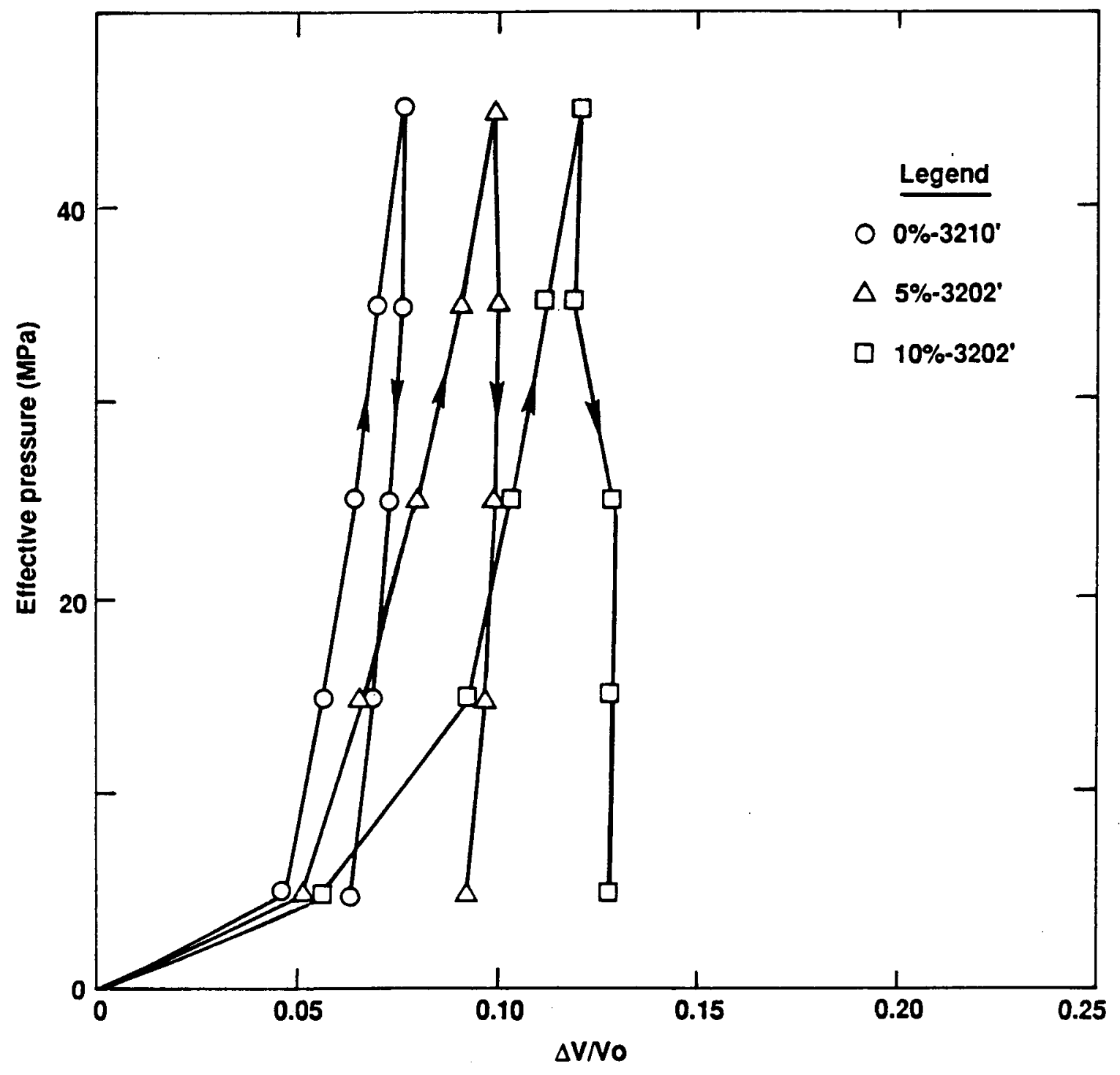

Figure 12. The PV data for undisturbed and disturbed shale at $125^{\circ} \mathrm{C}$. 
temperature, undisturbed and disturbed samples behaved alike as effective pressure was increased from 0 to $5 \mathrm{MPa}$. However, above $25 \mathrm{MPa}$, the bulk modulus of disturbed samples was lower than for the undisturbed sample. Moreover, these results indicate that, as pressure was raised from 25 to 45 $M P a$, the bulk modulus of the disturbed samples at both temperatures was 800-1200 MPa. Thus, for a disturbed sample, temperature had little effect on compressibility in this pressure range. These results also show that samples of both oil-sand and shale were not significantly disturbed by the coring, handling, and shipping activities that occurred prior to testing.

\subsection{TASK D.2: LABORATORY DETERMINATION OF PARAMETERS FOR MODEL SIMULATIONS:} TRIAXIAL TESTS

The objective of this task is to provide parameters for input to reservior behavior models. Work conducted on this task included triaxial tests on both oil-sand and shale at a series of temperatures and pressures. The stress-strain data determined from these tests was used to determine

Mohr-Coulomb failure envelopes for these materials at temperatures of 23,125 , and $250^{\circ} \mathrm{C}$.

In all, we conducted more than 34 triaxial tests for this task. During all tests, pore fluid pressure was maintained at one-half the confining fluid pressure.

\section{2 .1 0il-Sand Triaxial Tests}

Oil-sand samples were tested at 23,125 , and $250^{\circ} \mathrm{C}$ and at confining pressures ranging from 0.1 to $300 \mathrm{MPa}$. Stress-strain plots for tests at $23^{\circ} \mathrm{C}$ are shown in Figs. B-1 to B-5 in Appendix B. Tabulated data for each test are also contained in Appendix $B$. Results are shown as axial stress $\left(\sigma_{1}-\sigma_{3}\right)$ vs. axial strain. A typical stress-strain plot is shown in Fig. 13. This plot shows the various regions of the stress-strain curve, including an initial elastic compression, peak or ultimate stress, and residual stress after failure. The data for two unconfined tests are shown in Fig. 14. These samples behaved in a strain-hardening manner, and axial compressive strength increased from approximately $0.5 \mathrm{MPa}$ at 0.007 strain to approximately $1.75 \mathrm{MPa}$ at 0.08 strain. The effect of raising effective 


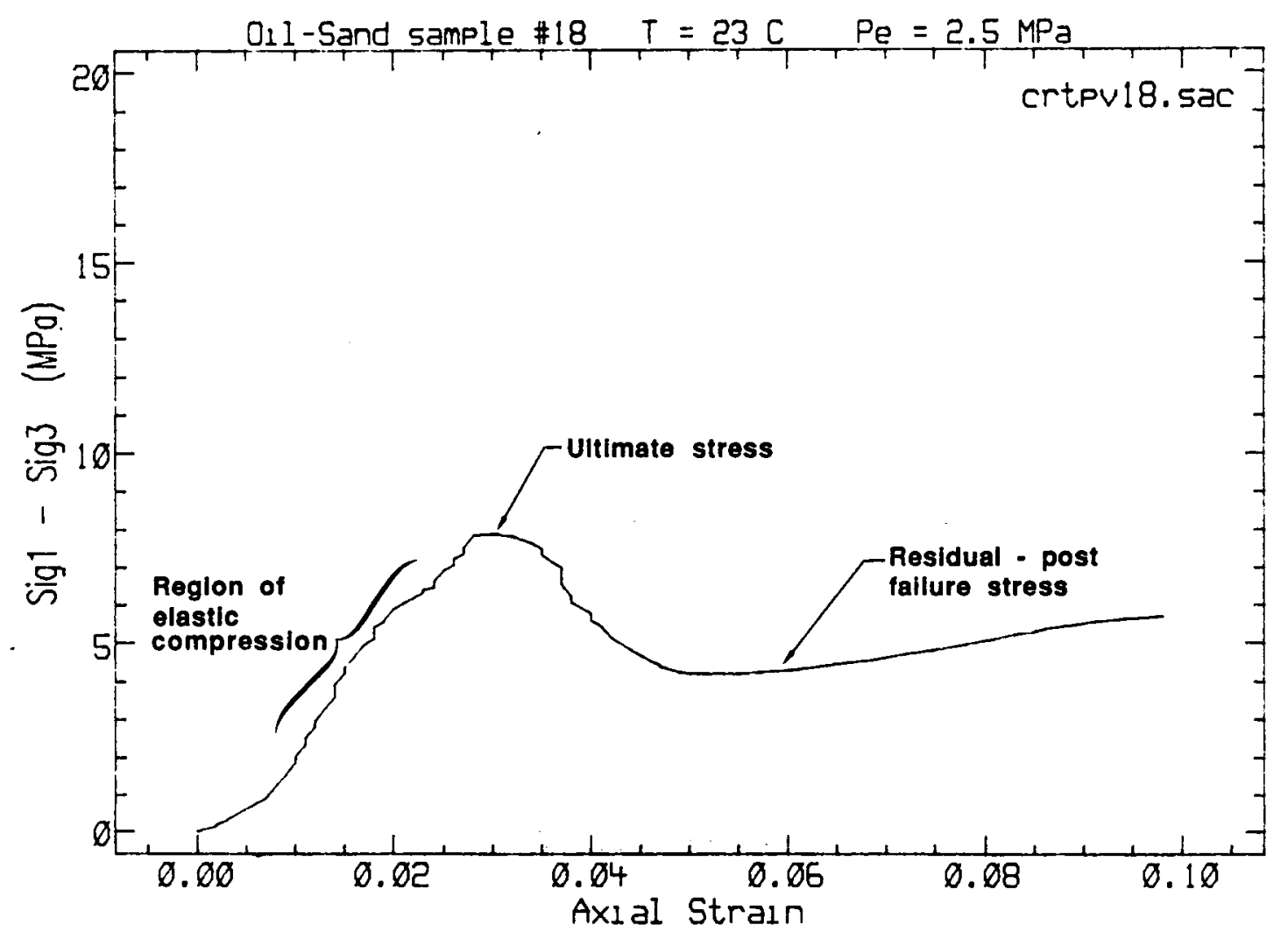

Figure 13. Stress-strain data for oil-sand at $23^{\circ} \mathrm{C}$ and pressure of $5 \mathrm{MPa}$. 


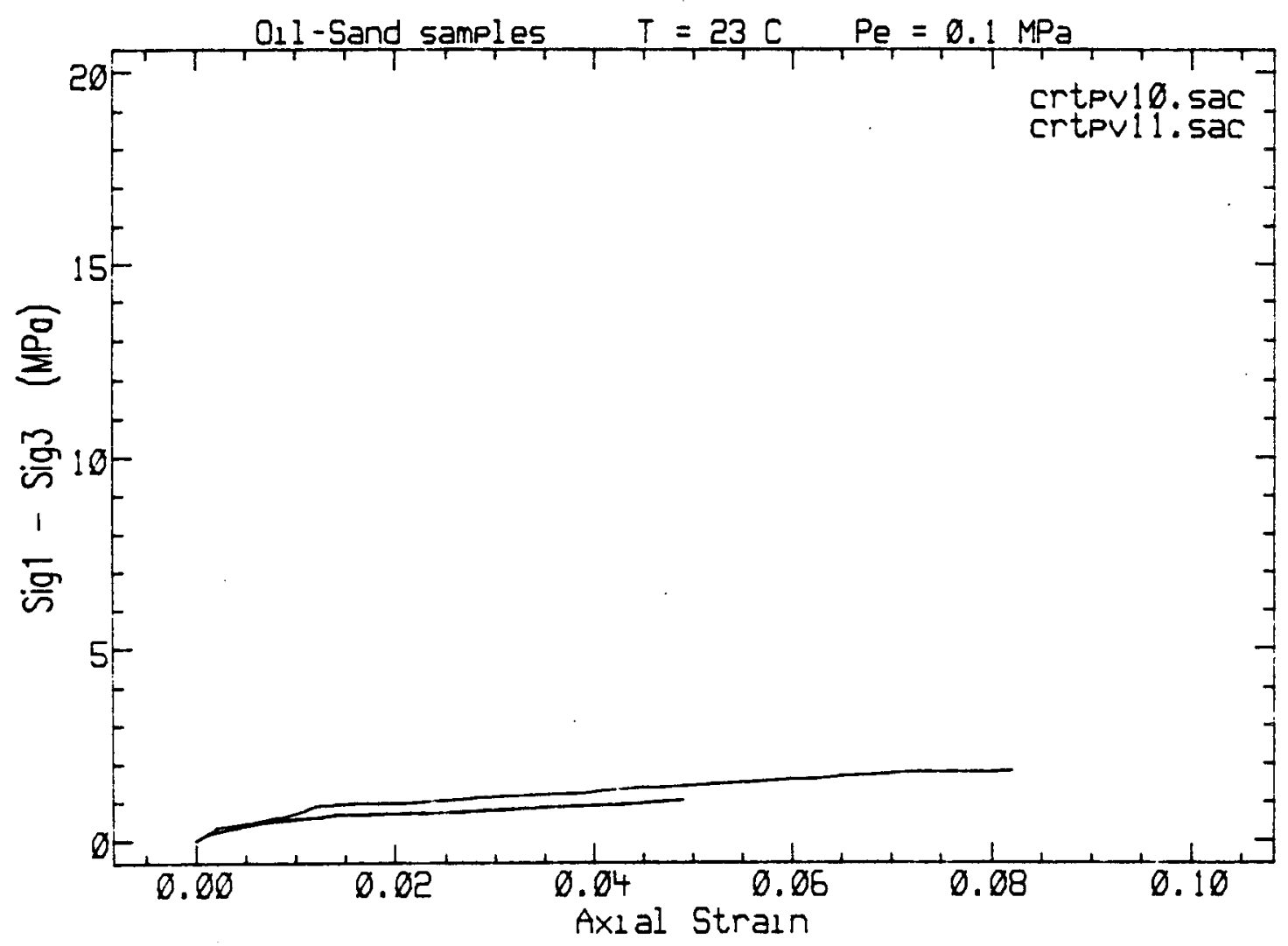

Figure 14. Stress-strain data for unconfined oil-sand at $23^{\circ} \mathrm{C}$. 
pressure to values in the range 2.5 to $25 \mathrm{MPa}$ is shown in Fig. 15. As expected, samples tested at the highest effective pressures were strongest. However, these data show that, as effective pressure was increased in the range 2.5 to $10 \mathrm{MPa}$, compressive strength of the oil-sand remained relatively constant. The results indicate that the material undergoes a brittle-to-ductile transition in this pressure range because the behavior at $P_{E}=2.5 \mathrm{MPa}$ is brittle, but clearly ductile behavior is shown at $P_{E}=10$ $\mathrm{MPa}$. Note that, at strains greater than about 0.04 , all samples show strain-hardening behavior.

These results show that, although the oil-sand was unconsolidated at unconfined conditions when confining pressure was applied, some failure occurred via a faulting mechanism. This is illustrated by the test of sample 18 (Figure B-2), which shows significant loss of strength after failure and by the test of sample 17 (Figure B-3). The overall behavior of sample 17 suggests failure by ductile flow and strain-hardening. However, at least three failure events occurred during the test in which the strength dropped by a few MPa. This suggests that faulting occurred within the confined samples of oil-sand at $23^{\circ} \mathrm{C}$.

Results of triaxial tests on oil-sand at $125^{\circ} \mathrm{C}$ and at various confining pressures are presented in Figures 8-6 to B-11. Tabulated data for these tests are ncluded in Appendix B. Again, data are plotted as $\sigma_{1}-\sigma_{3}$ vs. axial strain. Unconfined samples (Fig. 16) have an ultimate strength of approximately $0.25 \mathrm{MPa}$ and show strain-softening behavior. Stress-strain curves for samples tested at effective pressures from 5 to $150 \mathrm{MPa}$ are shown in Fig. 17. As effective pressure was raised to $150 \mathrm{MPa}\left(T=125^{\circ} \mathrm{C}\right)$, compressive strength generally increased with confining pressure and values of $\left(\sigma_{1}-\sigma_{3}\right)$ were 7 to $35 \mathrm{MPa}$. Samples tested at effective pressures of 5-25 MPa deformed by ductile flow and showed strain-hardening behavior. This indicated that, at these pressure and temperature conditions, pore fluid drained from the samples during deformation and strength was increased due to increased grain-to-grain contact. The oil-sand sample tested at an effective pressure of $150 \mathrm{MPa}$ exhibited elastic behavior at strains less than or equal to 0.01 and yielded by ductile flow at strains greater than 0.02 . The ultimate stress for this sample was $32 \mathrm{MPa}$.

0il-sand samples were also tested at $250^{\circ} \mathrm{C}$ under unconfined conditions. Data for these tests are plotted in Figures B-12 and tabulated data are presented in Appendix $B$. The samples in these tests failed at an axial 


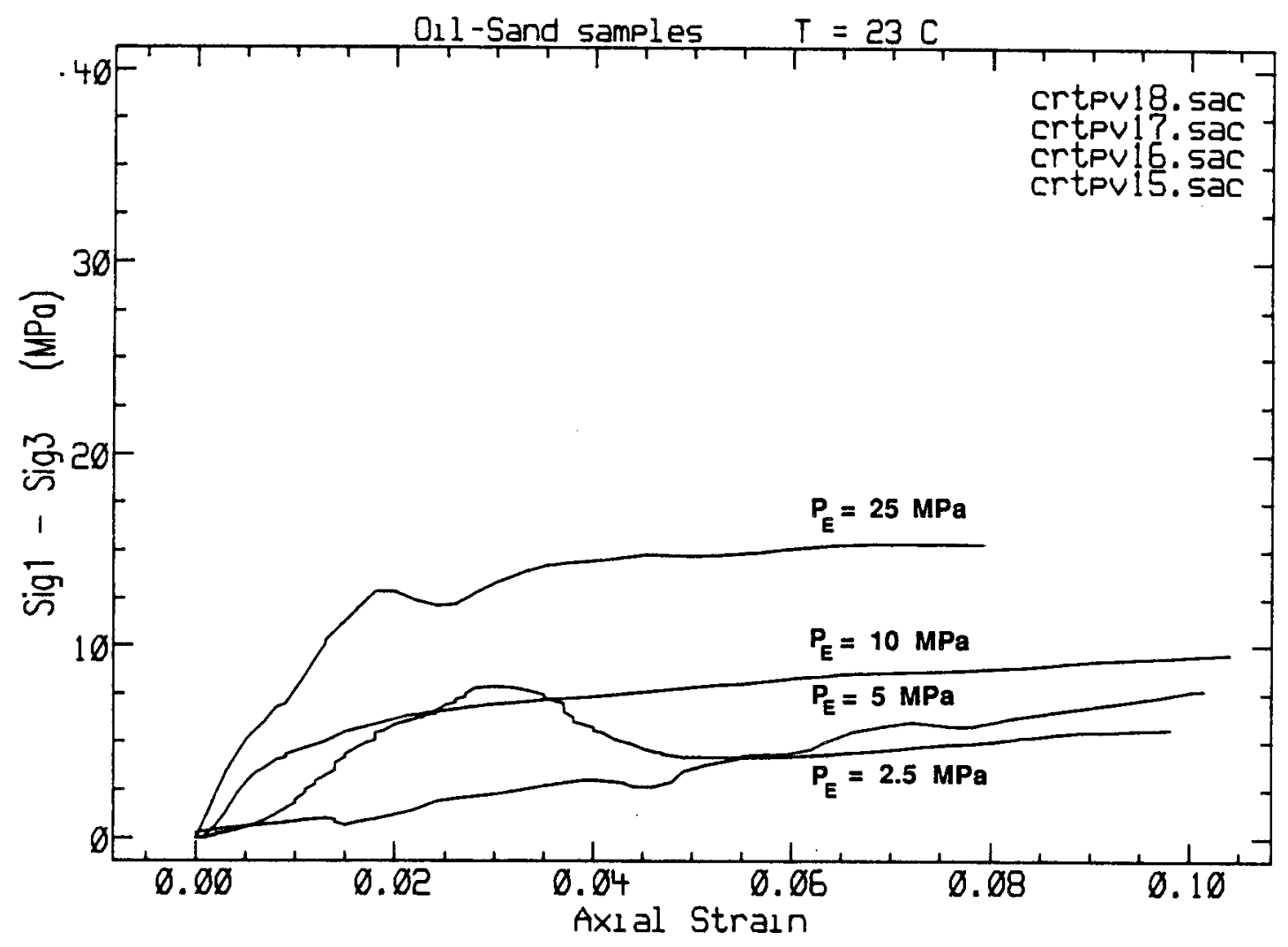

Figure 15. Stress-strain curves for oil-sand samples tested at $23^{\circ} \mathrm{C}$ and effective pressure to $25 \mathrm{MPa}$. 


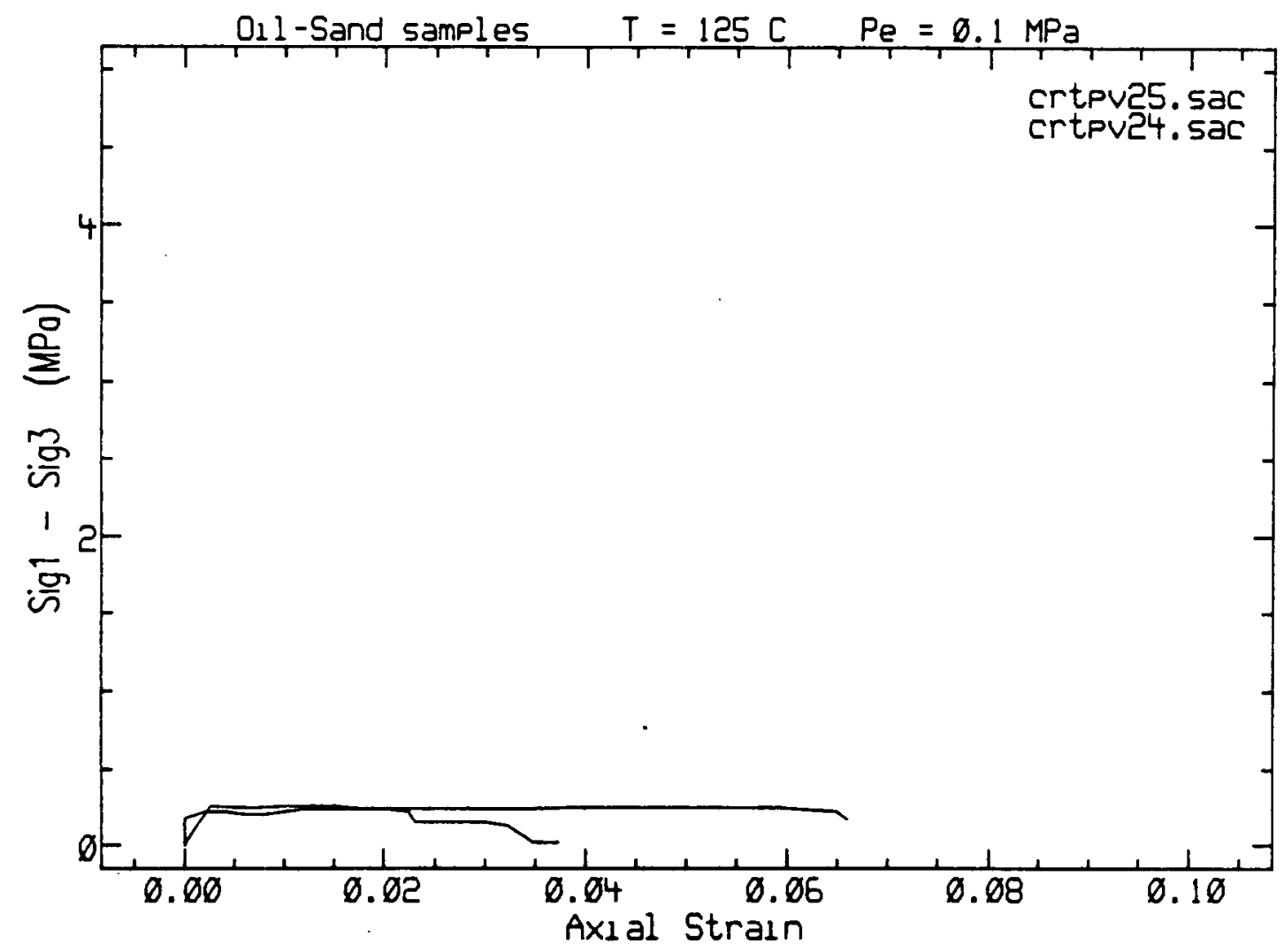

Figure 16. Stress-strain plots for unconfined oil-sand samples at $125^{\circ} \mathrm{C}$. 


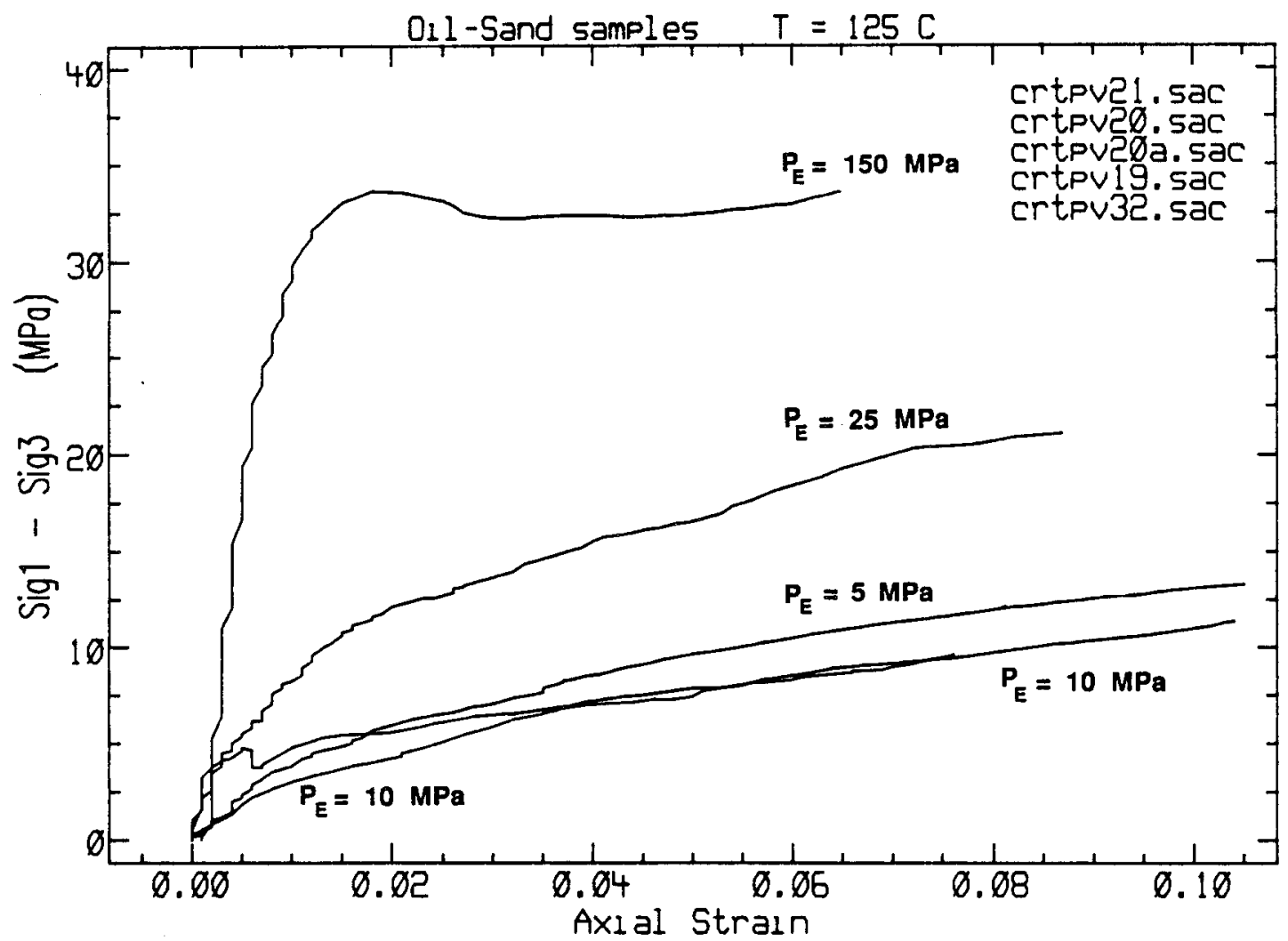

Figure 17. Stress-strain plots for oil-sand samples tested at $125^{\circ} \mathrm{C}$. 
stress of approxomately $1 \mathrm{MPa}$, which is similar to the value measured for unconfined oil-sand at $23^{\circ} \mathrm{C}$. Attempts to test oil-sand at $250^{\circ} \mathrm{C}$ and at elevated effective pressures were unsuccessful due to jacket failures.

Mohr-Coulomb failure envelopes for the oil-sand samples at 23 and $125^{\circ} \mathrm{C}$ were constructed as follows (Fig. 18). First, a line was fitted (graphically) to the ductile (plastic) portion of the stress-strain curves for each oil-sand sample, and the value of $\sigma_{1}-\sigma_{3}$ at $4 \%$ strain along this line was read from the graph. For these tests,

so $\sigma_{1}(4 \%)$ was computed as

$$
\sigma_{2}=\sigma_{3}=P_{E}
$$

$$
\sigma_{1}(4 \%)=\left(\sigma_{1}-\sigma_{3}\right)_{4 \%}+P_{E} .
$$

The strength at $4 \%$ was chosen because all samples displayed ductile behavior at this strain. values of $\sigma_{1}-\sigma_{3}$ at $4 \%$ strain are tabulated in Table 4.

The Mohr circles show that raising the temperature from 23 to $125^{\circ} \mathrm{C}$ had very little effect on the compressive or shear strength of oil-sand. At effective stress below $35 \mathrm{MPa}$, the angle of internal friction is approximately 15 degrees. (Note that data for sample 21 do not fit this trend and were omitted from the plot. This sample was unusually strong.)

The above results show that, by increasing temperature from 23 to $125^{\circ} \mathrm{C}$, the compressive behavior of oil-sand was affected in the following ways. First, the unconfined compressive strength decreased with increasing temperature, from between 1 to $2 \mathrm{MPa}$ at $23^{\circ} \mathrm{C}$ to $0.25 \mathrm{MPa}$ at $125^{\circ} \mathrm{C}$. The samples are stronger at $23^{\circ} \mathrm{C}$, possibly because at this temperature the oil in the pore was quite viscous and helped to bond the sample together. At $125^{\circ} \mathrm{C}$, the oil viscosity was lower and provided less bonding, which allowed the sample to split more easily. Results of confined tests show that at both temperatures compressive strength increased as effective pressure was raised. Samples tested at equivalent pressures had similar strengths, and most of the samples strain-hardened throughout the test. However, for samples tested at equivalent pressures, those tested at $23^{\circ} \mathrm{C}$ were slightly stronger at strains less than 0.03 , but the plastic modulus (rate of increasing strength with increasing strain) was higher for samples tested at $125^{\circ} \mathrm{C}$. 


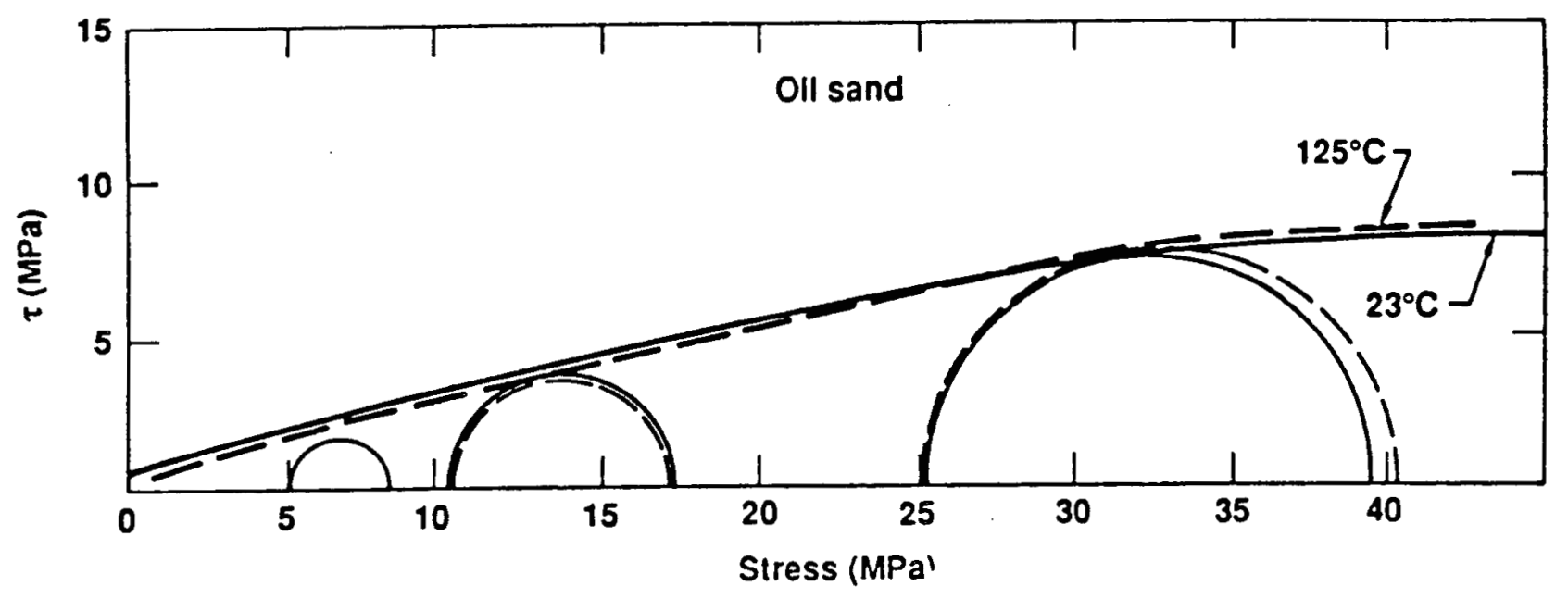

Figure 18. Mohr circles for oil-sand showing results from tests at 23 and $125^{\circ} \mathrm{C}$. 
Table 4. Summary data for oil-sand.

\begin{tabular}{|c|c|c|c|c|c|c|c|c|}
\hline & & Confining & Effective & Test & Elast ic & Plastic & $\Delta V / V_{0}$ & $\sigma_{1}-\sigma_{3}$ \\
\hline No. & $(\mathrm{ft})$ & (MPa) & $\left(P_{E}=\sigma_{3}\right)$ & $\left({ }^{\circ} \mathrm{C}\right)$ & (MPa) & (MPa) & & $\begin{array}{l}(\mathrm{MPa} \varepsilon=4 \%) \\
(\mathrm{Pa})\end{array}$ \\
\hline
\end{tabular}

$\begin{array}{lllllllll}10 & 3279 & 0.1 & -- & 23 & 67 & 16 & -- & 1.3 \\ 11 & 3279 & 0.1 & -- & 23 & 35 & 11 & -. & 0.94 \\ 18 & 3308 & 5 & 2.5 & 23 & 410 & 39 & .032 & 7.9^{*} \\ 17 & 3307 & 10 & 5 & 23 & -- & 62 & 0.068 & 3 \\ 16 & 3308 & 20 & 10 & 23 & 741 & 36 & 0.071 & 7.4 \\ 15 & 3307 & 50 & 25 & 23 & 810 & 31 & 0.062\end{array}$

\begin{tabular}{|c|c|c|c|c|c|c|c|c|}
\hline 24 & 3308 & 0.1 & -- & 125 & 57 & 0.23 & -- & 0.3 \\
\hline 25 & 3308 & 0.1 & -- & 125 & 133 & -- & -- & -- \\
\hline 21 & 3308 & 10 & 5 & 125 & -- & 71 & 0.042 & 8.5 \\
\hline 20 & 3308 & 20 & 10 & 125 & 3750 & 66 & 0.060 & 7 \\
\hline $20 A$ & 3307 & 20 & 10 & 125 & -- & 52 & 0.132 & 7 \\
\hline 19 & 3307 & 50 & 25 & 125 & -- & 156 & 0.114 & 15.5 \\
\hline 32 & 3280 & 300 & 150 & 125 & 4000 & 15 & 0.081 & 32 \\
\hline 30 & 3308 & 0.1 & -- & 250 & -- & 15 & -- & 1.2 \\
\hline 31 & 3308 & 0.1 & -- & 250 & -. & - & - & 1.6 \\
\hline
\end{tabular}


The strain-hardening behavior of the samples can be explained by increased grain-to-grain contact as strain increased, which is caused by draining of pore fluid during the test. The volume of fluid expelled during each test, normalized to the volume of the sample, is listed in Table 4. Fluid was expelled during all tests on oil-sand, and, generally, more fluid was expelled during tests at $125^{\circ} \mathrm{C}$. As the pore fluid was expelled, porosity and void ratio decreased and grain-to-grain contact increased. It is interesting to note that the stress-strain curves for the $125^{\circ} \mathrm{C}$ tests are smoother in character and do not contain as many "faulting" events.

In summary, raising the temperature from 23 to $125^{\circ} \mathrm{C}$ did not have a major effect on the compressive strength of oil-sand. The compressive strength seems to be controlled by pore fluid drainage from the material as axial compression was applied. The oil-sand had very little matrix strength; as pore fluid was expelled, porosity and void ratio decreased, density increased, and grain-to-grain contact increased. Pore fluid drainage was somewhat enhanced at $125^{\circ} \mathrm{C}$ by both the decreasing viscosity of the petroleum and the mechanical disturbance caused by heating (see PV results in Section 3.1.1). 0il-sand samples tested at $125^{\circ} \mathrm{C}$ strain-hardened at a slightly faster rate than samples tested at $23^{\circ} \mathrm{C}$.

\subsubsection{Shale}

Samples of the shale formation that overlies the oil-sand were also tested at triaxial conditions at temperatures of 23,125 , and $250^{\circ} \mathrm{C}$ and at confining pressures to $300 \mathrm{MPa}$. Tabulated data for these tests are presented in Appendix $C$, along with a stress-strain plot for each sample. Data for two unconfined samples tested at $23^{\circ} \mathrm{C}$ are shown in Fig. 19. Each sample failed by brittle fracture at a strain of 0.025 or less. Values of ultimate stress were 5.7 and $5.4 \mathrm{MPa}$. Both samples had significant residual strength at strains greater than 0.04. Data for samples tested at effective pressures 1-5 MPa are shown in Fig. 20. These samples failed in a transitional mode with ultimate stress of 7 to 12 MPa. Samples tested at effective pressures 10-150 MPa are shown in Fig. 21. These samples all failed in a ductile mode, and all showed strain-hardening at strains greater than 0.03 . Figure 21 shows that at $23^{\circ} \mathrm{C}$ raising effective pressure above $25 \mathrm{MPa}$ had little effect on the compressive strength of the shale. 


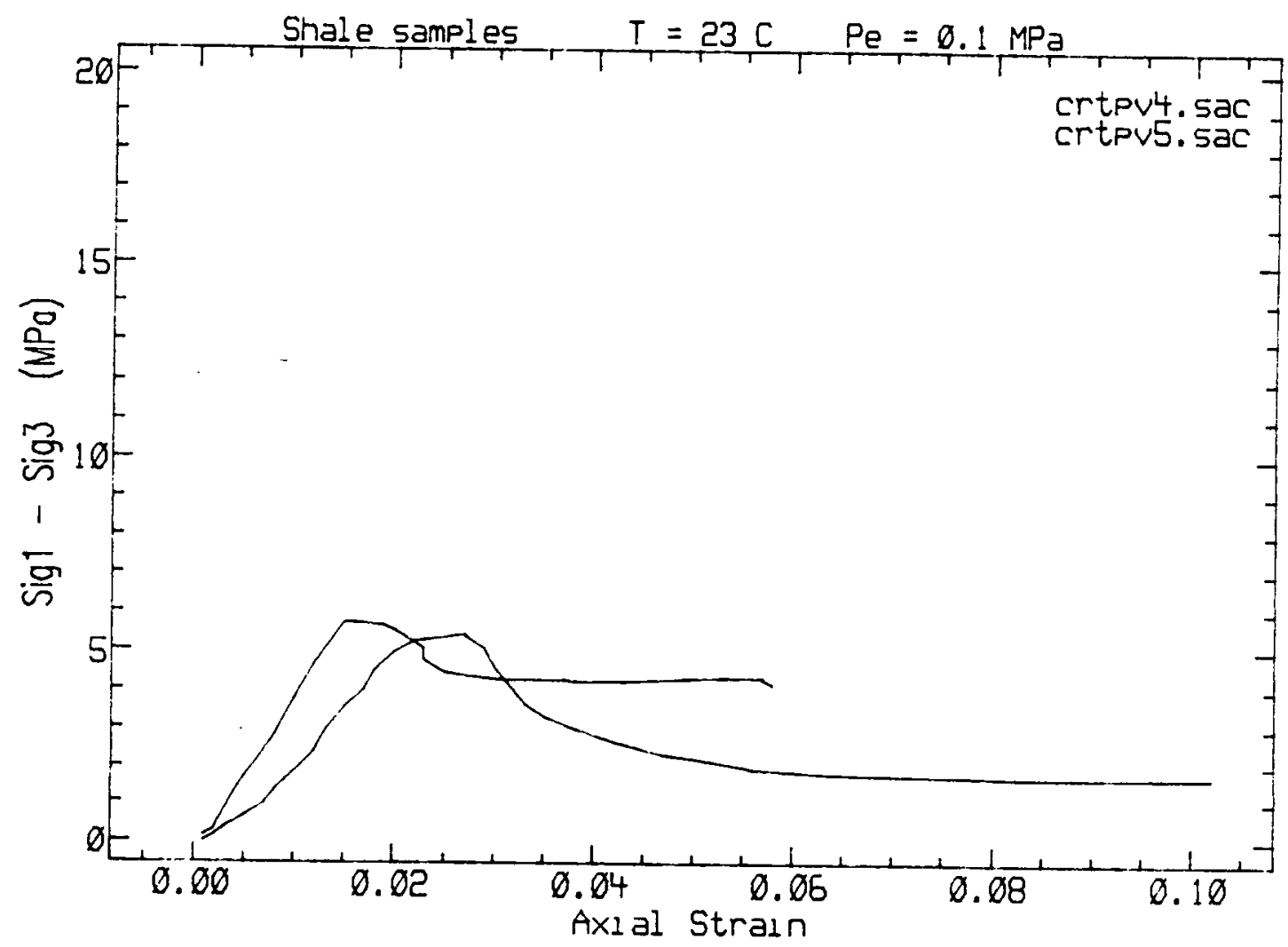

Figure 19. Stress-strain behavior for unconfined shale samples tested at $23^{\circ} \mathrm{C}$. 


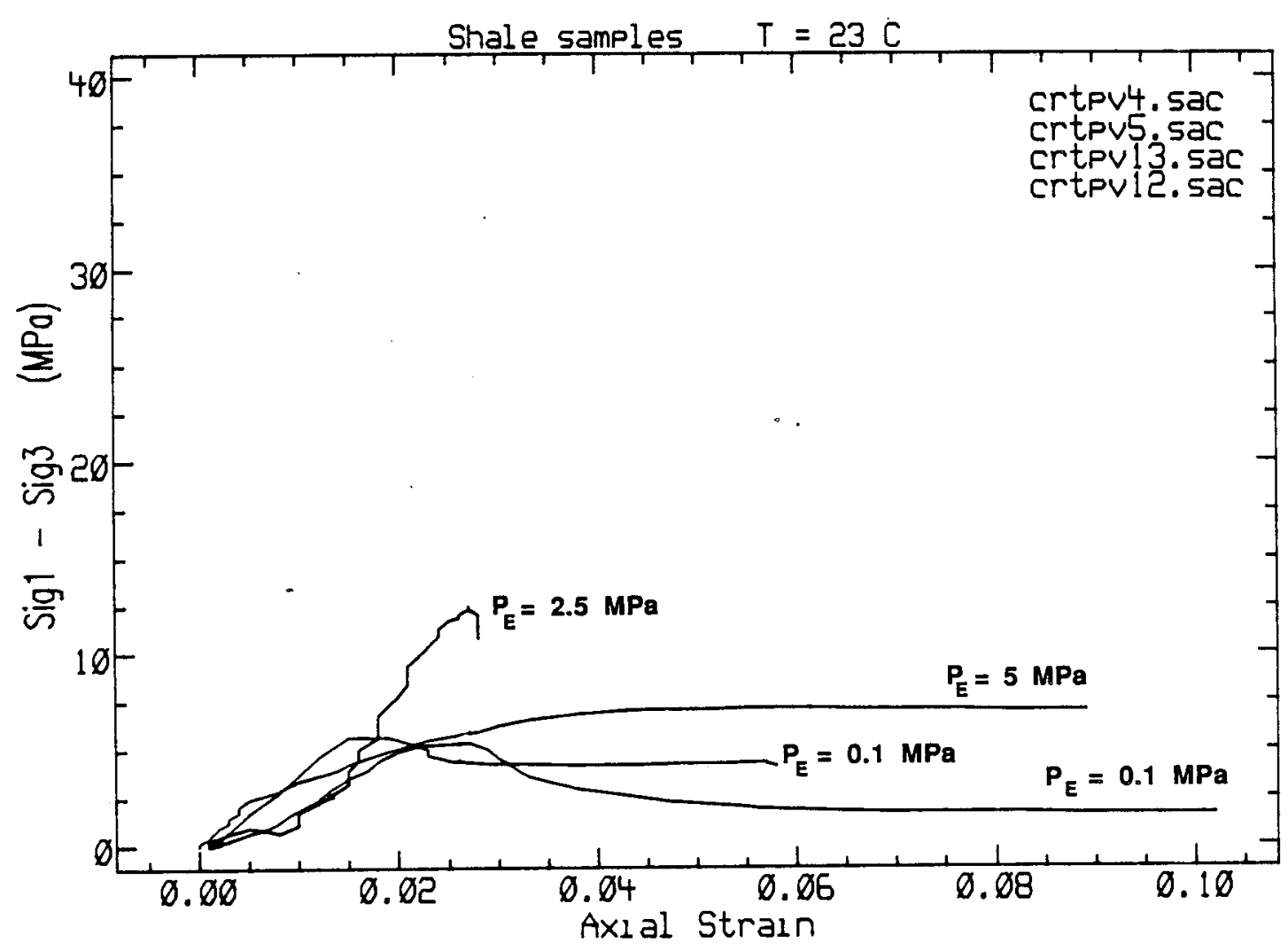

Figure 20. Stress-strain behavior for shale samples at effective pressures of $1,2.5$, and $5 \mathrm{MPa}$. 


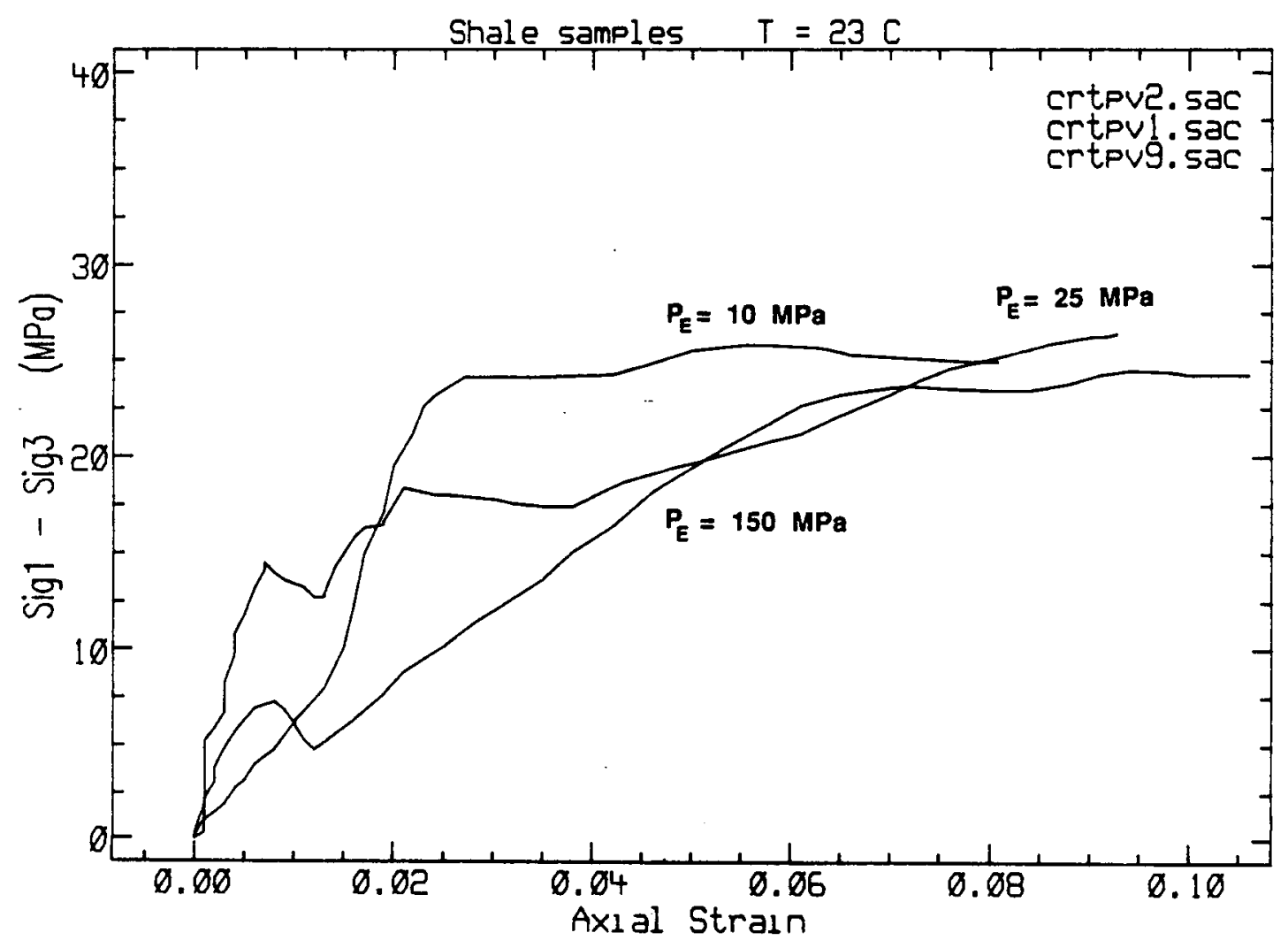

Figure 21. Stress-strain behavior for shale samples tested at $P_{E}=10$ to $150 \mathrm{MPa}$. 
The Mohr circles for shale tested at $23^{\circ} \mathrm{C}$ are shown in Fig. 22 . Using the classical failure analysis, we found that the shale had a friction angle of 35 degrees at stress levels less than $20 \mathrm{MPa}$. At pressures above $25 \mathrm{MPa}$, compressive stress had little effect on the shear stress; that is, maximum shear stress remained constant at approximately $12 \mathrm{MPa}$ as compressive stress was increased.

The effect of increased effective pressure on shale at a temperature of $125^{\circ} \mathrm{C}$ is shown in Figs. C-8 to $\mathrm{C}-14$ in Appendix C. Unconfined samples (Figs. $\mathrm{C}-8,9$ ) showed failure by brittle fracture with an ultimate strength of $0.9 \mathrm{MPa}$ at a strain of 0.04. Samples tested at effective pressures 5-150 MPa are shown in Fig. 23. Failure strength increased with increasing pressure, and all samples yielded at strains in the range of 1 to $4 \%$.

Monr circles for samples tested at $125^{\circ} \mathrm{C}$ are plotted in Fig. 24. This plot indicates that, at pressures less than $35 \mathrm{MPa}$, the shale had a friction angle in the range of 12 to 18 degrees.

Shale samples were also tested at $250^{\circ} \mathrm{C}$ and at pressures of 0.1 and 300 $\mathrm{MPa}$. Results are presented in Appendix $\mathrm{C}$ as stress-strain plots and as tabulated data. Data for these tests show that the unconfined samples failed by brittle fracture and had ultimate stress values similar to the unconfined samples tested at 23 and $125^{\circ} \mathrm{C}$. One sample tested at $P_{E}=150 \mathrm{MPa}$ failed by ductile flow, and its ultimate strength of $74 \mathrm{MPa}$ was the highest of all the shale samples. Values of elastic modulus for these samples are listed in Table 5. The moduli for these shale samples are quite variable, but they generally increase with increased effective pressure.

The Mohr circles for shale tested at 23,125 , and $250^{\circ} \mathrm{C}$ are plotted in Fig. 25. This plot clearly shows that, at an effective pressure of $150 \mathrm{MPa}$, the shear strength of the shale at $250^{\circ} \mathrm{C}$ was approximately twice that at $23^{\circ} \mathrm{C}$. This plot also shows that, at effective stresses greater than $25 \mathrm{MPa}$, the angle of friction for the shale increased with increasing temperature from approximately 0 degrees for samples at $23^{\circ} \mathrm{C}$, to between 9 and 11 degrees. for samples at $250^{\circ} \mathrm{C}$. However, at pressures less than $25 \mathrm{MPa}$, the shale was strongest at $23^{\circ} \mathrm{C}$.

One possible interpretation of these data is that, as shown in Section 3.1.3, the shale was more compressible at the higher temperatures. Consequently at the higher temperatures, the sample was compacted by the 


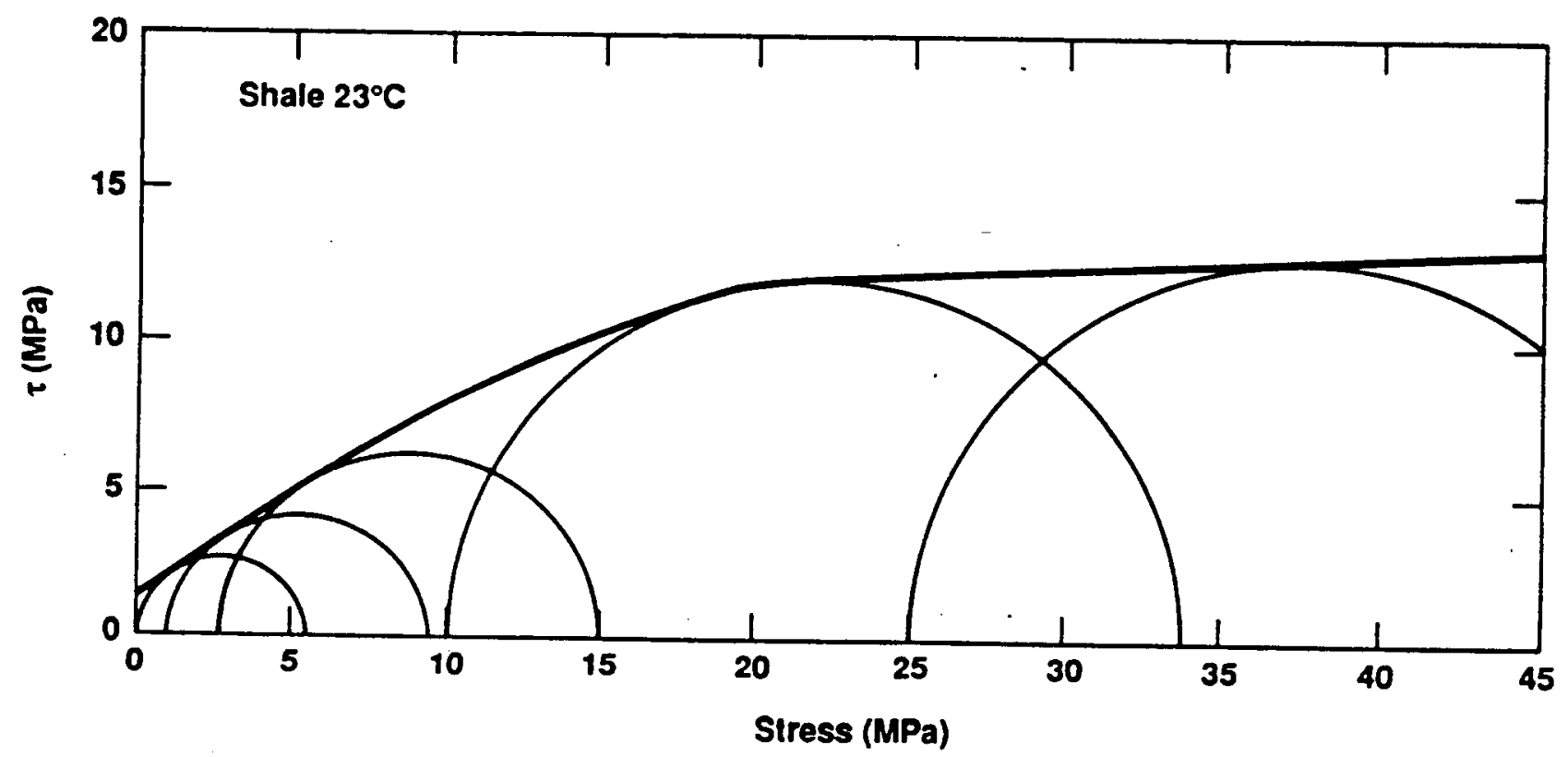

Figure 22. Mohr circles for shale tested at $23^{\circ} \mathrm{C}$. 


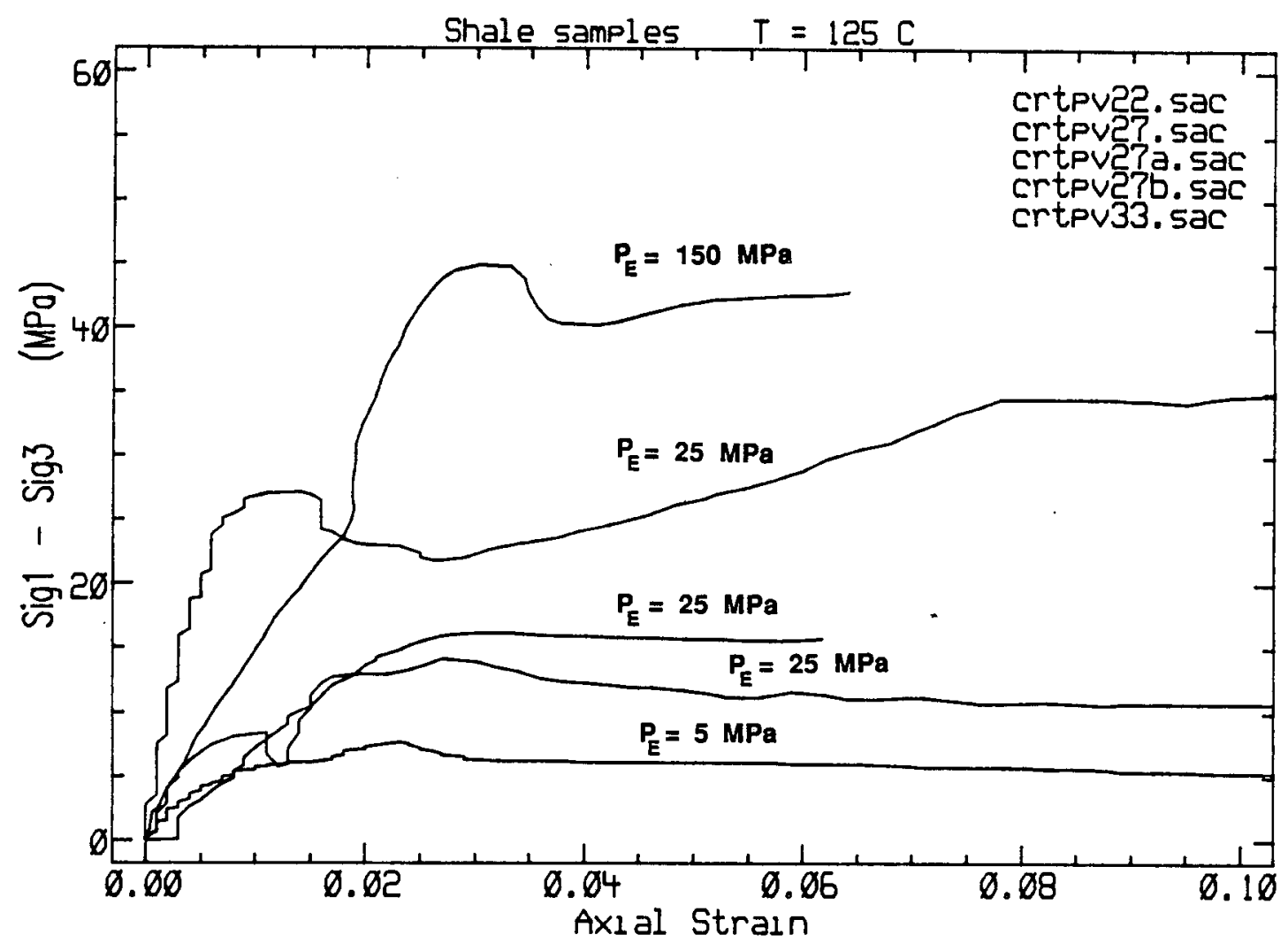

Figure 23. Stress-strain for shale at $125^{\circ} \mathrm{C}, \mathrm{P}_{\mathrm{E}}=5-150 \mathrm{MPa}$. 


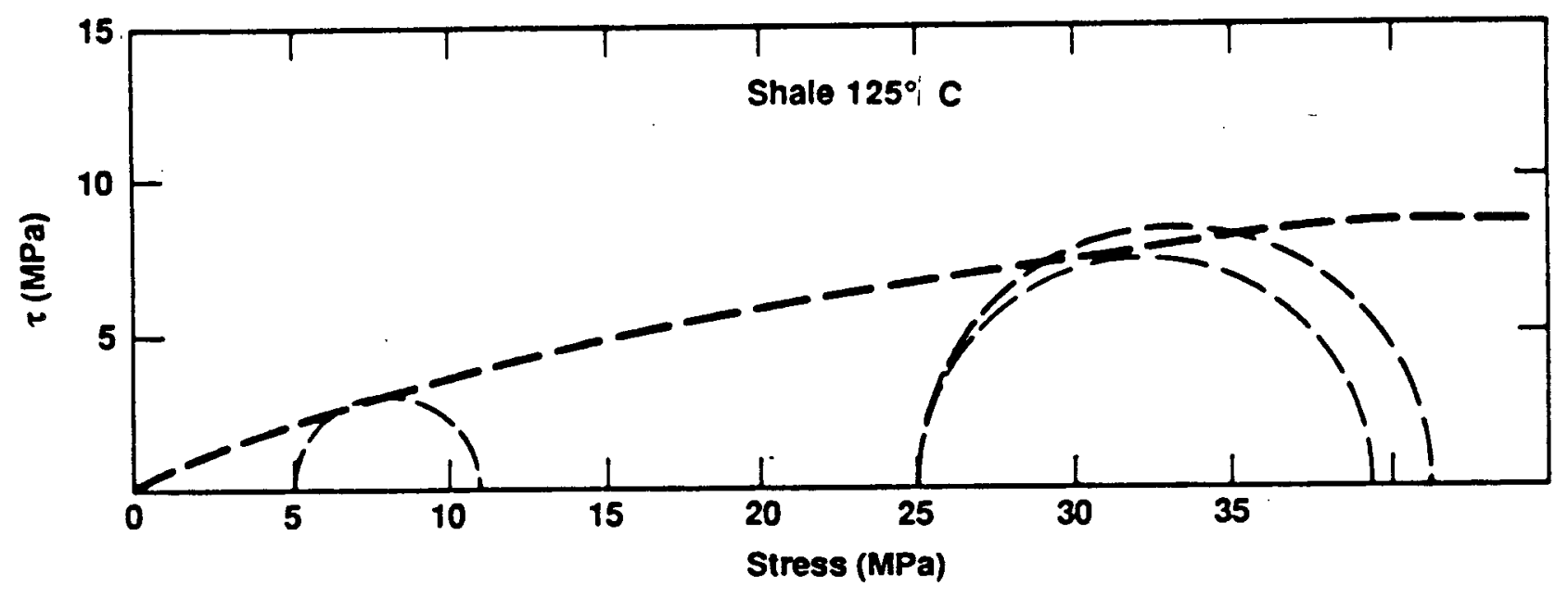

Figure 24. Mohr circles for shale at $125^{\circ} \mathrm{C}$. 
Table 5. Summary data of shale.

Confining Effective Temperature Elastic Ultimate

Sample Depth pressure pressure

modulus stress

No. $(\mathrm{ft})(\mathrm{MPa}) \quad(\mathrm{MPa}) \quad\left({ }^{\circ} \mathrm{C}\right)$

$\left(\sigma_{1}-\sigma_{3}\right)$ @ $4 \mathrm{E}$

(MPa)

(MPa)

\begin{tabular}{|c|c|c|c|c|c|c|}
\hline 5 & 3206 & 0.1 & -- & 23 & 314 & 5.4 \\
\hline 4 & 3206 & 0.1 & -- & 23 & 381 & 5.7 \\
\hline 14 & 3210 & 2 & 1 & 23 & 268 & 8.2 \\
\hline 13 & 3206 & 5 & 2.5 & 23 & 857 & 12 \\
\hline 12 & 3206 & 10 & 5 & 23 & -- & 7 \\
\hline 2 & 3204 & 20 & 10 & 23 & 1622 & 23 \\
\hline 1 & 3204 & 50 & 25 & 23 & 2500 & 18 \\
\hline 9 & 3204 & 300 & 150 & 23 & 391 & 24 \\
\hline 7 & 3202 & 0.1 & -- & 125 & -- & 0.86 \\
\hline 23 & 3202 & 0.1 & -- & 125 & 750 & 9 \\
\hline 22 & 3210 & 10 & 5 & 125 & -- & 7.6 \\
\hline 26 & 3202 & 20 & .10 & 125 & -- & -- \\
\hline 27 & 3211 & 50 & 25 & 125 & 3958 & 27 \\
\hline $17 A$ & 3211 & 50 & 25 & 125 & 1850 & 14 \\
\hline $27 B$ & 3202 & 50 & 25 & 125 & 694 & 16 \\
\hline 33 & 3210 & 300 & 150 & 125 & 1695 & 45 \\
\hline 28 & 3202 & 0.1 & -- & 250 & 230 & 6.3 \\
\hline 29 & 3202 & 0.1 & -- & 250 & 490 & 12.3 \\
\hline 34 & 3211 & 300 & 150 & 250 & 3550 & 74 \\
\hline
\end{tabular}




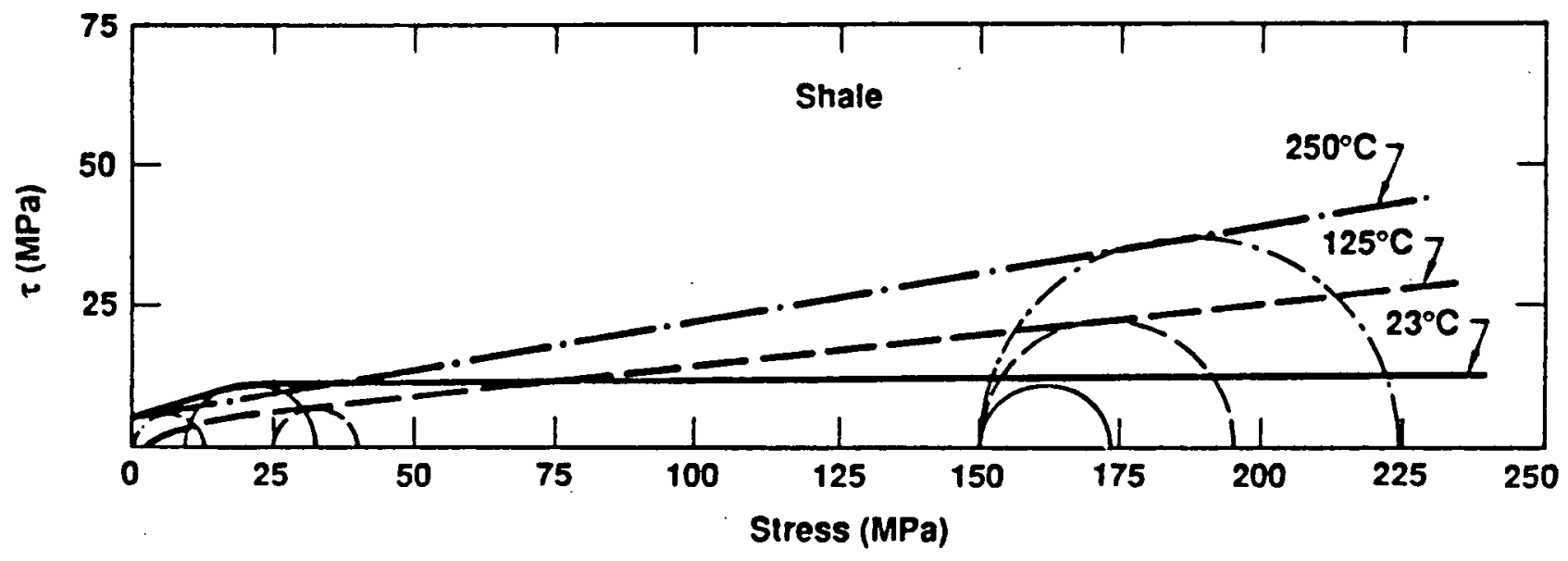

Figure 25. Mohr circles for shale at 23, 125 , and $250^{\circ} \mathrm{C}$. 
initial hydrostatic loading imposed before the axial stress was applied. Thus, material tested at higher temperatures had higher density, lower porosity, and a smaller void ratio. The viscosity of the pore fluid at this temperature was also lower. These factors provided for better pore fluid drainage, and greater grain-to-grain contact. Thus, the material was stronger in compression. In summary, these results indicate that the compressive strength of the shale caprock was dependent on pressure, temperature, and loading path.

\subsection{TASK D.3: LONG-TERM CREEP/COMPACTION BEHAVIOR}

We conducted long-term creep compaction tests to study the impact of effective stress (the difference between the confining stress and the pore pressure) and temperature on the long-term deformational behavior of reservoir shale and heavy oil-sand. We used cores of the Faja Formation provided by INTEVEP and referred to as core numbers 49 (3202 to $3204 \mathrm{ft}$--shale), 51 (3206 to $3208 \mathrm{ft}$ - shale), and 70 (3278.83 to $3280.83 \mathrm{ft}$--heavy oil-sand), with an additional shale sample from a 3309.5-ft depth. In the first two tests, Creep 1 and Creep 2, we kept the samples at room temperature and measured the volume change with time at confining pressures of approximately $600,800,1200$, and 1600 psi $(4.14,5.52,8.28$, and $11.03 \mathrm{MPa})$. In all cases, we maintained the pore pressure at one-half the value of the confining pressure; thus, the effective stress was equal to the pore pressure. For the later tests, Creep 3, Creep 4, and Creep 5, we elevated the temperature to $125^{\circ} \mathrm{C}$ and kept the confining pressure equal to 800 psi ( $5.52 \mathrm{MPa}$ ), except for Creep 3 , in which we raised the confining pressure to $1200 \mathrm{psi}(8.28 \mathrm{MPa}$ ) later in the test.

We prepared the samples for the long-term creep tests in the same manner as we did for the uniaxial stress and PV tests. The preparation procedure is given in the previous section. In Creep 1, we used only one shale sample in the pressure vessel; for all the rest of the creep tests, three samples were in the vessel at one time. Temperature was controlled by a Microstar Heater Controller located outside of the pressure vessel. Two thermocouples placed inside the pressure vessel monitored the temperature, and the data were stored at one-hour intervals on the system computer. We used the heater only for the tests when temperature was to be held at $125^{\circ} \mathrm{C}$; for the $25^{\circ} \mathrm{C}$ tests, the vessel temperature was at ambient. In Creeps 1-4, the sample pore pressure was 
accessed through a porous spacer at only one end of the sample. In Creep 5, we put spacers on each end of the sample so that fluid could enter or exit the sample through both ends (doubly drained test). We maintained pore pressure at a value approximately one-half the confining pressure by manually adjusting the volumometers (see Fig. 6). During the first few hours of a test, we adjusted the pore pressure every 10 minutes. After the confining pressure and pore pressure stabilized, we adjusted the pore pressure less frequently and, eventually, only once or twice daily. The confining pressure was controlled by the computer once the system reached the desired temperature and pressure equilibrium. Confining pressure was raised at selected times during tests 1 , 2, 3, 4; and for a few hours after each increase in confining pressure, pore pressure was adjusted every 10 minutes.

The volumometer measured an increase or decrease in the sample pore volume by measuring the volume of fluid added to or removed from the sample each time the pore pressure was adjusted. The computer recorded values of the pore pressure, confining pressure, and temperature every hour, or more frequently when changes were made in the confining pressure. On some occasions, when the operator arrived to make the manual adjustment in the pore pressure, he noted that the pore pressure had changed considerably. In some cases, the pore pressure change affected the experimental results. These cases are discussed in the following sections.

\subsubsection{Results of the Long-Term Creep Tests}

The tests performed on the Faja reservoir rocks are summarized in Table D-1 in the order in which they were finished. The pressure and temperature conditions for each test and each sample are also listed. In each case, we tried to keep pore pressure equal to one-half the confining pressure. A time delay occurs between the time a change in the pressure setting is made and the time the pressure actually changes in the vessel; when large changes are made in the pressure, the system can become unstable. For this reason, we kept the pressure changes to a minimum. In some cases, the effective pressure was not exactly equal to one-half the confining pressure. In this section, we discuss details of the results of each test and illustrate the results with a semilogarithmic plot of the fractional volume change vs. elapsed time in hours. Tabulated listings of data for long-term creep tests are in Appendix $D$. 
Creep 1 (Table D-la and Fig. 26) illustrates typical behavior of a Faja shale sample. Initially the confining pressure was approximately 900 psi (6.21 MPa). It was raised to approximately $1300 \mathrm{psi}(8.97 \mathrm{MPa}$ ) after $210 \mathrm{hr}$ and to approximately $1700 \mathrm{psi}(11.7 \mathrm{MPa}$ ) after $375 \mathrm{hr}$. After an initial period of rapid change in volume when the pore pressure and confining pressure were first applied, the deformation became a linear function of the log of time. The initial rapid change in volume is generally referred to as primary compaction; the later stable linear change is referred to as secondary compaction. When the confining pressure was increased and the pore pressure was readjusted, another rapid decrease in volume (primary compaction) was followed by a period of stable secondary compaction. In Creep 1 , this happened in both successive changes in confining and pore pressure. At 300 $h r$, there is a short step in the linear part of the curve, which is the result of a change in the pore pressure (and, hence, the effective pressure) that caused a temporarily rapid decrease in the volume. We performed a linear regression on the linear parts of the curves at each confining pressure range to determine the slope of the curve, or $d\left(V / v_{0}\right) / d(\log t)$. In the initial linear part of the curve, for a $P_{E}$ (effective pressure) of 420 psi (2.90 $\mathrm{MPa}$ ), the slope was $-1.72 \times 10^{-3} \mathrm{~s}^{-1}$ (with volume change as a fraction, not a percent). For $P_{E}$ of $625 \mathrm{psi}$ ( $4.31 \mathrm{MPa}$ for the second portion of the test), the slope is $-6.0 \times 10^{-3} \mathrm{~s}^{-1}$ for the first linear portion and $-3.7 \times 10^{-3} \mathrm{~s}^{-1}$ for the second linear portion. For the last part of the test, when $P_{E}$ was 825 psi ( $5.69 \mathrm{MPa}$ ), the slope (determined by only two points) was $-1.2 \times 10^{-3} \mathrm{~s}^{-1}$. The success of this initial test led us to use a similar procedure for the subsequent tests on the Faja reservoir rocks.

In Creep 2, we used three different rocks--two shale and one oil-sand. The results are listed in Tables $D-2(a-d)$ and illustrated in Figs. $27(a-c)$. Three confining pressures were used, approximately 540, 1200, and 1600 psi $(3.72,8.28$, and $11.03 \mathrm{MPa})$. Pore pressures were different for each sample because we used separate volumometers. This test was run with temperature at ambient, approximately $25^{\circ} \mathrm{C}$. The $3206-\mathrm{ft}$ shale sample and $3280-\mathrm{ft}$ oil sand, sample showed similar behavior. For these two samples, we observed a small net increase in volume during the first $120 \mathrm{hr}$ of the test, when confining pressure $\left(P_{C}\right)$ was $540 \mathrm{psi}(3.72 \mathrm{MPa})$. When we increased $P_{c}$ and the pore pressure $\left(P_{p}\right)$ after $120 \mathrm{hr}$, the volume change behaved as we observed in the first creep test. The 3280-ft oil-sand sample volume increased a small 


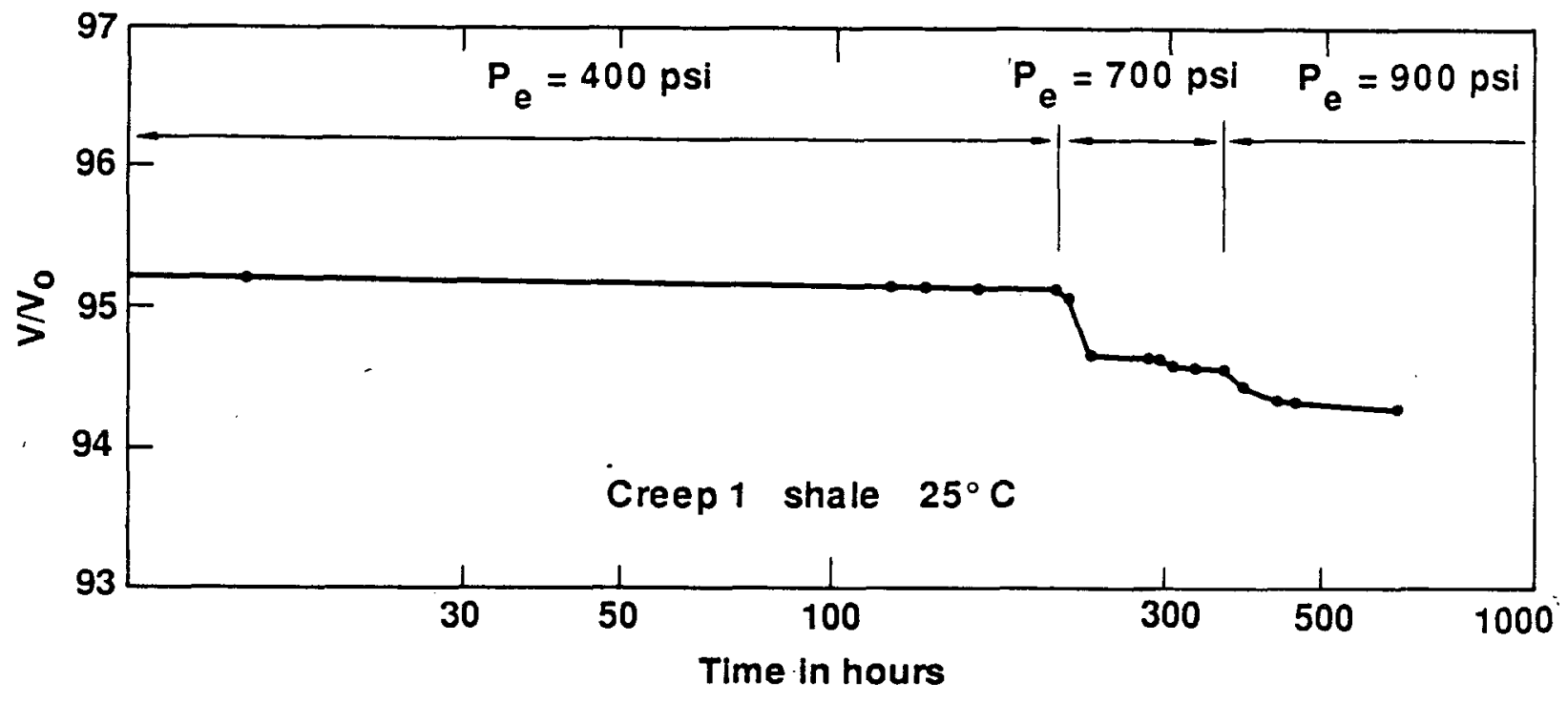

Figure 26. Creep results for a Faj shale sample, unknown depth. $V / V_{0}$ is expressed as a percent. 

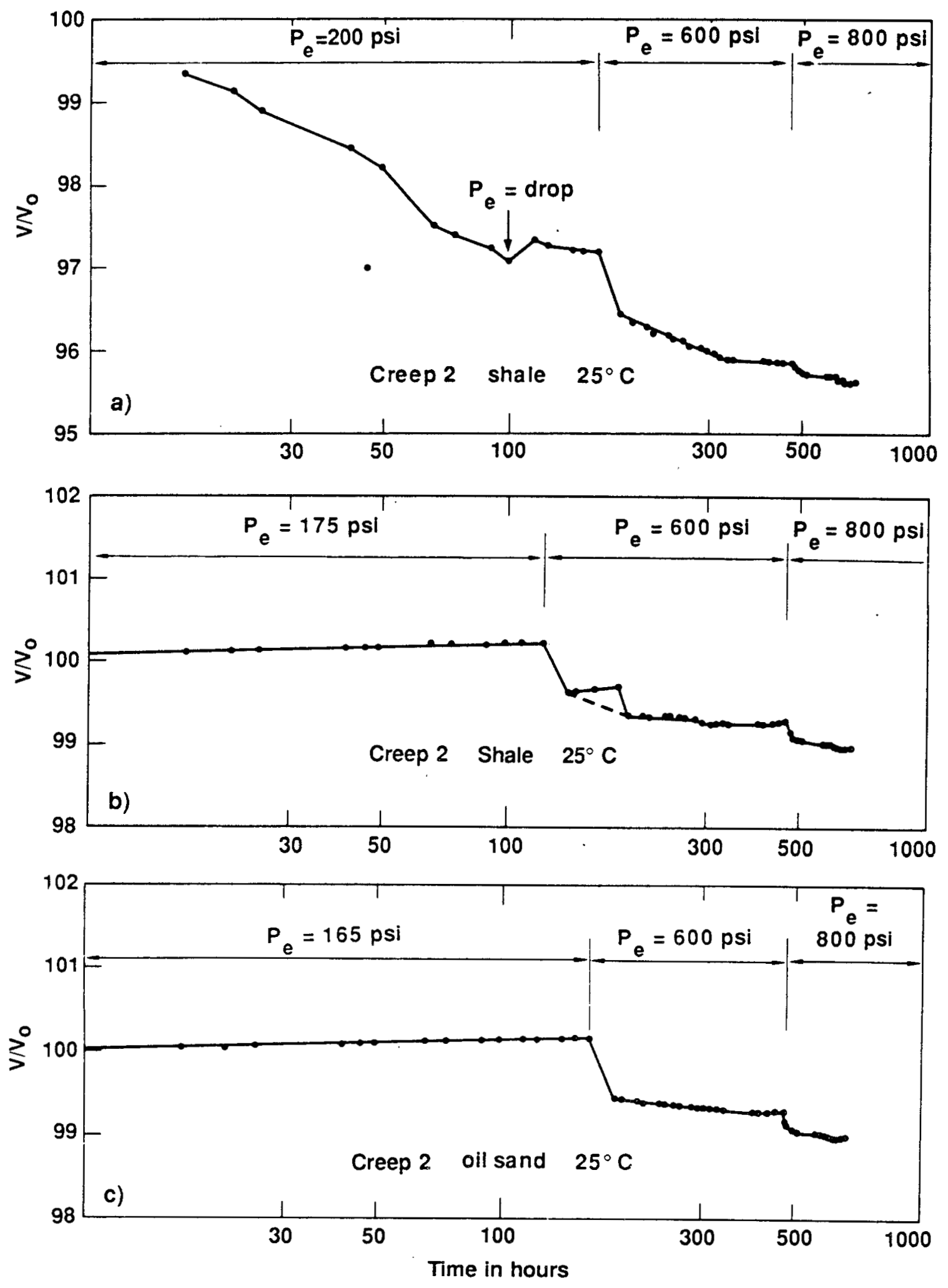

Figure 27. (a) Creep results for shale, $3309-\mathrm{ft}$ sample at $25^{\circ} \mathrm{C} . \mathrm{V} / \mathrm{V}_{\mathrm{o}}$ is expressed as a percent. (b) Creep results for shale, 3206-ft sample at $25^{\circ} \mathrm{C}$. $V / V_{0}$ is expressed as a percent. (c) Creep results for the oil-sand, 3280-ft sample at $250 \mathrm{C}$. 
amount approximately $140 \mathrm{hr}$ into the test, after $P_{c}$ was increased. This abberation in the volume change behavior was probably not due to a change in pressure conditions because the effective pressure $\left(P_{E}\right)$ was kept relatively constant (approximately $635 \pm 30 \mathrm{psi}$ ). After approximately $180 \mathrm{hr}$, the volume change behavior became log-linear with time. Slopes of $d\left(V / V_{0}\right) / d(\log t)$ for the samples are summarized in Table 5.

In Creep 3, (two shale samples and one oil-sand sample), we used confining pressures of 800 and $1200 \mathrm{psi}$ ( 5.5 and $8.27 \mathrm{MPa}$ ). Results of the test are listed in Tables $D-3(a-c)$. The temperature of the heater controller was maintained at approximately $125^{\circ} \mathrm{C}$ for this test; temperatures measured by thermocouples in the pressure vessel were approximately $4-5^{\circ} \mathrm{C}$ higher. From the beginning to the end of this test, the two shale samples showed an increase of pore volume with time. This led us to suspect a failure of the sample jacket. Upon completion of the test, we observed a rupture in the jacket of the 3202-ft shale sample. We did not observe any jacket leaks in the 3204-ft shale sample, but the data indicates that the jacket probably failed early in the test. The only good data for this test, then, is for the oil-sand sample; it is plotted in Fig. 28. The creep data shows erratic changes in volume up until approximately $290 \mathrm{hr}$ into the test, when a log-linear volume change with time becomes evident. The deviations from linear behavior [Fig. 28] were related to changes of $145 \mathrm{psi}$ ( $1.0 \mathrm{MPa}$ ) or more in $P_{E}$ during periods between times when the pore volume was readjusted. We used only points that fell on the linear trend of the curve when we determined the slopes of the volume-time behavior for this sample. The slope for the first segment of the curve, $P_{E}=450$ psi (2.99 MPa), was $-66.1 \times 10^{-3}$ $s^{-1}$. The slope for the second part of the curve, when the average Pe was $645 \mathrm{psi}(4.28 \mathrm{MPa})$ is $-103.8 \times 10^{-3} \mathrm{~s}^{-1}$.

Two shale samples and one oil-sand sample were again used in Creep 4 . In this case, we used only one value of confining pressure, which averaged 755 psi ( $5.21 \mathrm{MPa})$. Temperature was maintained at $125^{\circ} \mathrm{C}$, as it was in Creep 3 . The jacket of the 3207-ft shale sample failed early in the test as noted in Table D-4C. The oil-sand sample (Table D-4a, Fig. 29) hardly changed in volume between 10 and $100 \mathrm{hr}$, and then the volume decreased rapidly after approximately $145 \mathrm{hr}$, even though the pressure and temperature conditions were relatively constant, with an average $P_{E}$ of $520 \mathrm{psi}$ ( $3.59 \mathrm{MPa}$ ). The slope of the curve, when the volume decreased rapidly, was approximately $-146.0 \times 10^{-3} \mathrm{~s}^{-1}$. 


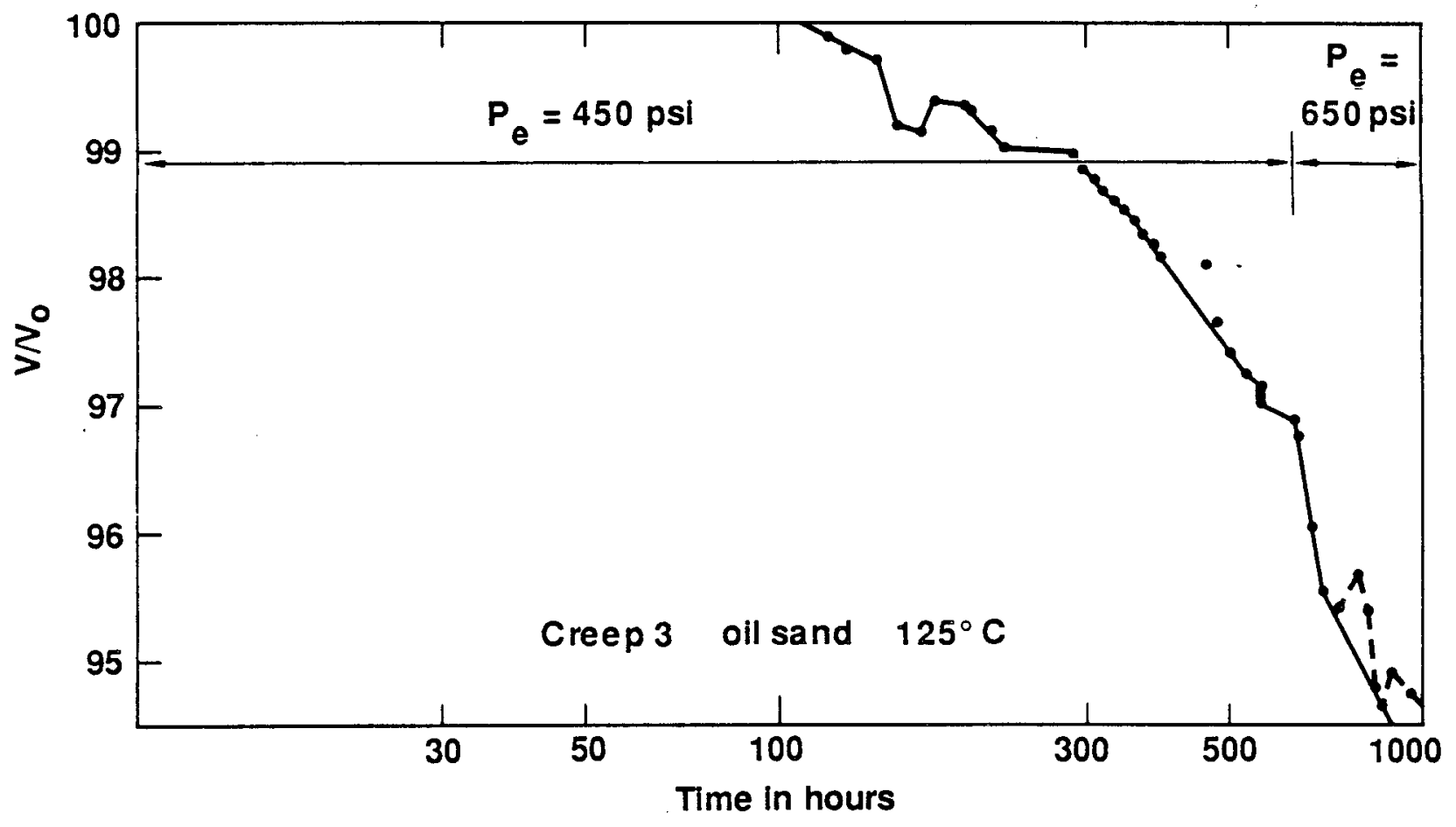

Figure 28. Creep results for the oil sand, $3280-\mathrm{ft}$ sample at $125^{\circ} \mathrm{C}$. 


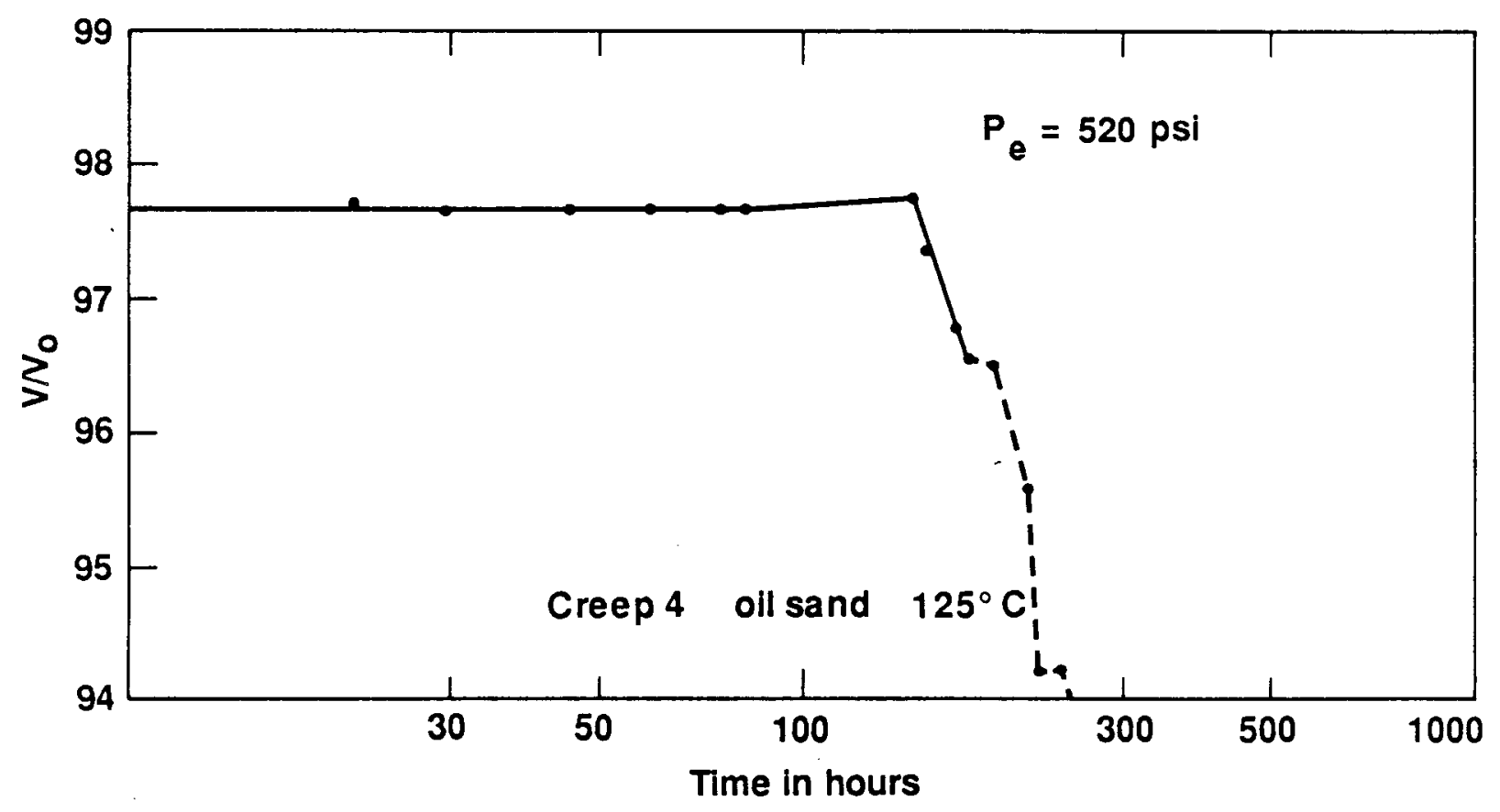

Figure 29. Creep results for the oil-sand, $3280-\mathrm{ft}$ sample at $125^{\circ} \mathrm{C}$. 
The 3202-ft shale sample also showed two log-linear segments of creep behavior, as seen in Fig. 30. The initial slope was $-6.52 \times 10^{-3} \mathrm{~s}^{-1}$; after $145 \mathrm{hr}$ the slope increased to $-44.5 \times 10^{-3} \mathrm{~s}^{-1}$. This change in slope occurred while $P_{E}$ was maintained at an average value of 463 psi ( 3.19 $\mathrm{MPa}$ ). The change in slope occurred at about the same time for both the shale and oil-sand samples, suggesting that some systematic change in the experimental conditions probably occurred at approximately $145 \mathrm{hr}$ into the test. However, we found nothing in the test records to indicate any large or unusual changes in the temperature or pressure conditions.

After obtaining the questionable results of Creep 4, we decided to repeat the test conditions for Creep 5. In Creep 5 we kept $P_{C}$ at approximately 800 psi ( $5.31 \mathrm{MPa}$ ) for the entire test run, which lasted almost $1000 \mathrm{hr}$. The temperature was maintained at $125^{\circ} \mathrm{C}$ as in Creep 3 and 4 . In Creep 5, the samples were allowed to drain from both ends of the sample, resulting in much better data. The data for Creep 5 (Tables $D-5(a-c)$ and Figs. 31 (a-c) are the best of the series. The two shale samples (3202- and 3206-ft) had a remarkably linear change in volume vs. the log of time throughout the entire test. The $d\left(V / V_{0}\right) / d(\log t)$ slope for $3202-f t$ shale was $-42.49 \times 10^{-3} \mathrm{~s}^{-1}$ for an average $P_{F}$ of $445 \mathrm{psi}(3.071 \mathrm{MPa})$. The slope for $3206-\mathrm{ft}$ shale was $-36.31 \times 10^{-3} \mathrm{~s}^{-1}$ for time less than $300 \mathrm{hr}$, and $-40.26 \times 10^{-3} \mathrm{~s}^{-1}$ for time greater than $300 \mathrm{hr}$, for an average $P_{E}$ of $428 \mathrm{psi}$ (2.96 MPa). The oil-sand sample [Fig. 31(c)] showed an increase in the rate of volume change after $600 \mathrm{hr}$, from a slope of $-77.2 \times 10^{-3} \mathrm{~s}^{-1}$ (less than $200 \mathrm{hr}$ ) and -68.2 $\times 10^{-3} \mathrm{~s}^{-1}$ (200 to $600 \mathrm{hr}$.) to $-112.7 \times 10^{-3} \mathrm{~s}^{-1}$ after 600 hours. The average $P_{E}$ for the oil-sand sample was $380 \mathrm{psi}(2.52 \mathrm{MPa}$ ) in this test.

\subsubsection{Long-Term Creep: Summary and Conclusions}

Our creep tests were inherently different than the standard type of creep test discussed by other workers. Most drained creep tests of which we are aware are standard compaction or loading tests in which a uniform, time-invariant uniaxial load is applied to a sample under confining pressure and the length change of the sample is monitored over time. In our tests, the internal pore volume change was monitored over time for conditions in which 


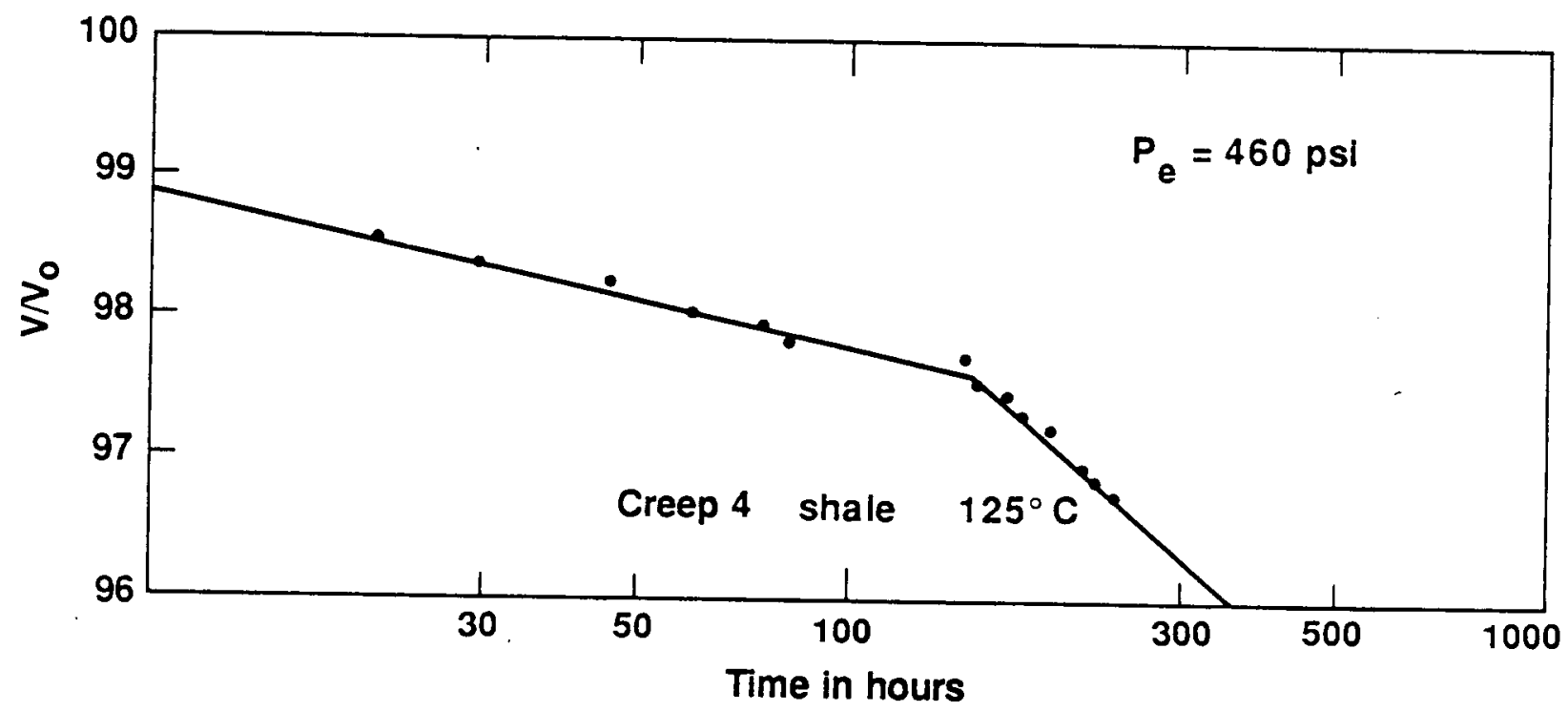

Figure 30. Creep results for shale, 3202-ft sample at $125^{\circ} \mathrm{C}$. 

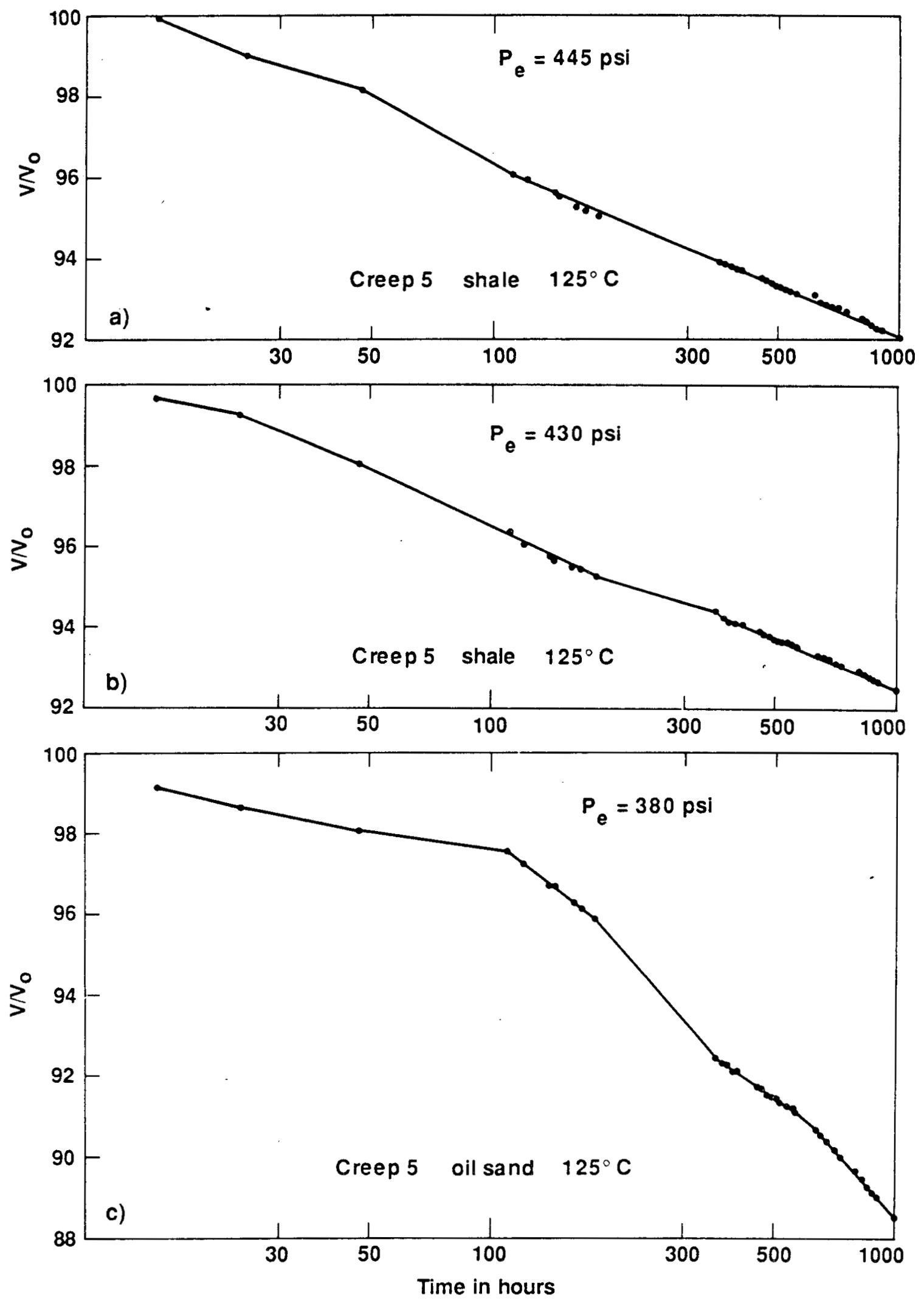

Figure 31. (a) Creep results for the shale, 3202-ft sample at $125^{\circ} \mathrm{C}$; (b) creep results for the shale, $3206-\mathrm{ft}$ sample at $125^{\circ} \mathrm{C}$; and (c) creep results for the oil-sand, $3278-\mathrm{ft}$ sample at $125^{\circ} \mathrm{C}$. 
the temperature, pore pressure, and confining pressure were held as constant as possible under the experimental procedures. Because of the experimental procedures and very few volumometer adjustments, we were unable to completely assure that the pore pressure was constant at all times. Nevertheless, the experimental results indicate that in most cases the relatively small changes in $P_{E}$ that occurred between times when the pore volume was adjusted did not significantly affect the overall results. Creep 5 shows that the data was improved by draining the sample from both ends. We recommend that porous spacers and pore pressure connections be made at both ends of the sample in future creep tests.

Even though these experiments were somewhat different than the standard type of creep test, we did observe a linear change in volume as a function of the log of time, as has been observed in standard types of creep tests on solid rock. In Table 6 , we list the slopes of the curves of volume change vs. log time for the shale and oil-sand rock types, the two temperatures, and the various effective pressures used. The only systematic effects that we can note from Table 6 are that the rate of volume change with time was larger at 125 than $25^{\circ} \mathrm{C}$ for both the shale and oil-sand samples. Results also indicate that the rate of volume change with time is a very sensitive function of the effective pressure, although our data are not sufficiently complete to determine any systematic behavior.

Creep tests are inherently difficult to complete successfully because many opportunities arise for things to go wrong during a test that lasts 1000 hr or more. The tests that we report here should be considered only preliminary determinations of certain aspects of the creep behavior of the reservoir rocks studied. We suggest that these data be used only to gain insight into long-term deformational behavior of reservoir rocks and that the data probably are not suitable for making detailed calculations of reservoir behavior.

\section{SUMMARY AND CONCLUSIONS}

The PV tests indicate that the bulk modulus of the "undisturbed" heavy oil-sand samples was 430-670 MPa. Increasing the temperature on unconfined oil-sand to $125^{\circ} \mathrm{C}$ causes thermal cracking or some other mechanism that expands the sample, creating about $5 \%$ void. However, the void closed at effective 
Table 6. Summary of long term creep test results.

Temperature $25^{\circ} \mathrm{C}$

Sample

Shale 3309

Shale

Shale 3309

Shale 3206

Shale

Shale

Shale 3309

Shale 3206

0il-sand 3280

0il-sand 3280
$\underline{P}_{E}-$ psi) $\quad \underline{\text { Slope }}\left(\underline{s}^{-1} \times 10^{-3}\right)$

200

420

600

615

625

825

800

820

635

836
$-20.0$

$-1.72$

$-19.9$

$-4.24$

$-3.7$

$-1.2$

$-11.7$

$-8.65$

$-3.63$

$-8.06$
Temperature $125^{\circ} \mathrm{C}$

Sample

$\underline{P}_{E}(p s i)$

Slope $\left(\mathrm{s}^{-1} \times 10^{-3}\right)$

Shale 3202

Shale 3202

Shale 3206

463

445

430

$-44.5$

$-42.5$

$-36.3,-40.3$
Oil-sand 3278

0il-sand 3280

oil-sand 3280
380

450

520
$-77.2,-68.2,-112.7$

$-66.1$

$-146.0$ 
pressures above $7.5 \mathrm{MPa}$, and the rock behaved as it would at room temperature. This implies that, at in situ reservoir pressures, heating the oil-sand to $125^{\circ} \mathrm{C}$ will have very little effect on the bulk modulus. Another result is that, at both 25 and $125^{\circ} \mathrm{C}$, the decrease in volume with increasing effective pressure results from permanent pore compaction that occurs as pore fluid is expelled from the sample.

Tests on disturbed oil-sand samples indicate that the void introduced by mechanical disturbance was closed as effective pressure was raised above $7.5 \mathrm{MPa}$ and that a disturbance of $10 \%$ axial strain may cause some permanent compaction of oil-sand. Increasing temperature from 23 to $125^{\circ} \mathrm{C}$ had very little effect on the disturbed oil-sand samples.

Results of PV tests for shale indicate that at $23^{\circ} \mathrm{C}$ the shale compresses linearly with a bulk modulus of $\sim 2100 \mathrm{MPa}$. However, heating to $125^{\circ} \mathrm{C}$ caused mechanical disturbance and opened pore space and/or cracks in the friable shale sample. These cracks closed as effective pressure was raised above $45 \mathrm{MPa}$. More importantly, at effective pressures to $45 \mathrm{MPa}$, the bulk modulus of the $125^{\circ} \mathrm{C}$ sample was significantly less than that of the $23^{\circ} \mathrm{C}$ sample, showing that the high temperature shale was more compressible. This might be due to changes in the viscosity and compressibility of the oil phase present in the shale or to other mechanisms such as changes in surface tension of liquid phases with temperature. The tests also show that at $23^{\circ} \mathrm{C}$ mechanical disturbance significantly affected the PV behavior of shale; at pressures equivalent to those in the reservoir, the bulk modulus was reduced by as much as a factor of 2. Mechanical disturbance had less effect at $125^{\circ} \mathrm{C}$. Moreover, these results indicate that, at pressures equivalent to reservoir conditions, all disturbed shale samples had bulk modulus in the range of 800 to $1200 \mathrm{MPa}$.

Triaxial tests on oil-sand indicate that temperature had very little effect on the unconfined compressive strength. Compressive strength of oil-sand increased with increasing effective stress, and samples tested at 23 and $125^{\circ} \mathrm{C}$ and at equivalent pressures had similar strengths. Ultimate stress for these samples ranged from $0.25 \mathrm{MPa}$ for unconfined samples to more than 30 MPa for samples tested at an effective pressure of $150 \mathrm{MPa}$. Most of the oil-sand samples showed strain-hardening behavior, and some of the samples tested at $23^{\circ} \mathrm{C}$ showed evidence of failure by faulting events. Failure by faulting was not observed in samples tested at higher temperatures. Raising the temperature from 23 to $125^{\circ} \mathrm{C}$ did not have a major effect on the compressive 
strength of oil-sand. Mohr-Coulomb failure analysis obtains an angle of internal friction of approximately 8 degrees at effective pressures below 25 $\mathrm{MPa}$ and essentially no internal friction at higher effective pressures.

Tests on shale indicate that, as expected, compressive strength increased with increasing effective pressure and that ultimate strength for this formation ranges from approximately $1 \mathrm{MPa}$ for unconfined samples to more than $70 \mathrm{MPa}$ for a sample tested at $250^{\circ} \mathrm{C}$ and effective pressure of $150 \mathrm{MPa}$. The results for the shale samples are quite variable. However, Mohr-Coulomb failure envelopes for the shales clearly show that, at pressures above $25 \mathrm{MPa}$, the shear strength of shale increases with increasing temperature. These results may be dependent on load path.

Results of long-term creep compaction tests show that there is a linear change in sample volume as a function of the log of time and that the rate of volume change with time was larger at $125^{\circ} \mathrm{C}$ than at $25^{\circ} \mathrm{C}$ for both shale and oil-sand. Results also indicate that the rate of volume change with time is dependent on effective pressure.

\section{Acknowledgments}

The authors wish to thank Ernie Arnold and Marvin Christensen who were of great assistance in setting up the experimental apparatus. The late Hugh Heard provided initial designs of the apparatus and experimental program. Sue Stull and Sandy Wander edited the manuscript and Tonya Fletcher provided excellent support in typing and production of the report. 


\section{REFERENCES}

1) Johnston, D. H., Shale properties at temperature and pressure. 0il \& Gas Journal, Nov. 3, 1986.

2) Jandel Corporation, 2656 Bridgeway, Sausalito, CA 1985.

3) Lotus Development Corporation, 161 First St., Cambridge, MA 1983.

4) Tull, J. E., SAC, A Signal Processing System for Research Seismology. Proceedings IEEE Int'l Symp. Circuits and Systems, San Jose, CA May 5-7, 1986. 
APPENDIX A

TABULATED DATA FOR PV TESTS ON UNDISTURBED AND DISTURBED SAMPLES OF OIL-SAND AND SHALE 
FILE INDEX VZPV.WKS - PRESSURE/VOLUME TESTS

$\begin{array}{lccccc}\text { TEST \# WKS-LOC } & \text { P-C } & \text { TEMP } & \text { SAMPLE } & \text { SAMPLE } & \text { DISTURBANCE } \\ \text { (MPa) } & \text { ( C) } & \text { TYPE } & \# & \end{array}$

2

5

3

4
WI

AY 1

AEI

AOI
50

OS $\quad$ PV32

OS PVIO

50

OS PV1/3a

OS PV25

OS PV24

$\begin{array}{lll}23 & \text { SH } & \text { PV9 } \\ & \text { SH } & \text { PV5 } \\ \text { SH } & \text { PV4 }\end{array}$

125 SH PV33

SH

$\mathrm{SH}$
PV7

PV23
$0 \%$

$10 \%$

$0 \%$

$10 \%$

$0 \%$

$5 \%$

$10 \%$

$0 \%$

$5 \%$

$10 \%$ 


$\begin{array}{rccc}\text { PV TEST \#2 } & \text { OIL-SAND } & T=23 \mathrm{C} \\ \text { DEL V / VO } & \\ \begin{array}{c}\text { P-eff } \\ \text { (MPa) }\end{array} & \text { OS-PVI0 } & \text { OS-PVII } & \text { OS-PV32 } \\ & 10 \% & 5 \% & 0 \% \\ 0 & 0.000 & 0.000 & 0.000 \\ 2.5 & 0.059 & 0.067 & 0.000 \\ 7.5 & 0.080 & 0.083 & 0.014 \\ 5 & 0.076 & 0.078 & 0.009 \\ 15 & 0.100 & 0.104 & 0.030 \\ 25 & 0.122 & 0.129 & 0.054 \\ 35 & 0.127 & 0.150 & 0.071 \\ 45 & 0.127 & 0.165 & 0.084 \\ 35 & 0.127 & 0.163 & 0.084 \\ 25 & 0.127 & 0.161 & 0.082 \\ 15 & 0.126 & 0.156 & 0.077 \\ 5 & 0.118 & 0.148 & 0.071 \\ 7.5 & 0.121 & 0.152 & 0.074\end{array}$




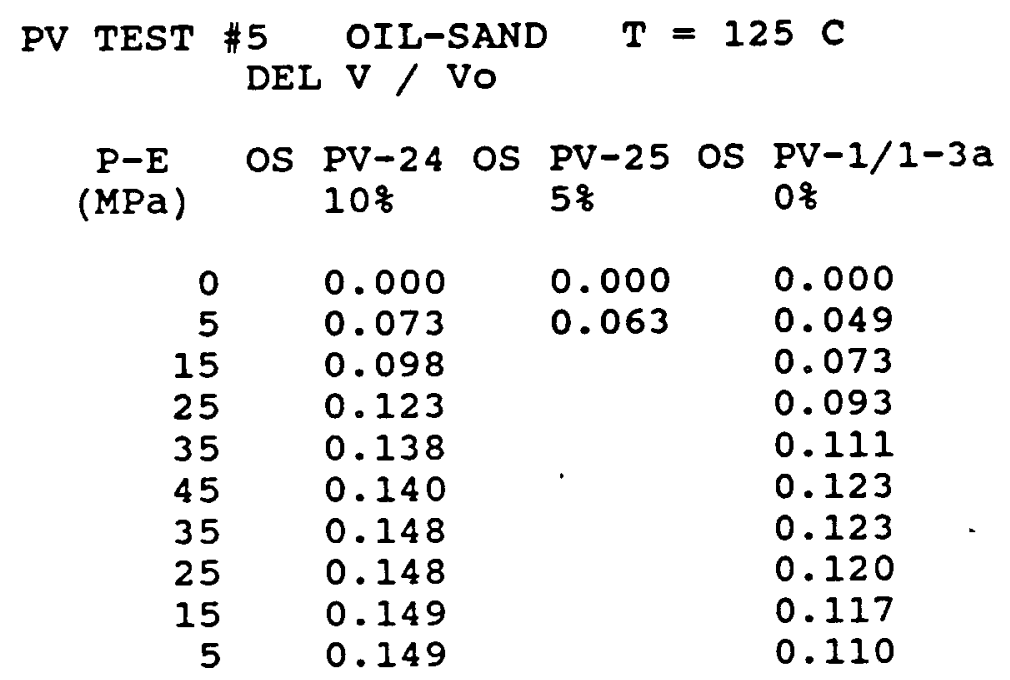




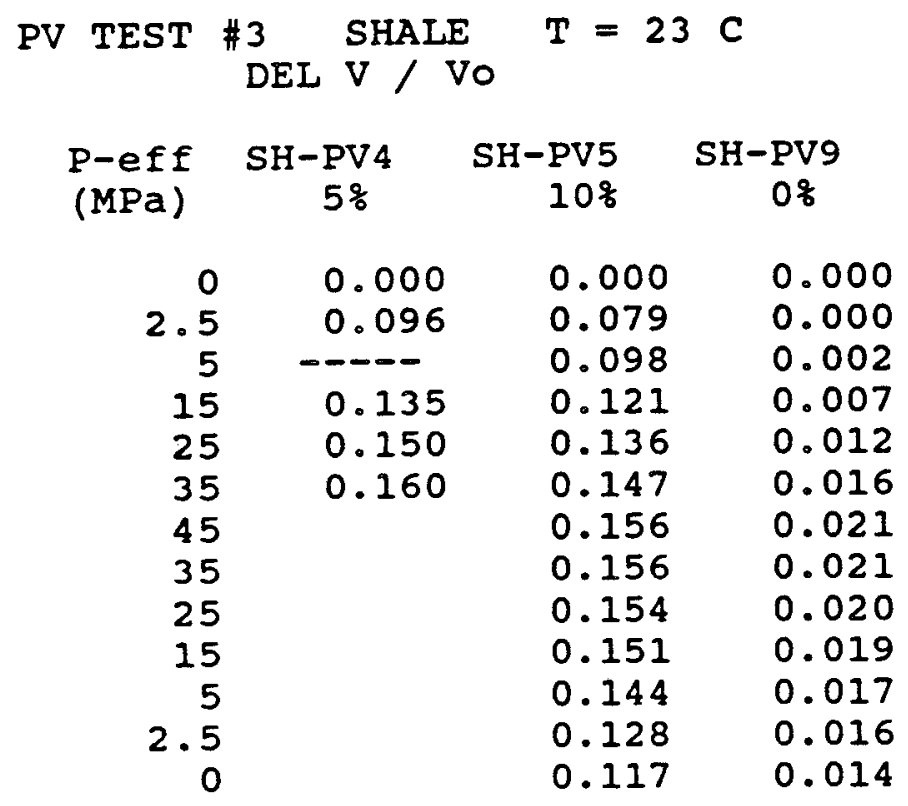


PV TEST \#4 $\begin{aligned} \text { SHALE } \\ \text { DEL } V / \text { VO }\end{aligned}$

P-eff SH-PV7 SH PV-33 SH-PV23

(MPa) $\quad 5 \%$ O\& $10 \%$

$\begin{array}{rlll}0 & 0.000 & 0.000 & 0.000 \\ 5 & 0.051 & 0.047 & 0.056 \\ 15 & 0.067 & 0.057 & 0.094 \\ 25 & 0.080 & 0.065 & 0.104 \\ 35 & 0.091 & 0.070 & 0.112 \\ 45 & 0.100 & 0.077 & 0.121 \\ 35 & 0.100 & 0.076 & 0.119 \\ 25 & 0.100 & 0.073 & 0.129 \\ 15 & 0.097 & 0.069 & 0.128 \\ 5 & 0.092 & 0.063 & 0.127\end{array}$


APPENDIX B

STRESS-STRAIN PLOTS AND TABULATED DATA FOR TRIAXIAL TESTS CONDUCTED ON OIL-SAND SAMPLES 
FILE INDEX VZOSAND.WKS - TRIAXIAL TESTS FOR OIL SAND

SAMPLE PC TYPE TEMP C LOCATION WKS

$\begin{array}{lrll}\text { PV11 } & 0.1 \text { OIL-SAND } & 23 \mathrm{L1} \\ \text { PV10 } & 0.1 \text { OIL-SAND } & 23 \mathrm{V1} \\ \text { PV18 } & 5 \text { OIL-SAND } & 23 \text { AE1 } \\ \text { PV17 } & 10 \text { OIL-SAND } & 23 \text { AN1 } \\ \text { PV16 } & 20 \text { OIL-SAND } & 23 \text { AW1 } \\ \text { PV15 } & 50 \text { OIL-SAND } & 23 \text { BF1 } \\ \text { PV25 } & 0.1 \text { OIL-SAND } & 125 \text { A200 } \\ \text { PV24 } & 0.1 \text { OIL-SAND } & 125 \mathrm{~J} 200 \\ \text { PV21 } & 10 \text { OIL-SAND } & 125 \mathrm{~S} 200 \\ \text { PV20 } & 20 \text { OIL-SAND } & 125 \text { AB200 } \\ \text { PV20A } & 20 \text { OIL-SAND } & 125 \text { AK200 } \\ \text { PV19 } & 50 \text { OIL-SAND } & 125 \text { AT200 } \\ \text { PV32 } & 300 \text { OIL-SAND } & 125 \mathrm{BC200} \\ \text { PV30 } & & & \\ \text { PV31 } & 0.1 \text { OIL-SAND } & 250 \text { A300 }\end{array}$


Figure B-1

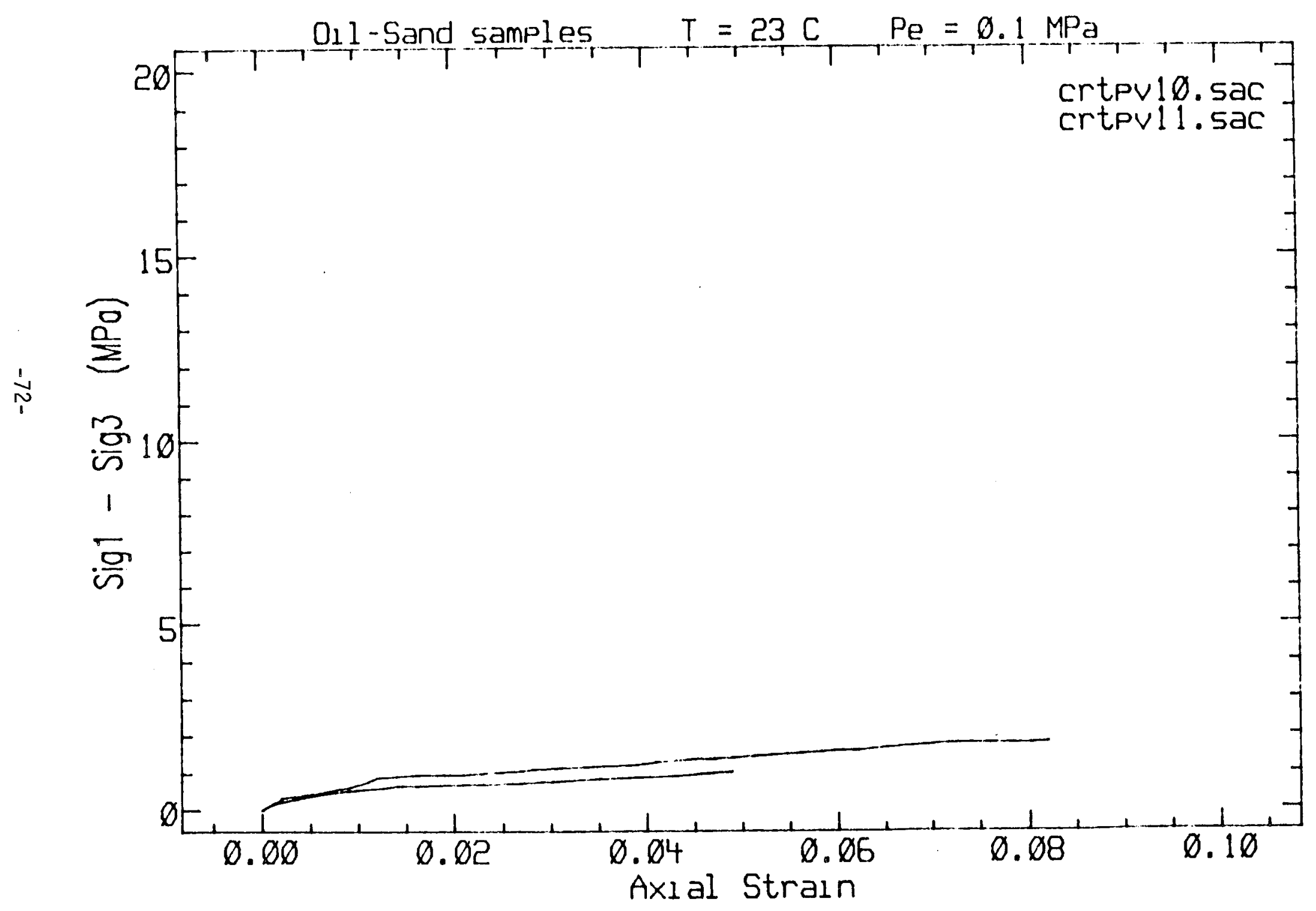




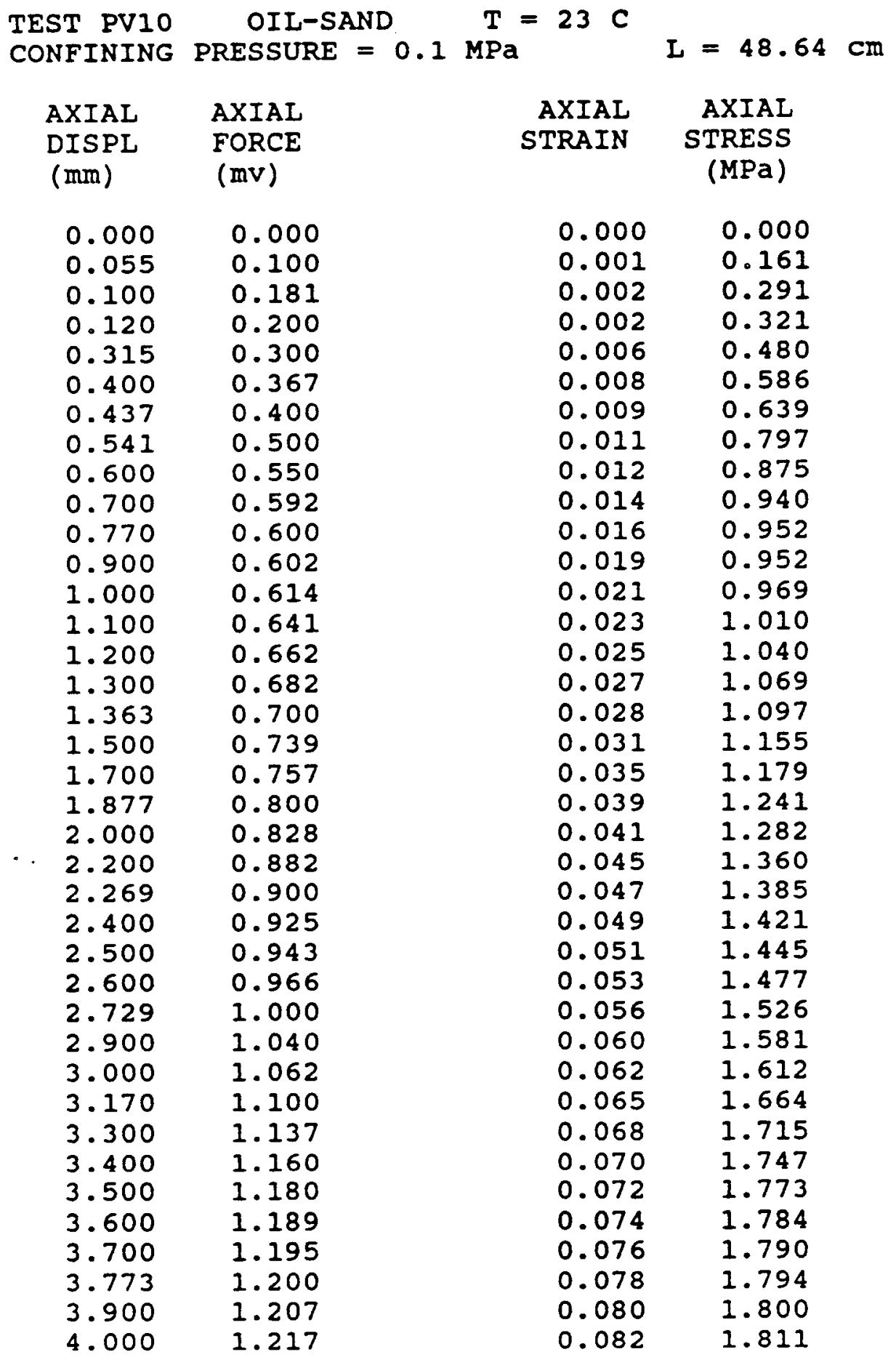




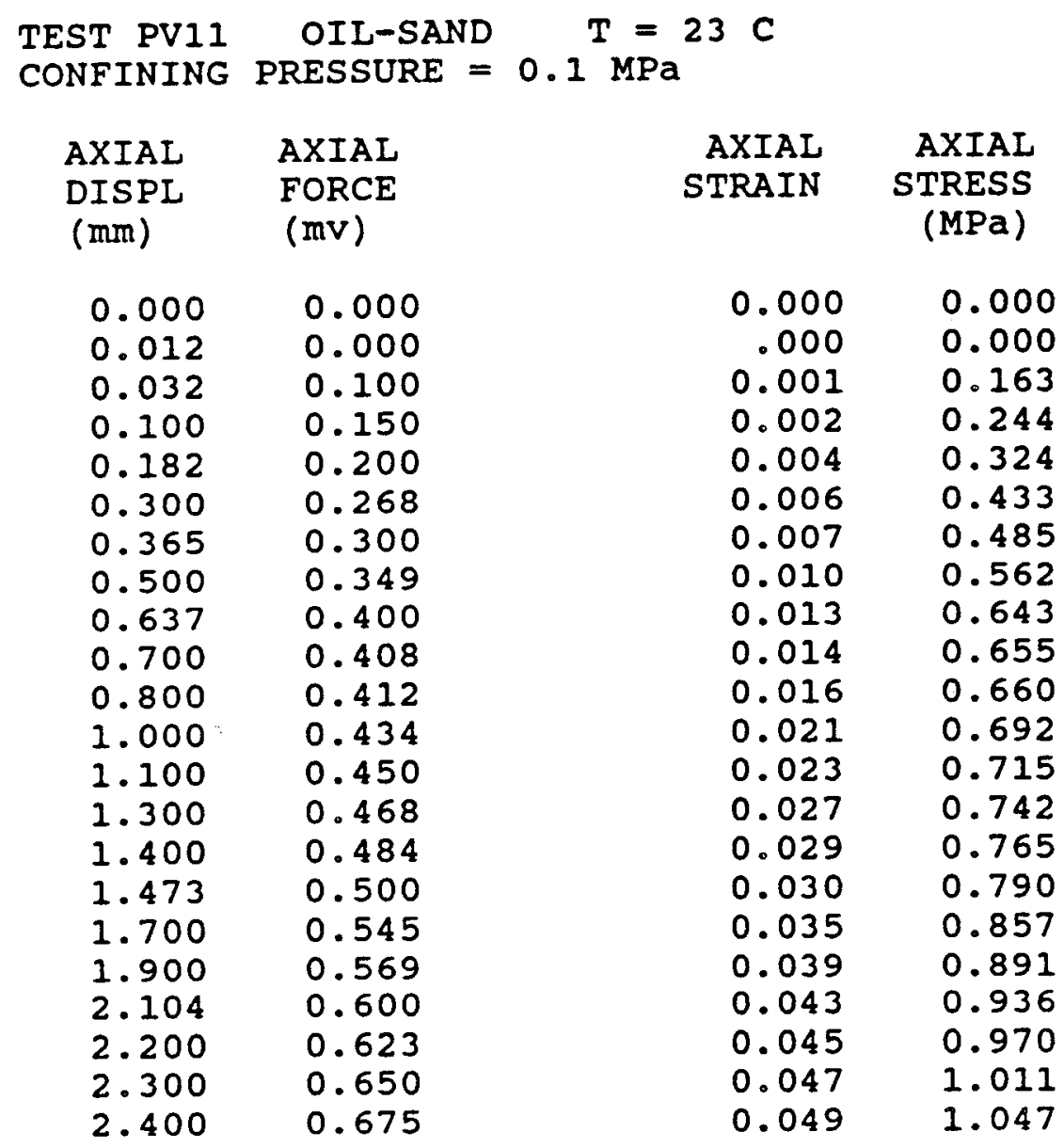


Figure B-2

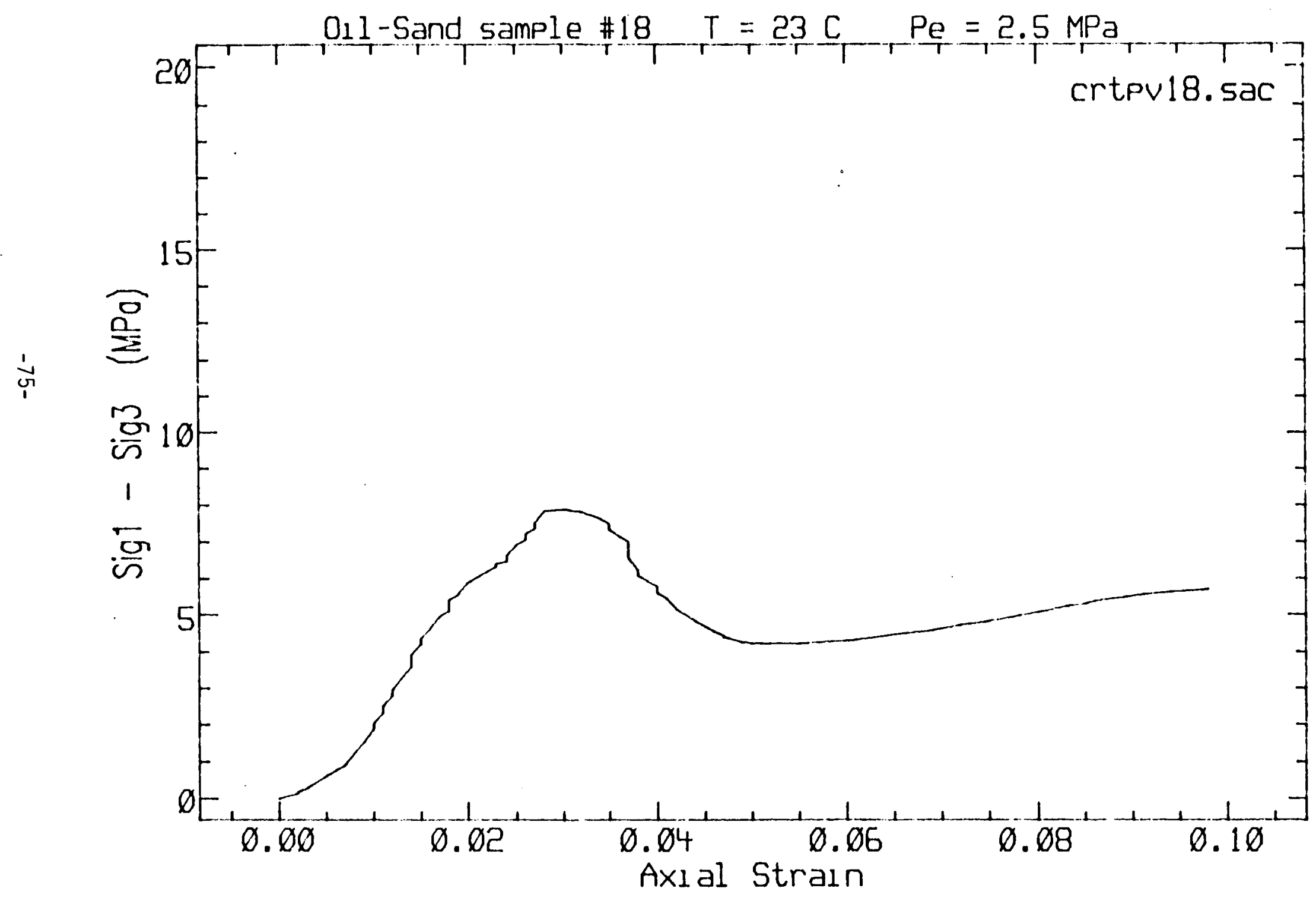


$\begin{array}{lcr}\text { TEST PVI8 } & \text { OIL-SAND } & \mathrm{T}=23 \mathrm{C} \\ \text { CONFINING } & \text { PRESSURE }=5 \mathrm{MPa}\end{array}$

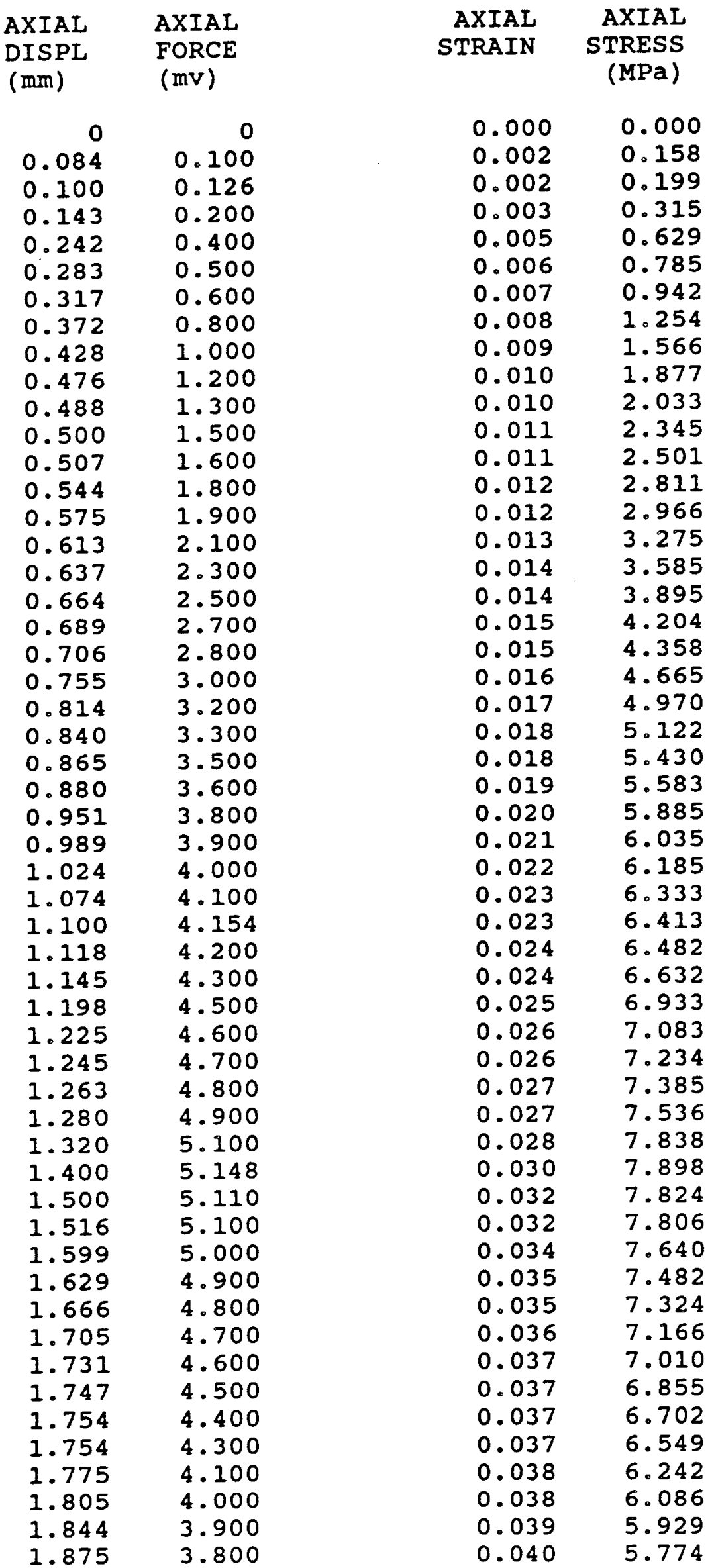




$\begin{array}{llll}1.900 & 3.700 & 0.040 & 5.619 \\ 1.926 & 3.600 & 0.041 & 5.464 \\ 1.994 & 3.400 & 0.042 & 5.153 \\ 2.068 & 3.200 & 0.044 & 4.843 \\ 2.123 & 3.100 & 0.045 & 4.686 \\ 2.175 & 3.000 & 0.046 & 4.530 \\ 2.200 & 2.944 & 0.047 & 4.443 \\ 2.220 & 2.900 & 0.047 & 4.375 \\ 2.300 & 2.812 & 0.049 & 4.236 \\ 2.354 & 2.800 & 0.050 & 4.213 \\ 2.570 & 2.800 & 0.055 & 4.195 \\ 2.600 & 2.808 & 0.055 & 4.204 \\ 2.700 & 2.839 & 0.057 & 4.242 \\ 2.855 & 2.900 & 0.061 & 4.320 \\ 3.070 & 3.000 & 0.065 & 4.449 \\ 3.249 & 3.100 & 0.069 & 4.581 \\ 3.387 & 3.200 & 0.072 & 4.716 \\ 3.523 & 3.300 & 0.075 & 4.851 \\ 3.663 & 3.400 & 0.078 & 4.984 \\ 3.798 & 3.500 & 0.081 & 5.117 \\ 3.930 & 3.600 & 0.083 & 5.249 \\ 4.000 & 3.655 & 0.085 & 5.322 \\ 4.058 & 3.700 & 0.086 & 5.382 \\ 4.197 & 3.800 & 0.089 & 5.512 \\ 4.300 & 3.851 & 0.091 & 5.574 \\ 4.443 & 3.900 & 0.094 & 5.630 \\ 4.600 & 3.964 & 0.098 & 5.705\end{array}$


Figure B-3

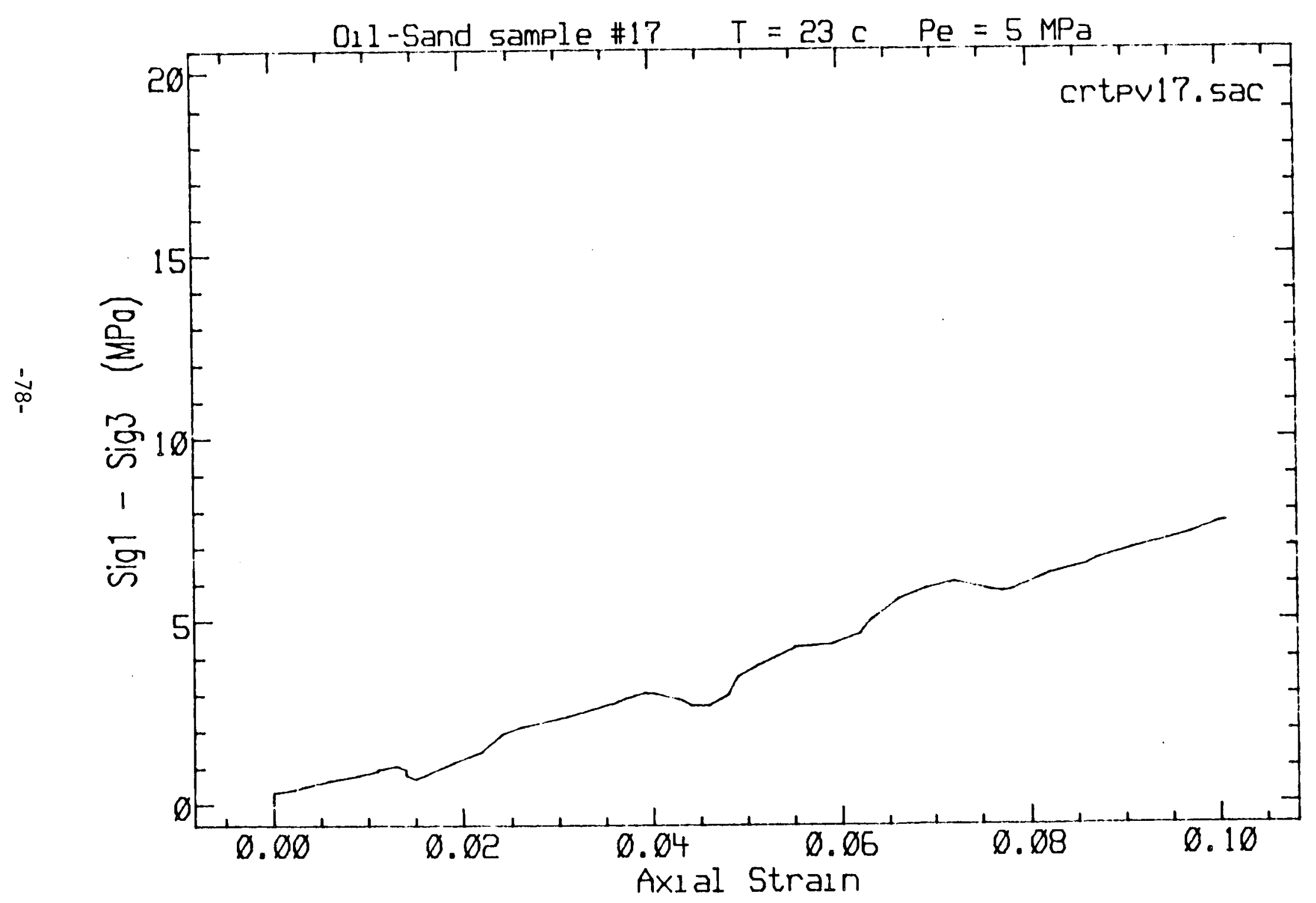


TEST PVI7 OIL-SAND $T=23 \mathrm{C}$

CONFINING PRESSURE $=10 \mathrm{MPa}$

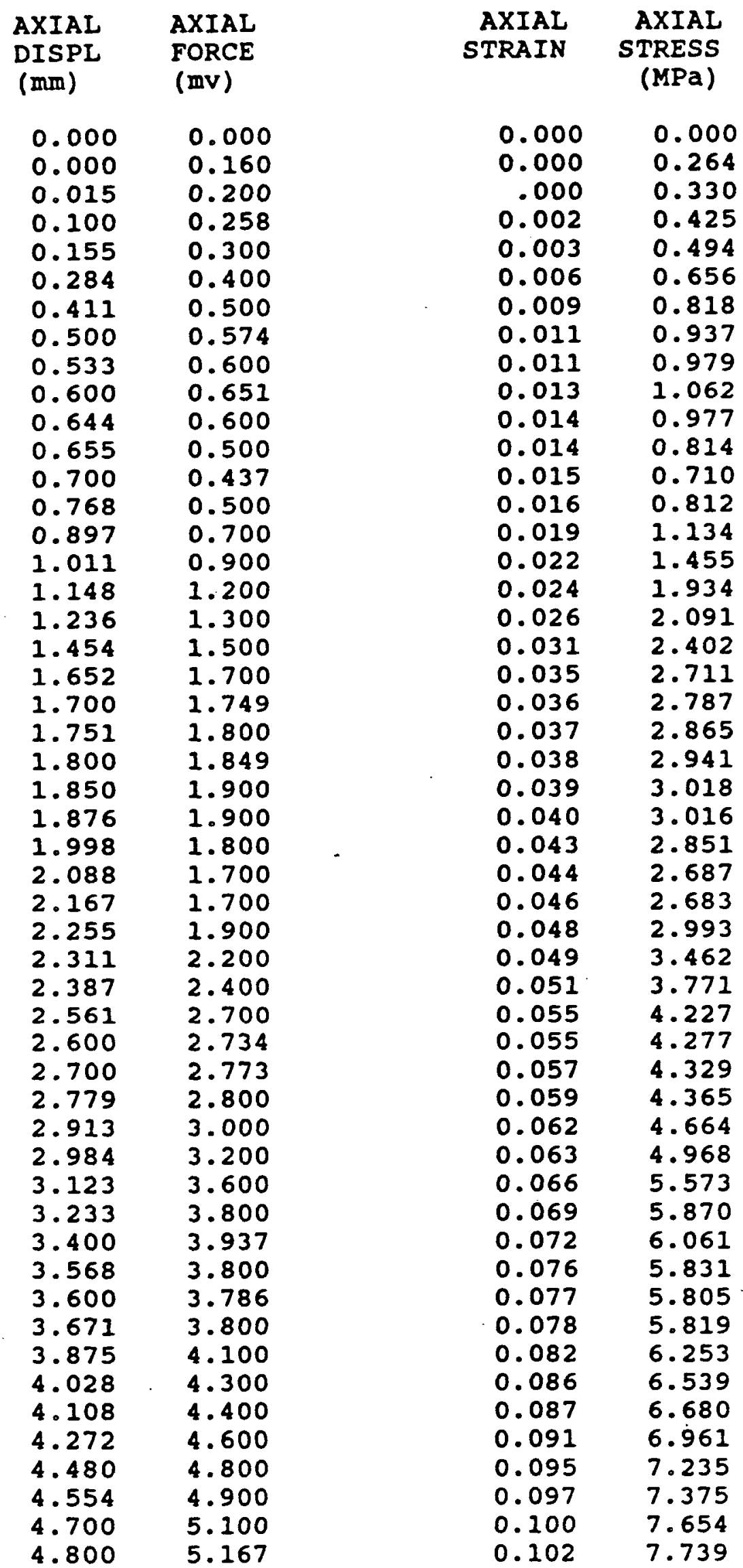


Figure B-4

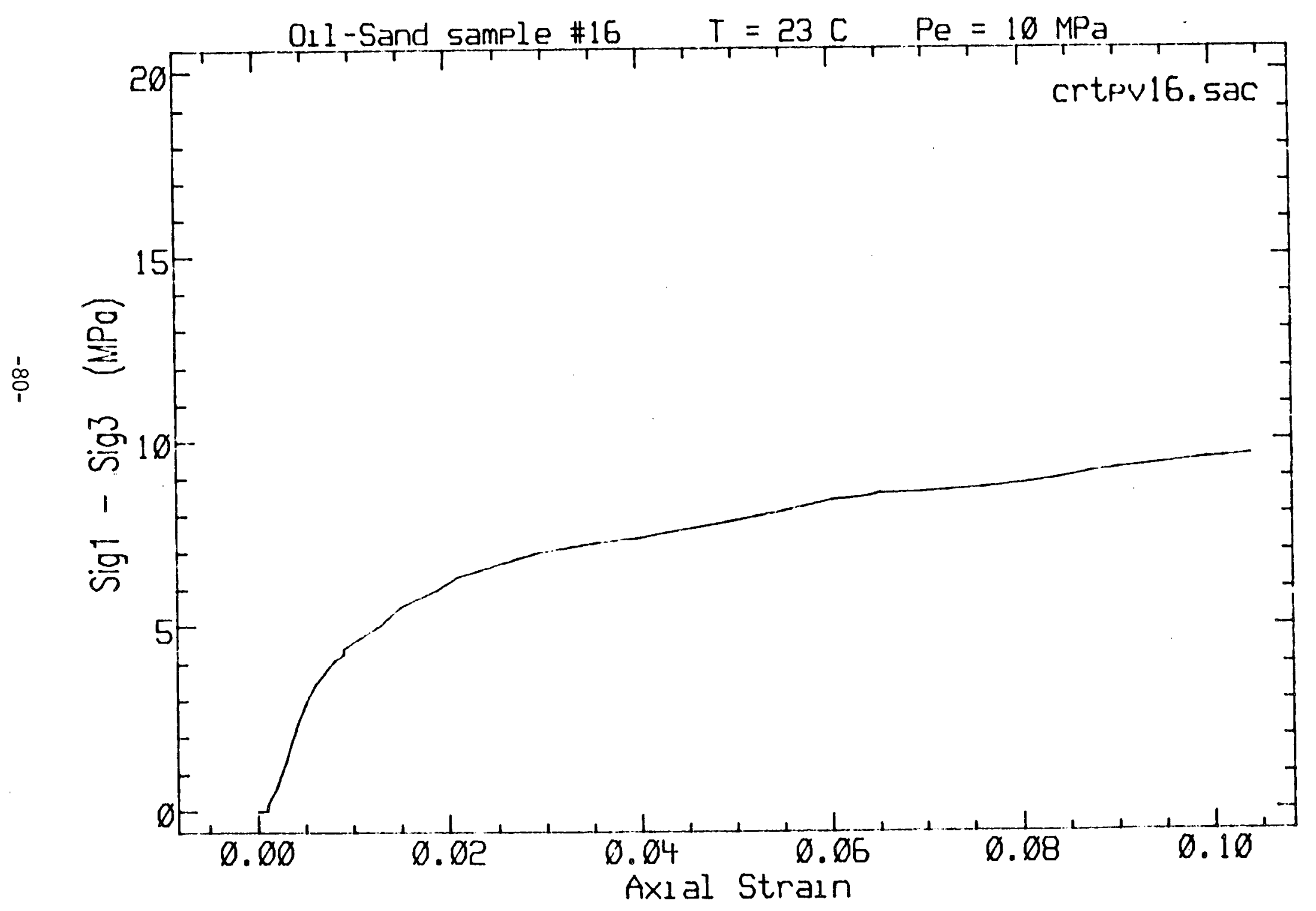




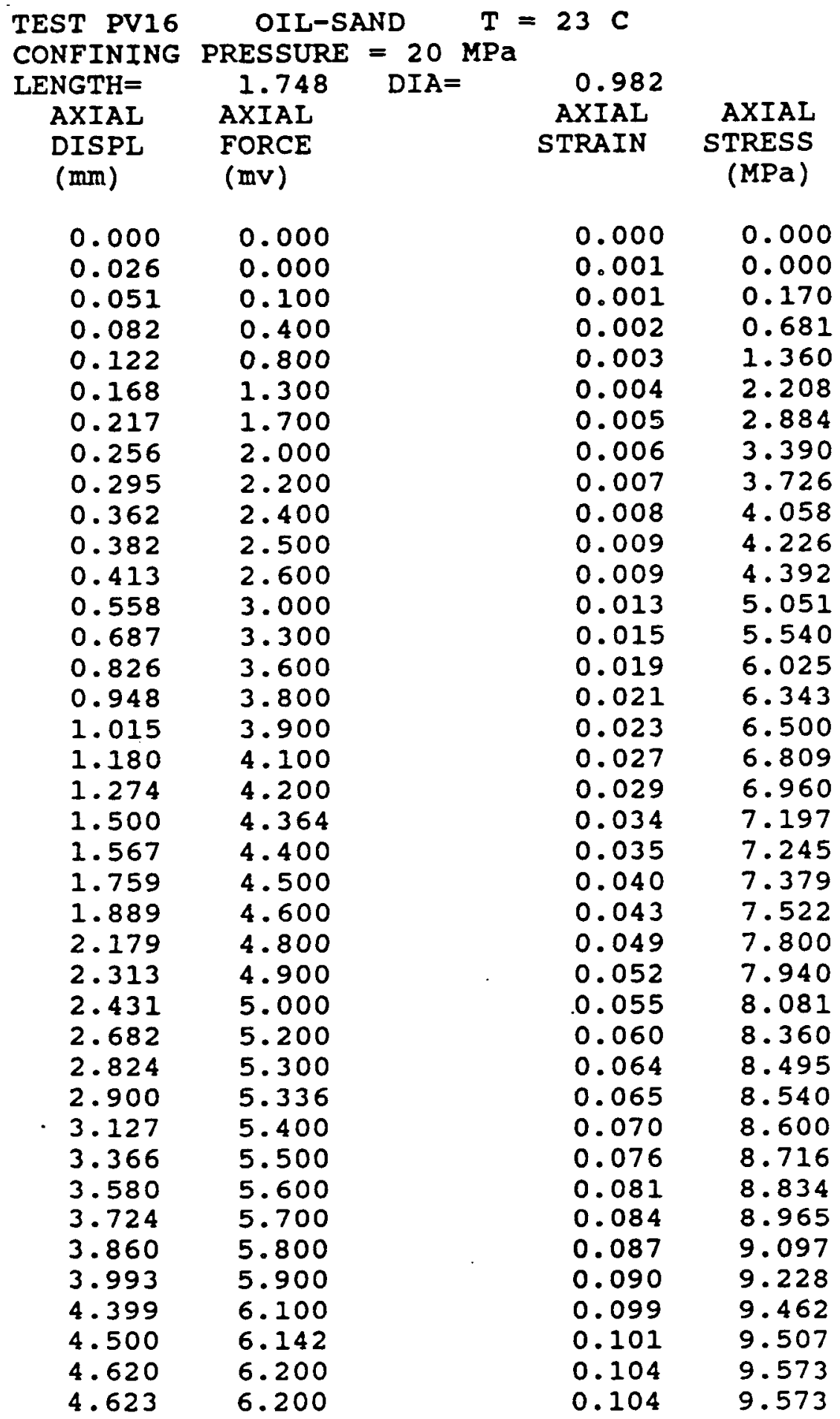


Figure B-5

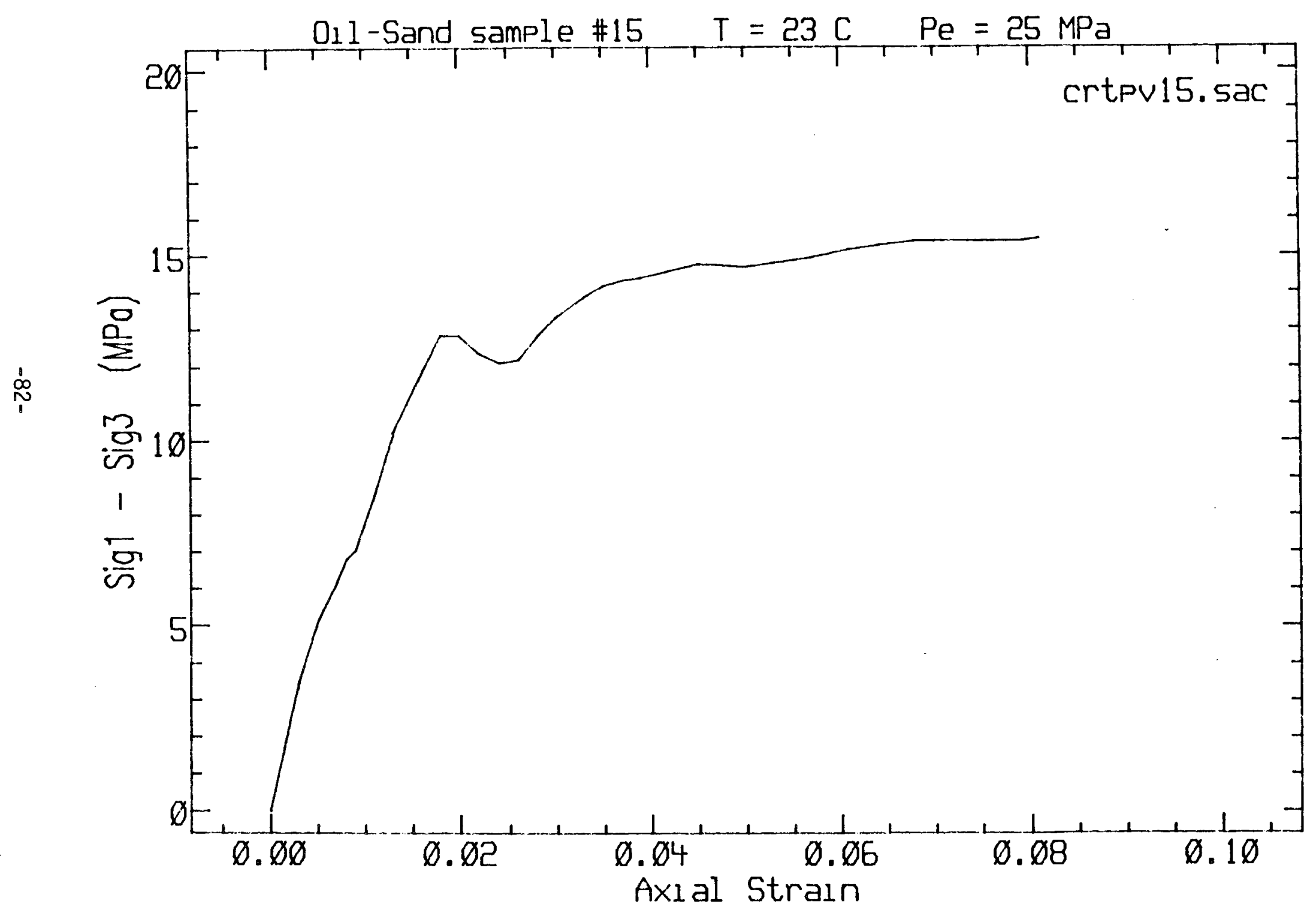




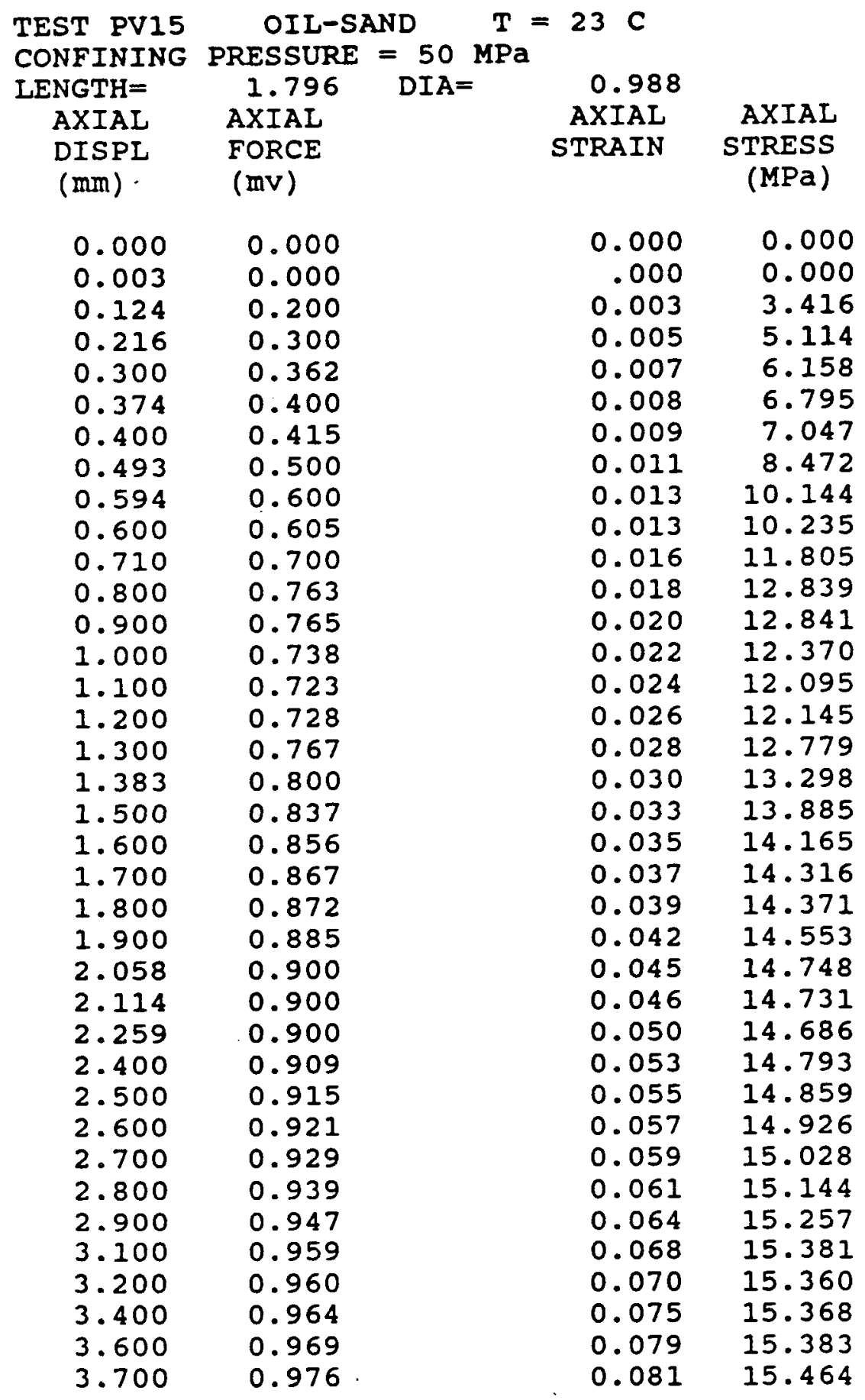


Figure $B-6$

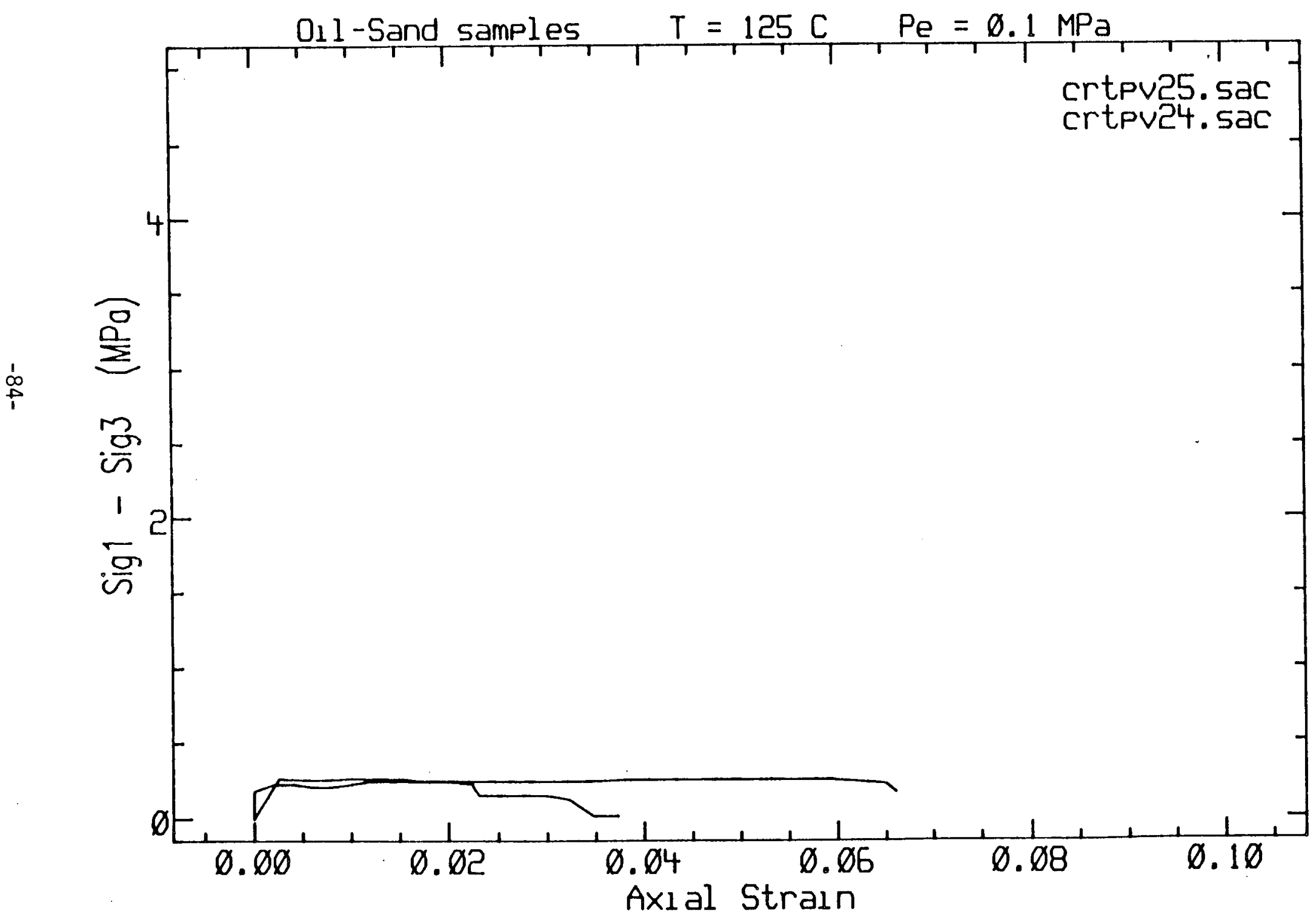




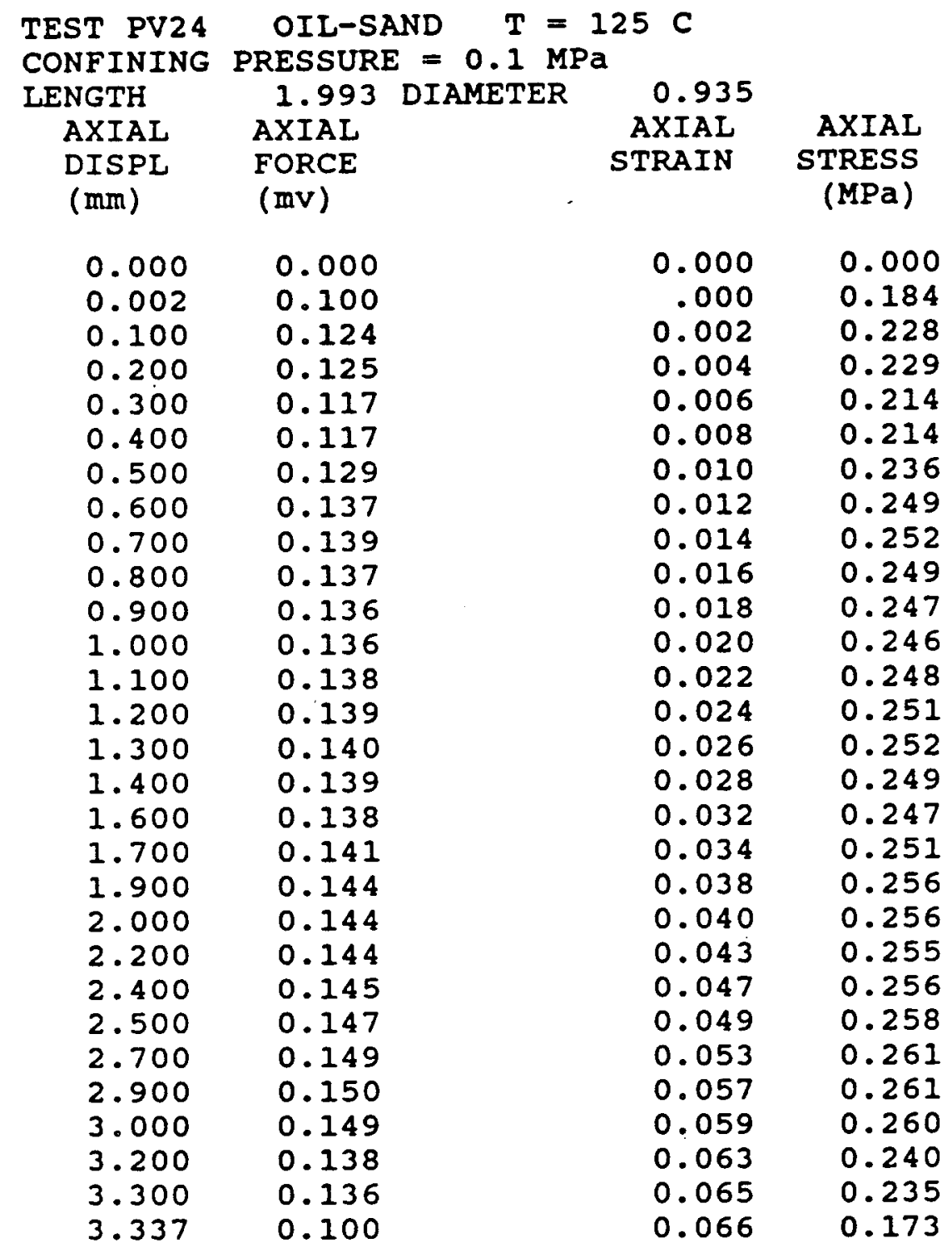




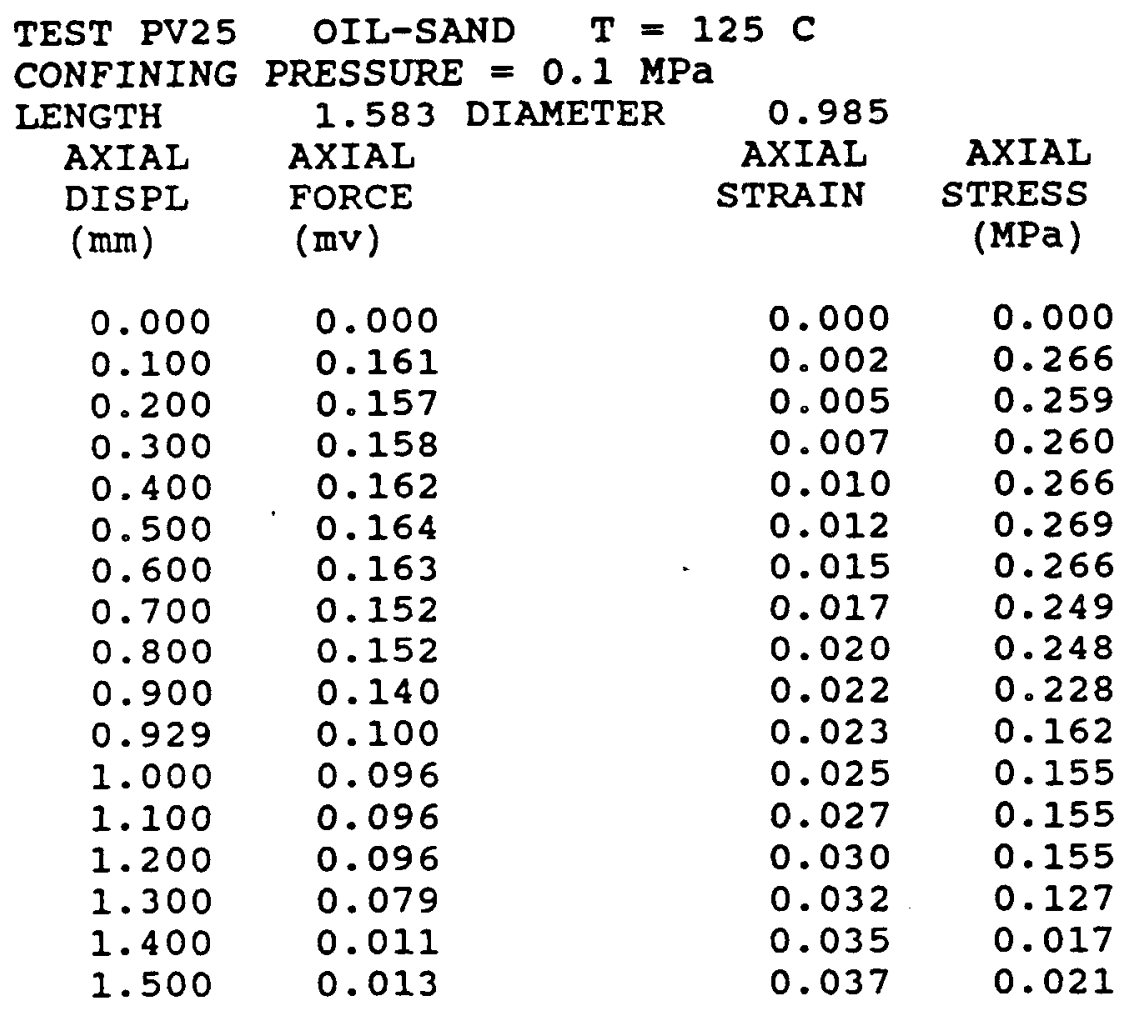


Figure B-7

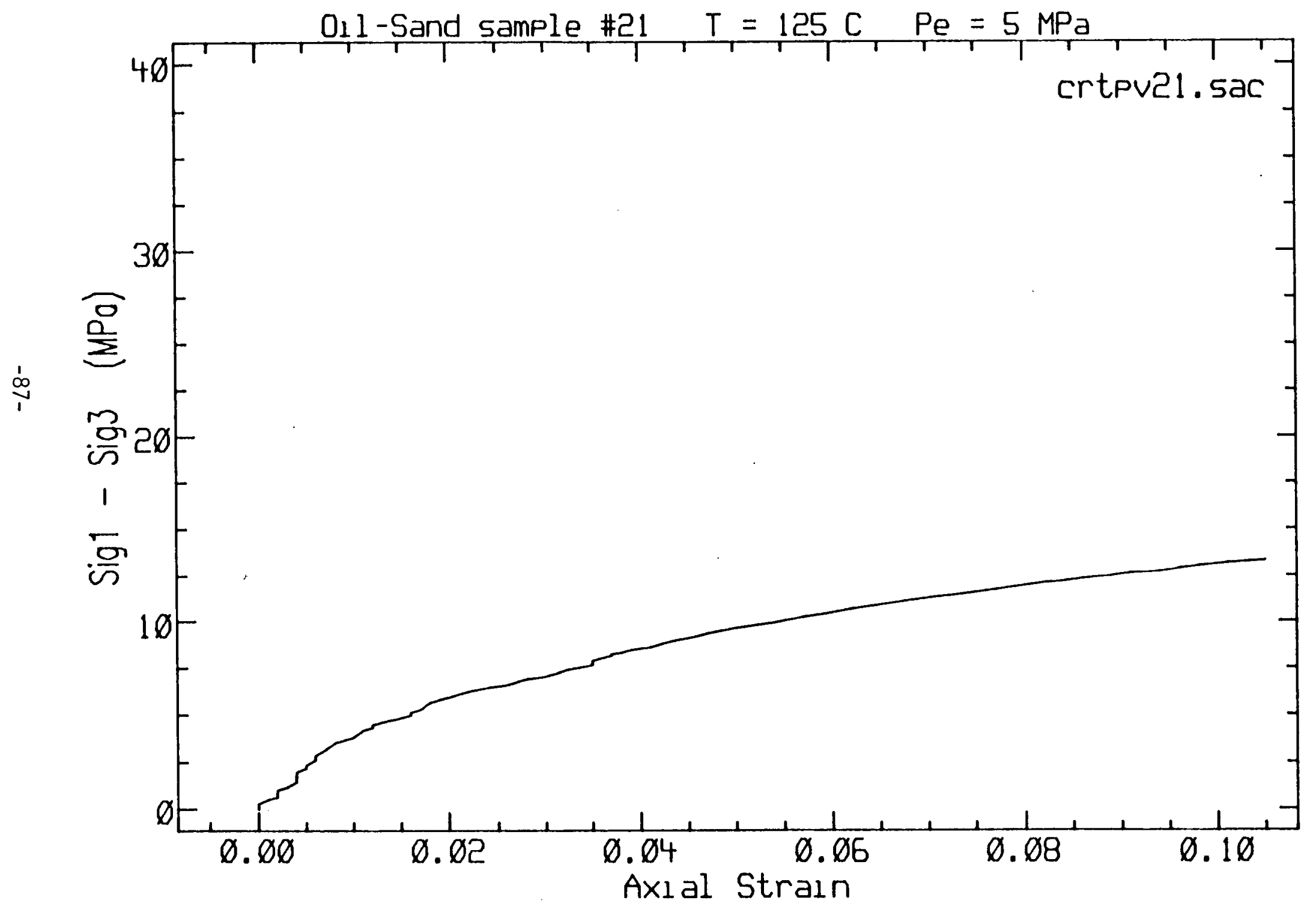




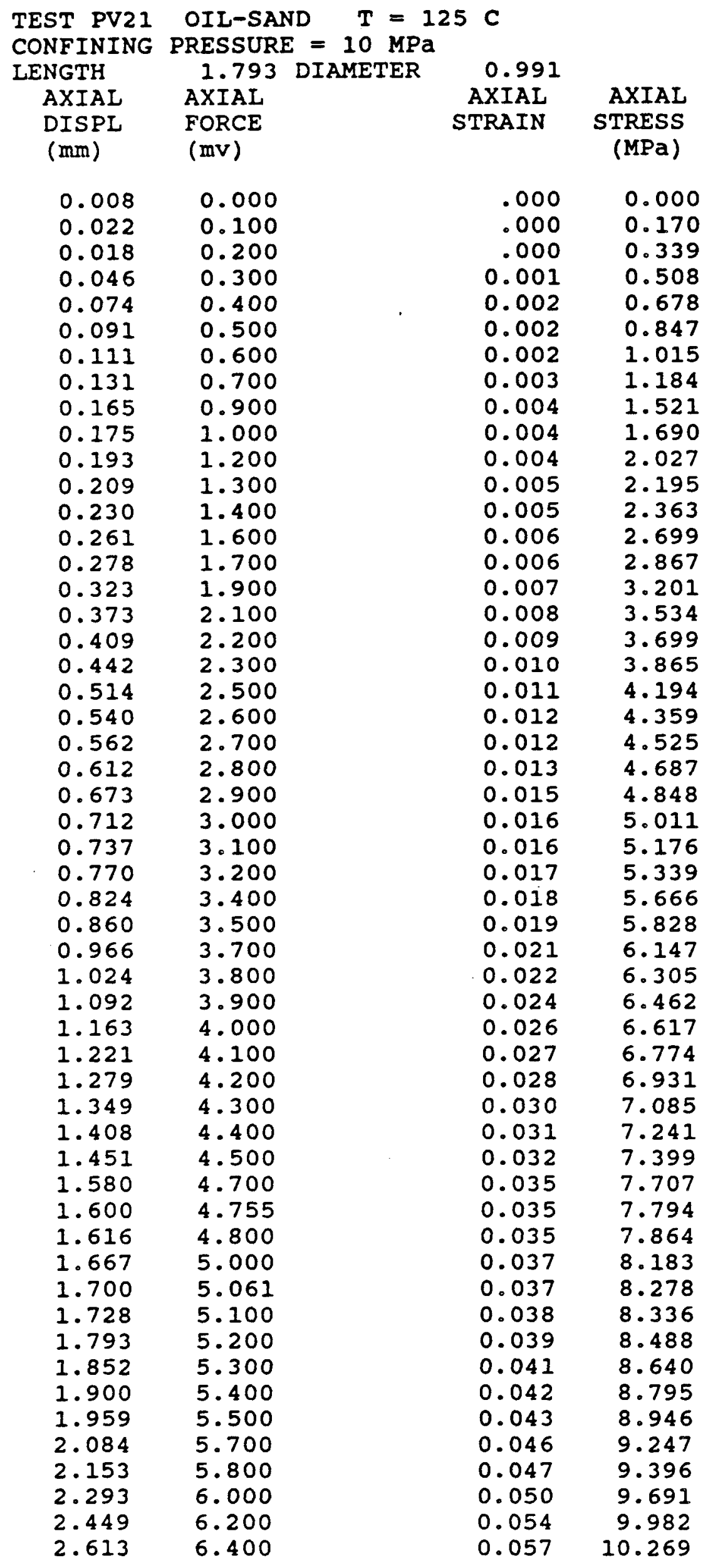




$\begin{array}{llll}2.683 & 6.500 & 0.059 & 10.414 \\ 2.830 & 6.700 & 0.062 & 10.702 \\ 2.931 & 6.800 & 0.064 & 10.839 \\ 3.103 & 7.000 & 0.068 & 11.118 \\ 3.190 & 7.100 & 0.070 & 11.257 \\ 3.381 & 7.300 & 0.074 & 11.529 \\ 3.473 & 7.400 & 0.076 & 11.665 \\ 3.639 & 7.600 & 0.080 & 11.940 \\ 3.742 & 7.700 & 0.082 & 12.072 \\ 3.843 & 7.800 & 0.084 & 12.203 \\ 3.938 & 7.900 & 0.086 & 12.336 \\ 4.038 & 8.000 & 0.089 & 12.467 \\ 4.150 & 8.100 & 0.091 & 12.594 \\ 4.267 & 8.200 & 0.094 & 12.720 \\ 4.380 & 8.300 & 0.096 & 12.846 \\ 4.482 & 8.400 & 0.098 & 12.974 \\ 4.583 & 8.500 & 0.101 & 13.102 \\ 4.685 & 8.600 & 0.103 & 13.229 \\ 4.700 & 8.611 & 0.103 & 13.242 \\ 4.800 & 8.650 & 0.105 & 13.277\end{array}$


Figure B-8

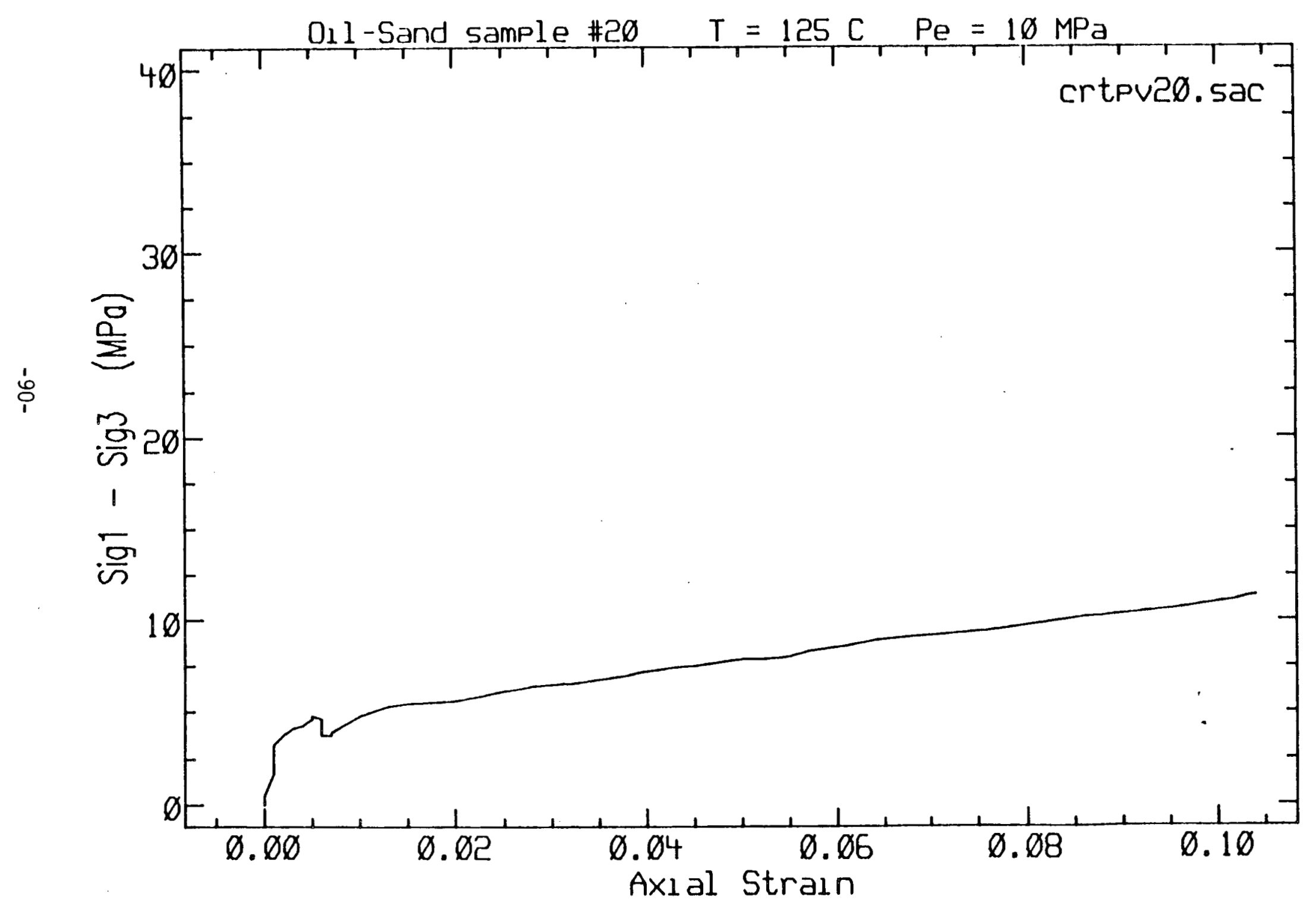




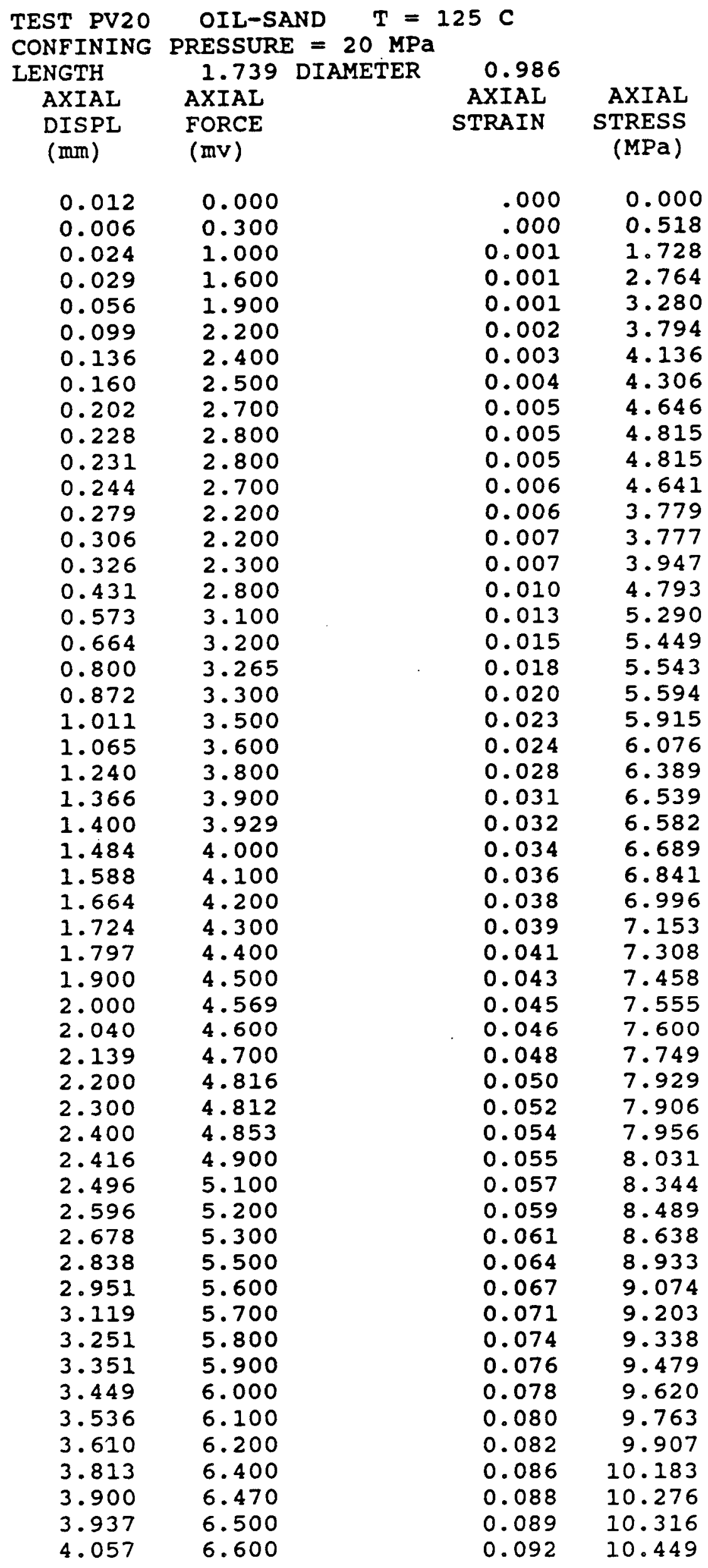




$\begin{array}{llll}4.230 & 6.800 & 0.096 & 10.727 \\ 4.322 & 6.900 & 0.098 & 10.864 \\ 4.409 & 7.000 & 0.100 & 11.002 \\ 4.498 & 7.100 & 0.102 & 11.138 \\ 4.500 & 7.103 & 0.102 & 11.143 \\ 4.567 & 7.200 & 0.103 & 11.279 \\ 4.600 & 7.262 & 0.104 & 11.369\end{array}$


Figure B-9

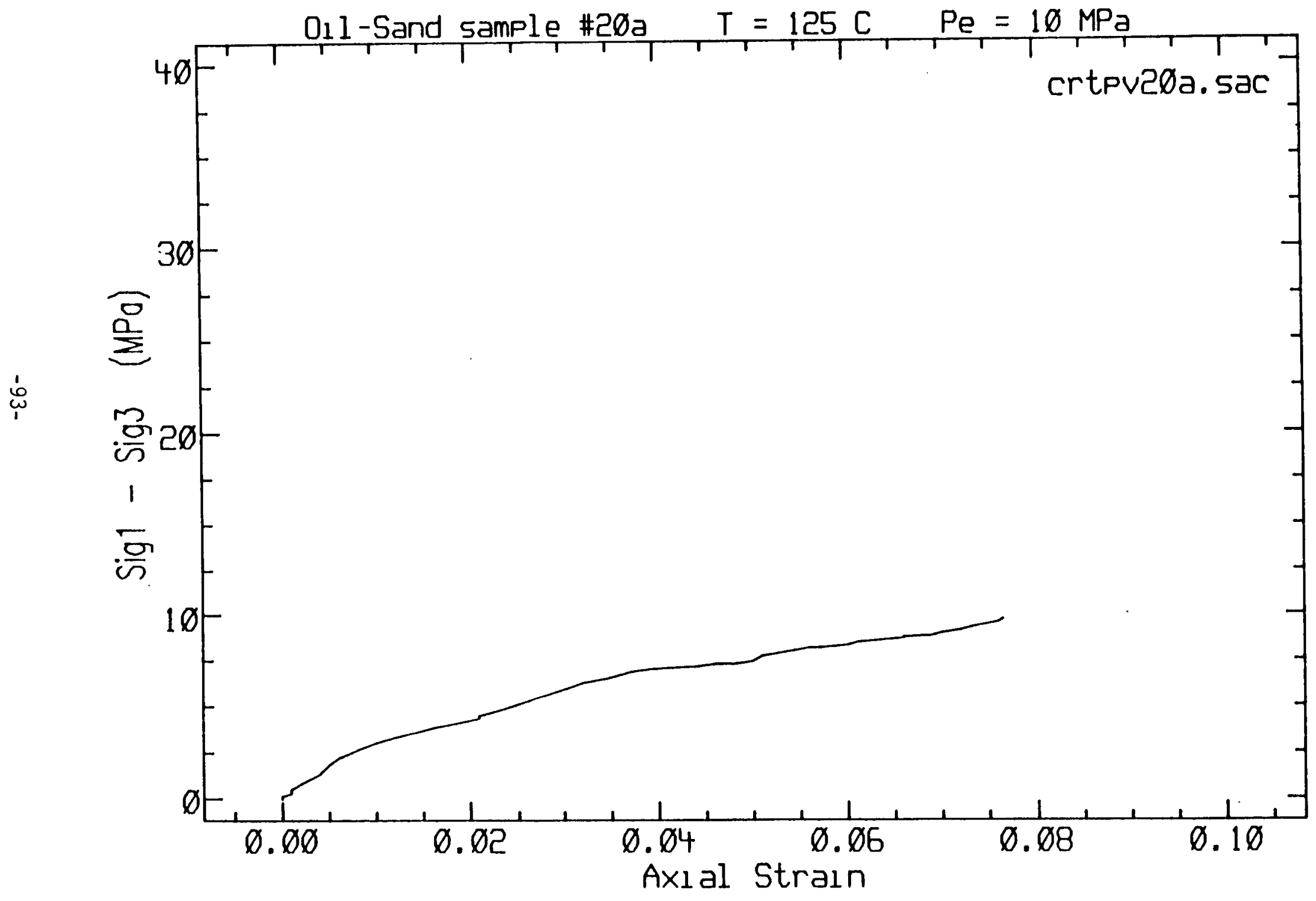




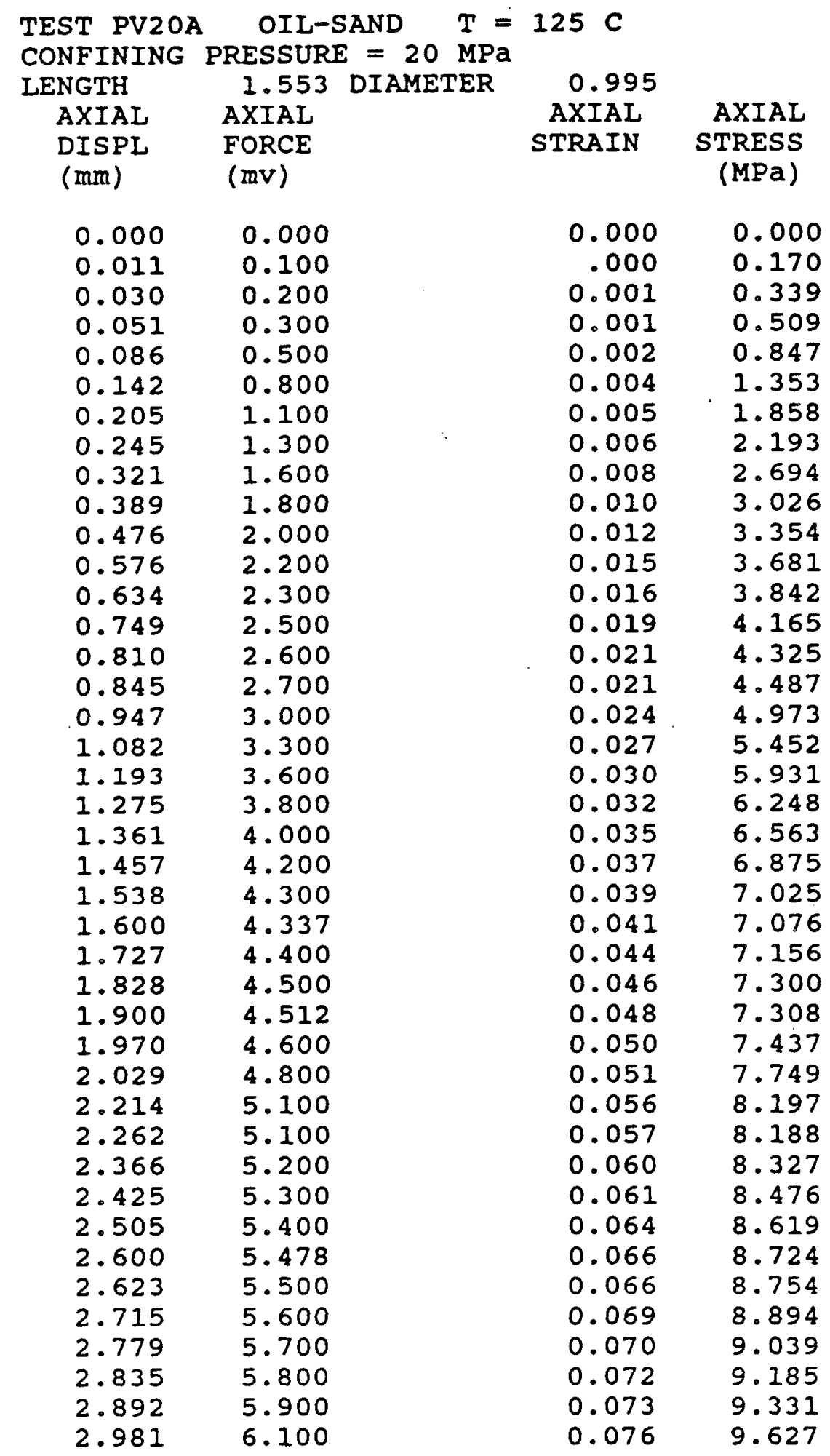


Figure B-10

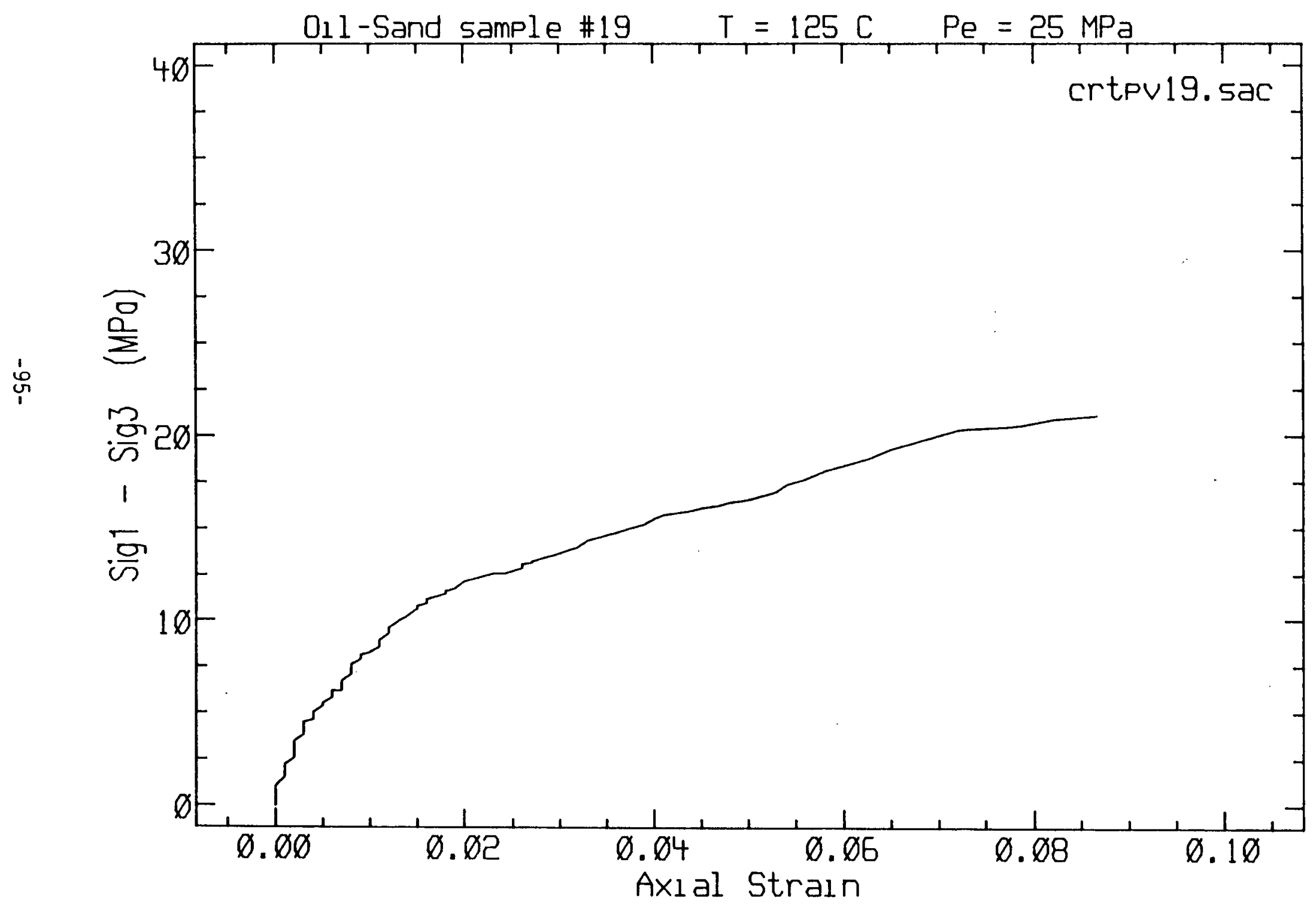




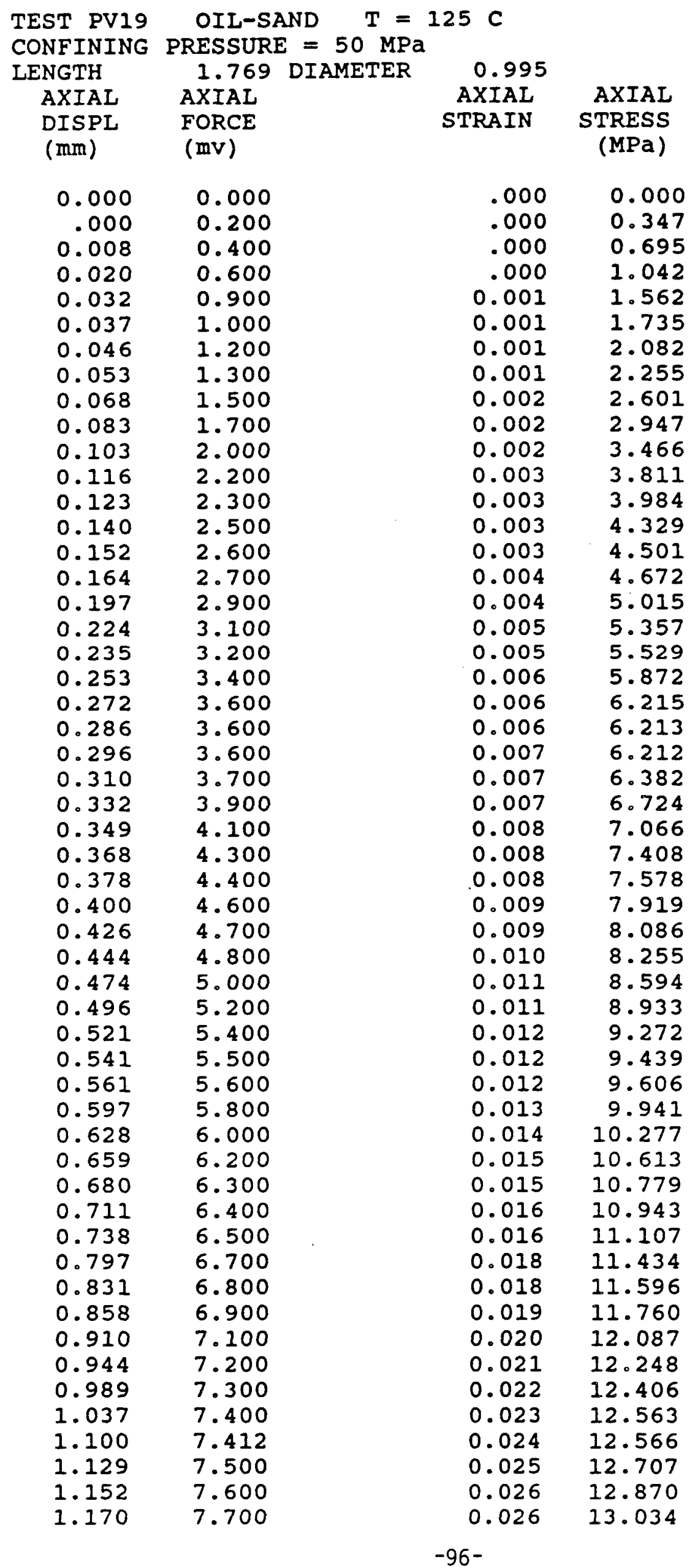




$\begin{array}{llll}1.200 & 7.756 & 0.027 & 13.120 \\ 1.222 & 7.800 & 0.027 & 13.189 \\ 1.269 & 7.900 & 0.028 & 13.344 \\ 1.341 & 8.100 & 0.030 & 13.661 \\ 1.378 & 8.200 & 0.031 & 13.818 \\ 1.417 & 8.300 & 0.032 & 13.975 \\ 1.495 & 8.500 & 0.033 & 14.288 \\ 1.583 & 8.700 & 0.035 & 14.596 \\ 1.623 & 8.800 & 0.036 & 14.751 \\ 1.662 & 8.900 & 0.037 & 14.907 \\ 1.739 & 9.100 & 0.039 & 15.216 \\ 1.817 & 9.300 & 0.040 & 15.525 \\ 1.863 & 9.400 & 0.041 & 15.676 \\ 1.981 & 9.600 & 0.044 & 15.969 \\ 2.039 & 9.700 & 0.045 & 16.116 \\ 2.116 & 9.800 & 0.047 & 16.255 \\ 2.175 & 9.900 & 0.048 & 16.401 \\ 2.231 & 10.000 & 0.050 & 16.547 \\ 2.284 & 10.100 & 0.051 & 16.694 \\ 2.371 & 10.300 & 0.053 & 16.993 \\ 2.439 & 10.500 & 0.054 & 17.298 \\ 2.514 & 10.700 & 0.056 & 17.599 \\ 2.624 & 11.000 & 0.058 & 18.051 \\ 2.670 & 11.100 & 0.059 & 18.198 \\ 2.706 & 11.200 & 0.060 & 18.348 \\ 2.810 & 11.500 & 0.063 & 18.798 \\ 2.916 & 11.800 & 0.065 & 19.246 \\ 3.035 & 12.100 & 0.068 & 19.686 \\ 3.127 & 12.300 & 0.070 & 19.973 \\ 3.224 & 12.500 & 0.072 & 20.257 \\ 3.294 & 12.600 & 0.073 & 20.389 \\ 3.400 & 12.660 & 0.076 & 20.442 \\ 3.493 & 12.700 & 0.078 & 20.467 \\ 3.571 & 12.800 & 0.079 & 20.595 \\ 3.682 & 13.000 & 0.082 & 20.869 \\ 3.889 & 13.200 & 0.087 & 21.100\end{array}$


Figure B-11

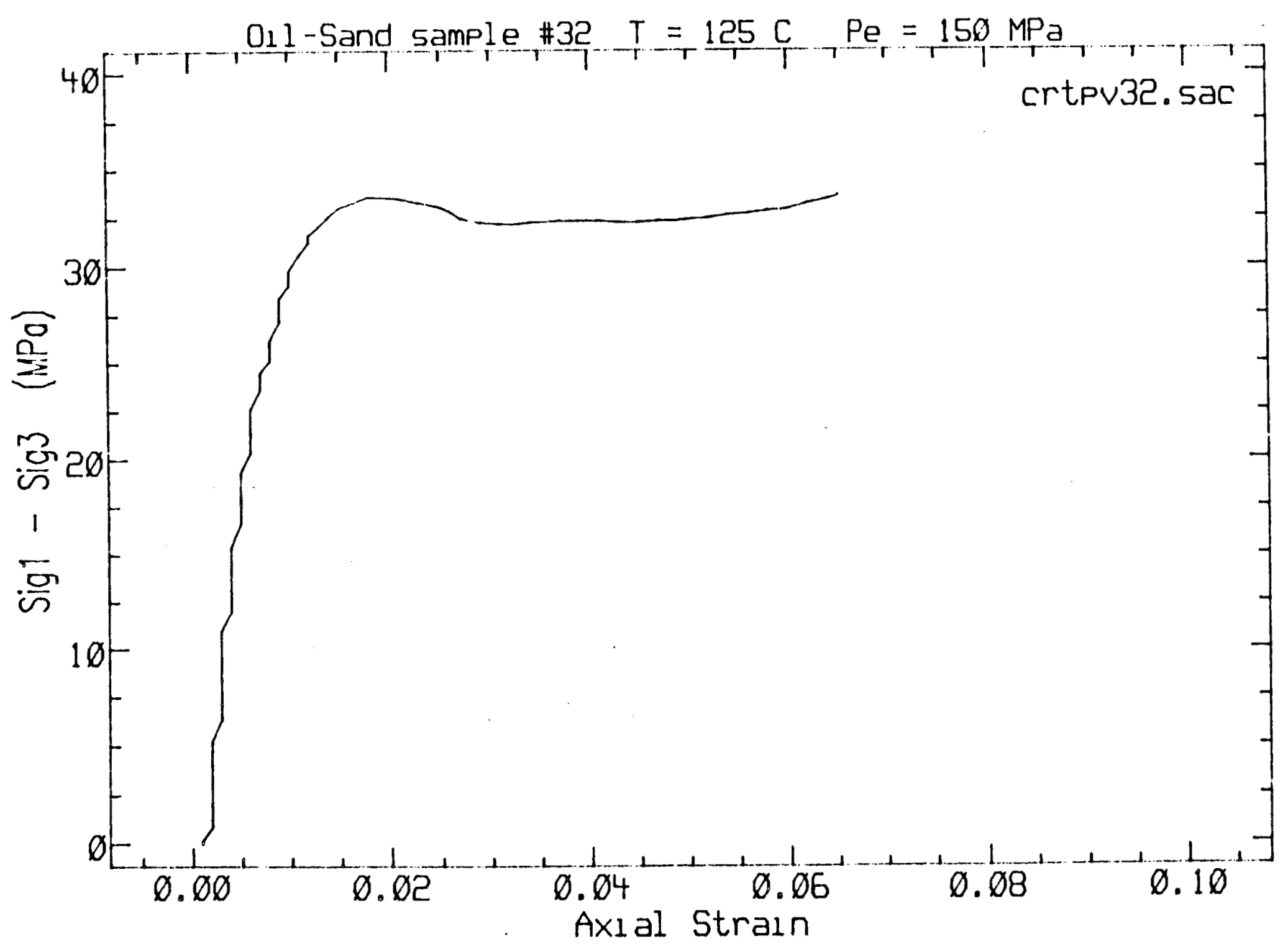




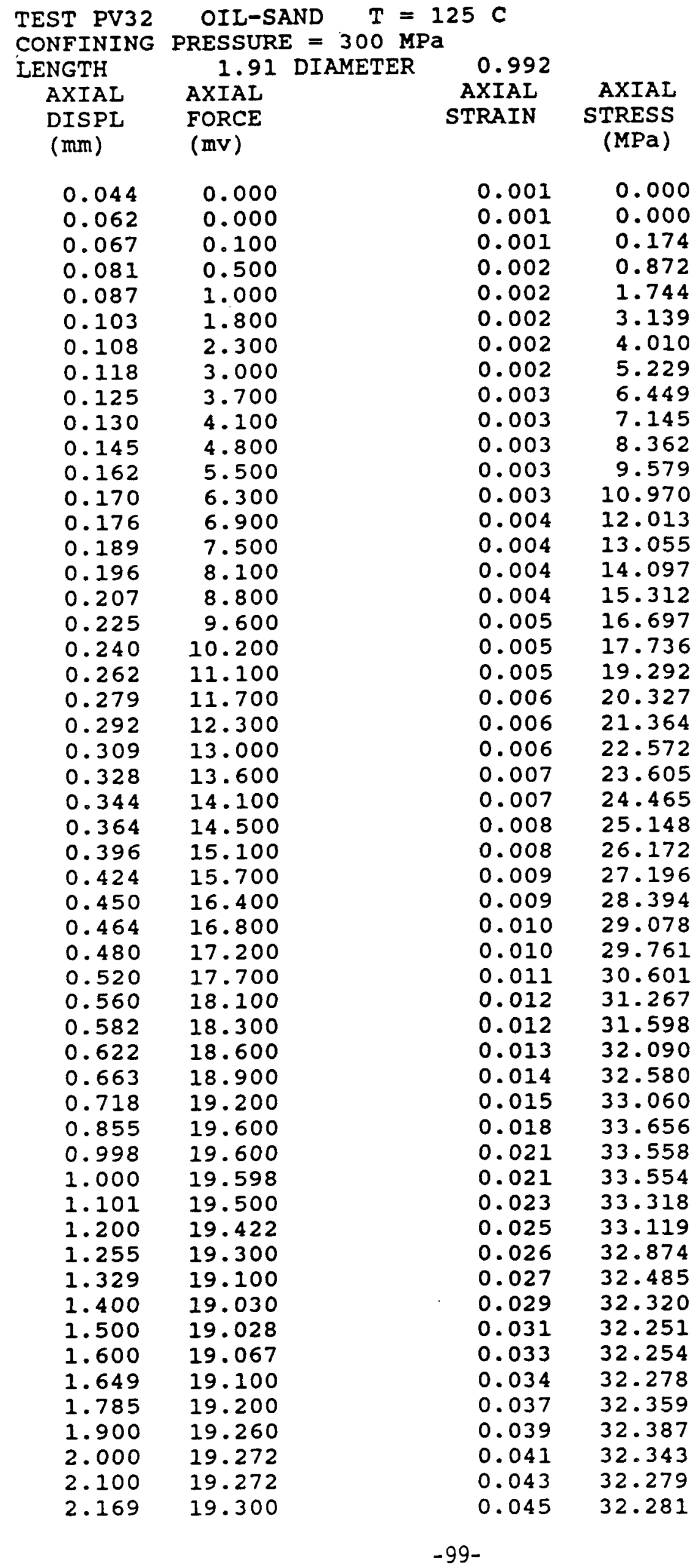




$\begin{array}{llll}2.200 & 19.319 & 0.045 & 32.293 \\ 2.300 & 19.384 & 0.047 & 32.338 \\ 2.323 & 19.400 & 0.048 & 32.350 \\ 2.400 & 19.448 & 0.049 & 32.381 \\ 2.448 & 19.500 & 0.050 & 32.437 \\ 2.530 & 19.600 & 0.052 & 32.551 \\ 2.621 & 19.700 & 0.054 & 32.659 \\ 2.720 & 19.800 & 0.056 & 32.761 \\ 2.822 & 19.900 & 0.058 & 32.862 \\ 2.900 & 19.980 & 0.060 & 32.943 \\ 2.914 & 20.000 & 0.060 & 32.967 \\ 3.014 & 20.200 & 0.062 & 33.233 \\ 3.114 & 20.400 & 0.064 & 33.497 \\ 3.157 & 20.500 & 0.065 & 33.632\end{array}$


Figure $B-12$

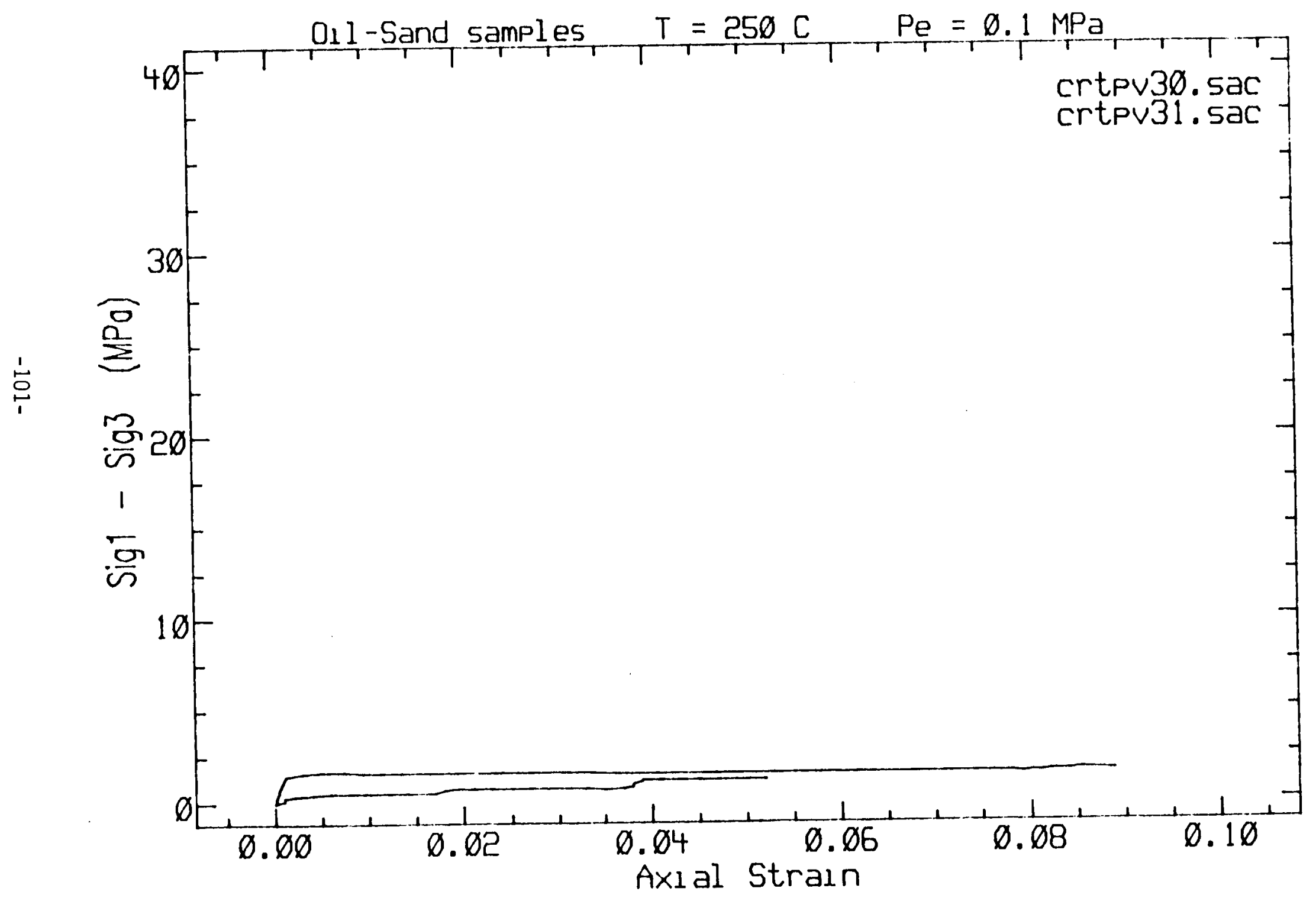




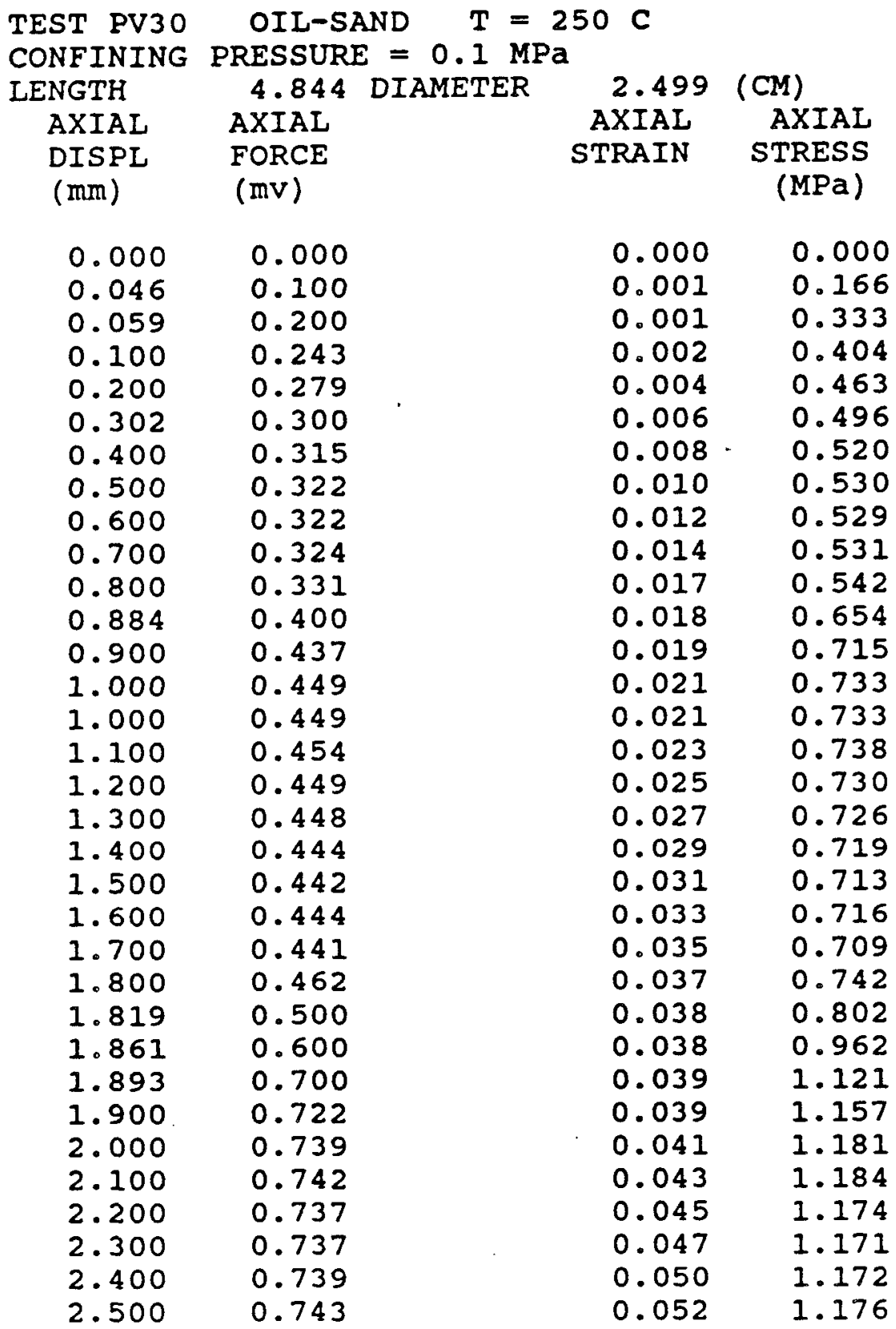




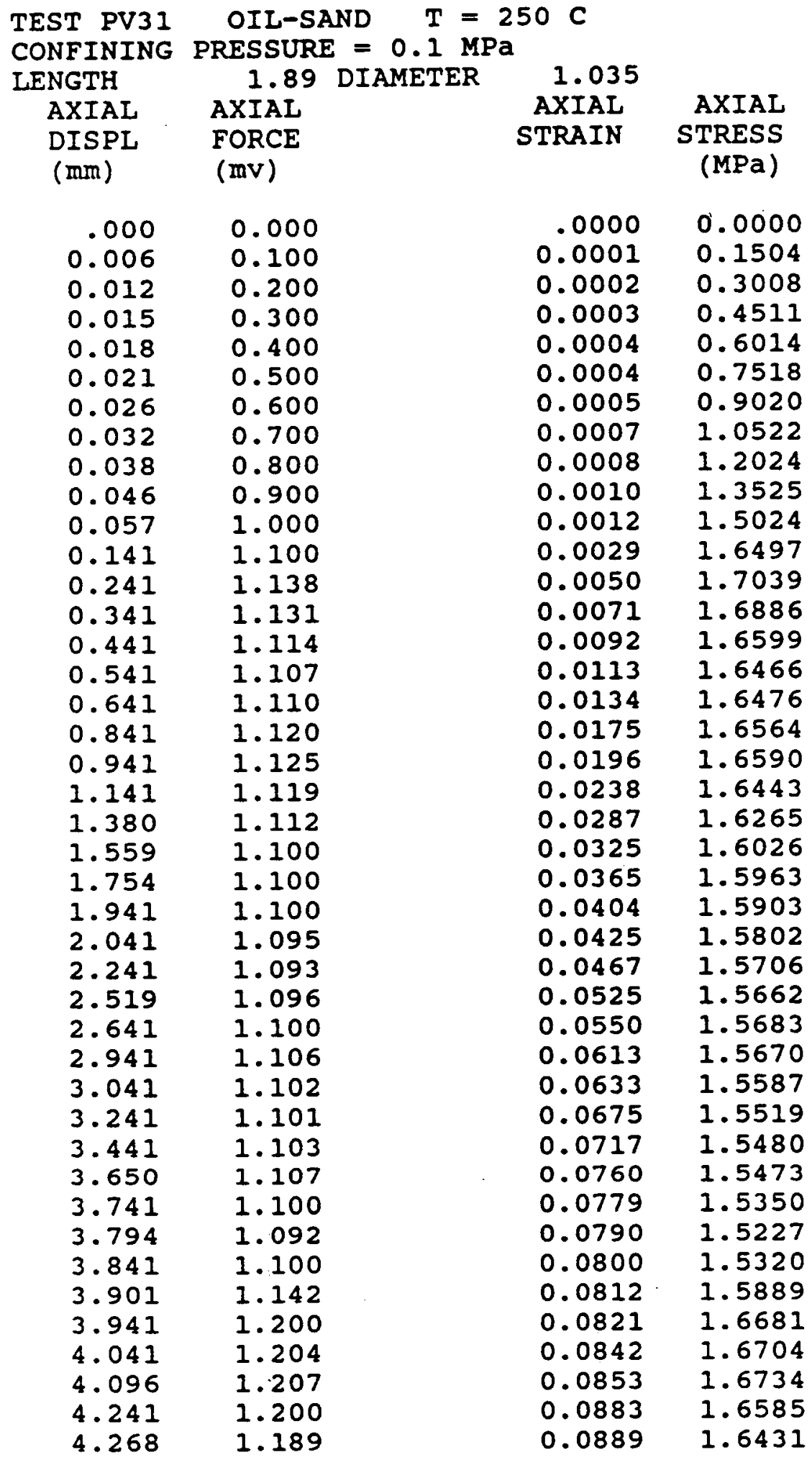




\section{APPENDIX C}

STRESS-STRAIN PLOTS AND TABULATED DATA FOR TRIAXIAL TESTS CONDUCTED ON SHALE SAMPLES

$-104-$ 
FILE INDEX VZSHALE.WKS - TRIAXIAL TESTS ON SHALE

SAMPLE

PV5

PV4

PV14

PV13

PV12

PV2

PVI

PV9

PV7

PV2 3

PV22

PV26

PV27

PV27A

PV27B

PV3 3

PV2 8

PV29

PV3 4
PC

0.1

0.1

2

10

20

50

300

0.1

0.1

20

. 50

50

50

300

0.1

0.1
DEPTH TEMP C LOCATION WKS

$23 \mathrm{~J} 1$

$23 \mathrm{SI}$

23 ABI

23 AKI

23 ATl

23 BBI

23 BKI

23 BTI

$125 \mathrm{~A} 200$

125 BD200

$125 \mathrm{~J} 200$

$125 \mathrm{BO} 200$

$125 \mathrm{~S} 200$

125 AB200

125 AK200

125 AT200

$250 \AA 400$

$250 \mathrm{~K} 400$

$-105-$ 
Figure $\mathrm{C}-1$

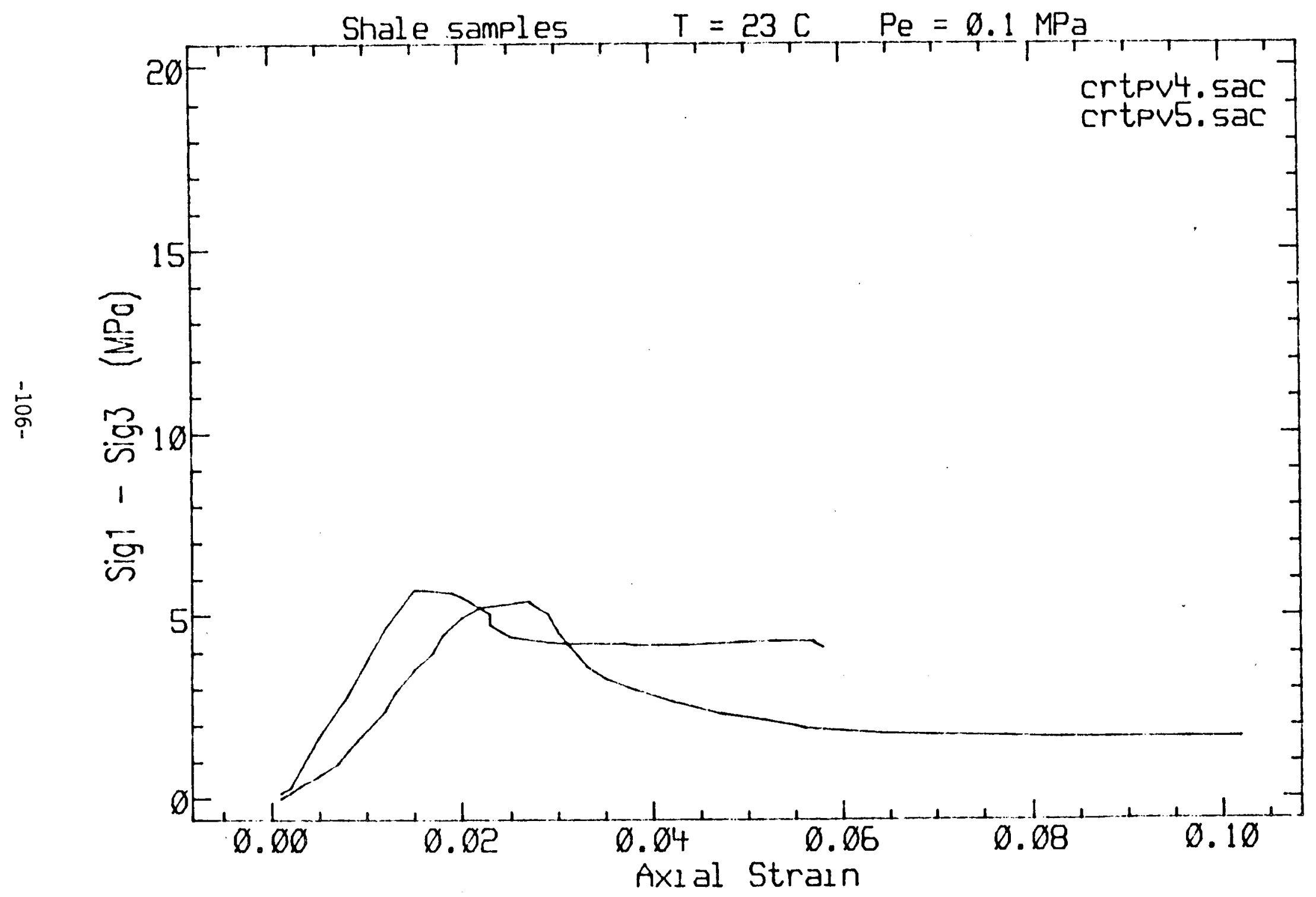




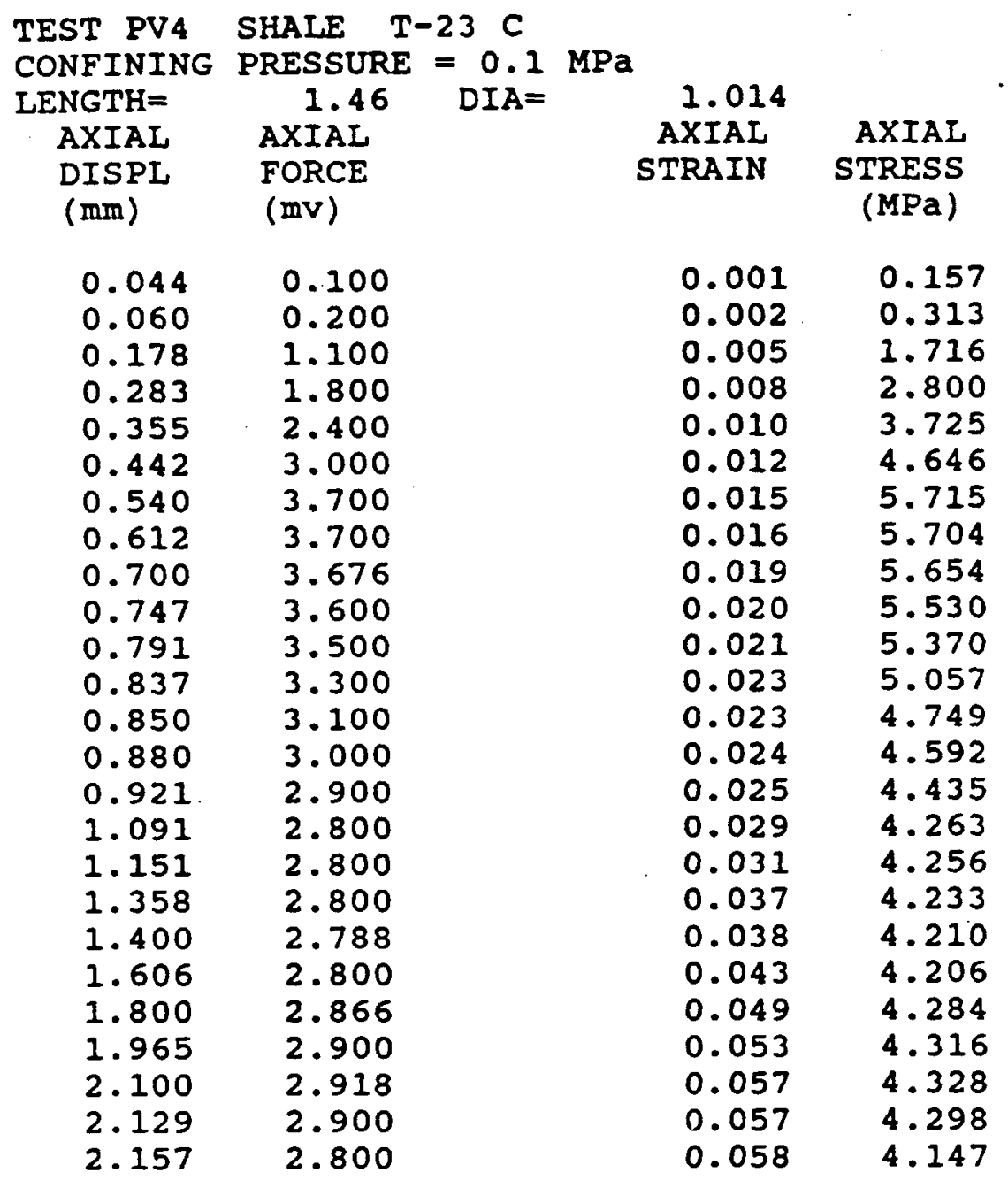




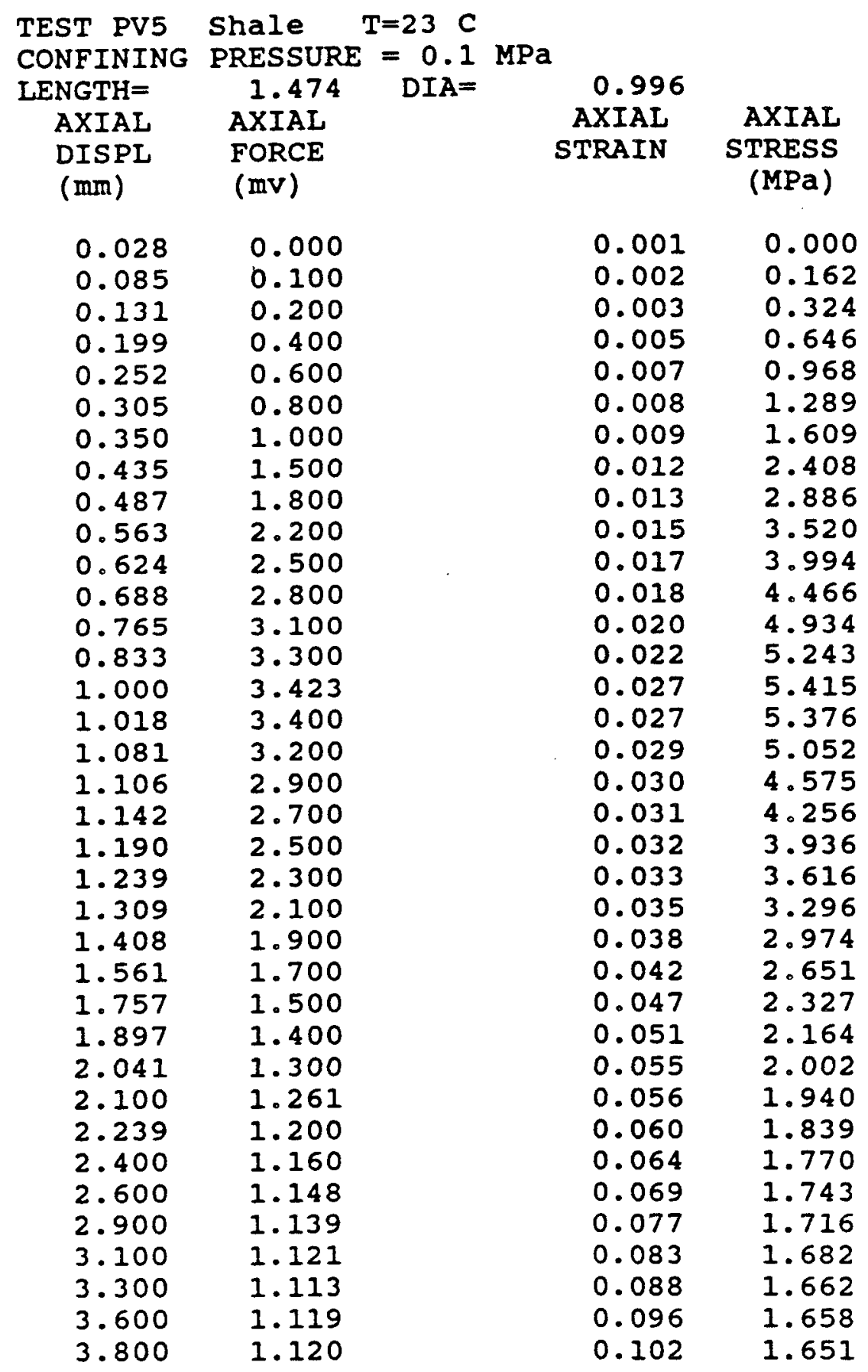


Figure $\mathrm{C}-2$

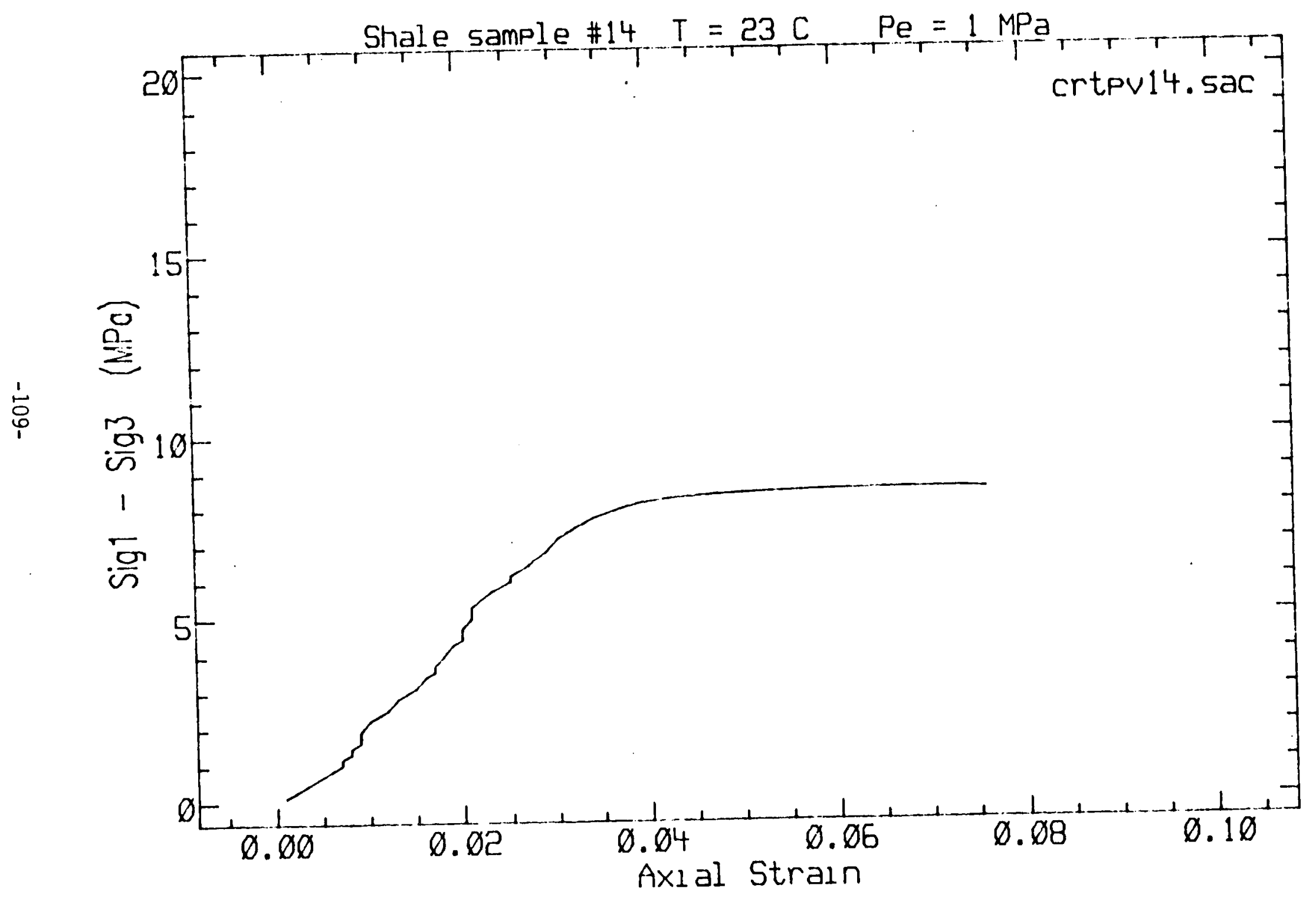




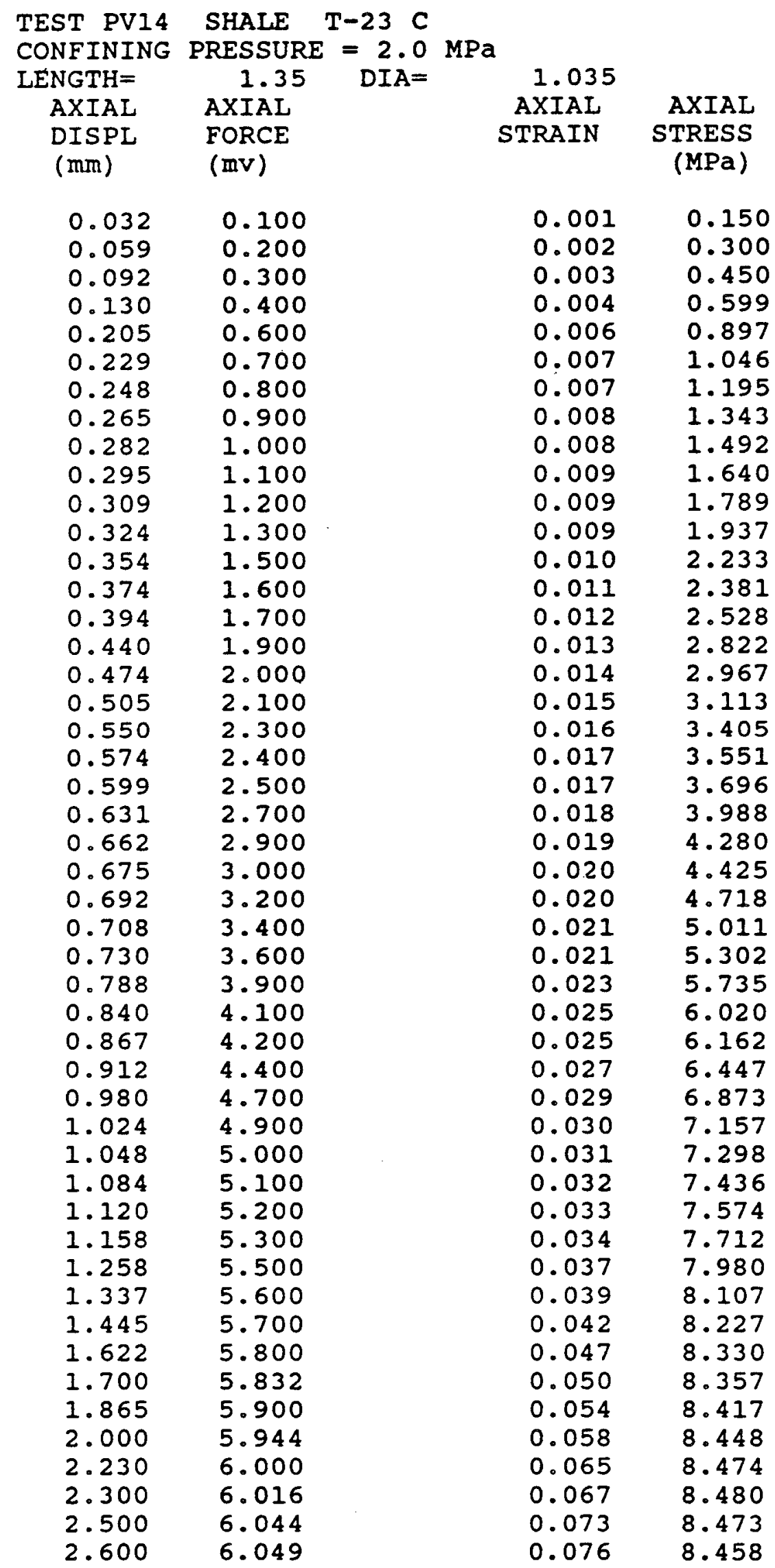


Figure $\mathrm{C}-3$

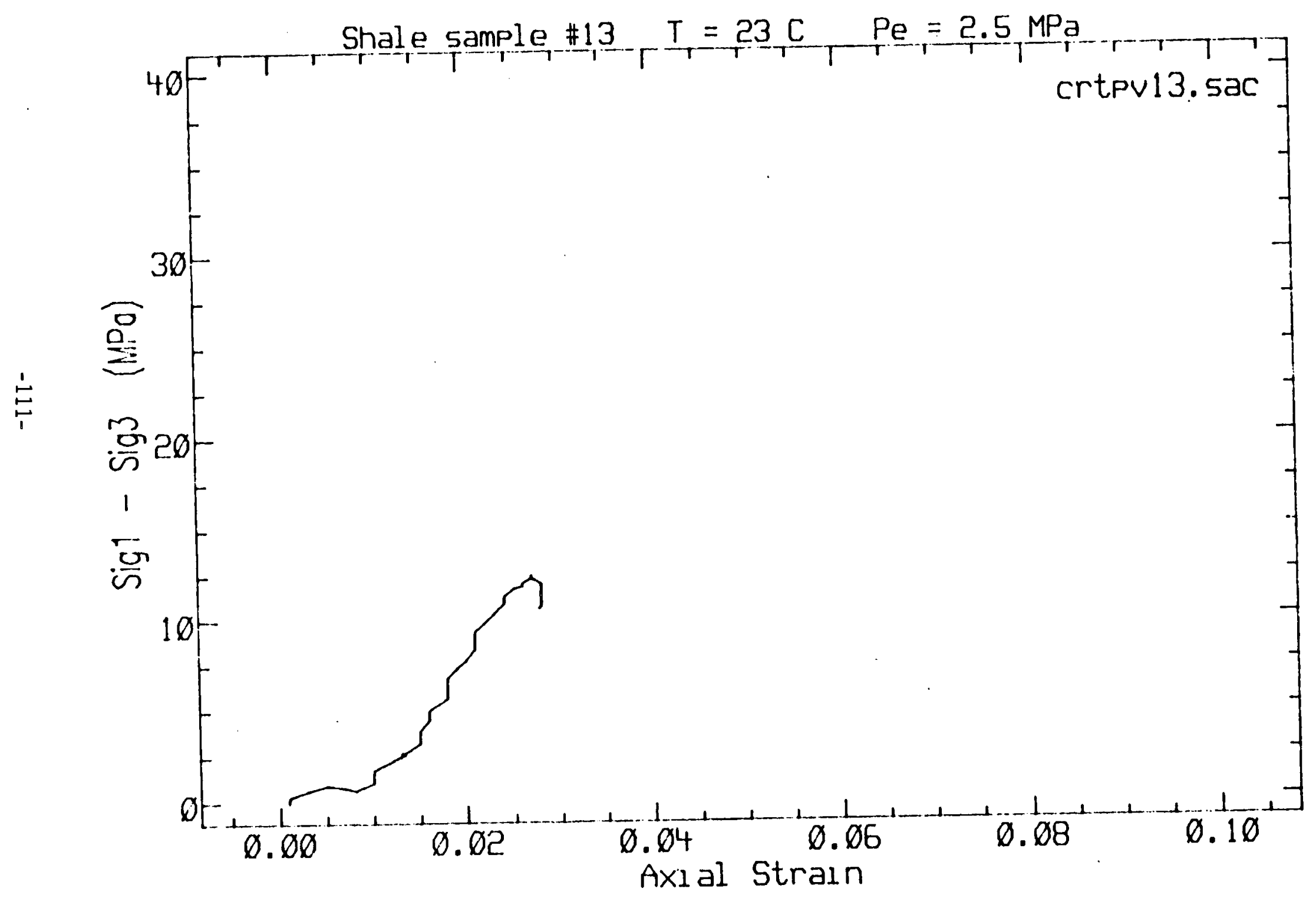




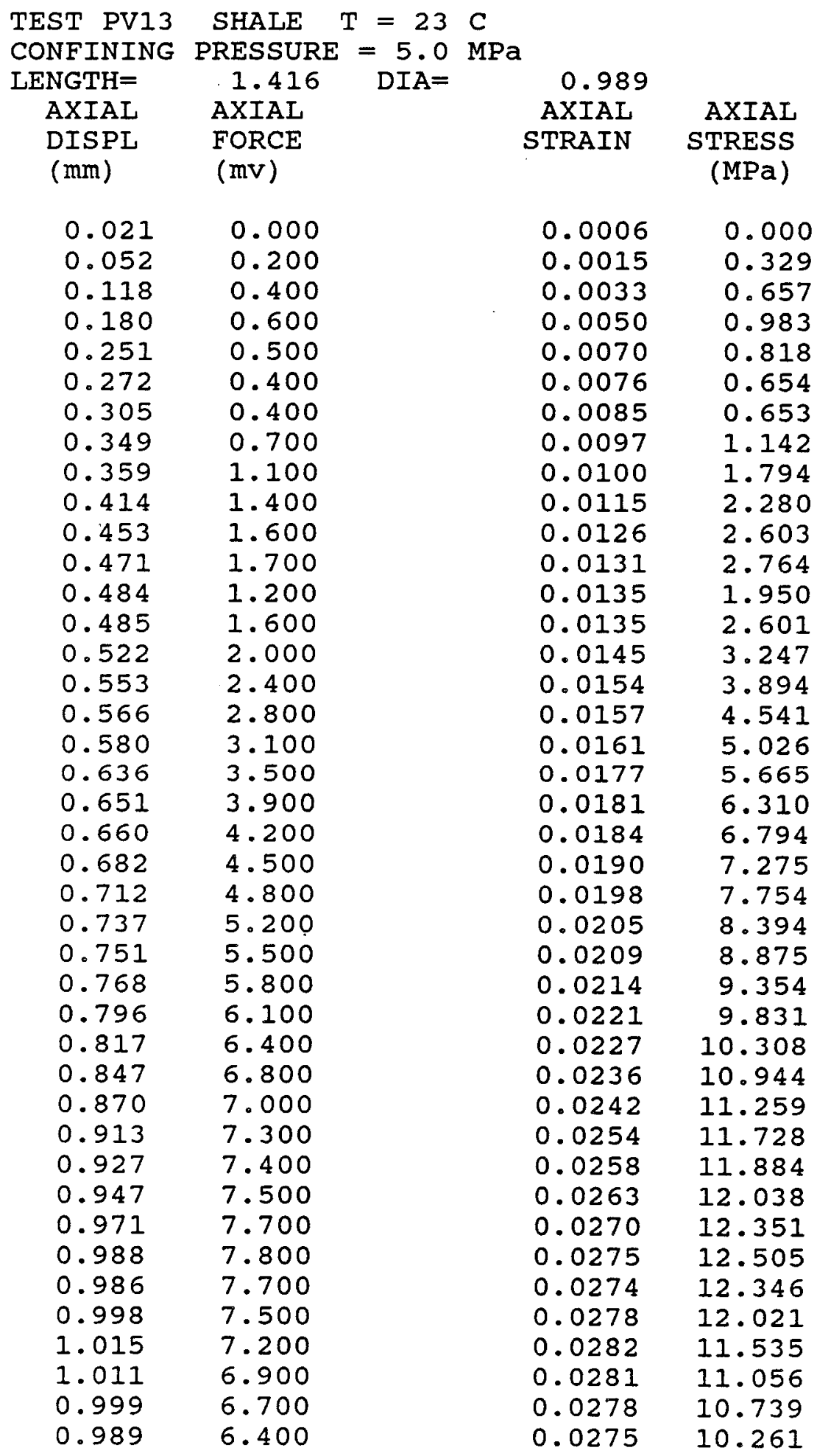


Figure $\mathrm{C}-4$

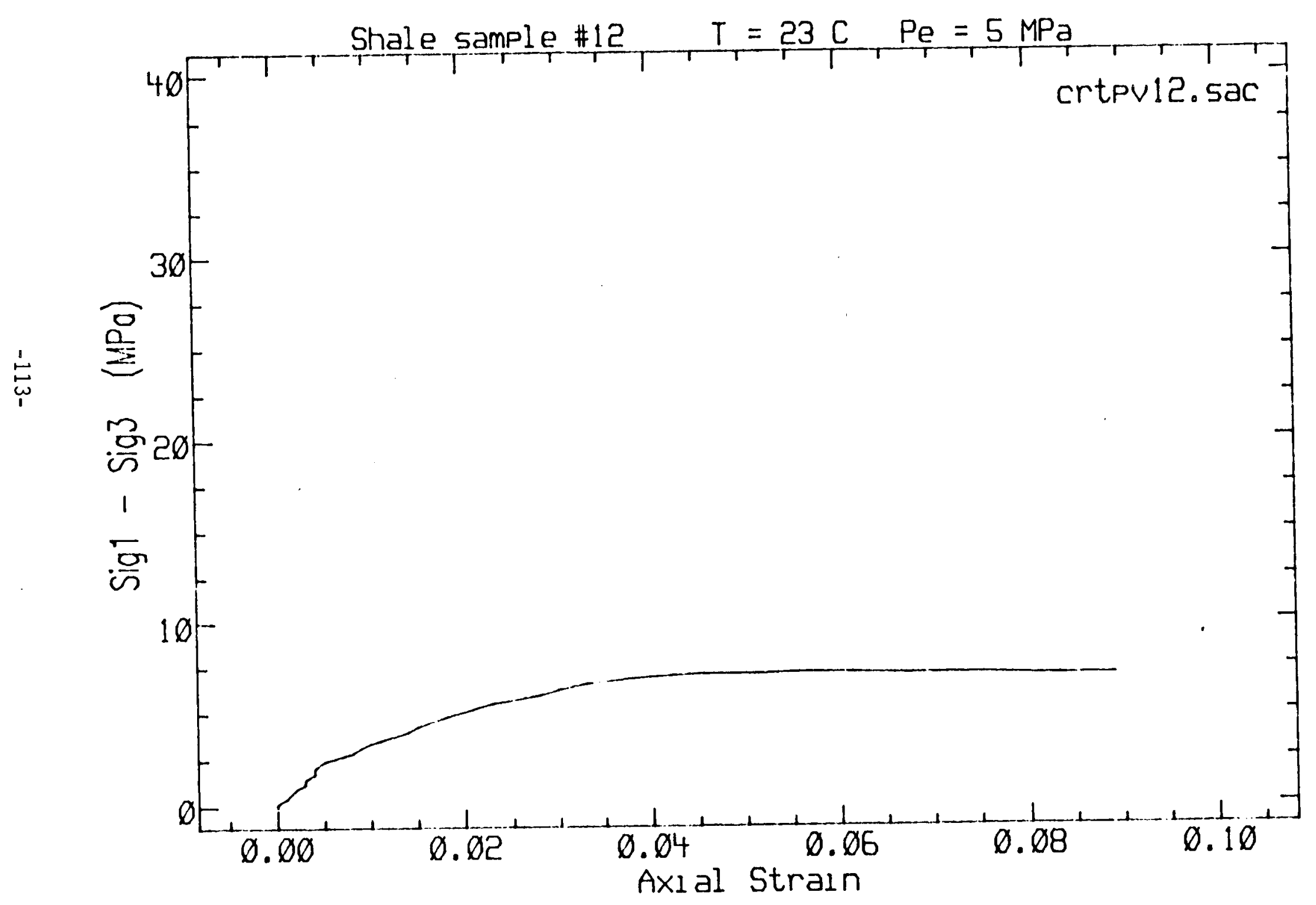




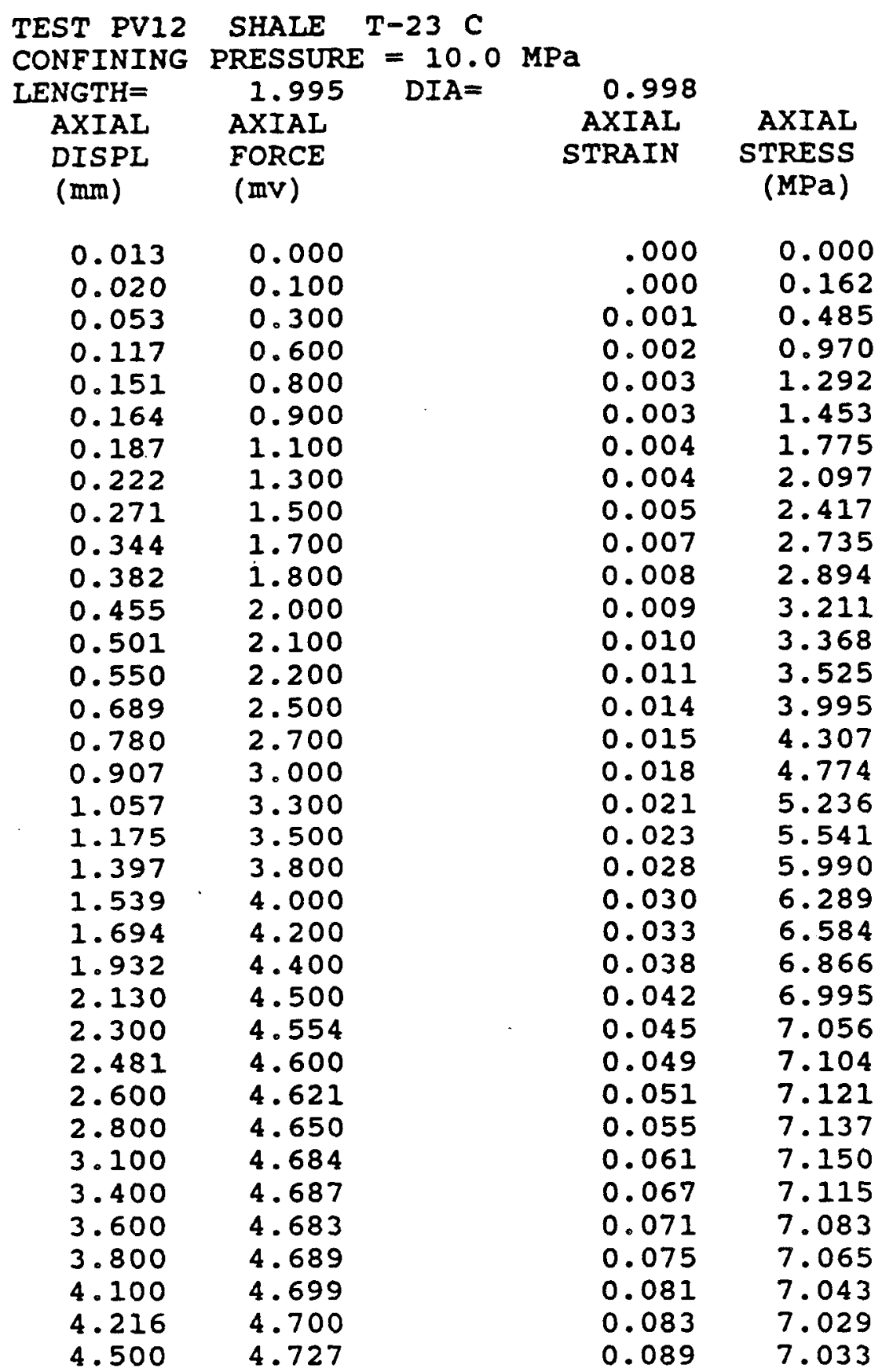


Figure C-5

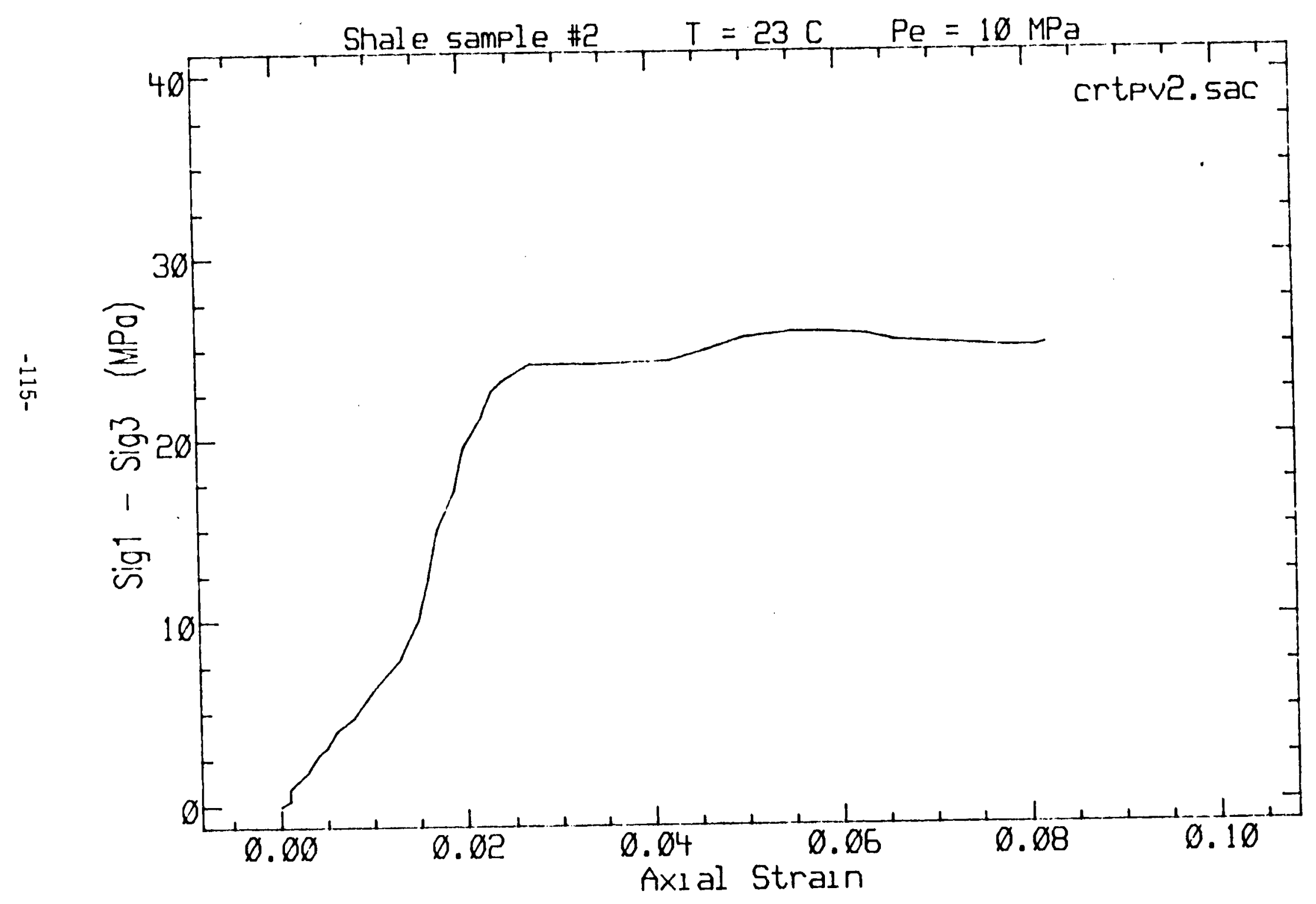




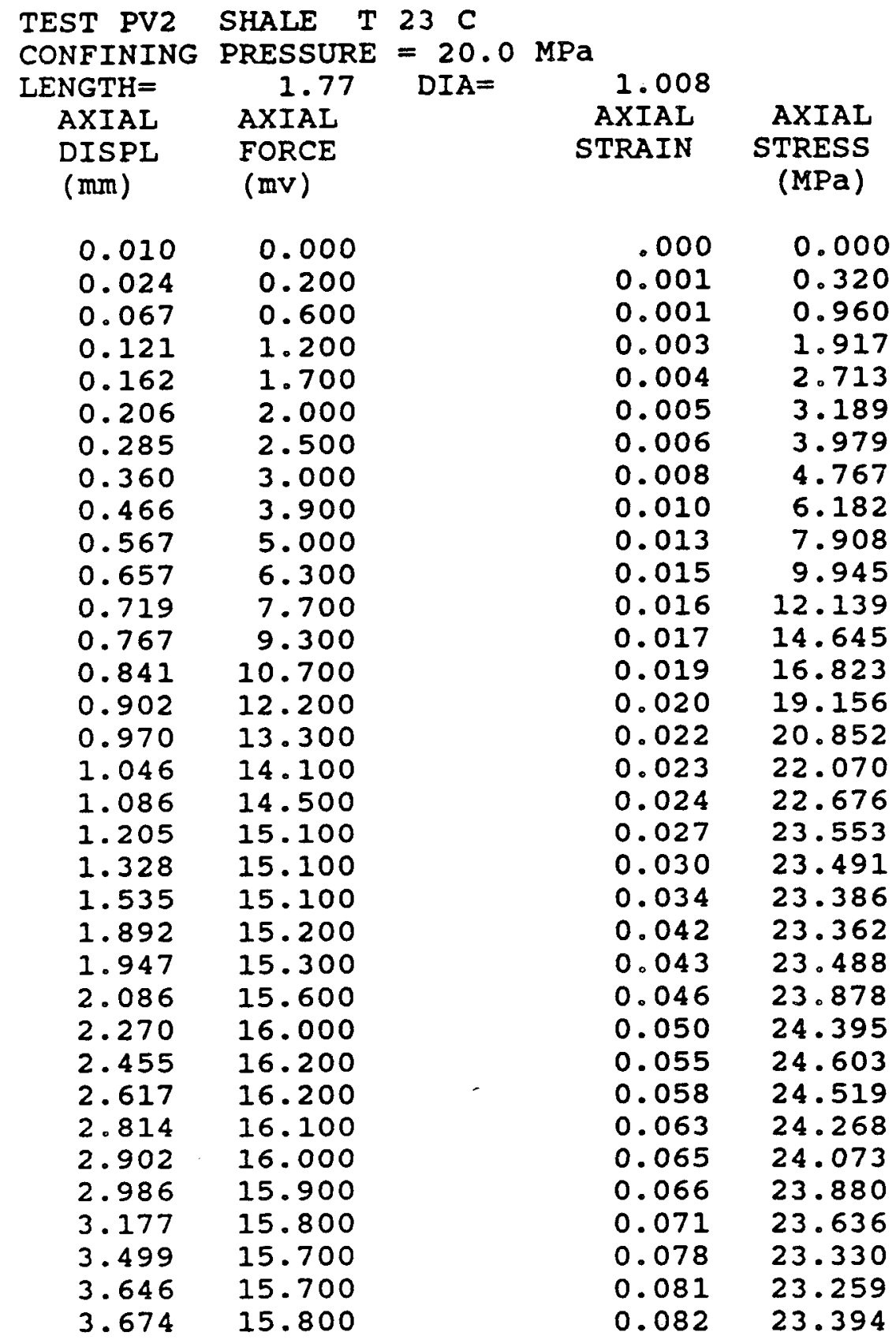


Figure $C-6$

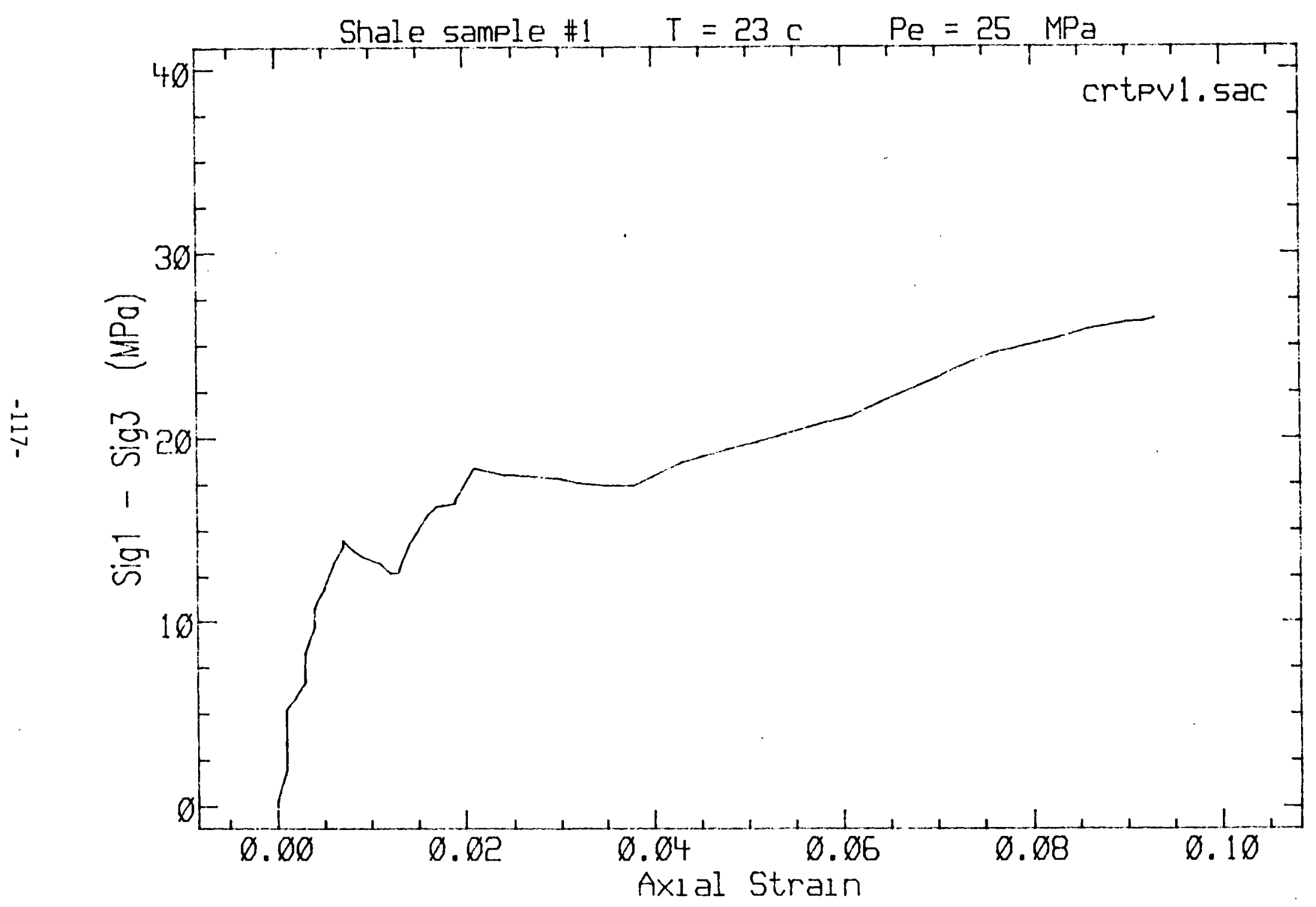




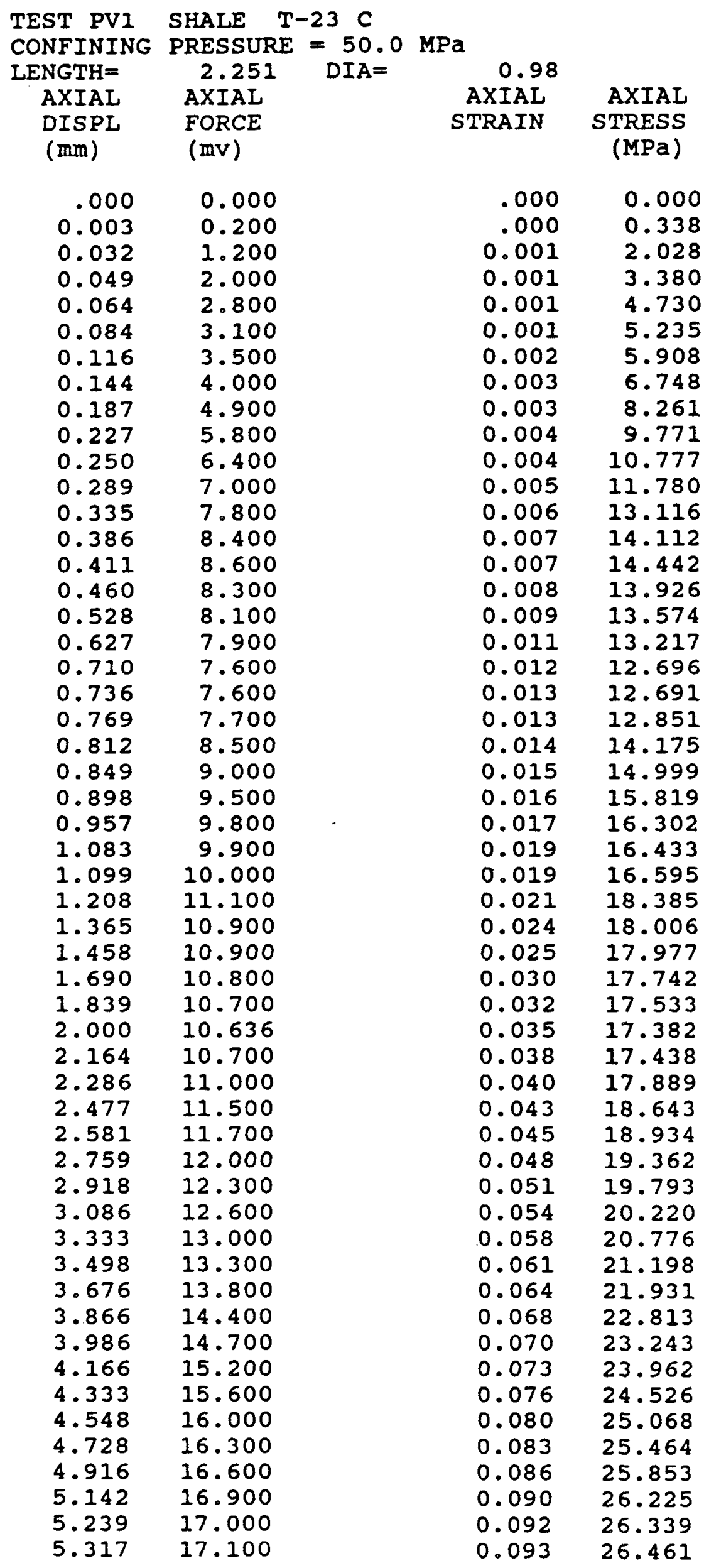


Figure $\mathrm{C}-7$

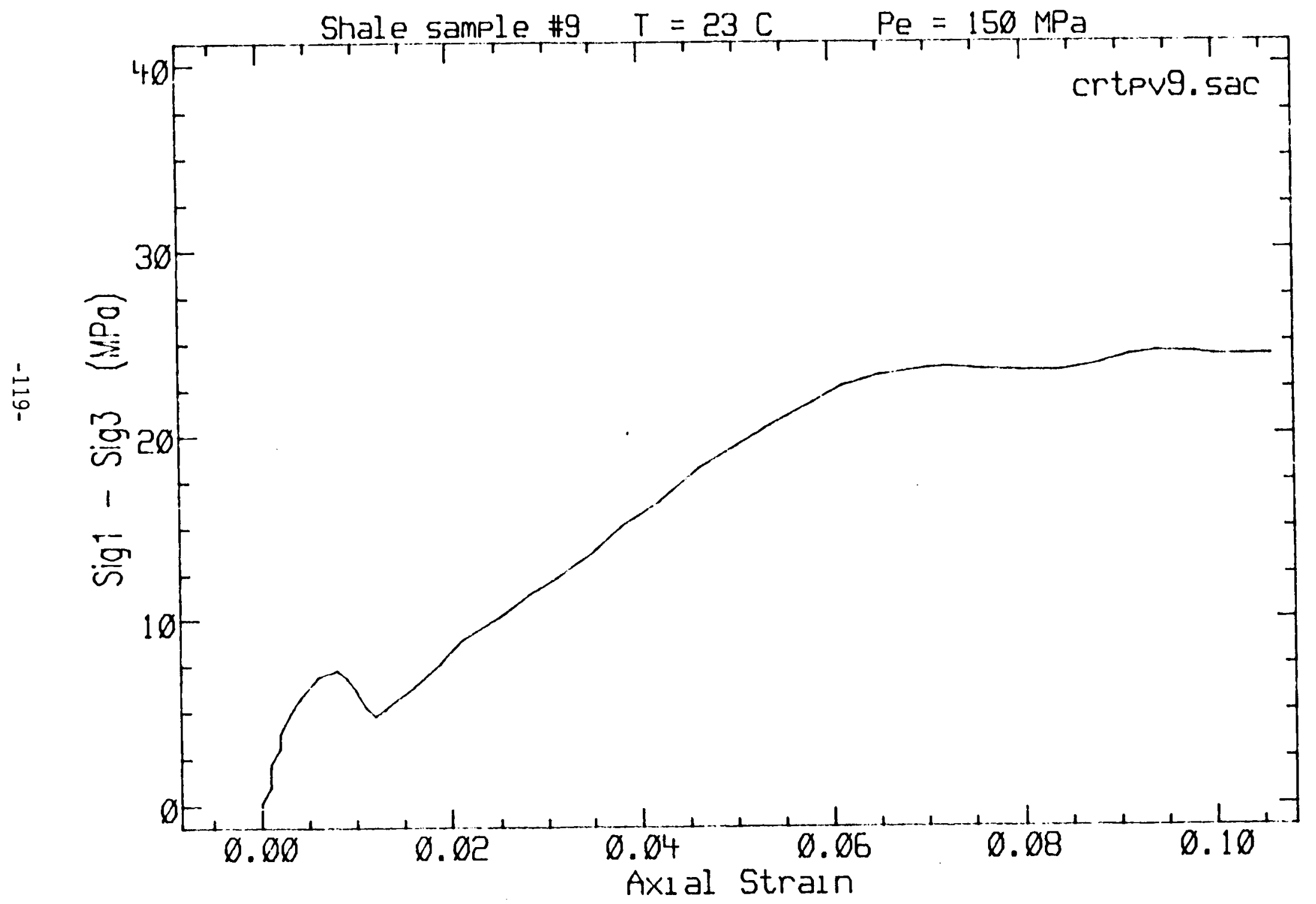




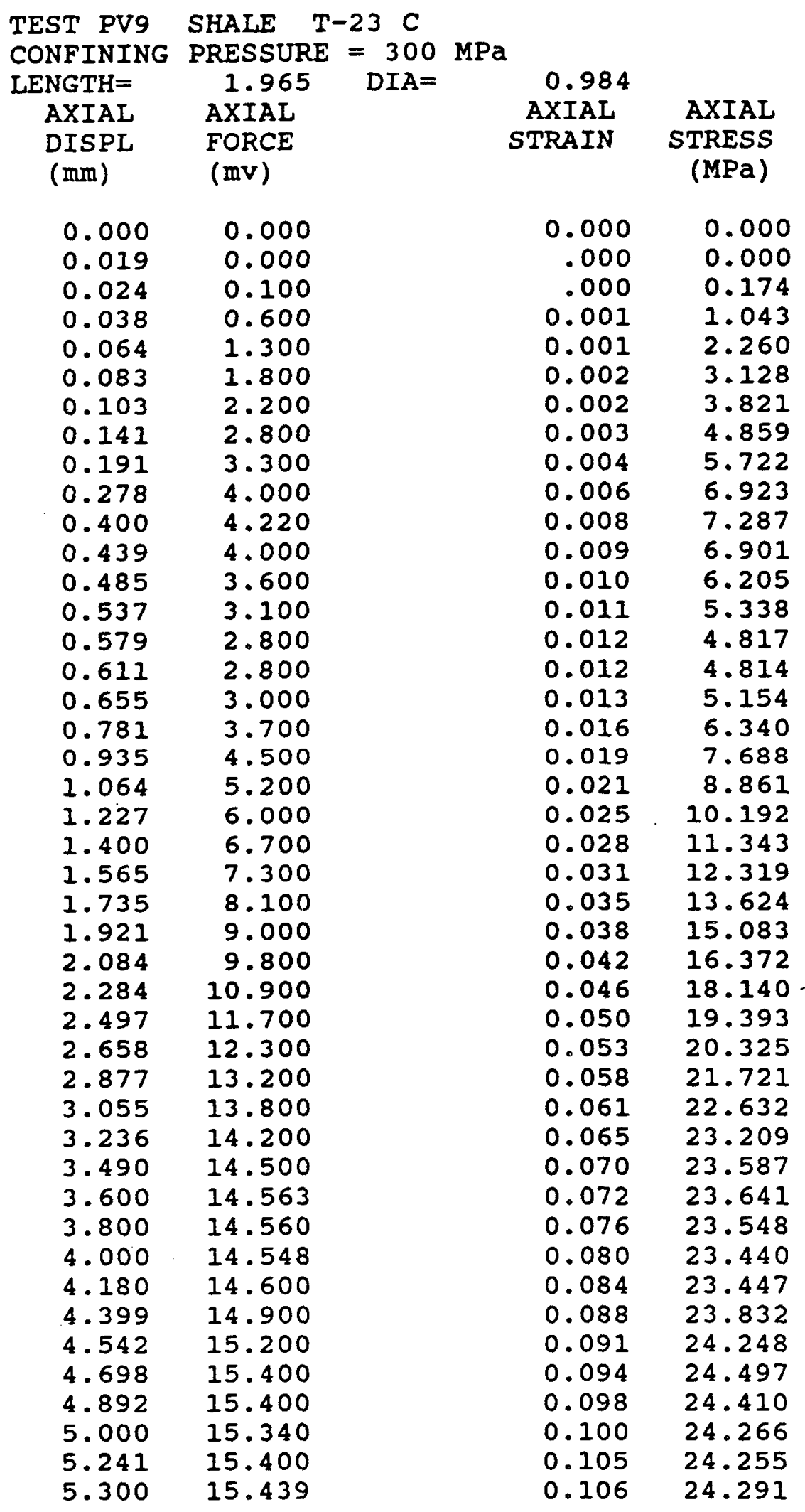


Figure $\mathrm{C}-8$

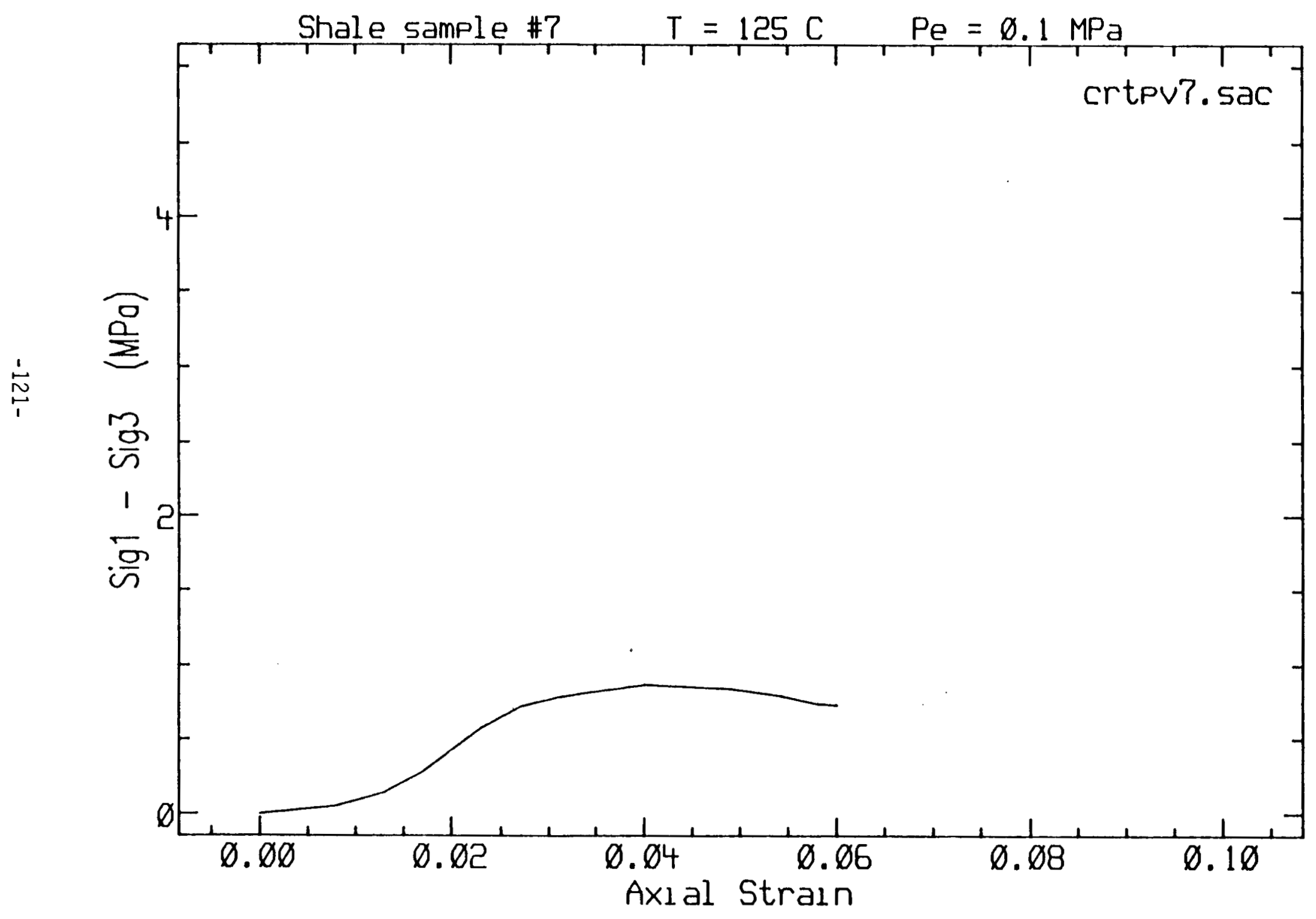




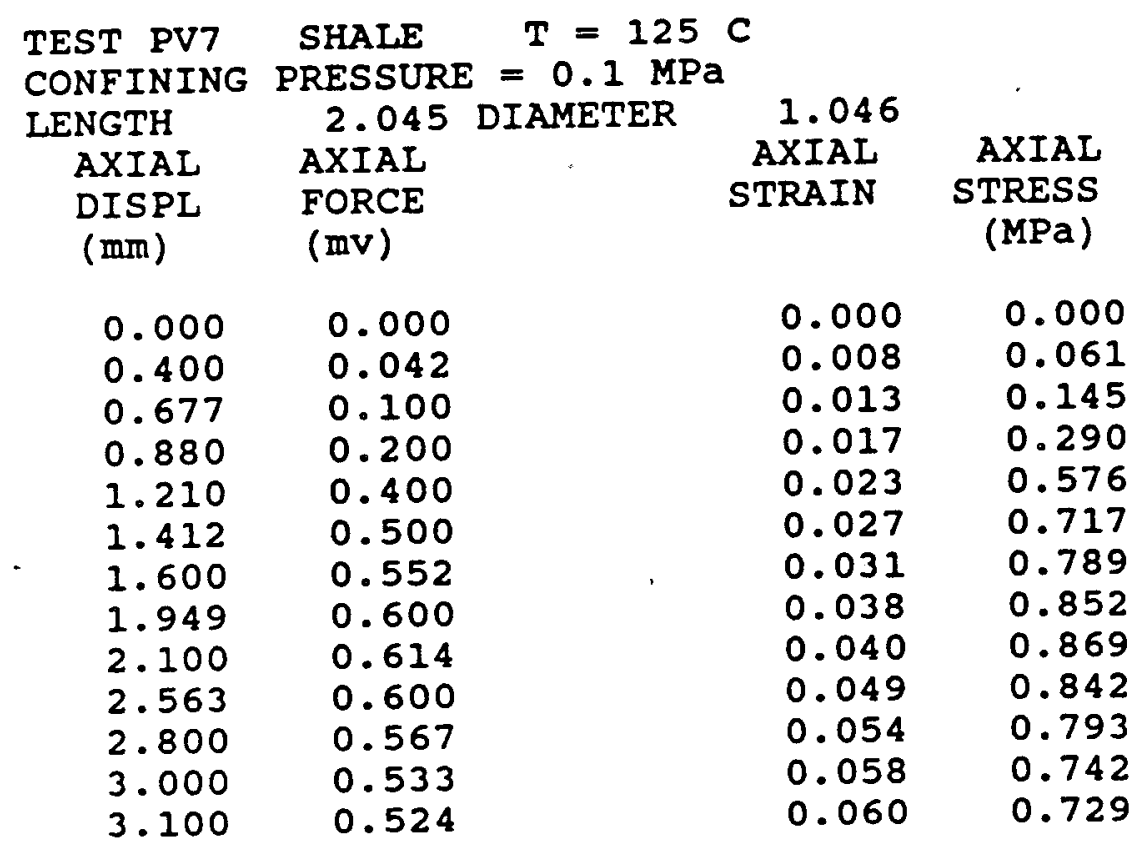


Figure $\mathrm{C}-9$

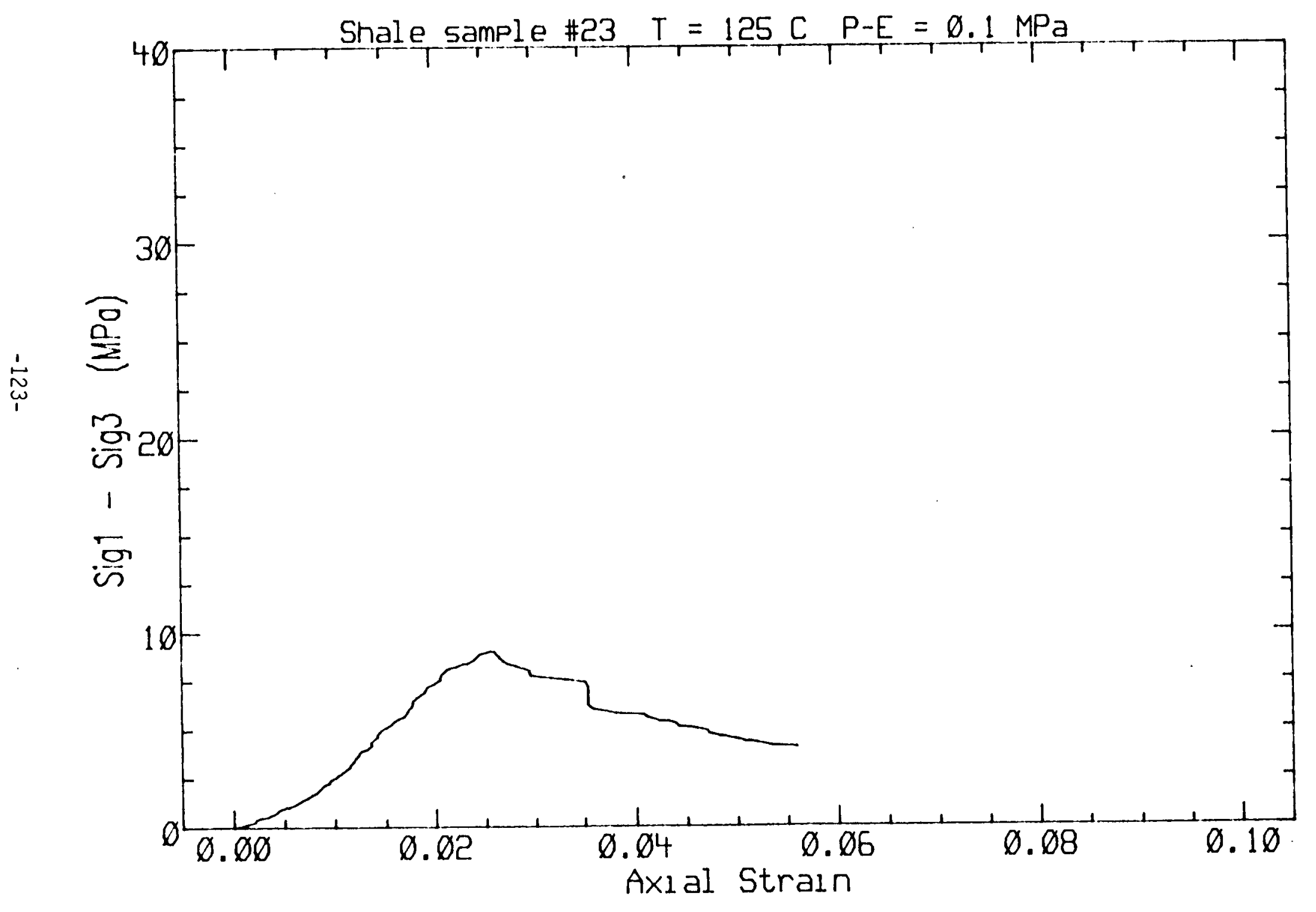




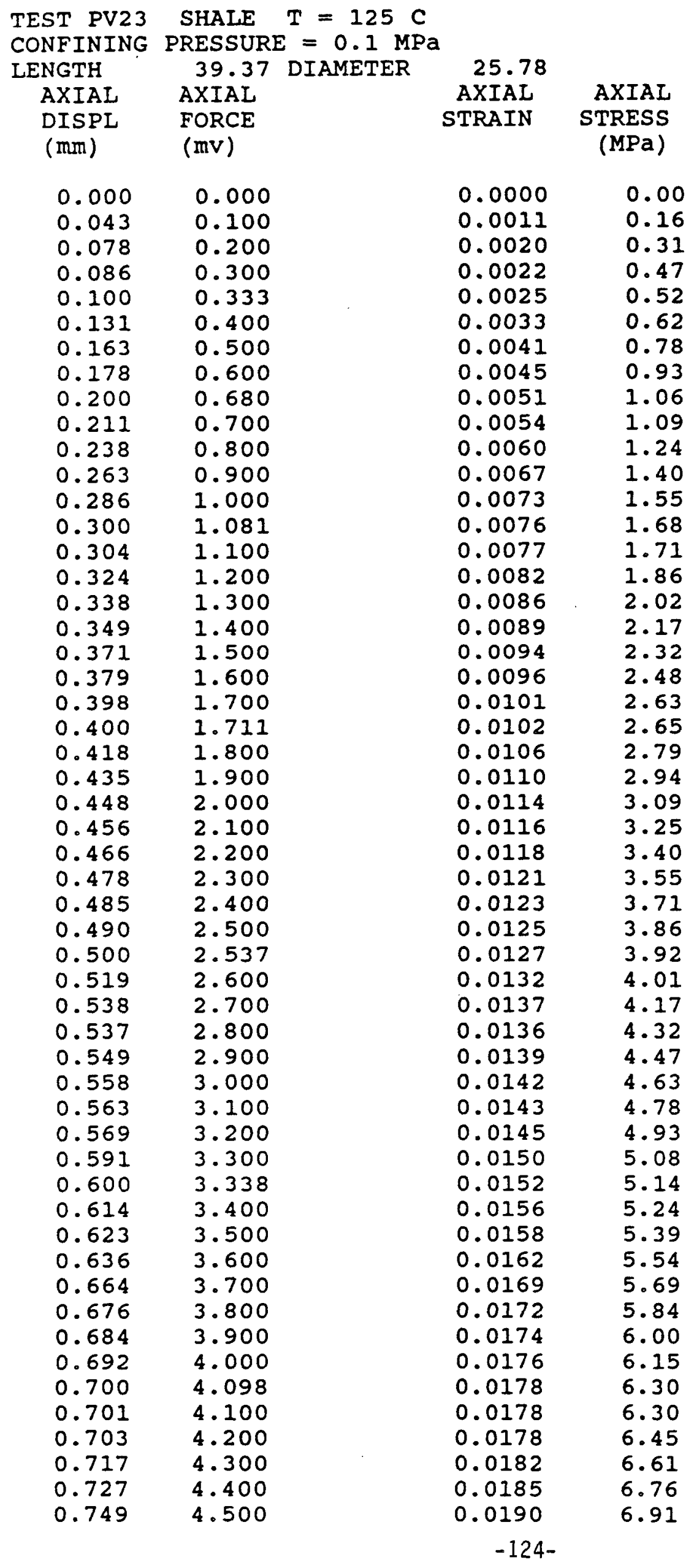




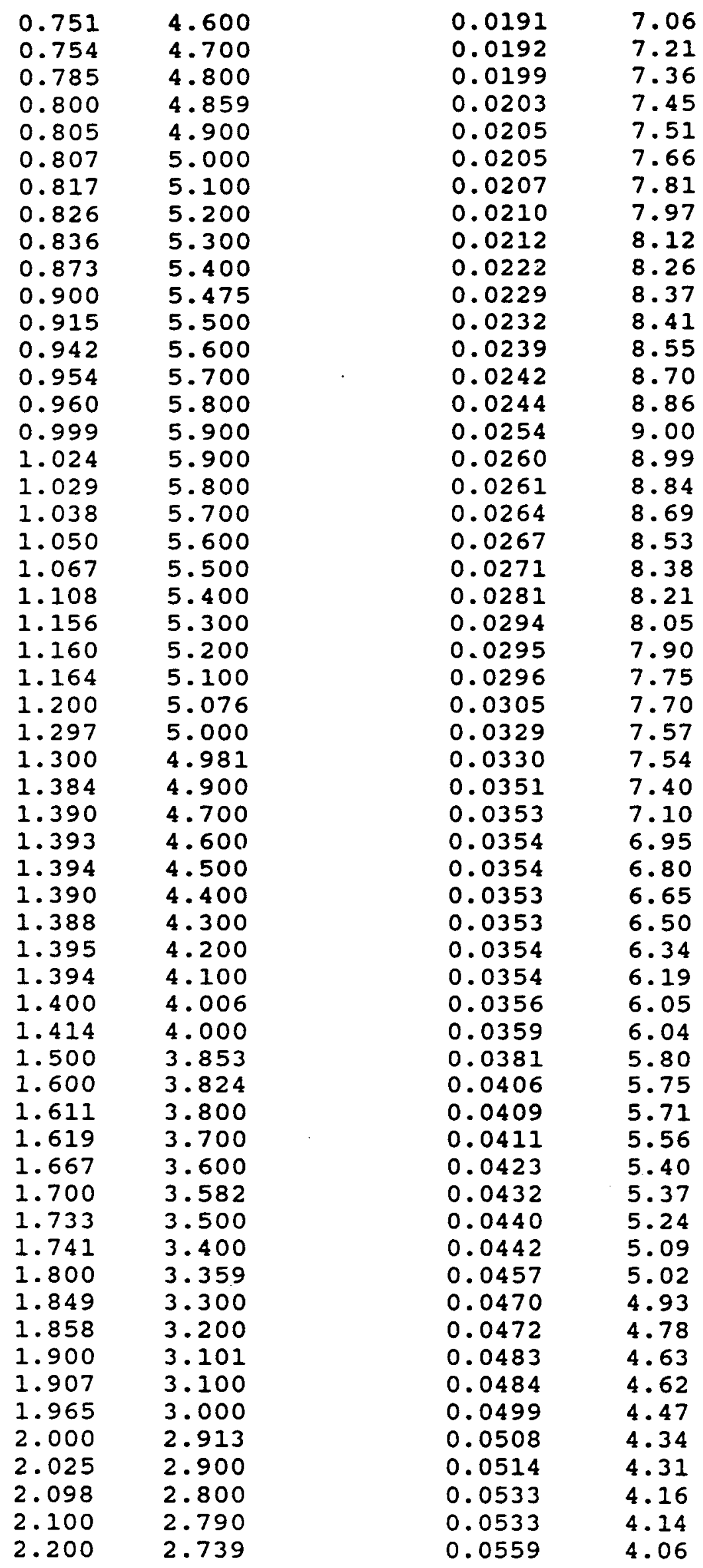


Figure $\mathrm{C}-10$

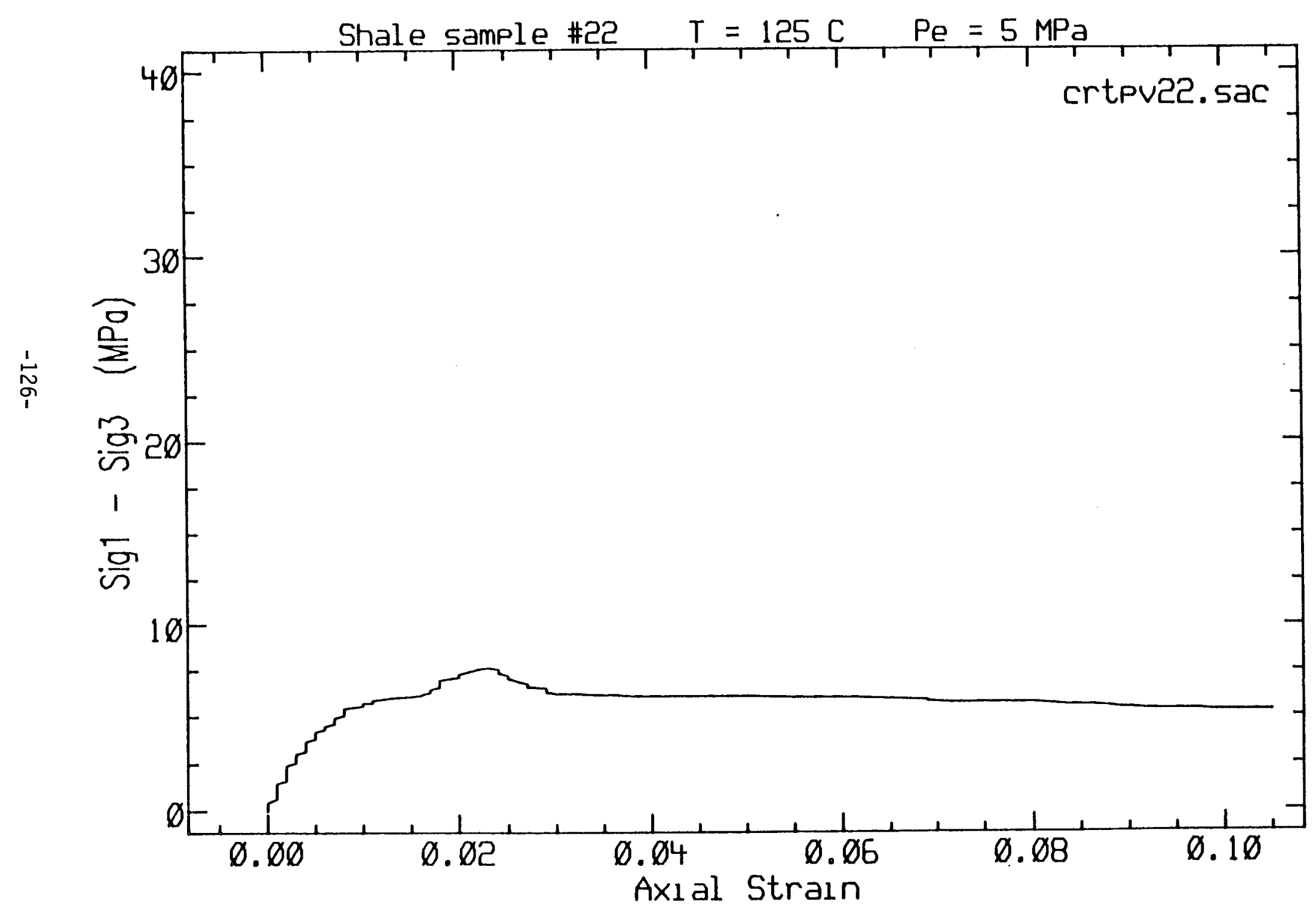




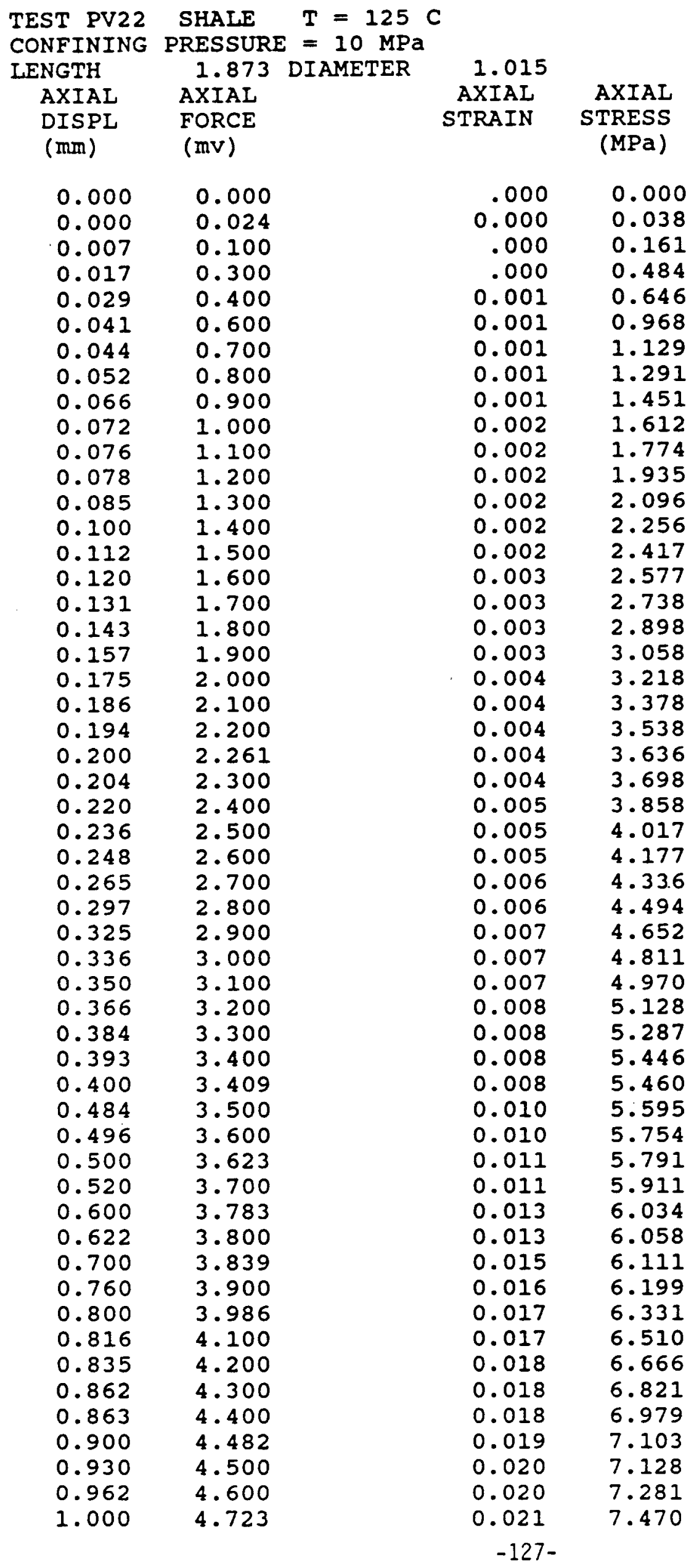




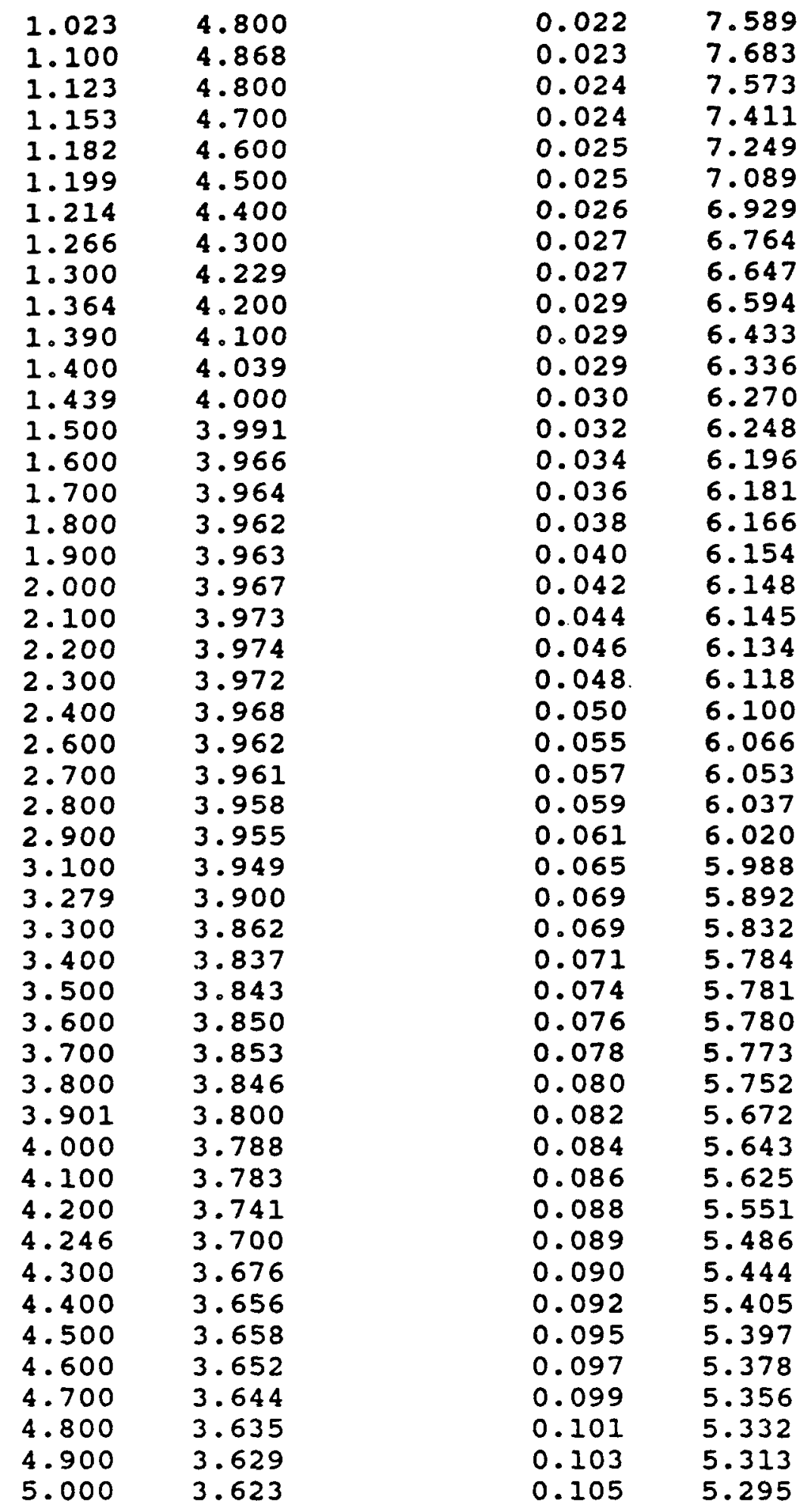


Figure C-11

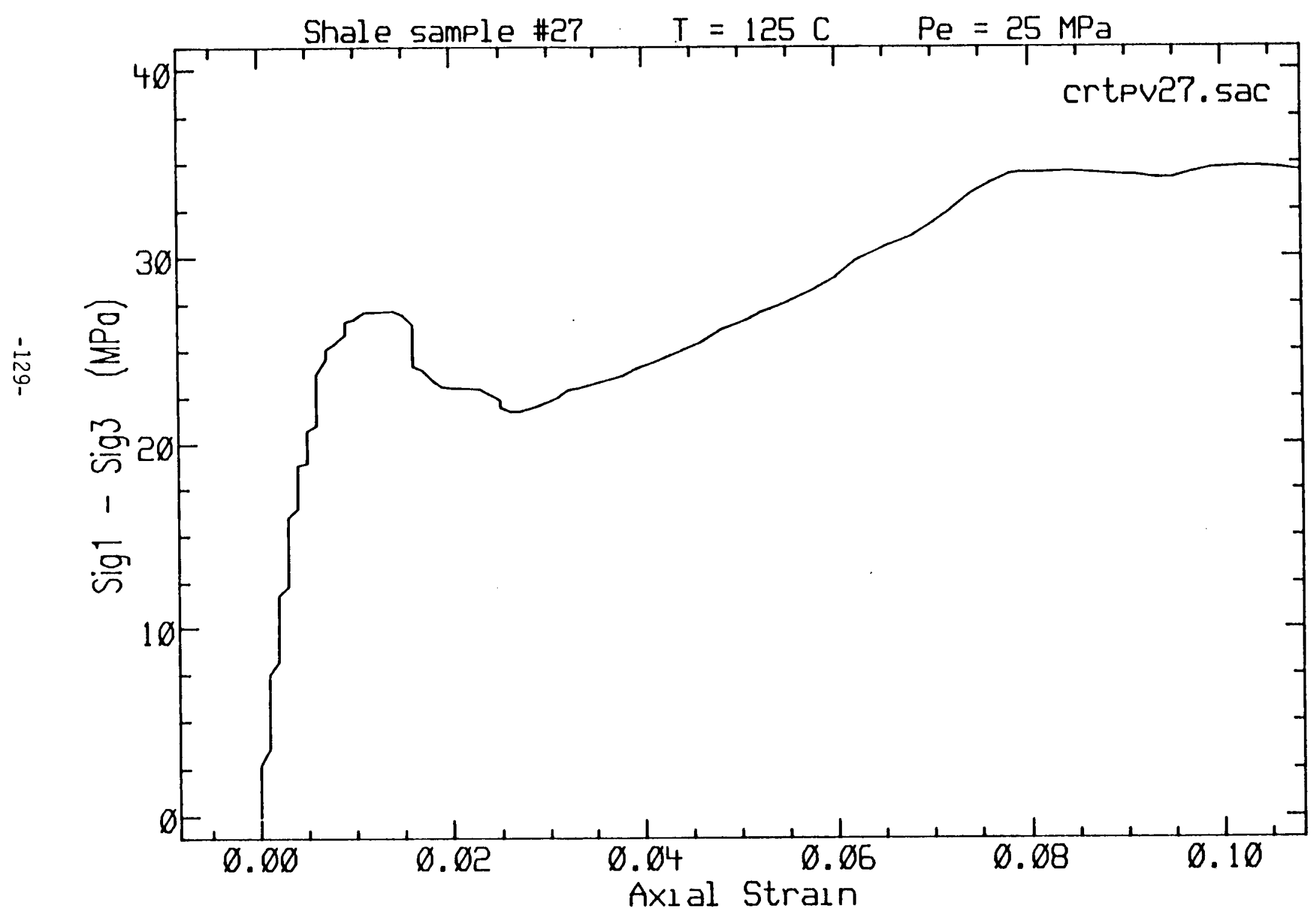




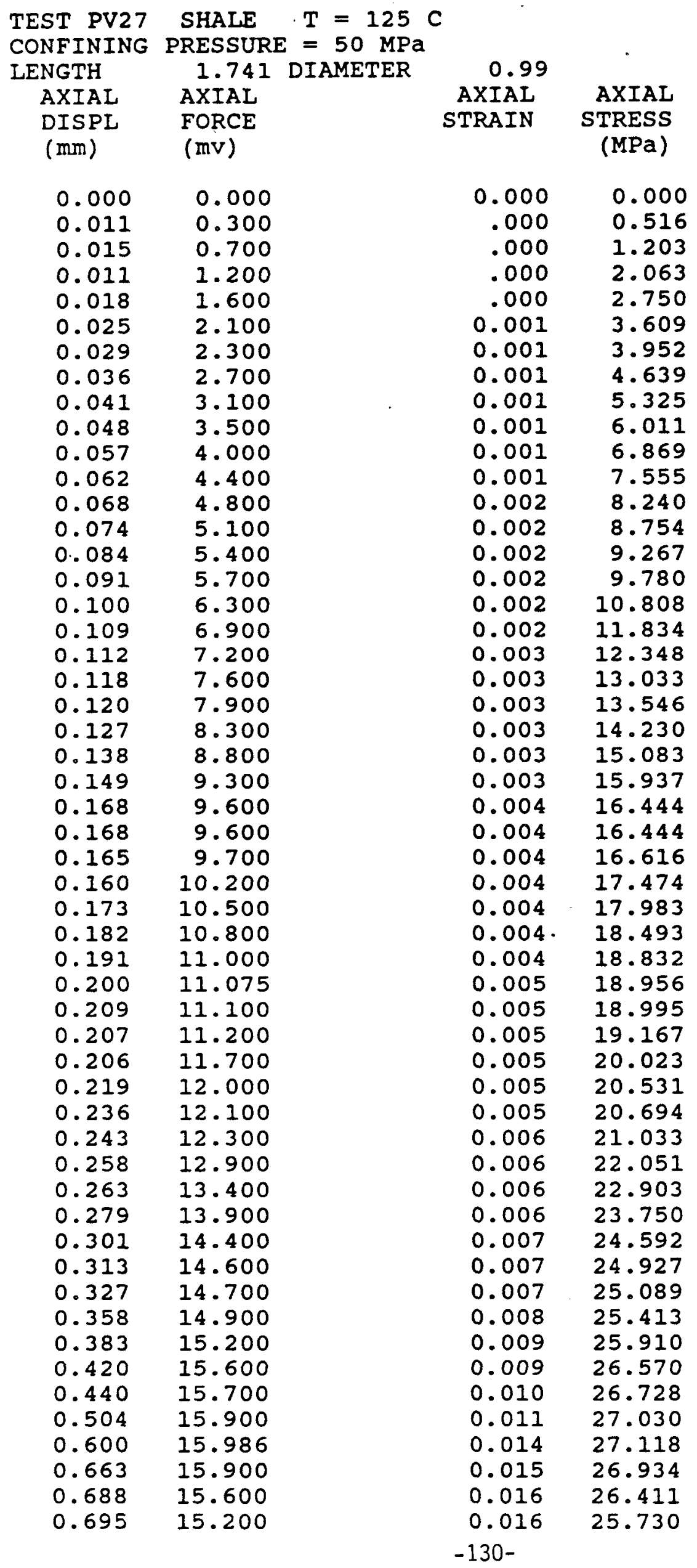




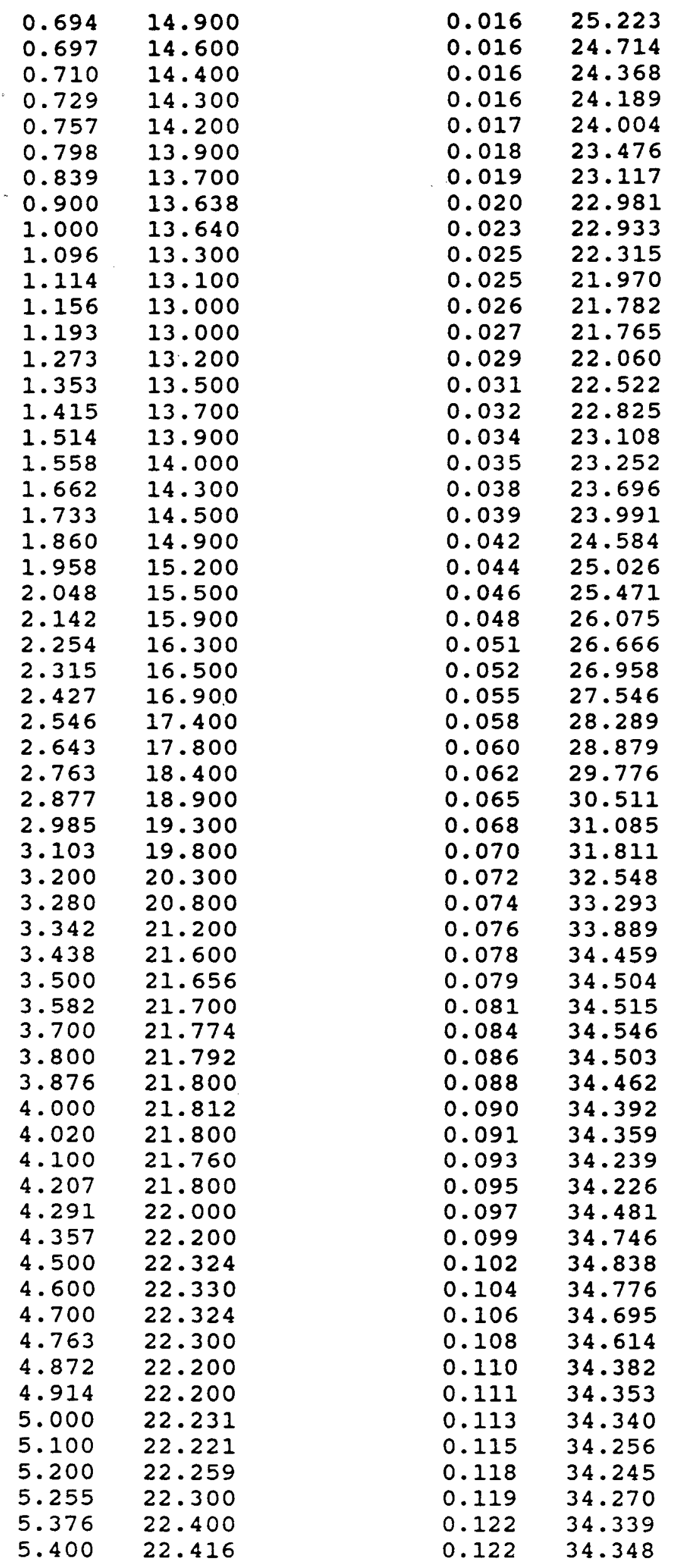




$\begin{array}{llll}5.500 & 22.464 & 0.124 & 34.351 \\ 5.600 \cdot & 22.482 & 0.127 & 34.309 \\ 5.700 & 22.458 & 0.129 & 34.205 \\ 5.800 & 22.425 & 0.131 & 34.086 \\ 5.852 & 22.400 & 0.132 & 34.013 \\ 6.040 & 22.300 & 0.137 & 33.734 \\ 6.100 & 22.289 & 0.138 & 33.677 \\ 6.200 & 22.300 & 0.140 & 33.627\end{array}$


Figure $\mathrm{C}-12$

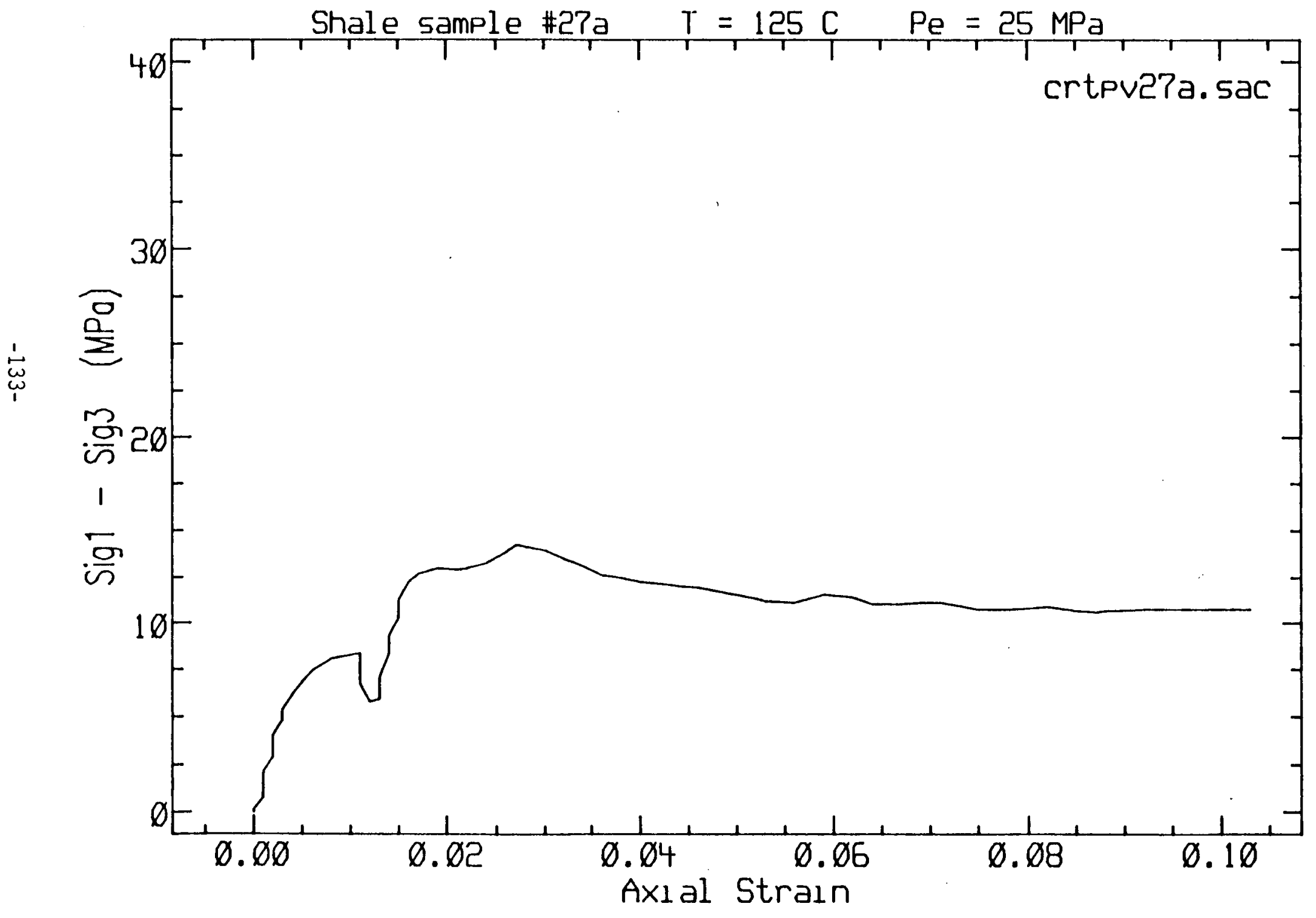




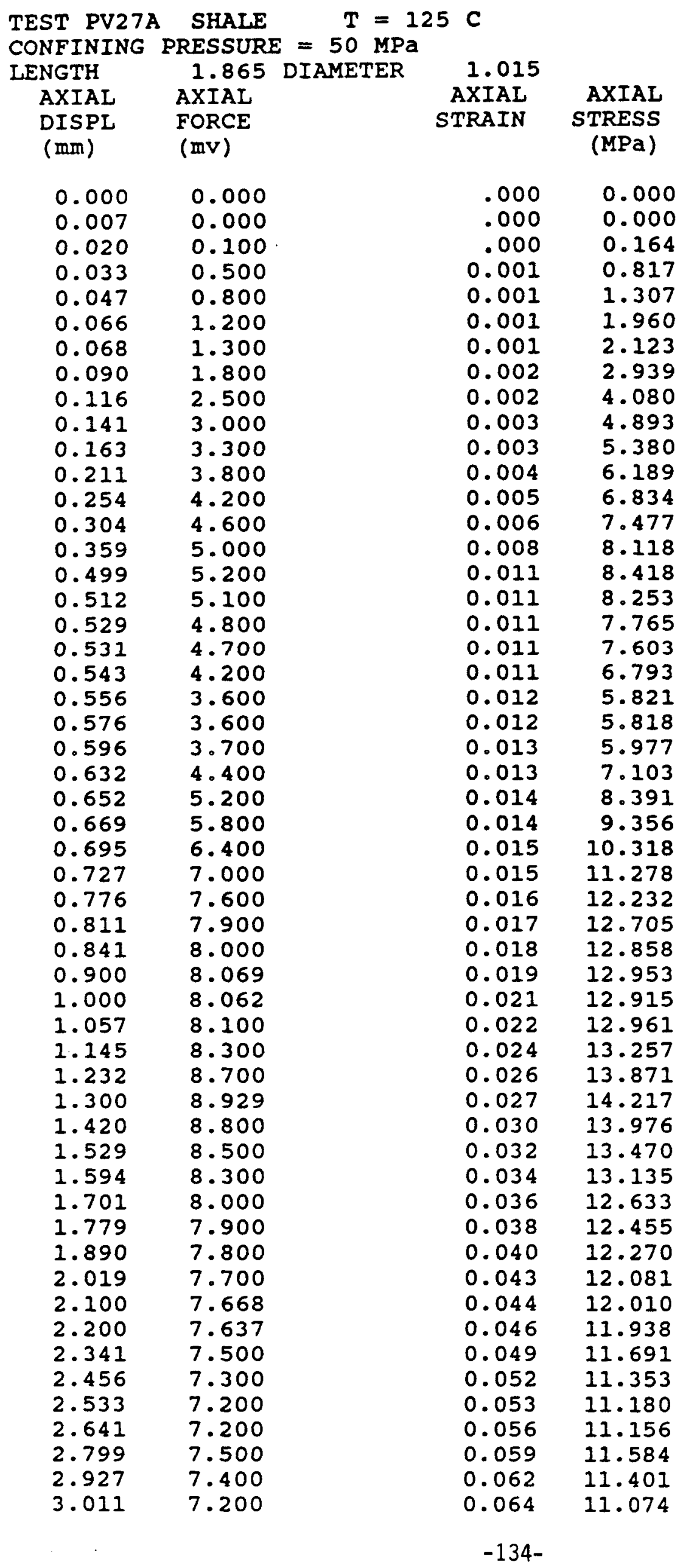




$\begin{array}{llll}3.166 & 7.200 & 0.067 & 11.040 \\ 3.273 & 7.300 & 0.069 & 11.170 \\ 3.387 & 7.300 & 0.071 & 11.145 \\ 3.557 & 7.100 & 0.075 & 10.803 \\ 3.600 & 7.085 & 0.076 & 10.771 \\ 3.694 & 7.100 & 0.078 & 10.774 \\ 3.868 & 7.200 & 0.082 & 10.889 \\ 4.020 & 7.100 & 0.085 & 10.706 \\ 4.100 & 7.073 & 0.087 & 10.649 \\ 4.156 & 7.100 & 0.088 & 10.677 \\ 4.200 & 7.120 & 0.089 & 10.698 \\ 4.372 & 7.200 & 0.092 & 10.783 \\ 4.413 & 7.200 & 0.093 & 10.774 \\ 4.569 & 7.200 & 0.096 & 10.742 \\ 4.700 & 7.231 & 0.099 & 10.761 \\ 4.800 & 7.249 & 0.101 & 10.767 \\ 4.900 & 7.254 & 0.103 & 10.754\end{array}$


Figure $\mathrm{C}-13$

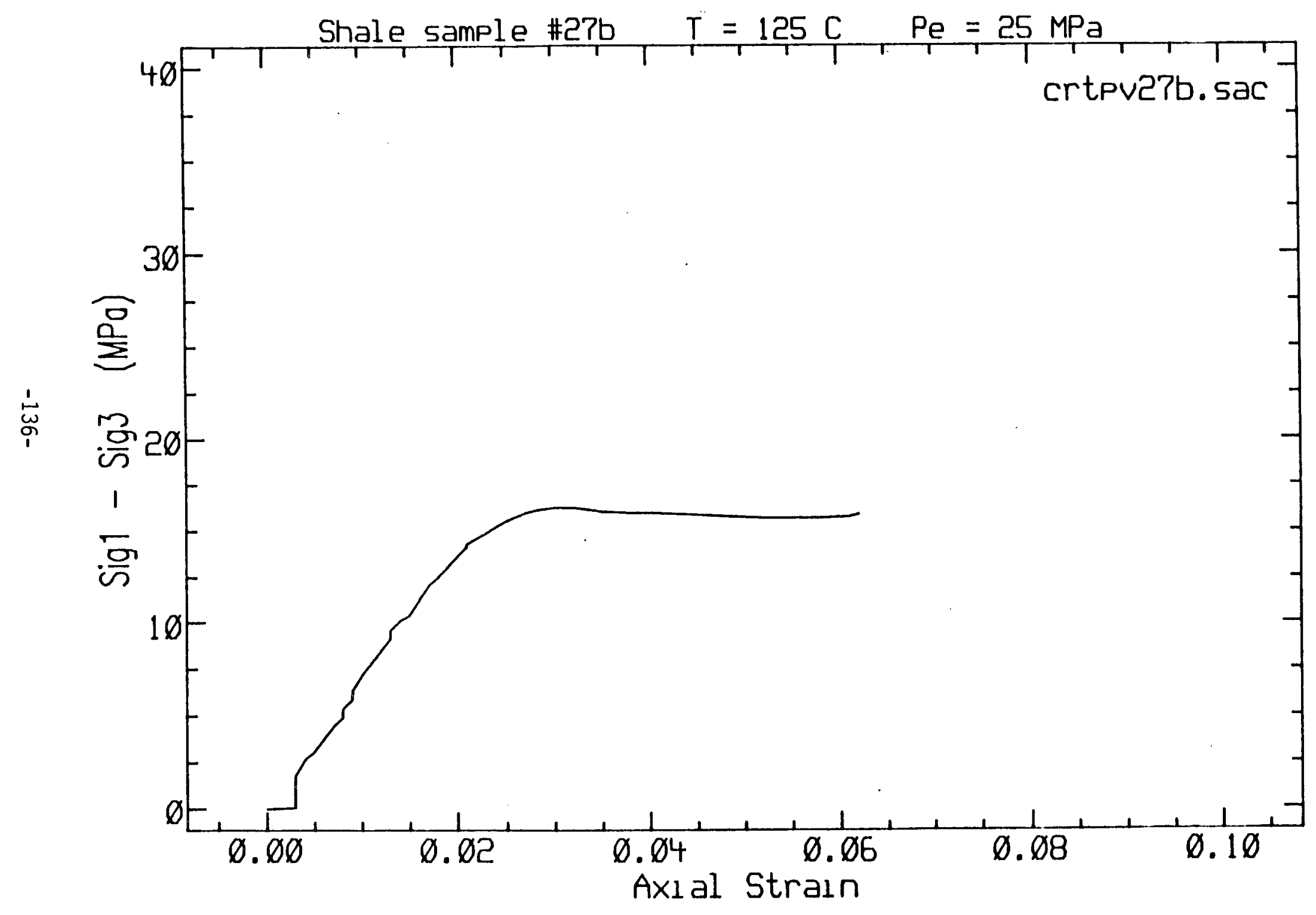


TEST PV27B SHALE $T=125 \mathrm{C}$ CONFINING PRESSURE $=50 \mathrm{MPA}$

LENGTH 1.362 DIAMETER

$\begin{array}{ll}\text { AXIAL } & \text { AXIAL } \\ \text { DISPL } & \text { FORCE } \\ (\mathrm{mm}) & (\mathrm{mV})\end{array}$

$\begin{array}{ll}0.000 & 0.000 \\ 0.100 & 0.063 \\ 0.102 & 0.100\end{array}$

AXIAL

AXIAL

STRAIN STRESS

(MPa)

$\begin{array}{lr}0.000 & 0.000 \\ 0.003 & 0.104 \\ 0.003 & 0.165 \\ 0.003 & 0.824 \\ 0.003 & 1.318 \\ 0.003 & 1.811 \\ 0.004 & 2.632 \\ 0.005 & 3.123 \\ 0.006 & 3.777 \\ 0.007 & 4.430 \\ 0.008 & 4.919 \\ 0.008 & 5.408 \\ 0.009 & 5.897 \\ 0.009 & 6.222 \\ 0.009 & 6.385 \\ 0.010 & 7.196 \\ 0.011 & 7.845 \\ 0.012 & 8.492 \\ 0.013 & 9.136 \\ 0.013 & 9.618 \\ 0.014 & 10.099 \\ 0.015 & 10.419 \\ 0.016 & 11.221 \\ 0.017 & 12.020 \\ 0.018 & 12.498 \\ 0.019 & 12.974 \\ 0.020 & 13.609 \\ 0.021 & 14.082 \\ 0.021 & 14.238 \\ 0.023 & 14.863 \\ 0.024 & 15.172 \\ 0.025 & 15.477 \\ 0.027 & 15.929 \\ 0.028 & 16.074 \\ 0.030 & 16.199 \\ 0.032 & 16.209 \\ 0.033 & 16.160 \\ 0.035 & 16.000 \\ 0.038 & 15.958 \\ 0.040 & 15.908 \\ 0.043 & 15.859 \\ 0.046 & 15.798 \\ 0.046 & 15.782 \\ 0.049 & 15.701 \\ 0.052 & 15.674 \\ 0.055 & 15.623 \\ 0.057 & 15.628 \\ 0.058 & 15.633 \\ 0.061 & 15.727 \\ 0.062 & 15.866 \\ 0.019 & \end{array}$

0.104

0.500

0.117

0.800

0.154

1.100

0.180

1.600

1.900

2.300

0.241

2.700

0.262

3.000

0.281

3.300

3.600

0.308

3.800

0.313

3.900

0.348

4.400

0.375

4.800

0.402

5.200

0.438

5.600

0.464

5.900

0.491

6.200

0.511

6.400

6.900

0.590

7.400

0.617

7.700

0.645

8.000

0.682

8.400

0.714

8.700

0.728

8.800

0.782

9.200

0.815

9.400

0.854

9.600

0.926

9.900

0.961

10.000

1.038

10.100

1.100

10.124

1.126

10.100

1.200

10.021

1. 300

10.022

1.400

10.019

10.016

1.582

10.000

9.995

9.971

9.981

9.976

1.900

10.000

1. 276

10.010

2. 108

10.100

2.146

10.200

0.062

15.866 
Figure C-14

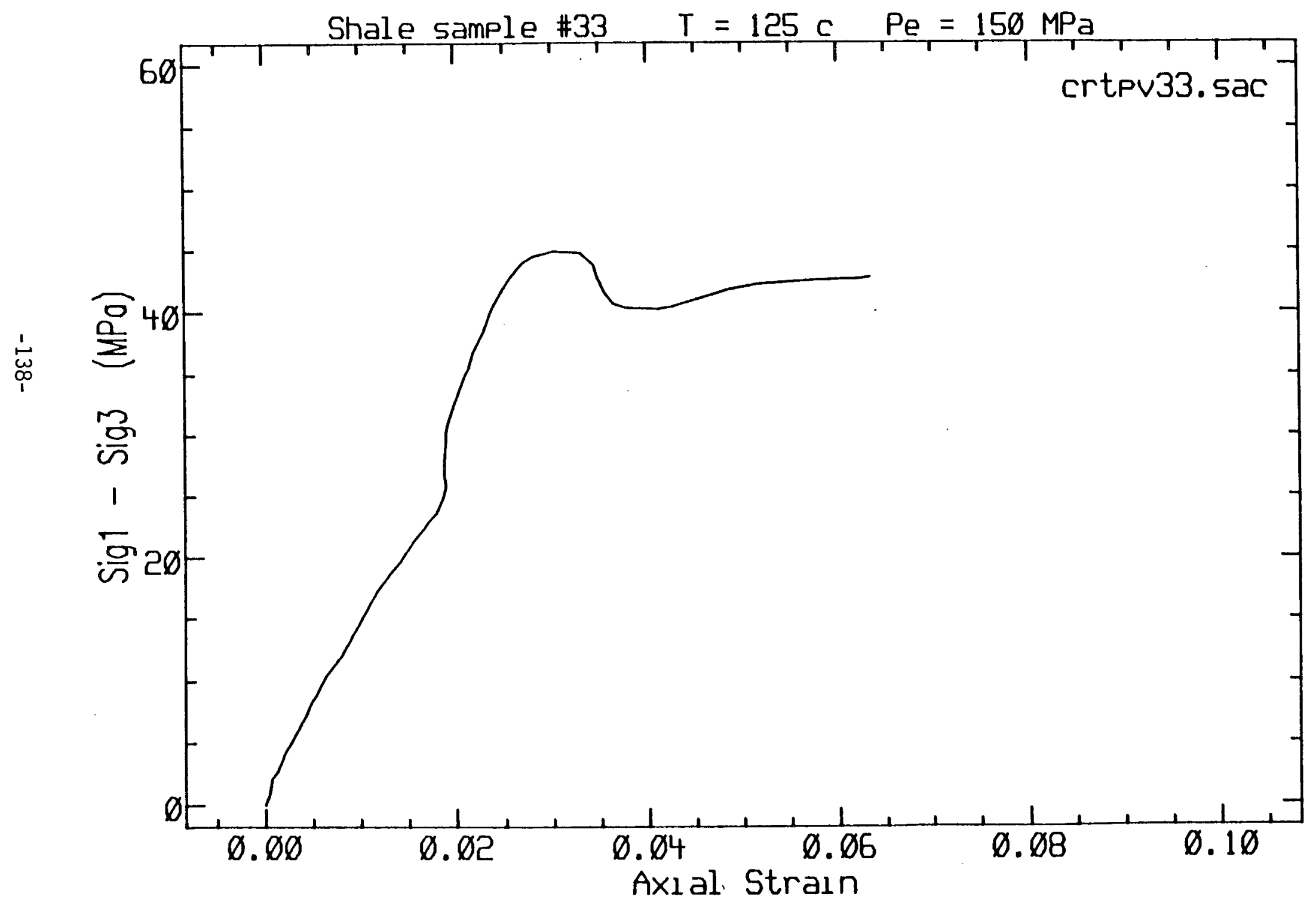




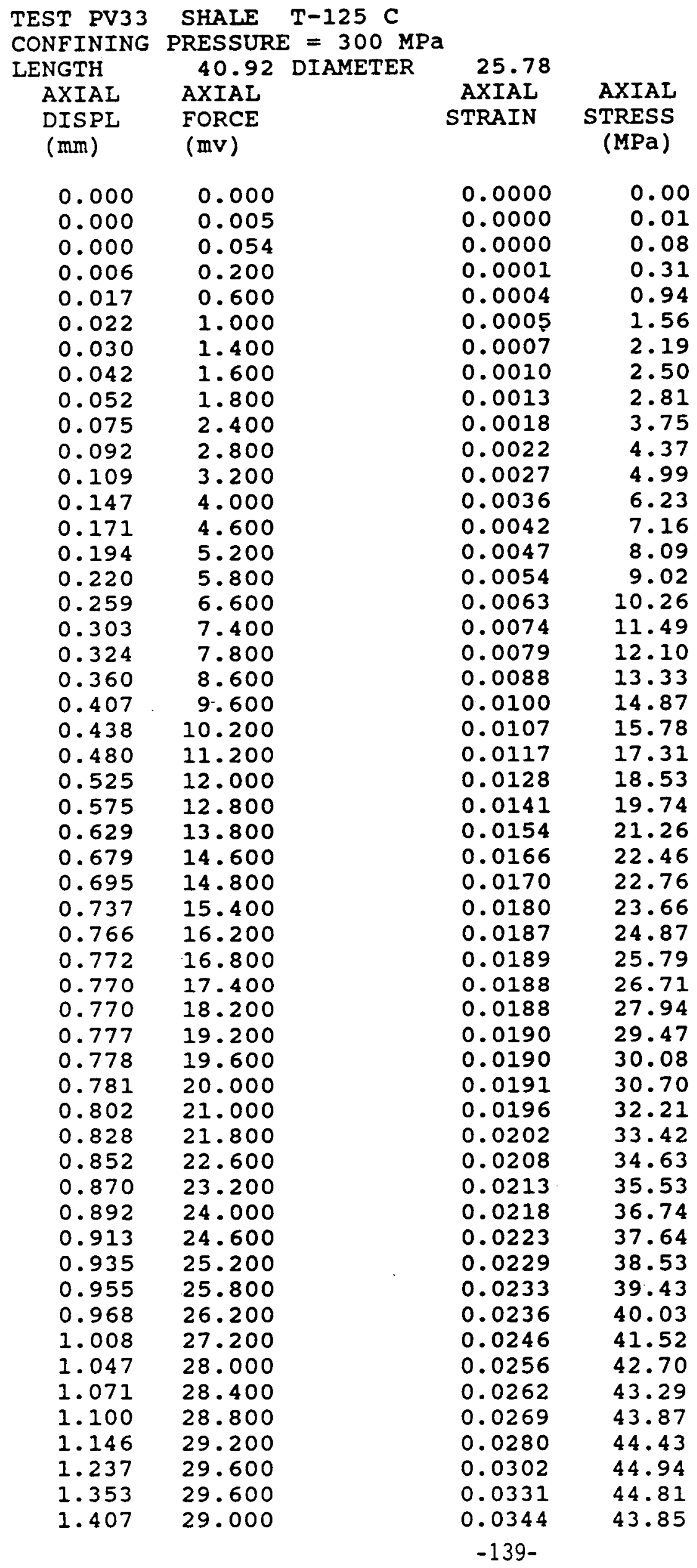




$\begin{array}{llll}1.420 & 28.400 & 0.0347 & 42.93 \\ 1.451 & 27.600 & 0.0355 & 41.69 \\ 1.493 & 27.000 & 0.0365 & 40.74 \\ 1.542 & 26.800 & 0.0377 & 40.39 \\ 1.684 & 26.800 & 0.0412 & 40.26 \\ 1.747 & 27.000 & 0.0427 & 40.50 \\ 1.844 & 27.400 & 0.0451 & 41.01 \\ 1.987 & 28.000 & 0.0486 & 41.76 \\ 2.114 & 28.400 & 0.0517 & 42.24 \\ 2.374 & 28.800 & 0.0580 & 42.57 \\ 2.400 & 28.831 & 0.0587 & 42.59 \\ 2.552 & 29.000 & 0.0624 & 42.69 \\ 2.627 & 29.200 & 0.0642 & 42.91\end{array}$


Figure $\mathrm{C}-15$

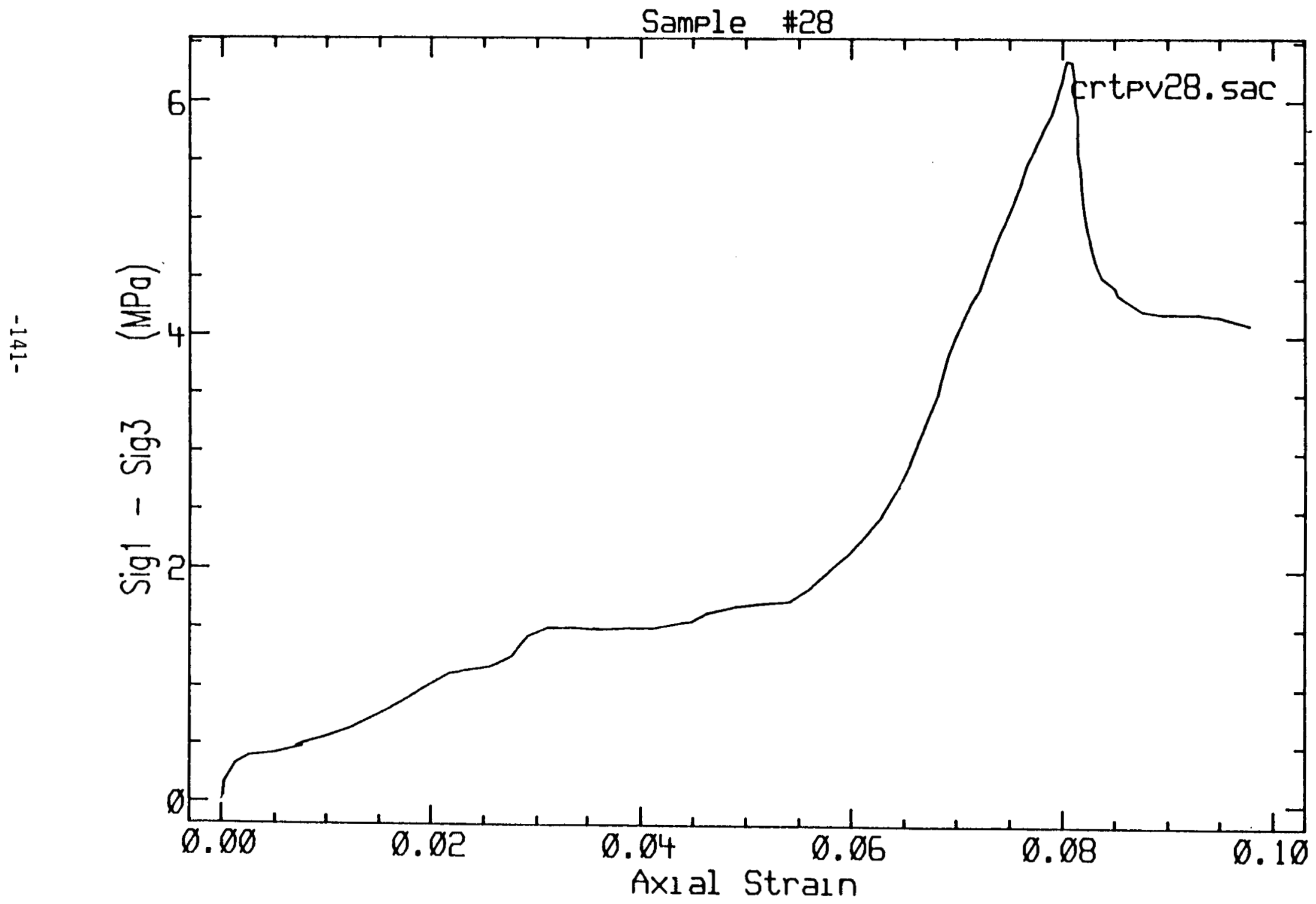




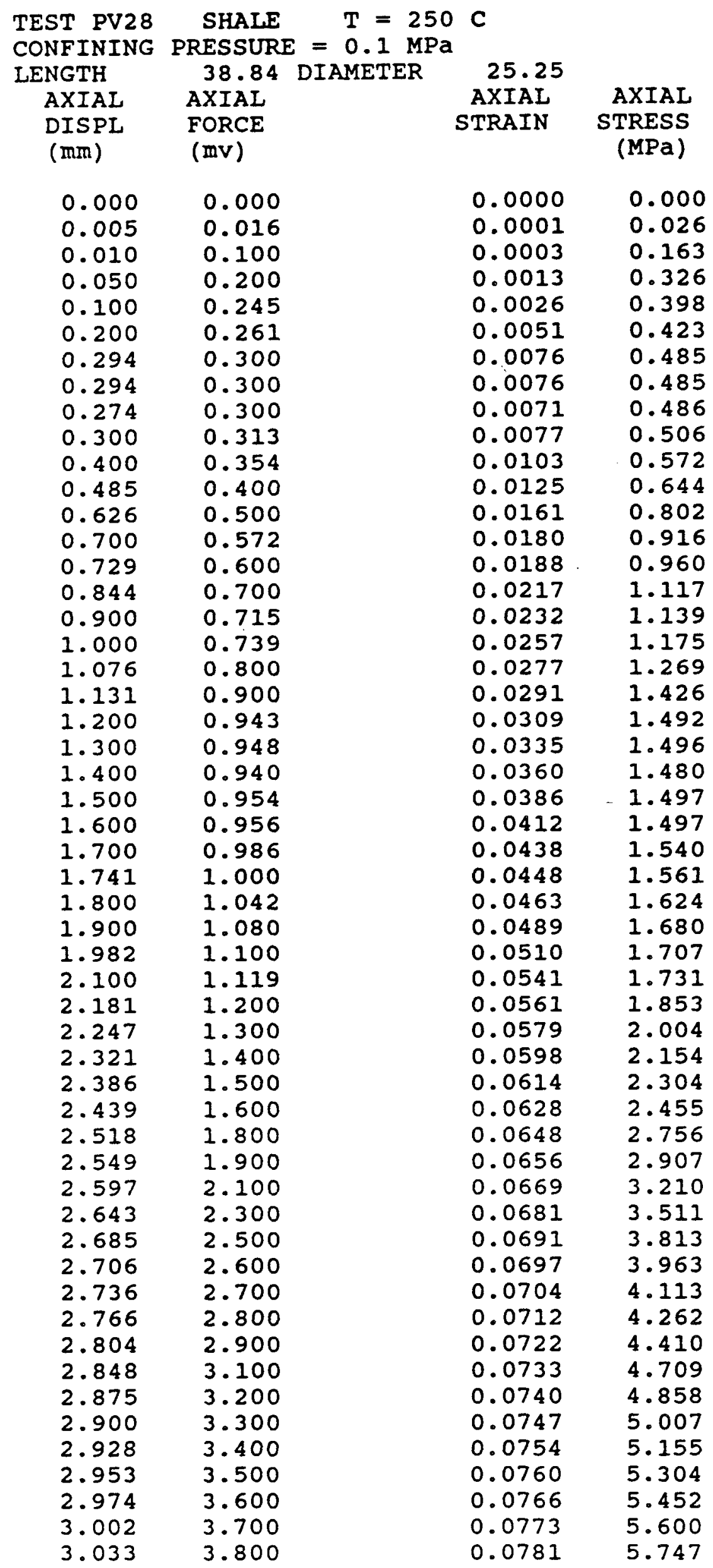




$\begin{array}{llll}3.067 & 3.900 & 0.0790 & 5.894 \\ 3.089 & 4.000 & 0.0795 & 6.042 \\ 3.106 & 4.100 & 0.0800 & 6.190 \\ 3.126 & 4.200 & 0.0805 & 6.338 \\ 3.145 & 4.200 & 0.0810 & 6.335 \\ 3.153 & 4.100 & 0.0812 & 6.183 \\ 3.155 & 4.000 & 0.0812 & 6.032 \\ 3.164 & 3.900 & 0.0815 & 5.880 \\ 3.167 & 3.800 & 0.0815 & 5.729 \\ 3.167 & 3.700 & 0.0815 & 5.578 \\ 3.174 & 3.600 & 0.0817 & 5.427 \\ 3.181 & 3.500 & 0.0819 & 5.275 \\ 3.185 & 3.400 & 0.0820 & 5.124 \\ 3.195 & 3.300 & 0.0823 & 4.972 \\ 3.212 & 3.200 & 0.0827 & 4.819 \\ 3.225 & 3.100 & 0.0830 & 4.667 \\ 3.249 & 3.000 & 0.0837 & 4.514 \\ 3.300 & 2.940 & 0.0850 & 4.418 \\ 3.308 & 2.900 & 0.0852 & 4.357 \\ 3.400 & 2.816 & 0.0875 & 4.221 \\ 3.472 & 2.800 & 0.0894 & 4.191 \\ 3.485 & 2.800 & 0.0897 & 4.190 \\ 3.500 & 2.801 & 0.0901 & 4.190 \\ 3.600 & 2.810 & 0.0927 & 4.193 \\ 3.686 & 2.800 & 0.0949 & 4.170 \\ 3.700 & 2.795 & 0.0953 & 4.161 \\ 3.800 & 2.758 & 0.0978 & 4.097\end{array}$


Figure $\mathrm{C}-16$

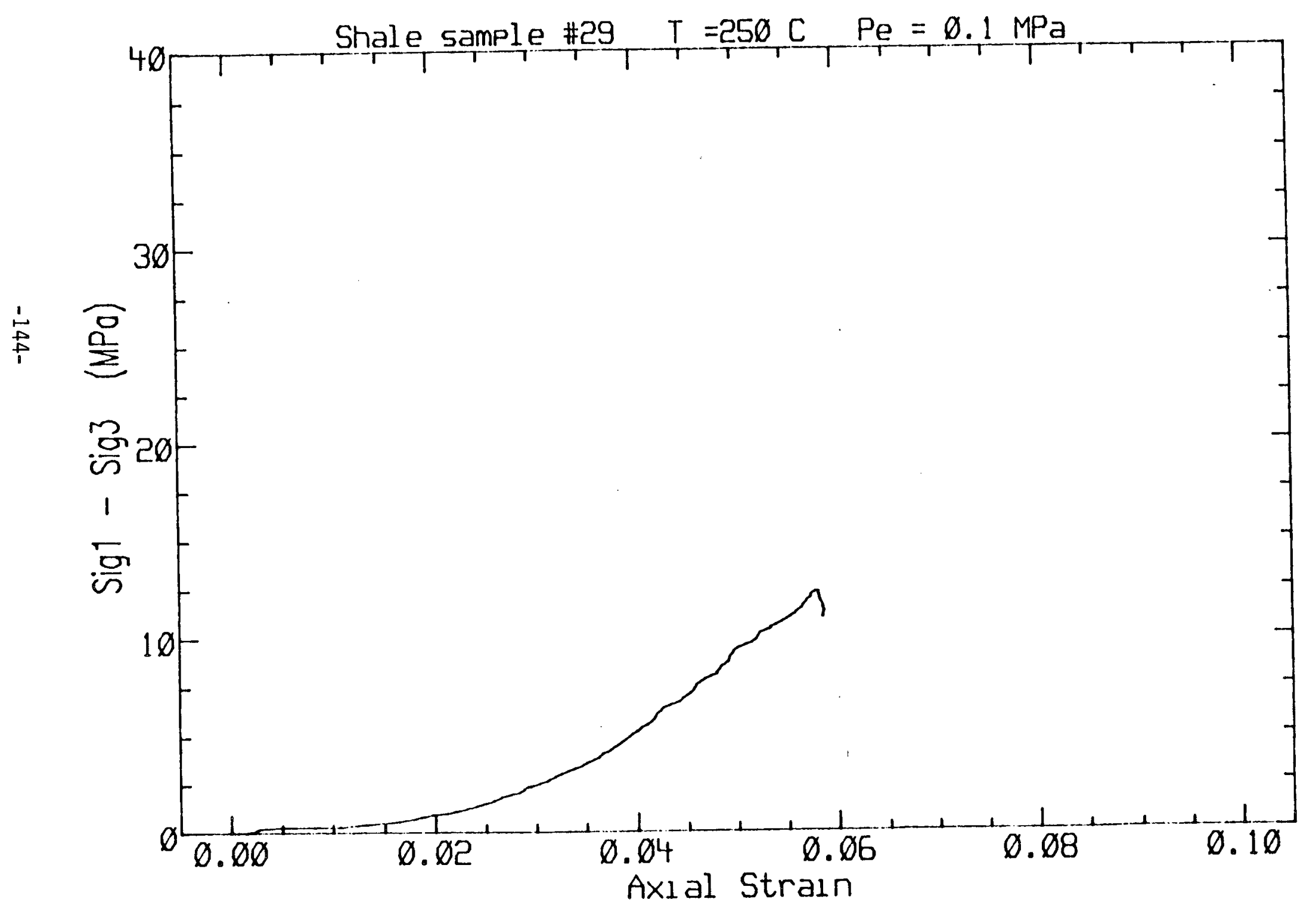




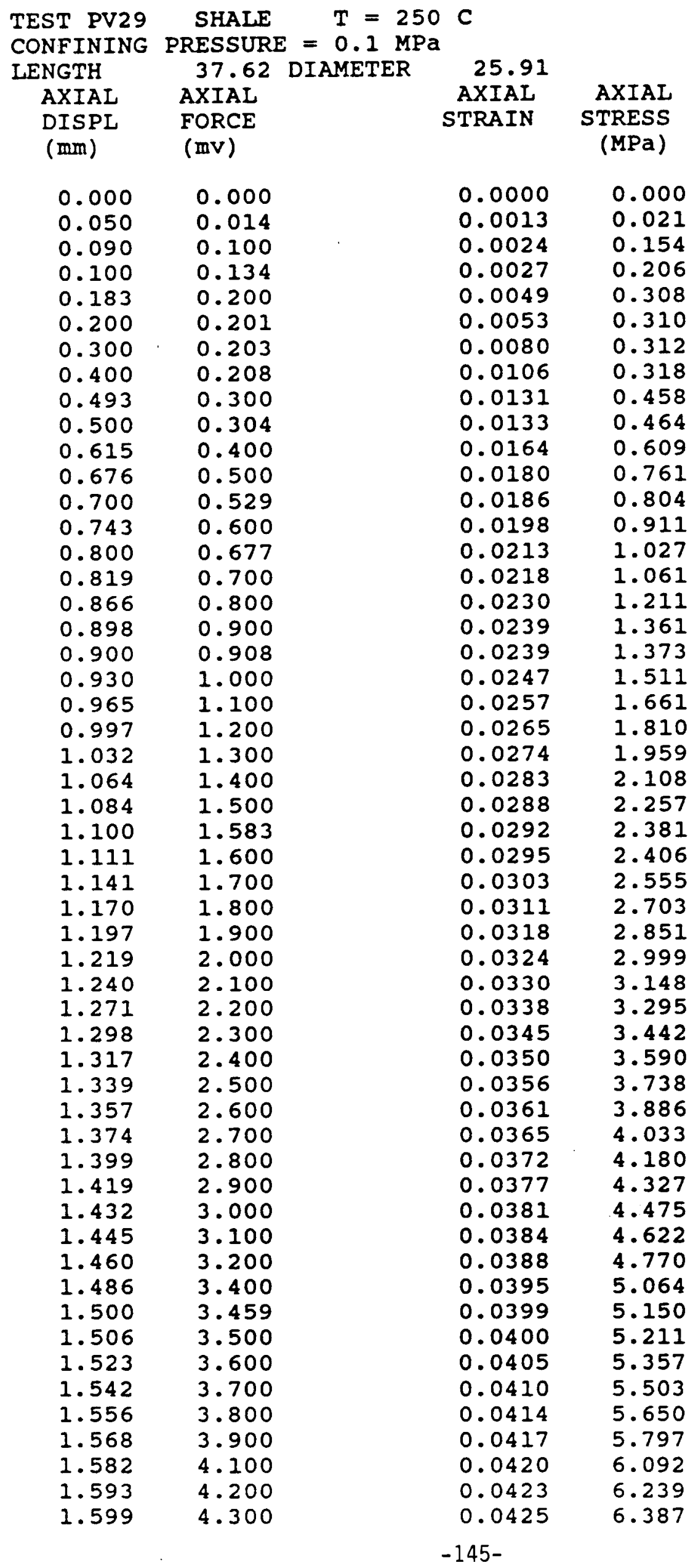




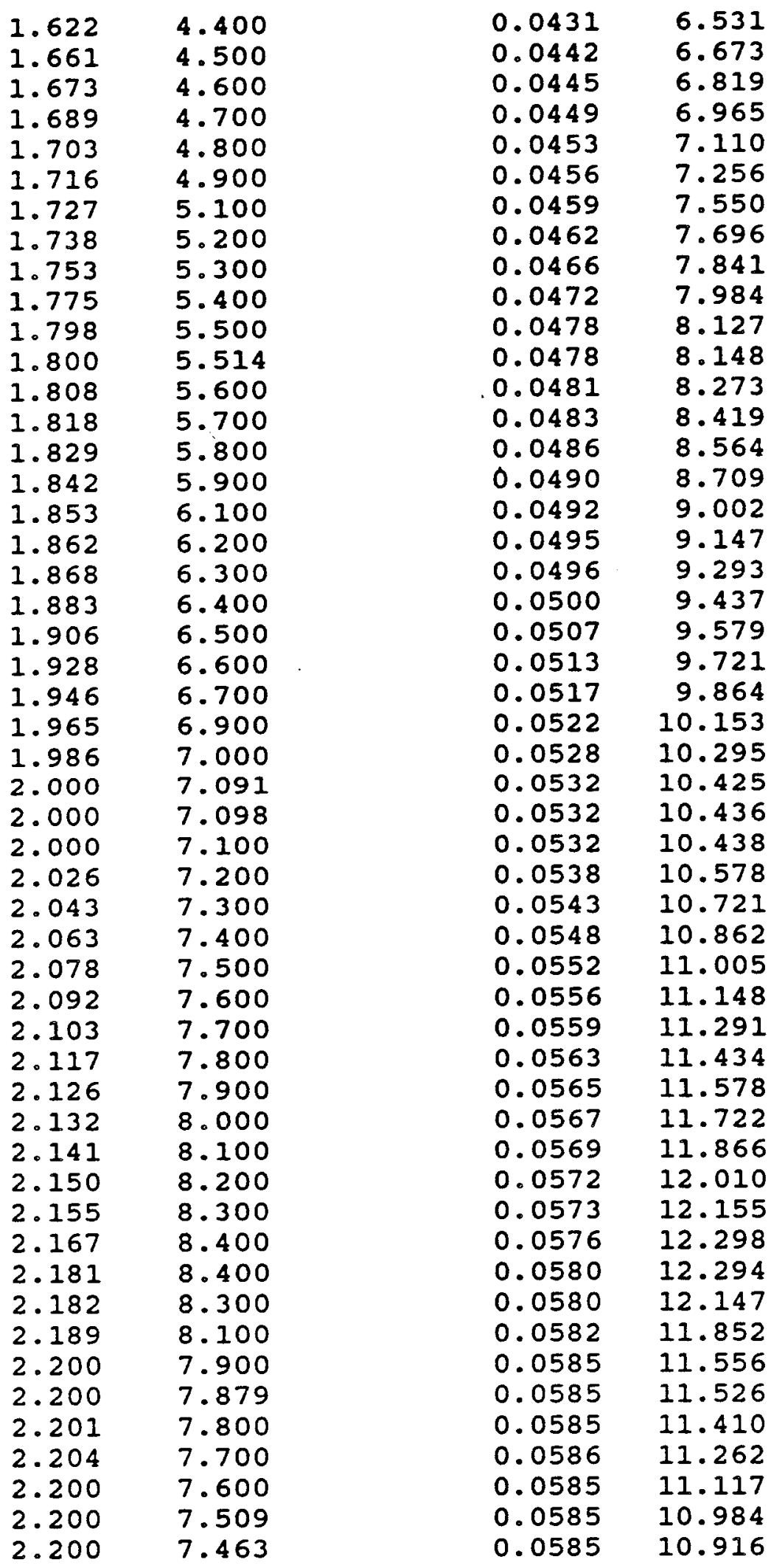


Figure $\mathrm{C}-17$

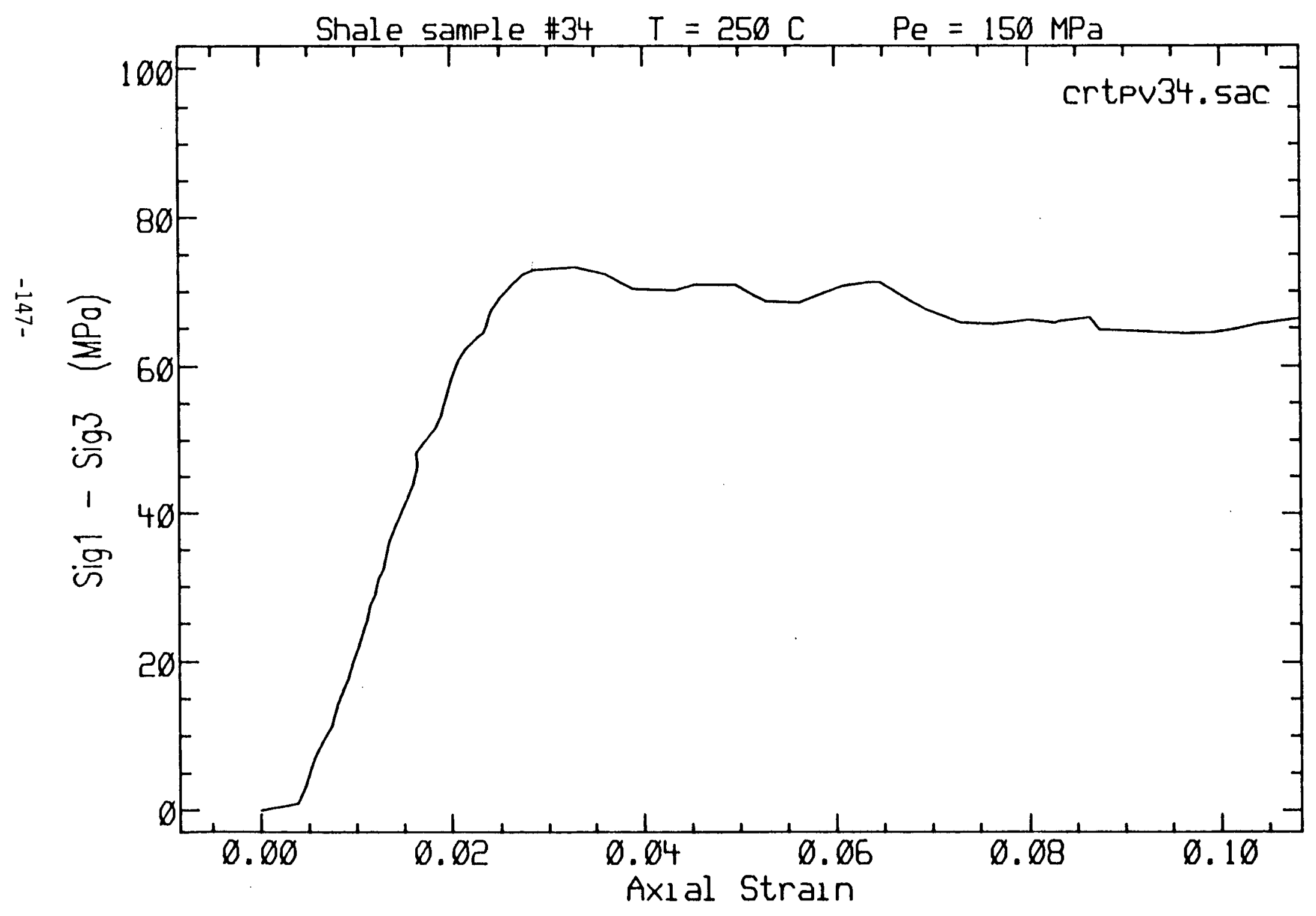




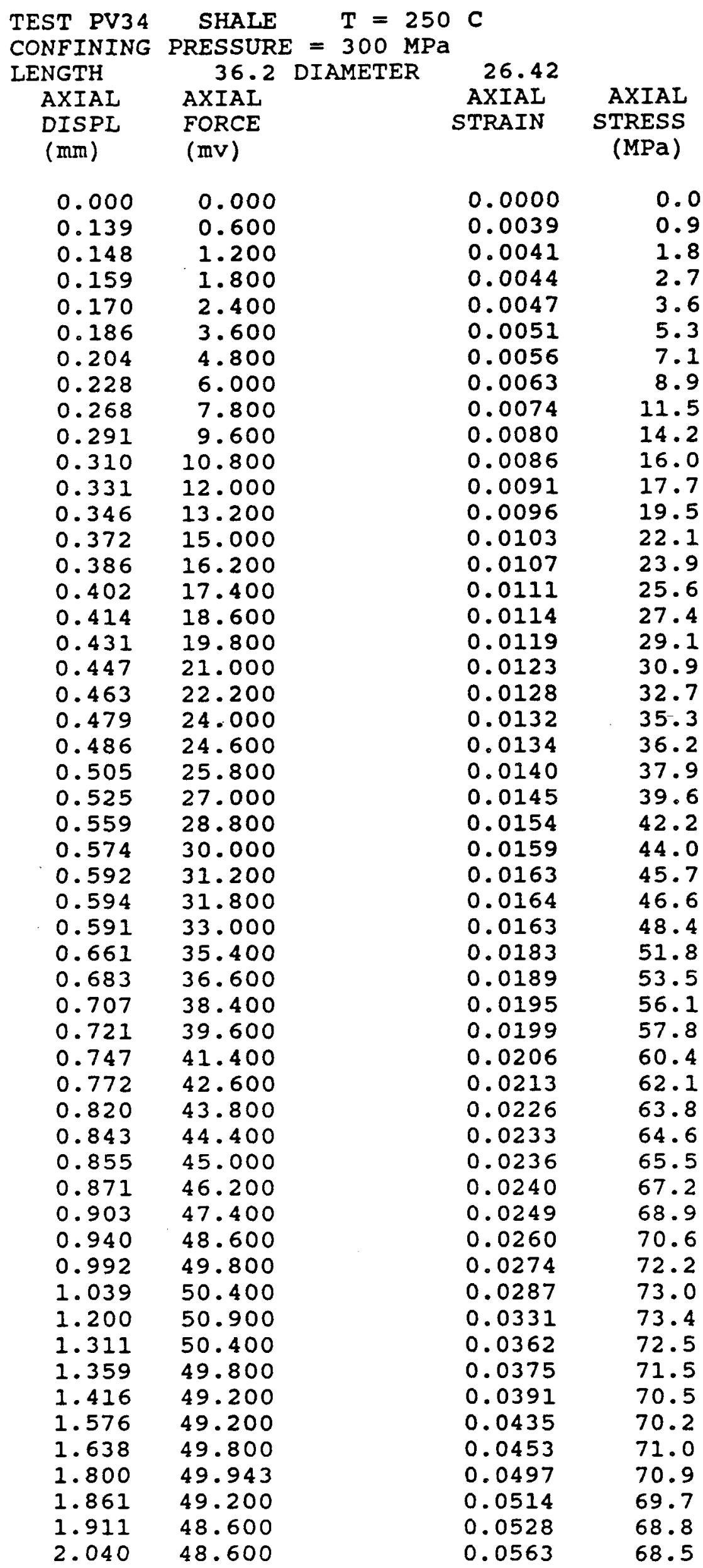




$\begin{array}{llll}2.087 & 49.200 & 0.0577 & 69.3 \\ 2.199 & 50.400 & 0.0607 & 70.8 \\ 2.296 & 51.000 & 0.0634 & 71.4 \\ 2.344 & 51.000 & 0.0647 & 71.4 \\ 2.423 & 49.800 & 0.0669 & 69.5 \\ 2.512 & 48.600 & 0.0694 & 67.7 \\ 2.645 & 47.400 & 0.0731 & 65.8 \\ 2.769 & 47.400 & 0.0765 & 65.6 \\ 2.891 & 48.000 & 0.0799 & 66.2 \\ 2.911 & 48.000 & 0.0804 & 66.2 \\ 3.000 & 47.880 & 0.0829 & 65.9 \\ 3.013 & 48.000 & 0.0832 & 66.0 \\ 3.131 & 48.600 & 0.0865 & 66.6 \\ 3.166 & 47.400 & 0.0875 & 64.9 \\ 3.505 & 47.400 & 0.0968 & 64.4 \\ 3.600 & 47.654 & 0.0994 & 64.6 \\ 3.674 & 48.000 & 0.1015 & 64.9 \\ 3.764 & 48.600 & 0.1040 & 65.6 \\ 3.878 & 49.200 & 0.1071 & 66.2 \\ 4.012 & 49.800 & 0.1108 & 66.8 \\ 4.035 & 49.800 & 0.1115 & 66.7 \\ 4.103 & 49.200 & 0.1133 & 65.8 \\ 4.130 & 48.000 & 0.1141 & 64.2 \\ 4.200 & 47.702 & 0.1160 & 63.7 \\ 4.256 & 48.000 & 0.1176 & 64.0 \\ 4.314 & 48.000 & 0.1192 & 63.9 \\ 4.309 & 47.400 & 0.1190 & 63.1 \\ 4.305 & 45.600 & 0.1189 & 60.7 \\ 4.317 & 43.800 & 0.1193 & 58.3 \\ 4.326 & 43.200 & 0.1195 & 57.5\end{array}$


APPENDIX D

TABULATED DATA FOR LONG-TERM CREEP/COMPACTION TESTS ON OIL-SAND AND SHALE SAMPLES 
Table D-1. Summary of conditions of the long-term creep tests.

\begin{tabular}{|c|c|c|c|c|c|c|c|c|c|c|c|}
\hline \multirow{3}{*}{\multicolumn{2}{|c|}{$\begin{array}{l}\text { Test No. (date) } \\
\text { 1. }\left(\begin{array}{c}(4 / 30 / 86- \\
5 / 27 / 86)\end{array}\right.\end{array}$}} & \multirow{3}{*}{ Sample } & \multirow{3}{*}{$\frac{\text { Core }}{\mathrm{ND}^{*}}$} & \multirow{3}{*}{$\begin{array}{l}\text { Depth } \\
(\mathrm{ft})\end{array}$} & \multirow{3}{*}{$\begin{array}{c}\begin{array}{c}\text { Temperature } \\
\left({ }^{\circ} \mathrm{C}\right)\end{array} \\
25\end{array}$} & \multicolumn{4}{|c|}{ Pressure } & \multirow[b]{2}{*}{$\begin{array}{l}\text { Initial } \\
\text { Volume }\end{array}$} & \multirow[b]{2}{*}{ Density } \\
\hline & & & & & & \multicolumn{2}{|c|}{$\begin{array}{l}\text { Confining } \\
(\mathrm{ps} 1)(\mathrm{MPa})\end{array}$} & \multicolumn{2}{|c|}{$\begin{array}{l}\text { Effective } \\
\text { (psi) (MPa) }\end{array}$} & & \\
\hline & & & & & & $\begin{array}{r}900 \\
1300 \\
1700\end{array}$ & $\begin{array}{l}6.21 \\
8.97 \\
11.72\end{array}$ & $\begin{array}{l}420 \\
625 \\
825\end{array}$ & $\begin{array}{l}2.90 \\
4.31 \\
5.69\end{array}$ & $\begin{array}{l}101.69 \\
101.69 \\
101.69\end{array}$ & $\begin{array}{l}\text { ND } \\
\text { ND } \\
\text { ND }\end{array}$ \\
\hline \multirow[t]{3}{*}{2.} & $\begin{array}{r}(7 / 14 / 86- \\
8 / 15 / 86)\end{array}$ & 2a Shale & ND & $3309.6-\mathrm{ft}$ & 25 & $\begin{array}{r}540 \\
1200 \\
1600\end{array}$ & $\begin{array}{l}3.72 \\
8.28 \\
11.03\end{array}$ & $\begin{array}{l}200 \\
600 \\
800\end{array}$ & $\begin{array}{l}1.38 \\
4.14 \\
5.52\end{array}$ & 73.47 & 1.701 \\
\hline & & $2 b$ Shale & ND & $3206-f t$ & 25 & $\begin{array}{r}540 \\
1200 \\
1600\end{array}$ & $\begin{array}{l}3.72 \\
8.28 \\
11.03\end{array}$ & $\begin{array}{l}175 \\
615 \\
820\end{array}$ & $\begin{array}{l}1.21 \\
4.24 \\
5.44\end{array}$ & 102.73 & 1.97 \\
\hline & & 2c Shale & ND & $3280-\mathrm{ft}$ & 25 & $\begin{array}{r}540 \\
1200 \\
1600\end{array}$ & $\begin{array}{l}3.72 \\
8.28 \\
11.03\end{array}$ & $\begin{array}{l}165 \\
635 \\
836\end{array}$ & $\begin{array}{l}1.10 \\
4.21 \\
5.55\end{array}$ & 72.26 & 1.85 \\
\hline \multirow[t]{3}{*}{3.} & $\begin{array}{l}(9 / 3 / 86- \\
10 / 13 / 86)\end{array}$ & 3a Shale & 49 & $3202-\mathrm{ft}$ & 125 & $\begin{array}{r}800 \\
1200\end{array}$ & $\begin{array}{l}5.52 \\
8.28\end{array}$ & $\begin{array}{l}400 \\
540\end{array}$ & $\begin{array}{l}2.76 \\
3.72\end{array}$ & 78.1 & 2.074 \\
\hline & & 3b Shale & 70 & $3280-f t$ & 125 & $\begin{array}{r}800 \\
1200\end{array}$ & $\begin{array}{l}5.52 \\
8.28\end{array}$ & $\begin{array}{l}450 \\
645\end{array}$ & $\begin{array}{l}3.10 \\
4.45\end{array}$ & 59.39 & 1.818 \\
\hline & & 3c Shale & 49 & $3204-f t$ & 125 & $\begin{array}{r}800 \\
1200\end{array}$ & $\begin{array}{l}5.52 \\
8.28\end{array}$ & $\begin{array}{l}400 \\
600\end{array}$ & $\begin{array}{l}2.76 \\
4.14\end{array}$ & 74.46 & 1.947 \\
\hline \multirow[t]{3}{*}{4.} & $\begin{array}{l}(10 / 21 / 86- \\
10 / 31 / 86)\end{array}$ & 4a 011 Sand & 70 & $3280-\mathrm{ft}$ & 125 & 750 & 5.17 & 520 & 3.59 & 55.26 & ND \\
\hline & & 4b Shale & 49 & $3202-\mathrm{ft}$ & 125 & 750 & 5.17 & 460 & 3.17 & 69.37 & ND \\
\hline & & 4c Shale & 51 & $3207-\mathrm{ft}$ & 125 & \multicolumn{4}{|c|}{$\begin{array}{l}\text { Sample Jacket failed, } \\
\text { test not completed }\end{array}$} & 71.78 & ND \\
\hline \multirow[t]{3}{*}{5.} & $\begin{array}{l}(3 / 3 / 87- \\
4 / 16 / 87)\end{array}$ & 5a Shale & 49 & $3202-\mathrm{ft}$ & 125 & 800 & 5.52 & 445 & 3.07 & 85.16 & 1.926 \\
\hline & & 5b Shale & 51 & $3206-\mathrm{ft}$ & 125 & 800 & 5.52 & 430 & 2.97 & 78.65 & 1.920 \\
\hline & & 5c 011 Sand & 70 & $3278-f t$ & 125 & 800 & 5.52 & 380 & 2.62 & 40.68 & 1.893 \\
\hline
\end{tabular}


Table D.1.a - Dáta for test \#l

Faja shale, depth unknown

volume $=101.69 \mathrm{CC}, 25{ }^{\circ} \mathrm{C}$

Run started on $4 / 30 / 86$; ended on $5 / 27 / 86$

\section{Pressure in $\mathrm{MPa} \quad$ Volume in $\mathrm{cm}$ ?}

\begin{tabular}{llrrrrrr} 
Time/Hr & LOG $\mathrm{t}$ & $\mathrm{Pp}$ & $\mathrm{PC}$ & $\mathrm{Pe}$ & $\mathrm{Ref} . \mathrm{V}$ & $\nabla \mathrm{V}$ & $\mathrm{V} / \mathrm{V}_{0}$ \\
\hline 1.0 & 0 & 443.20 & 878.96 & 435.76 & 8.246 & 0 & 100 \\
47 & 1.67 & 412.72 & 917.96 & 505.24 & 3.368 & 4.879 & 95.20 \\
121 & 2.08 & 413.74 & 915.56 & 501.82 & 3.303 & 4.944 & 95.14 \\
137 & 2.14 & 412.72 & 911.96 & 499.24 & 3.290 & 4.957 & 95.13 \\
161 & 2.21 & 413.80 & 917.96 & 504.16 & 3.274 & 4.972 & 95.11 \\
208 & 2.32 & 553.84 & 1015.16 & 461.32 & 3.274 & 4.972 & 95.11 \\
216 & 2.33 & 613.18 & 1308.86 & 695.69 & 2.877 & 5.370 & 94.72 \\
235 & 2.37 & 613.48 & 1320.98 & 707.50 & 2.828 & 5.418 & 94.67 \\
283 & 2.45 & 617.26 & 1309.76 & 692.50 & 2.800 & 5.447 & 94.64 \\
291 & 2.46 & 680.68 & 1367.96 & 687.28 & 2.774 & 5.473 & 94.62 \\
307 & 2.49 & 615.16 & 1315.46 & 700.30 & 2.736 & 5.510 & 94.58 \\
330 & 2.52 & 613.06 & 1316.96 & 703.90 & 2.716 & 5.531 & 94.56 \\
363 & 2.56 & 669.10 & 1336.16 & 667.06 & 2.709 & 5.537 & 94.55 \\
383 & 2.58 & 828.88 & 1716.56 & 887.68 & 2.596 & 5.650 & 94.44 \\
430 & 2.63 & 832.36 & 1710.56 & 878.20 & 2.498 & 5.749 & 94.35 \\
454 & 2.66 & 831.46 & 1764.86 & 933.40 & 2.464 & 5.783 & 94.31 \\
640 & 2.81 & 810.28 & 1709.06 & 898.78 & 2.445 & 5.801 & 94.30
\end{tabular}


Table D.2.a - Data for Test 非a - FAJA Shale, 3309.6-ft depth Volume $=73.47 \mathrm{~cm}^{3}$, density $1.70 \mathrm{gm} / \mathrm{cm}^{3}, 25^{\circ} \mathrm{C}$

Run started on $7 / 14 / 86$; ended on $8 / 15 / 86$

Pressure in $\mathrm{MPa}$

Volume in $\mathrm{cm}^{3}$

\begin{tabular}{|c|c|c|c|c|c|c|c|}
\hline Time $/ \mathrm{Hr}$ & LOG $t$ & $\mathrm{Pp}$ & $P C$ & $\mathrm{Pe}$ & R. V & $\nabla \mathrm{V}$ & $V / V_{0}$ \\
\hline 1.6 & 0.20 & 319.9 & 542.4 & 222.5 & 4.435 & 0.268 & 99.635 \\
\hline 16.9 & 1.23 & 349.7 & 543.6 & 193.9 & 4.235 & 0.468 & 99.363 \\
\hline 21.6 & 1.33 & 329.5 & 553.6 & 224.1 & 4.071 & 0.632 & 99.140 \\
\hline 25.3 & 1.40 & 320.6 & 547.4 & 226.8 & 3.901 & 0.802 & 98.908 \\
\hline 41.0 & 1.61 & 324.7 & 541.7 & 217.0 & 3.587 & 1.116 & 98.481 \\
\hline 45.5 & 1.66 & 345.1 & 544.7 & 199.6 & 2.498 & 2.205 & 96.999 \\
\hline 49.0 & 1.69 & 327.6 & 548.6 & 221.0 & 3.417 & 1.286 & 98.250 \\
\hline 65.0 & 1.81 & 343.2 & 545.2 & 202.0 & 2.920 & 1.783 & 97.573 \\
\hline 73.0 & 1.86 & 321.3 & 546.4 & 225.1 & 2.798 & 1.905 & 97.407 \\
\hline 89.0 & 1.95 & 326.7 & 553.0 & 226.3 & 2.695 & 2.008 & 97.267 \\
\hline 98.0 & 1.99 & 381.7 & 545.2 & 163.5 & 2.647 & 2.056 & 97.202 \\
\hline 114.0 & 2.06 & 318.3 & 551.2 & 232.9 & 2.762 & 1.941 & 97.358 \\
\hline 122.0 & 2.09 & 319.7 & 549.1 & 229.4 & 2.716 & 1.987 & 97.295 \\
\hline 139.0 & 2.14 & 317.9 & 547.6 & 229.7 & 2.668 & 2.035 & 97.230 \\
\hline 147.0 & 2.17 & 306.1 & 544.7 & 238.6 & 2.653 & 2.050 & 97.210 \\
\hline 162.5 & 2.21 & 307.5 & 543.6 & 236.1 & 2.648 & 2.055 & 97.203 \\
\hline 186.5 & 2.27 & 636.8 & 1217.3 & 580.5 & 2.097 & 2.606 & 96.453 \\
\hline 195.0 & 2.29 & 627.0 & 1216.9 & 589.9 & 2.033 & 2.670 & 96.366 \\
\hline 211.0 & 2.32 & 617.9 & 1217.2 & 599.3 & 1.984 & 2.719 & 96.299 \\
\hline 219.0 & 2.34 & 622.3 & 1218.7 & 596.4 & 1.934 & 2.769 & 96.231 \\
\hline 239.0 & 2.38 & 678.6 & 1204.1 & 525.5 & 1.914 & 2.789 & 96.204 \\
\hline 243.0 & 2.39 & 613.7 & 1218.8 & 605.1 & 1.883 & 2.820 & 96.162 \\
\hline 259.0 & 2.41 & 615.6 & 1218.6 & 603.0 & 1.858 & 2.845 & 96.128 \\
\hline 267.0 & 2.43 & 582.9 & 1217.7 & 634.8 & 1.821 & 2.882 & 96.077 \\
\hline 283.0 & 2.45 & 605.7 & 1219.8 & 614.1 & 1.790 & 2.913 & 96.035 \\
\hline 291.0 & 2.46 & 622.3 & 1229.0 & 606.7 & 1.768 & 2.935 & 96.005 \\
\hline 307.5 & 2.49 & 604.7 & 1221.2 & 616.5 & 1.746 & 2.957 & 95.975 \\
\hline 314.0 & 2.50 & 579.7 & 1224.1 & 644.4 & 1.717 & 2.986 & 95.936 \\
\hline 329.5 & 2.52 & 605.8 & 1218.5 & 612.7 & 1.705 & 2.998 & 95.919 \\
\hline 337.5 & 2.53 & 606.3 & 1218.2 & 611.9 & 1.698 & 3.005 & 95.910 \\
\hline 401.5 & 2.60 & 605.2 & 1216.5 & 611.3 & 1.69 & 3.013 & 95.899 \\
\hline 409.5 & 2.61 & 605.4 & 1216.6 & 611.2 & 1.678 & 3.025 & 95.883 \\
\hline 433.5 & 2.64 & 604.5 & 1218.8 & 614.3 & 1.667 & 3.036 & 95.868 \\
\hline 449.5 & 2.65 & 602.7 & 1194.7 & 592.0 & 1.672 & 3.031 & 95.875 \\
\hline 473.5 & 2.68 & 603.3 & 1217.4 & 614.1 & 1.673 & 3.030 & 95.876 \\
\hline 474.5 & 2.68 & 805.4 & 1617.2 & 811.8 & 1.662 & 3.041 & 95.861 \\
\hline 477.5 & 2.68 & 807.7 & 1619.8 & 812.1 & 1.643 & 3.060 & 95.835 \\
\hline 481.5 & 2.68 & 809.8 & 1626.1 & 816.3 & 1.614 & 3.089 & 95.796 \\
\hline 497.5 & 2.70 & 800.3 & 1618.4 & 818.1 & 1.593 & 3.110 & 95.767 \\
\hline 506 & 2.70 & 807.4 & 1622.1 & 814.7 & 1.572 & 3.131 & 95.738 \\
\hline 569.5 & 2.76 & 802.8 & 1618.6 & 815.8 & 1.555 & 3.148 & 95.715 \\
\hline 578 & 2.76 & 806.8 & 1619.6 & 812.8 & 1.538 & 3.165 & 95.692 \\
\hline 593.5 & 2.77 & 804.5 & 1622.3 & 817.8 & 1.527 & 3.176 & 95.677 \\
\hline 602 & 2.78 & 809 & 1619.8 & 810.8 & 1.512 & 3.191 & 95.657 \\
\hline 617.5 & 2.79 & 805.2 & 1622.3 & 817.1 & 1.494 & 3.209 & 95.632 \\
\hline 626 & 2.80 & 803 & 1620.4 & 817.4 & 1.482 & 3.221 & 95.616 \\
\hline 650 & 2.81 & 805.6 & 1619.6 & 814.0 & 1.483 & 3.220 & 95.617 \\
\hline 666 & 2.82 & 797.8 & 1617.9 & 820.1 & 1.491 & 3.212 & 95.628 \\
\hline
\end{tabular}


Table D.2.b - Data for Test \#2b - FAJA Shale, 3206-ft depth Volume $=102.73 \mathrm{~cm}^{3}$, Density $1.97 \mathrm{gm} / \mathrm{cm}^{3}, 25^{\circ} \mathrm{C}$

Run started on $7 / 14 / 86$; ended on $8 / 15 / 86$

Pressure in $\mathrm{MPa}$

Volume in $\mathrm{cm}^{3}$

\begin{tabular}{|c|c|c|c|c|c|c|c|}
\hline Time $/ \mathrm{Hr}$ & LOG $t$ & Pp & Pc & $\mathrm{Pe}$ & R. V & $\nabla V$ & $V / V_{0}$ \\
\hline 1.6 & 0.20 & 370.8 & 542.4 & 171.6 & 2.822 & -0.015 & 100.015 \\
\hline 16.9 & 1.23 & 371.1 & 543.6 & 172.5 & 2.853 & -0.046 & 100.045 \\
\hline 21.6 & 1.33 & 371.2 & 553.6 & 182.4 & 2.850 & -0.043 & 100.042 \\
\hline 25.3 & 1.40 & 372.2 & 547.4 & 175.2 & 2.856 & -0.049 & 100.048 \\
\hline 41.0 & 1.61 & 370.8 & 541.7 & 170.9 & 2.895 & -0.088 & 100.086 \\
\hline 45.5 & 1.66 & 373.6 & 544.7 & 171.1 & 2.905 & -0.098 & 100.095 \\
\hline 49.0 & 1.69 & 372.8 & 548.6 & 175.8 & 2.897 & -0.090 & 100.088 \\
\hline 65.0 & 1.81 & 373.6 & 545.2 & 171.6 & 2.925 & -0.118 & 100.115 \\
\hline 73.0 & 1.86 & 372.1 & 546.4 & 174.3 & 2.920 & -0.113 & 100.110 \\
\hline 89.0 & 1.95 & 371.8 & 553.0 & 181.2 & 2.928 & -0.121 & 100.118 \\
\hline 98.0 & 1.99 & 372.1 & 545.2 & 173.1 & 2.936 & -0.129 & 100.126 \\
\hline 114.0 & 2.06 & 374.5 & 551.2 & 176.7 & 2.949 & -0.142 & 100.138 \\
\hline 122.0 & 2.09 & 373.7 & 549.1 & 175.4 & 2.943 & -0.136 & 100.132 \\
\hline 139.0 & 2.14 & 369.9 & 547.6 & 177.7 & 2.943 & -0.136 & 100.132 \\
\hline 147.0 & 2.17 & 371.9 & 544.7 & 172.8 & 2.953 & -0.146 & 100.142 \\
\hline 162.5 & 2.21 & 371.6 & 543.6 & 172.0 & 2.969 & -0.162 & 100.158 \\
\hline 186.5 & 2.27 & 602.1 & 1217.3 & 615.2 & 2.247 & 0.560 & 99.455 \\
\hline 195.0 & 2.29 & 603.4 & 1216.9 & 613.5 & 2.215 & 0.592 & 99.424 \\
\hline 211.0 & 2.32 & 601.0 & 1217.2 & 616.2 & 2.203 & 0.604 & 99.412 \\
\hline 219.0 & 2.34 & 600.8 & 1218.7 & 617.9 & 2.186 & 0.621 & 99.396 \\
\hline 239.0 & 2.38 & 594.8 & 1204.1 & 609.3 & 2.180 & 0.627 & 99.390 \\
\hline 243.0 & 2.39 & 601.8 & 1218.8 & 617.0 & 2.170 & 0.637 & 99.380 \\
\hline 259.0 & 2.41 & 601.7 & 1218.6 & 616.9 & 2.165 & 0.642 & 99.375 \\
\hline 267.0 & 2.43 & 602.3 & 1217.7 & 615.4 & 2.149 & 0.658 & 99.359 \\
\hline 283.0 & 2.45 & 602.3 & 1219.8 & 617.5 & 2.135 & 0.672 & 99.346 \\
\hline 291.0 & 2.46 & 604.0 & 1229.0 & 625.0 & 2.120 & 0.687 & 99.331 \\
\hline 307.5 & 2.49 & 601.8 & 1221.2 & 619.4 & 2.113 & 0.694 & 99.324 \\
\hline 314.0 & 2.50 & 602.3 & 1224.1 & 621.8 & 2.099 & 0.708 & 99.311 \\
\hline 329.5 & 2.52 & 600.7 & 1218.5 & 617.8 & 2.095 & 0.712 & 99.307 \\
\hline 337.5 & 2.53 & 601.5 & 1218.2 & 616.7 & 2.089 & 0.718 & 99.301 \\
\hline 401.5 & 2.60 & 601.4 & 1216.5 & 615.1 & 2.086 & 0.721 & 99.298 \\
\hline 409.5 & 2.61 & 601.5 & 1216.6 & 615.1 & 2.074 & 0.733 & 99.286 \\
\hline 433.5 & 2.64 & 601.7 & 1218.8 & 617.1 & 2.072 & 0.735 & 99.285 \\
\hline 449.5 & 2.65 & 601.0 & 1194.7 & 593.7 & 2.086 & 0.721 & 99.298 \\
\hline 473.5 & 2.68 & 600.9 & 1217.4 & 616.5 & 2.086 & 0.721 & 99.298 \\
\hline 474.5 & 2.68 & 803.9 & 1617.2 & 813.3 & 1.962 & 0.845 & 99.177 \\
\hline 477.5 & 2.68 & 803.8 & 1619.8 & 816.0 & 1.933 & 0.874 & 99.149 \\
\hline 481.5 & 2.68 & 803.7 & 1626.1 & 822.4 & 1.898 & 0.909 & 99.115 \\
\hline 497.5 & 2.70 & 801.4 & 1618.4 & 817.0 & 1.874 & 0.933 & 99.092 \\
\hline 506.0 & 2.70 & 799.0 & 1622.1 & 823.1 & 1.841 & 0.966 & 99.060 \\
\hline 569.5 & 2.76 & 801.2 & 1618.6 & 817.4 & 1.814 & 0.993 & 99.033 \\
\hline 578.0 & 2.76 & 801.5 & 1619.6 & 818.1 & 1.793 & 1.014 & 99.013 \\
\hline 593.5 & 2.77 & 799.9 & 1622.3 & 822.4 & 1.786 & 1.021 & 99.006 \\
\hline 602.0 & 2.78 & 801.2 & 1619.8 & 818.6 & 1.769 & 1.038 & 98.990 \\
\hline 617.5 & 2.79 & 798.7 & 1622.3 & 823.6 & 1.754 & 1.053 & 98.975 \\
\hline 626.0 & 2.80 & 799.9 & 1620.4 & 820.5 & 1.744 & 1.063 & 98.965 \\
\hline 650.0 & 2.81 & 801.2 & 1619.6 & 818.4 & 1.743 & 1.064 & 98.964 \\
\hline 666.0 & 2.82 & 798.9 & 1617.9 & 819.0 & 1.756 & 1.051 & 98.977 \\
\hline
\end{tabular}


Table D.2.C - Data for Test \#2C - FAJA Oil Sand, 3280-ft depth Volume $=72.26 \mathrm{~cm}^{3}$, Density $1.85 \mathrm{gm} / \mathrm{cm}^{3}, 25^{\circ} \mathrm{C}$

Run started on $7 / 14 / 86$; ended on $8 / 15 / 86$

Pressure in $\mathrm{MPa} \quad$ Volume in $\mathrm{cm}^{3}$

\begin{tabular}{|c|c|c|c|c|c|c|c|}
\hline Time/Hr & LOG $t$ & $\mathrm{Pp}$ & Pc & $\mathrm{Pe}$ & R. V & $\nabla v$ & $V / V_{0}$ \\
\hline 1.6 & 0.20 & 371.9 & 542.4 & 170.5 & 5.261 & -0.027 & 100.037 \\
\hline 16.9 & 1.23 & 379.8 & 543.6 & 163.8 & 5.311 & -0.077 & 100.107 \\
\hline 21.6 & 1.33 & 382.1 & 553.6 & 171.5 & 5.312 & -0.078 & 100.108 \\
\hline 25.3 & 1.40 & 383.7 & 547.4 & 163.7 & 5.318 & -0.084 & 100.116 \\
\hline 41.0 & 1.61 & 378.9 & 541.7 & 162.8 & 5.352 & -0.118 & 100.163 \\
\hline 45.5 & 1.66 & 382.5 & 544.7 & 162.2 & 5.362 & -0.128 & 100.177 \\
\hline 49.0 & 1.69 & 385.0 & 548.6 & 163.6 & 5.357 & -0.123 & 100.170 \\
\hline 65.0 & 1.81 & 385.2 & 545.2 & 160.0 & 5.385 & -0.151 & 100.209 \\
\hline 73.0 & 1.86 & 385.2 & 546.4 & 161.2 & 5.381 & -0.147 & 100.203 \\
\hline 89.0 & 1.95 & 384.1 & 553.0 & 168.9 & 5.386 & -0.152 & 100.210 \\
\hline 98.0 & 1.99 & 381.7 & 545.2 & 163.5 & 5.393 & -0.159 & 100.220 \\
\hline 114.0 & 2.06 & 386.6 & 551.2 & 164.6 & 5.392 & -0.158 & 100.219 \\
\hline 122.0 & 2.09 & 386.5 & 549.1 & 162.6 & 5.385 & -0.151 & 100.209 \\
\hline 139.0 & 2.14 & 374.8 & 547.6 & 172.8 & 4.955 & 0.279 & 99.614 \\
\hline 147.0 & 2.17 & 383.9 & 544.7 & 160.8 & 4.968 & 0.266 & 99.632 \\
\hline 162.5 & 2.21 & 381.1 & 543.6 & 162.5 & 4.988 & 0.246 & 99.660 \\
\hline 186.5 & 2.27 & 586.3 & 1217.3 & 631.0 & 4.973 & 0.261 & 99.639 \\
\hline 195.0 & 2.29 & 587.3 & 1216.9 & 629.6 & 4.767 & 0.467 & 99.354 \\
\hline 211.0 & 2.32 & 578.4 & 1217.2 & 638.8 & 4.760 & 0.474 & 99.344 \\
\hline 219.0 & 2.34 & 582.5 & 1218.7 & 636.2 & 4.747 & 0.487 & 99.326 \\
\hline 239.0 & 2.38 & 570.6 & 1204.1 & 633.5 & 4.757 & 0.477 & 99.340 \\
\hline 243.0 & 2.39 & 582.9 & 1218.8 & 635.9 & 4.752 & 0.482 & 99.333 \\
\hline 259.0 & 2.41 & 582.8 & 1218.6 & 635.8 & 4.752 & 0.482 & 99.333 \\
\hline 267.0 & 2.43 & 581.8 & 1217.7 & 635.9 & 4.735 & 0.499 & 99.309 \\
\hline 283.0 & 2.45 & 584.5 & 1219.8 & 635.3 & 4.729 & 0.505 & 99.301 \\
\hline 291.0 & 2.46 & 582.4 & 1229.0 & 646.6 & 4.709 & 0.525 & 99.273 \\
\hline 307.5 & 2.49 & 582.9 & 1221.2 & 638.3 & 4.710 & 0.524 & 99.275 \\
\hline 314.0 & 2.50 & 582.5 & 1224.1 & 641.6 & 4.694 & 0.540 & 99.253 \\
\hline 329.5 & 2.52 & 583.7 & 1218.5 & 634.8 & 4.698 & 0.536 & 99.258 \\
\hline 337.5 & 2.53 & 583.4 & 1218.2 & 634.8 & 4.694 & 0.540 & 99.253 \\
\hline 401.5 & 2.60 & 583.2 & 1216.5 & 633.3 & 4.704 & 0.530 & 99.267 \\
\hline 409.5 & 2.61 & 583.6 & 1216.6 & 633.0 & 4.692 & 0.542 & 99.250 \\
\hline 433.5 & 2.64 & 583.6 & 1218.8 & 635.2 & 4.697 & 0.537 & 99.257 \\
\hline 449.5 & 2.65 & 582.0 & 1219.0 & 637.0 & 4.717 & 0.517 & 99.285 \\
\hline 473.5 & 2.68 & 582.2 & 1217.4 & 635.2 & 4.722 & 0.512 & 99.291 \\
\hline 474.5 & 2.68 & 785.3 & 1617.2 & 831.9 & 4.622 & 0.612 & 99.153 \\
\hline 477.5 & 2.68 & 788.9 & 1619.8 & 830.9 & 4.603 & 0.631 & 99.127 \\
\hline 481.5 & 2.68 & 784.4 & 1626.1 & 841.7 & 4.573 & 0.661 & 99.085 \\
\hline 497.5 & 2.70 & 786.2 & 1618.4 & 832.2 & 4.567 & 0.667 & 99.077 \\
\hline 506.0 & 2.70 & 784.7 & 1622.1 & 837.4 & 4.542 & 0.692 & 99.042 \\
\hline 569.5 & 2.76 & 783.5 & 1618.6 & 835.1 & 4.534 & 0.700 & 99.031 \\
\hline 578.0 & 2.76 & 785.0 & 1619.6 & 834.6 & 4.517 & 0.717 & 99.008 \\
\hline 593.5 & 2.77 & 780.0 & 1622.3 & 842.3 & 4.516 & 0.718 & 99.006 \\
\hline 602.0 & 2.78 & 784.7 & 1619.8 & 835.1 & 4.501 & 0.733 & 98.986 \\
\hline 617.5 & 2.79 & 783.3 & 1622.3 & 839.0 & 4.492 & 0.742 & 98.973 \\
\hline 626.0 & 2.80 & 783.2 & 1620.4 & 837.2 & 4.484 & 0.750 & 98.962 \\
\hline 650.0 & 2.81 & 784.7 & 1619.6 & 834.9 & 4.490 & 0.744 & 98.970 \\
\hline 666.0 & 2.82 & 777.8 & 1617.9 & 840.1 & 4.509 & 0.725 & 98.997 \\
\hline
\end{tabular}


Table D.2.d. Summary Data for Creep Test \#2

\begin{tabular}{lll}
\hline Sample & $P_{E}$ & Slope, $\times 10^{-3} \mathrm{~s}^{-1}$ \\
\hline Shale, $3309 \mathrm{ft}$ & $200 \mathrm{psi}(1.38 \mathrm{MPa})$ & -20.0 \\
& $600 \mathrm{psi}(4.14 \mathrm{MPa})$ & -19.91 \\
& $800 \mathrm{psi}(5.52 \mathrm{MPa})$ & -11.69 \\
Shale, 3206 ft & $175 \mathrm{psi}(1.21 \mathrm{MPa})$ & +1.15 \\
& $615 \mathrm{psi}(4.24 \mathrm{MPa})$ & -4.24 \\
& $820 \mathrm{psi}(5.44 \mathrm{MPa})$ & -8.65 \\
Dil-sand, $3280 \mathrm{ft}$ & $165 \mathrm{psi}(1.10 \mathrm{MPa})$ & Positive slope \\
& $635 \mathrm{psi}(4.21 \mathrm{MPa})$ & -3.63 \\
& $836 \mathrm{psi}(5.55 \mathrm{MPa})$ & -8.06
\end{tabular}

Note that the slope values for the 3309-ft shale sample are much higher than the other samples; this can also be seen in the plotted data (Figure 2a). 
Table D.3.a - Data for Test \#3a - FAJA SHALE, 3202-FT DEPTH, Core \#49 VDLUME $=78.1 \mathrm{~cm}^{3}$, DENSITY $2.07 \mathrm{gm} / \mathrm{cm}^{3}, 125^{\circ} \mathrm{C}$.

Run started on $9 / 3 / 87$; ended on $10 / 13 / 87$

Pressure in $\mathrm{MPa} \quad$ Volume in $\mathrm{cm}^{3}$

\begin{tabular}{|c|c|c|c|c|c|c|c|}
\hline Time $/ \mathrm{HI}$ & LOG $t$ & $\mathrm{Pp}$ & Pc & $\mathrm{Pe}$ & R. $V$ & $\nabla V$ & $V / V_{0}$ \\
\hline 119.5 & 2.08 & 1.407 & 5.547 & 4.140 & 4.918 & -1.060 & 101.476 \\
\hline 127.5 & 2.11 & 2.230 & 5.541 & 3.311 & 5.172 & -1.314 & 101.830 \\
\hline 143.5 & 2.16 & 2.439 & 5.597 & 3.158 & 5.315 & -1.457 & 102.029 \\
\hline 151.5 & 2.18 & 1.867 & 5.448 & 3.581 & 5.580 & -1.722 & 102.398 \\
\hline 167.5 & 2.22 & 1.804 & 5.546 & 3.742 & 5.733 & -1.875 & 102.611 \\
\hline 175.5 & 2.24 & 2.451 & 5.491 & 3.040 & 6.018 & -2.160 & 103.008 \\
\hline 191.5 & 2.28 & 1.806 & 5.477 & 3.671 & 6.145 & -2.287 & 103.185 \\
\hline 199.5 & 2.30 & 3.718 & 5.372 & 1.654 & 6.322 & -2.464 & 103.432 \\
\hline 215.5 & 2.33 & 2.004 & 5.428 & 3.424 & 6.528 & -2.670 & 103.719 \\
\hline 223.5 & 2.35 & 2.203 & 5.374 & 3.171 & 6.666 & -2.808 & 103.911 \\
\hline 288.5 & 2.46 & 1.697 & 5.494 & 3.797 & 6.925 & -3.067 & 104.272 \\
\hline 296.5 & 2.47 & 3.026 & 5.565 & 2.539 & 7.102 & -3.244 & 104.518 \\
\hline 311.5 & 2.49 & 2.242 & 5.505 & 3.263 & 7.283 & -3.425 & 104.770 \\
\hline 320.5 & 2.51 & 3.267 & 5.461 & 2.194 & 7.487 & -3.629 & 105.054 \\
\hline 336.5 & 2.53 & 2.222 & 5.498 & 3.276 & 7.676 & -3.818 & 105.318 \\
\hline 344.5 & 2.54 & 4.664 & 5.565 & 0.901 & 7.933 & -4.075 & 105.675 \\
\hline 359.5 & 2.56 & 2.339 & 5.498 & 3.159 & 8.172 & -4.314 & 106.008 \\
\hline 368.5 & 2.57 & 4.396 & 5.509 & 1.113 & 8.347 & -4.489 & 106.252 \\
\hline 384.5 & 2.58 & 3.869 & 5.517 & 1.648 & 8.586 & -4.728 & 106.585 \\
\hline 392.5 & 2.59 & 3.488 & 5.520 & 2.032 & 8.843 & -4.985 & 106.943 \\
\hline 460.0 & 2.66 & 4.184 & 5.351 & 1.167 & 10.105 & -6.247 & 108.701 \\
\hline 479.0 & 2.68 & 2.744 & 5.662 & 2.918 & 10.105 & -6.247 & 108.701 \\
\hline 503.0 & 2.70 & 4.375 & 5.494 & 1.119 & 11.010 & -7.152 & 109.961 \\
\hline 527.0 & 2.72 & 2.448 & 5.550 & 3.102 & 11.449 & -7.591 & 110.572 \\
\hline 551.0 & 2.74 & $2: 515$ & 5.511 & 2.996 & 11.659 & -7.801 & 110.865 \\
\hline 552.5 & 2.74 & 4.154 & 8.232 & 4.078 & 11.727 & -7.869 & 110.960 \\
\hline 554.5 & 2.74 & 4.029 & 8.254 & 4.225 & 11.765 & -7.907 & 111.013 \\
\hline 555.5 & 2.74 & 4.040 & 8.287 & 4.247 & 11.796 & -7.938 & 111.056 \\
\hline 558.5 & 2.75 & 4.111 & 8.383 & 4.272 & 11.863 & -8.005 & 111.149 \\
\hline 624.5 & 2.80 & 2.865 & 8.213 & 5.348 & 12.001 & -8.143 & 111.341 \\
\hline 648 & 2.81 & 3.512 & 8.274 & 4.762 & 12.142 & -8.284 & 111.538 \\
\hline 671 & 2.83 & 3.722 & 8.341 & 4.619 & 12.277 & -8.419 & 111.726 \\
\hline 697 & 2.84 & 3.171 & 8.320 & 5.149 & 12.404 & -8.546 & 111.903 \\
\hline 744 & 2.87 & 3.578 & 8.299 & 4.721 & 12.529 & -8.671 & 112.077 \\
\hline 791 & 2.90 & 3.686 & 8.250 & 4.564 & 12.651 & -8.793 & 112.247 \\
\hline 814 & 2.91 & 3.126 & 8.032 & 4.906 & 12.886 & -9.028 & 112.574 \\
\hline 838 & 2.92 & 3.51 & 8.290 & 4.780 & 13.25 & -9.392 & 113.081 \\
\hline 861.5 & 2.94 & 4.185 & 8.285 & 4.100 & 13.46 & -9.605 & 113.377 \\
\hline 885.5 & 2.95 & 3.908 & 8.262 & 4.354 & 13.626 & -9.768 & 113.604 \\
\hline 951 & 2.98 & 4.357 & 8.279 & 3.922 & 14.279 & -10.421 & 114.514 \\
\hline
\end{tabular}


Table 0.3.b - Data for Test 非b - FAJA Oil Sand, 3280-FT DEPTH, Core $\|_{70}$ VOLUME $=59.39 \mathrm{~cm}^{3}$, DENSITY $1.82 \mathrm{gm} / \mathrm{cm}^{3}, 125^{\circ} \mathrm{C}$

Run started on $9 / 3 / 87$; ended on $10 / 13 / 87$

Pressure in $\mathrm{MPa} \quad$ Volume in $\mathrm{cm}^{3}$

\begin{tabular}{|c|c|c|c|c|c|c|c|}
\hline Time/HI & LOG $t$ & $\mathrm{Pp}$ & $P C$ & $\mathrm{Pe}$ & R. V & $\nabla \vee$ & $V / V_{0}$ \\
\hline 119.5 & 2.08 & 3.607 & 5.547 & 1.940 & 0.065 & 0.053 & 99.911 \\
\hline 127.5 & 2.11 & 3.307 & 5.541 & 2.234 & -0.005 & 0.123 & 99.793 \\
\hline 143.5 & 2.16 & 2.863 & 5.597 & 2.734 & -0.047 & 0.165 & 99.722 \\
\hline 151.5 & 2.18 & 3.073 & 5.448 & 2.375 & -0.360 & 0.478 & 99.195 \\
\hline 167.5 & 2.22 & 3.208 & 5.546 & 2.338 & -0.401 & 0.519 & 99.126 \\
\hline 175.5 & 2.24 & 3.036 & 5.491 & 2.455 & -0.239 & 0.357 & 99.399 \\
\hline 191.5 & 2.28 & 3.110 & 5.477 & 2.367 & -0.276 & 0.394 & 99.337 \\
\hline 199.5 & 2.30 & 2.992 & 5.372 & 2.380 & -0.340 & 0.458 & 99.229 \\
\hline 215.5 & 2.33 & 2.924 & 5.428 & 2.504 & -0.379 & 0.497 & 99.163 \\
\hline 223.5 & 2.35 & 2.871 & 5.374 & 2.503 & -0.433 & 0.551 & 99.072 \\
\hline 288.5 & 2.46 & 3.347 & 5.494 & 2.147 & -0.489 & 0.607 & 98.978 \\
\hline 296.5 & 2.47 & 3.296 & 5.565 & 2.269 & -0.555 & 0.673 & 98.867 \\
\hline 311.5 & 2.49 & 3.051 & 5.505 & 2.454 & -0.600 & 0.718 & 98.791 \\
\hline 320.5 & 2.51 & 3.239 & 5.461 & 2.222 & -0.666 & 0.784 & 98.680 \\
\hline 336.5 & 2.53 & 3.053 & 5.498 & 2.445 & -0.708 & 0.826 & 98.609 \\
\hline 344.5 & 2.54 & 3.082 & 5.565 & 2.483 & -0.763 & 0.881 & 98.517 \\
\hline 359.5 & 2.56 & 2.781 & 5.498 & 2.717 & -0.806 & 0.924 & 98.444 \\
\hline 368.5 & 2.57 & 3.044 & 5.509 & 2.465 & -0.865 & 0.983 & 98.345 \\
\hline 384.5 & 2.58 & 3.285 & 5.517 & 2.232 & -0.911 & 1.029 & 98.267 \\
\hline 392.5 & 2.59 & 3.232 & 5.520 & 2.288 & -0.962 & 1.080 & 98.182 \\
\hline 460.0 & 2.66 & 3.480 & 5.351 & 1.871 & -1.007 & 1.125 & 98.106 \\
\hline 479.0 & 2.68 & 3.130 & 5.662 & 2.532 & -1.325 & 1.443 & 97.570 \\
\hline 503.0 & 2.70 & 2.901 & 5.494 & 2.593 & -1.427 & 1.545 & 97.399 \\
\hline 527.0 & 2.72 & 2.894 & 5.550 & 2.656 & -1.509 & 1.627 & 97.260 \\
\hline 551.0 & 2.74 & 2.841 & 5.511 & 2.670 & -1.591 & 1.709 & 97.122 \\
\hline 552.5 & 2.74 & 4.280 & 8.232 & 3.952 & -1.582 & 1.700 & 97.138 \\
\hline 554.5 & 2.74 & 4.234 & 8.254 & 4.020 & -1.601 & 1.719 & 97.106 \\
\hline 555.5 & 2.74 & 4.252 & 8.287 & 4.035 & -1.644 & 1.762 & 97.033 \\
\hline 558.5 & 2.75 & 4.063 & 8.383 & 4.320 & -1.655 & 1.773 & 97.015 \\
\hline 624.5 & 2.80 & 4.808 & 8.213 & 3.405 & -1.729 & 1.847 & 96.890 \\
\hline 648 & 2.81 & 4.667 & 8.274 & 3.607 & -1.798 & 1.916 & 96.774 \\
\hline 671 & 2.83 & 4.343 & 8.341 & 3.998 & -1.631 & 1.749 & 97.055 \\
\hline 697 & 2.84 & 5.025 & 8.320 & 3.295 & -1.927 & 2.045 & 96.557 \\
\hline 744 & 2.87 & 4.501 & 8.299 & 3.798 & -1.994 & 2.112 & 96.444 \\
\hline 791 & 2.90 & 4.806 & 8.250 & 3.444 & -1.847 & 1.965 & 96.691 \\
\hline 814 & 2.91 & 4.8 & 8.032 & 3.208 & -2.001 & 2.119 & 96.432 \\
\hline 838 & 2.92 & 4.4 & 8.290 & 3.896 & -2.375 & 2.493 & 95.802 \\
\hline 861.5 & 2.94 & 4.3 & 8.285 & 4.000 & -2.471 & 2.589 & 95.641 \\
\hline 885.5 & 2.95 & 4.112 & 8.262 & 4.150 & -2.308 & 2.426 & 95.915 \\
\hline 951 & 2.98 & 4.189 & 8.279 & 4.090 & -2.401 & 2.519 & 95.759 \\
\hline
\end{tabular}


Table D.3.C - Data for Test 非C - FAJA Shale, 3204-FT DEPTH, Core 非49 VOLUME $=.74 .46 \mathrm{~cm}^{3}$, DENSITY $1.95 \mathrm{gm} / \mathrm{cm}^{3}, 125^{\circ} \mathrm{C}$

Run started on $9 / 3 / 87$; ended on $10 / 13 / 87$

Pressure in $\mathrm{MPa}$

Volume in $\mathrm{cm}^{3}$

\begin{tabular}{|c|c|c|c|c|c|c|c|}
\hline Time/Hr & LOG $t$ & $P p$ & Pc & $\mathrm{Pe}$ & R. $V$ & $\nabla V$ & $V / V_{0}$ \\
\hline $\begin{array}{l}119.5 \\
127.5\end{array}$ & $\begin{array}{l}2.08 \\
2.11\end{array}$ & $\begin{array}{l}2.679 \\
2.602\end{array}$ & $\begin{array}{l}5.547 \\
5.541\end{array}$ & $\begin{array}{l}2.868 \\
2.939\end{array}$ & $\begin{array}{l}3.272 \\
3.315\end{array}$ & $\begin{array}{l}-2.116 \\
-2.159\end{array}$ & $\begin{array}{l}102.842 \\
102.900\end{array}$ \\
\hline 143.5 & 2.16 & 2.736 & 5.597 & 2.861 & 3.177 & -2.021 & 102.714 \\
\hline 151.5 & 2.18 & 2.706 & 5.448 & 2.742 & 3.233 & -2.077 & 102.789 \\
\hline 167.5 & 2.22 & 2.662 & 5.546 & 2.884 & 3.277 & -2.121 & 102.849 \\
\hline 175.5 & 2.24 & 2.719 & 5.491 & 2.772 & 3.307 & -2.151 & 102.889 \\
\hline 191.5 & 2.28 & 2.721 & 5.477 & 2.756 & 3.350 & -2.194 & 102.947 \\
\hline 199.5 & 2.30 & 2.720 & 5.372 & 2.652 & 3.369 & -2.213 & 102.972 \\
\hline 215.5 & 2.33 & 2.737 & 5.428 & 2.691 & 3.400 & -2.244 & 103.014 \\
\hline 223.5 & 2.35 & 2.755 & 5.374 & 2.619 & 3.418 & -2.262 & 103.038 \\
\hline 288.5 & 2.46 & 2.868 & 5.494 & 2.626 & 3.477 & -2.321 & 103.117 \\
\hline 296.5 & 2.47 & 2.806 & 5.565 & 2.759 & 3.466 & -2.310 & 103.102 \\
\hline 311.5 & 2.49 & 2.785 & 5.505 & 2.720 & 3.477 & -2.321 & 103.117 \\
\hline 320.5 & 2.51 & 2.767 & 5.461 & 2.694 & 3.475 & -2.319 & 103.114 \\
\hline 336.5 & 2.53 & 2.782 & 5.498 & 2.716 & 3.481 & -2.325 & 103.122 \\
\hline 344.5 & 2.54 & 2.792 & 5.565 & 2.773 & 3.476 & -2.320 & 103.116 \\
\hline 359.5 & 2.56 & 2.740 & 5.498 & 2.758 & 3.475 & -2.319 & 103.114 \\
\hline 368.5 & 2.57 & 2.744 & 5.509 & 2.765 & 3.476 & -2.320 & 103.116 \\
\hline 384.5 & 2.58 & 2.784 & 5.517 & 2.733 & 3.476 & -2.320 & 103.116 \\
\hline 392.5 & 2.59 & 2.748 & 5.520 & 2.772 & 3.476 & -2.320 & 103.116 \\
\hline 460.0 & 2.66 & 2.695 & 5.351 & 2.656 & 3.477 & -2.321 & 103.117 \\
\hline 479.0 & 2.68 & 3.057 & 5.662 & 2.605 & 3.487 & -2.331 & 103.131 \\
\hline 503.0 & 2.70 & 2.780 & 5.494 & 2.714 & 3.463 & -2.307 & 103.098 \\
\hline 527.0 & 2.72 & 2.763 & 5.550 & 2.787 & 3.460 & -2.304 & 103.094 \\
\hline 551.0 & 2.74 & 2.777 & 5.511 & 2.734 & 3.466 & -2.310 & 103.102 \\
\hline 552.5 & 2.74 & 4.200 & 8.232 & 4.032 & 3.427 & -2.271 & 103.050 \\
\hline 554.5 & 2.74 & 4.134 & 8.254 & 4.120 & 3.419 & -2.263 & 103.039 \\
\hline 555.5 & 2.74 & 4.164 & 8.287 & 4.123 & 3.417 & -2.261 & 103.037 \\
\hline 558.5 & 2.75 & 4.217 & 8.383 & 4.166 & 3.413 & -2.257 & 103.031 \\
\hline 624.5 & 2.80 & 4.138 & 8.213 & 4.075 & 3.405 & -2.249 & 103.020 \\
\hline 648 & 2.81 & 4.147 & 8.274 & 4.127 & 3.404 & -2.248 & 103.019 \\
\hline 671 & 2.83 & 4.155 & 8.341 & 4.186 & 3.403 & -2.247 & 103.018 \\
\hline 697 & 2.84 & 4.114 & 8.320 & 4.206 & 3.396 & -2.240 & 103.008 \\
\hline 744 & 2.87 & 4.146 & 8.299 & 4.153 & 3.400 & -2.244 & 103.014 \\
\hline 791 & 2.90 & 4.165 & 8.250 & 4.085 & 3.400 & -2.244 & 103.014 \\
\hline 814 & 2.91 & 3.982 & 8.032 & 4.050 & 3.396 & -2.240 & 103.008 \\
\hline 838 & 2.92 & 4.095 & 8.290 & 4.195 & 3.711 & -2.555 & 103.431 \\
\hline 861.5 & 2.94 & 4.139 & 8.285 & 4.146 & 3.762 & -2.606 & 103.500 \\
\hline 885.5 & 2.95 & 4.174 & 8.262 & 4.088 & 3.782 & -2.626 & 103.527 \\
\hline 951 & 2.98 & 4.145 & 8.279 & 4.134 & 3.803 & -2.647 & 103.555 \\
\hline
\end{tabular}


Table 0.4.a - Data for Test 非a - FAJA Sandstone, 3280-FT DEPTH, Core 非70 VOLUME $=55.26 \mathrm{~cm}^{3}, 125^{\circ} \mathrm{C}$

Run started on 10/21/87; ended on 10/31/87

Pressure in $\mathrm{MPa} \quad$ Volume in $\mathrm{cm}^{3}$

$\begin{array}{llllllll}\text { Time/HI } & \text { LOG } \mathrm{t} & \mathrm{Pp} & \mathrm{PC} & \mathrm{Pe} & \mathrm{R} . \mathrm{V} & \nabla V & V / V_{0} \\ 2.0 & 0.30 & 3.000 & 5.583 & 2.583 & -0.359 & 0.255 & 99.539 \\ 3.0 & 0.48 & 4.174 & 5.915 & 1.741 & -0.841 & 0.737 & 98.666 \\ 4.0 & 0.60 & 4.995 & 5.305 & 0.310 & -0.733 & 0.629 & 98.862 \\ 5.0 & 0.70 & 4.982 & 5.075 & 0.093 & -0.919 & 0.815 & 98.525 \\ 6.5 & 0.81 & 4.486 & 5.813 & 1.327 & -1.170 & 1.066 & 98.071 \\ 9.5 & 0.98 & 3.118 & 5.582 & 2.464 & -1.371 & 1.267 & 97.707 \\ 21.5 & 1.33 & 2.842 & 5.384 & 2.542 & -1.375 & 1.271 & 97.700 \\ 29.5 & 1.47 & 2.763 & 5.558 & 2.795 & -1.390 & 1.286 & 97.673 \\ 45.5 & 1.66 & 2.666 & 5.470 & 12.804 & -1.393 & 1.289 & 97.667 \\ 59.5 & 1.77 & 2.661 & 4.867 & 2.206 & -1.397 & 1.293 & 97.660 \\ 75.5 & 1.88 & 2.725 & 4.967 & 2.242 & -1.391 & 1.287 & 97.671 \\ 82.5 & 1.92 & 2.888 & 5.025 & 2.137 & -1.399 & 1.295 & 97.657 \\ 147.5 & 2.17 & 4.586 & 4.957 & 0.371 & -1.426 & 1.322 & 97.608 \\ 153.5 & 2.19 & 3.307 & 5.032 & 1.725 & -1.556 & 1.452 & 97.372 \\ 169.5 & 2.23 & 2.573 & 4.904 & 2.331 & -1.878 & 1.774 & 96.790 \\ 177.5 & 2.25 & 4.317 & 5.053 & 0.736 & -1.990 & 1.886 & 96.587 \\ 194.5 & 2.29 & 4.109 & 4.882 & 0.773 & -2.036 & 1.932 & 96.504 \\ 217.5 & 2.34 & 4.622 & 4.933 & 0.311 & -2.536 & 2.432 & 95.599 \\ 222.5 & 2.35 & 3.137 & 4.867 & 1.730 & -3.304 & 3.200 & 94.209 \\ 241.5 & 2.38 & 3.841 & 4.959 & 1.118 & -3.291 & 3.187 & 94.233\end{array}$


Tabel D.4.b - Data for Test 非b - FAJA SHALE, 3202-FT DEPTH, Core 1 非 9 VOLUME $=69.37 \mathrm{~cm}^{3}, 125{ }^{\circ} \mathrm{C}$

Run started on 10/21/87; ended on 10/31/87

Pressure in $\mathrm{MPa}$

Volume in $\mathrm{cm}^{3}$

\begin{tabular}{llllllll} 
Time/Hr & LOG $\mathrm{t}$ & $\mathrm{Pp}$ & $\mathrm{PC}$ & $\mathrm{Pe}$ & $\mathrm{R} . \mathrm{V}$ & $\nabla \mathrm{V}$ & $\mathrm{V} / \mathrm{V}_{\mathrm{O}}$ \\
\hline 2.0 & 0.30 & 3.202 & 5.583 & 2.381 & -0.623 & 0.481 & 99.307 \\
3.0 & 0.48 & 3.426 & 5.915 & 2.489 & -0.996 & 0.854 & 98.769 \\
4.0 & 0.60 & 2.825 & 5.305 & 2.480 & -1.057 & 0.915 & 98.681 \\
5.0 & 0.70 & 2.341 & 5.075 & 2.734 & -1.097 & 0.955 & 98.623 \\
6.5 & 0.81 & 2.667 & 5.813 & 3.146 & -1.105 & 0.963 & 98.612 \\
9.5 & 0.98 & 3.242 & 5.582 & 2.340 & -1.090 & 0.948 & 98.633 \\
21.5 & 1.33 & 3.228 & 5.384 & 2.156 & -1.133 & 0.991 & 98.571 \\
29.5 & 1.47 & 3.401 & 5.558 & 2.157 & -1.294 & 1.152 & 98.339 \\
45.5 & 1.66 & 3.277 & 5.470 & 32.193 & -1.356 & 1.214 & 98.250 \\
59.5 & 1.77 & 3.514 & 4.867 & 1.353 & -1.490 & 1.348 & 98.057 \\
75.5 & 1.88 & 3.772 & 4.967 & 1.195 & -1.549 & 1.407 & 97.972 \\
82.5 & 1.92 & 3.527 & 5.025 & 1.498 & -1.654 & 1.512 & 97.820 \\
147.5 & 2.17 & 3.350 & 4.957 & 1.607 & -1.719 & 1.577 & 97.727 \\
153.5 & 2.19 & 3.024 & 5.032 & 2.008 & -1.832 & 1.690 & 97.564 \\
169.5 & 2.23 & 3.220 & 4.904 & 1.684 & -1.896 & 1.754 & 97.472 \\
177.5 & 2.25 & 3.152 & 5.053 & 1.901 & -1.992 & 1.850 & 97.333 \\
194.5 & 2.29 & 3.096 & 4.882 & 1.786 & -2.048 & 1.906 & 97.252 \\
217.5 & 2.34 & 3.541 & 4.933 & 1.392 & -2.252 & 2.110 & 96.958 \\
222.5 & 2.35 & 2.864 & 4.867 & 2.003 & -2.327 & 2.185 & 96.850 \\
241.5 & 2.38 & 3.198 & 4.959 & 1.761 & -2.391 & 2.249 & 96.758
\end{tabular}


Table D.4.C - Data for Test 非C - FAJA Shale, 3207-FT DEPTH, Core 非1 VOLUME $=71.78 \mathrm{~cm}^{3}, 125^{\circ} \mathrm{C}$

Run started on $10 / 21 / 87$; ended on $10 / 31 / 87$

Pressure in $\mathrm{MPa} \quad$ Volume in $\mathrm{cm}^{3}$

\begin{tabular}{|c|c|c|c|c|c|c|c|}
\hline Time/Hr & LOG $t$ & $\mathrm{Pp}$ & Pc & $\mathrm{Pe}$ & R. $V$ & $\nabla V$ & $V / V_{0}$ \\
\hline 2.0 & 0.30 & 3.213 & 5.583 & 2.370 & -1.632 & 0.571 & 99.205 \\
\hline 3.0 & 0.48 & 4.215 & 5.915 & 1.700 & -2.577 & 1.516 & 97.888 \\
\hline 4.0 & 0.60 & 3.917 & 5.305 & 1.388 & -2.794 & 1.733 & 97.586 \\
\hline 5.0 & 0.70 & 4.356 & 5.075 & 0.719 & -3.014 & 1.953 & 97.279 \\
\hline 6.5 & 0.81 & 4.369 & 5.813 & 1.444 & -3.383 & 2.322 & 96.765 \\
\hline 9.5 & 0.98 & 4.892 & 5.582 & 0.690 & -3.852 & 2.791 & 96.112 \\
\hline 21.5 & 1.33 & 4.820 & 5.384 & 0.564 & -4.170 & 3.109 & 95.669 \\
\hline 29.5 & 1.47 & 5.294 & 5.558 & 0.264 & -5.592 & 4.531 & 93.688 \\
\hline 59.5 & 1.77 & 4.724 & 4.867 & 0.1435 & leak & -1.061 & 101.478 \\
\hline 223.5 & 2.35 & 2.755 & 5.374 & 2.619 & 3.418 & -4.479 & 106.240 \\
\hline 288.5 & 2.46 & 2.868 & 5.494 & 2.626 & 3.477 & -4.538 & 106.322 \\
\hline 296.5 & 2.47 & 2.806 & 5.565 & 2.759 & 3.466 & -4.527 & 106.307 \\
\hline 311.5 & 2.49 & 2.785 & 5.505 & 2.720 & 3.477 & -4.538 & 106.322 \\
\hline 320.5 & 2.51 & 2.767 & 5.461 & 2.694 & 3.475 & -4.536 & 106.319 \\
\hline 336.5 & 2.53 & 2.782 & 5.498 & 2.716 & 3.481 & -4.542 & 106.328 \\
\hline 344.5 & 2.54 & 2.792 & 5.565 & 2.773 & 3.476 & -4.537 & 106.321 \\
\hline 359.5 & 2.56 & 2.740 & 5.498 & 2.758 & 3.475 & -4.536 & 106.319 \\
\hline 368.5 & 2.57 & 2.744 & 5.509 & 2.765 & 3.476 & -4.537 & 106.321 \\
\hline 384.5 & 2.58 & 2.784 & 5.517 & 2.733 & 3.476 & -4.537 & 106.321 \\
\hline 392.5 & 2.59 & 2.748 & 5.520 & 2.772 & 3.476 & -4.537 & 106.321 \\
\hline
\end{tabular}


Table D.5.a - Data for Test \#5a - FAJA Shale, 3202-ft depth, Core 非9 Volume $=85.16 \mathrm{~cm}^{3}$, Density $1.93 \mathrm{gm} / \mathrm{cm}^{3}, 125^{\circ} \mathrm{C}$

Run started on $3 / 3 / 87$; ended on $4 / 16 / 87$

Pressure in $\mathrm{MPa} \quad$ Volume in $\mathrm{cm}^{3}$

\begin{tabular}{|c|c|c|c|c|c|c|c|}
\hline Time $/ \mathrm{Hr}$ & LOG $t$ & $\mathrm{Pp}$ & $\mathrm{PC}$ & $\mathrm{Pe}$ & R. V & $\nabla \mathrm{V}$ & $V / V_{0}$ \\
\hline 15.0 & 1.18 & 1.091 & 5.652 & 4.561 & 2.183 & 0.330 & 99.612 \\
\hline 24.0 & 1.38 & 2.460 & 5.799 & 3.339 & 1.594 & 0.919 & 98.921 \\
\hline 47.5 & 1.68 & 2.480 & 5.624 & 3.144 & 0.965 & 1.548 & 98.182 \\
\hline 111.5 & 2.05 & 1.252 & 5.321 & 4.069 & -0.101 & 2.614 & 96.93 \\
\hline 120.5 & 2.08 & 2.242 & 5.314 & 3.072 & -0.951 & 3.464 & 95.93 \\
\hline 140.5 & 2.15 & 1.943 & 5.264 & 3.321 & -1.213 & 3.726 & 95.62 \\
\hline 144.5 & 2.16 & 2.375 & 5.466 & 3.091 & -1.325 & 3.838 & 95.49 \\
\hline 159.5 & 2.20 & 1.872 & 5.226 & 3.354 & -1.480 & 3.993 & 95.31 \\
\hline 167.5 & 2.22 & 2.475 & 5.750 & 3.296 & -1.590 & 4.103 & 95.18 \\
\hline 183.5 & 2.26 & 2.246 & 5.383 & 3.137 & -1.709 & 4.222 & 95.04 \\
\hline 360.5 & 2.56 & 2.564 & 5.473 & 2.909 & -2.640 & 5.153 & 93.94 \\
\hline 376.0 & 2.58 & 2.252 & 5.476 & 3.224 & -2.704 & 5.217 & 93.87 \\
\hline 384.0 & 2.58 & 2.714 & 5.731 & 3.017 & -2.750 & 5.263 & 93.82 \\
\hline 399.0 & 2.60 & 2.698 & 5.426 & 2.728 & -2.799 & 5.312 & 93.76 \\
\hline 407.0 & 2.61 & 2.775 & 5.312 & 2.537 & -2.836 & 5.349 & 93.71 \\
\hline 461.0 & 2.66 & 2.391 & 5.493 & 3.102 & -2.959 & 5.472 & 93.57 \\
\hline 470.0 & 2.67 & 2.660 & 5.549 & 2.889 & -3.026 & 5.539 & 93.49 \\
\hline 486.0 & 2.69 & 2.307 & 5.232 & 2.925 & -3.083 & 5.596 & 93.42 \\
\hline 494.0 & 2.69 & 2.631 & 5.330 & 2.699 & -3.125 & 5.638 & 93.38 \\
\hline 510.0 & 2.71 & 2.443 & 5.442 & 2.999 & -3.152 & 5.665 & 93.34 \\
\hline 518.0 & 2.71 & 2.567 & 5.517 & 2.950 & -3.184 & 5.697 & 93.31 \\
\hline 542.0 & 2.73 & 2.710 & 5.586 & 2.876 & -3.244 & 5.757 & 93.24 \\
\hline 557.0 & 2.75 & 2.536 & 5.560 & 3.024 & -3.288 & 5.796 & 93.19 \\
\hline 566.0 & 2.75 & 2.551 & 5.511 & 2.960 & -3.314 & 5.827 & 93.15 \\
\hline 639.0 & 2.81 & 2.455 & 5.317 & 2.862 & -3.474 & 5.987 & 92.97 \\
\hline 662.0 & 2.82 & 2.569 & 5.449 & 2.880 & -3.532 & 6.045 & 92.90 \\
\hline 686.0 & 2.84 & 2.669 & 5.455 & 2.786 & -3.595 & 6.108 & 92.82 \\
\hline 710.0 & 2.85 & 2.478 & 5.482 & 3.004 & -3.636 & 6.149 & 92.77 \\
\hline 733.5 & 2.87 & 2.491 & 5.564 & 3.073 & -3.697 & 6.210 & 92.70 \\
\hline 805.5 & 2.91 & 2.333 & 5.616 & 3.283 & -3.829 & 6.342 & 92.55 \\
\hline 829.5 & 2.92 & 2.531 & 5.299 & 2.768 & -3.917 & 6.430 & 92.45 \\
\hline 852.5 & 2.93 & 2.751 & 5.452 & 2.701 & -3.977 & 6.490 & 92.37 \\
\hline 877.5 & 2.94 & 2.601 & 5.554 & 2.953 & -4.011 & 6.524 & 92.33 \\
\hline 901.5 & 2.95 & 2.667 & 5.522 & 2.855 & -4.071 & 6.584 & 92.26 \\
\hline 997.5 & 3.00 & 2.458 & 5.572 & 3.114 & -4.214 & 6.727 & 92.101 \\
\hline
\end{tabular}


Table D.5.b - Data for Test 非b - FAJA Shale, 3206-ft depth, Core 非 Volume $=78.65 \mathrm{~cm}^{3}$, Density $1.92 \mathrm{gm} / \mathrm{cm}^{3}, 125^{\circ} \mathrm{C}$

Run started on $3 / 3 / 87$; ended on $4 / 16 / 87$

\section{Pressure in $\mathrm{MPa} \quad$ Volume in $\mathrm{cm}^{3}$}

\begin{tabular}{|c|c|c|c|c|c|c|c|}
\hline Time/HI & LOG $t$ & $\mathrm{Pp}$ & Pc & $\mathrm{Pe}$ & R. V & $\nabla V$ & $V / V_{0}$ \\
\hline 15.0 & 1.18 & 1.598 & 5.652 & 4.054 & 1.464 & 1.049 & 98.666 \\
\hline 24.0 & 1.38 & 2.742 & 5.799 & 3.057 & 1.140 & 1.373 & 98.254 \\
\hline 47.5 & 1.68 & 2.520 & 5.624 & 3.104 & 0.965 & 1.548 & 98.032 \\
\hline 111.5 & 2.05 & 2.181 & 5.321 & 3.140 & -0.358 & 2.871 & 96.350 \\
\hline 120.5 & 2.08 & 2.550 & 5.314 & 2.764 & -0.600 & 3.113 & 96.042 \\
\hline 140.5 & 2.15 & 2.002 & 5.264 & 3.262 & -0.781 & 3.294 & 95.812 \\
\hline 144.5 & 2.16 & 2.504 & 5.466 & 2.962 & -0.860 & 3.373 & 95.711 \\
\hline 159.5 & 2.20 & 2.101 & 5.226 & 3.125 & -0.993 & 3.506 & 95.542 \\
\hline 167.5 & 2.22 & 2.520 & 5.750 & 3.230 & -1.064 & 3.577 & 95.452 \\
\hline 183.5 & 2.26 & 2.476 & 5.383 & 2.907 & -1.149 & 3.662 & 95.344 \\
\hline 360.5 & 2.56 & 2.624 & 5.473 & 2.849 & -1.967 & 4.480 & 94.304 \\
\hline 376.0 & 2.58 & 2.266 & 5.476 & 3.210 & -2.018 & 4.531 & 94.239 \\
\hline 384.0 & 2.58 & 2.661 & 5.731 & 3.070 & -2.057 & 4.570 & 94.189 \\
\hline 399.0 & 2.60 & 2.712 & 5.426 & 2.714 & -2.104 & 4.617 & 94.130 \\
\hline 407.0 & 2.61 & 2.681 & 5.312 & 2.631 & -2.134 & 4.647 & 94.092 \\
\hline 461.0 & 2.66 & 2.529 & 5.493 & 2.964 & -2.242 & 4.755 & 93.954 \\
\hline 470.0 & 2.67 & 2.660 & 5.549 & 2.889 & -2.304 & 4.817 & 93.875 \\
\hline 486.0 & 2.69 & 2.293 & 5.232 & 2.939 & -2.355 & 4.868 & 93.811 \\
\hline 494.0 & 2.69 & 2.665 & 5.330 & 2.665 & -2.399 & 4.912 & 93.755 \\
\hline 510.0 & 2.71 & 2.592 & 5.442 & 2.850 & -2.428 & 4.941 & 93.718 \\
\hline 518.0 & 2.71 & 2.512 & 5.517 & 3.005 & -2.440 & 4.953 & 93.702 \\
\hline 542.0 & 2.73 & 2.684 & 5.586 & 2.902 & -2.481 & 4.994 & 93.650 \\
\hline 557.0 & 2.75 & 2.591 & 5.560 & 2.969 & -2.527 & 5.040 & 93.592 \\
\hline 566.0 & 2.75 & 2.682 & 5.511 & 2.829 & -2.564 & 5.077 & 93.545 \\
\hline 639.0 & 2.81 & 2.469 & 5.317 & 2.848 & -2.706 & 5.219 & 93.364 \\
\hline 662.0 & 2.82 & 2.589 & 5.449 & 2.860 & -2.755 & 5.268 & 93.302 \\
\hline 686.0 & 2.84 & 2.696 & 5.455 & 2.759 & -2.810 & 5.323 & 93.232 \\
\hline 710.0 & 2.85 & 2.989 & 5.482 & 2.493 & -2.849 & 5.362 & 93.182 \\
\hline 733.5 & 2.87 & 2.641 & 5.564 & 2.923 & -2.910 & 5.423 & 93.105 \\
\hline 805.5 & 2.91 & 2.407 & 5.616 & 3.209 & -3.024 & 5.537 & 92.960 \\
\hline 829.5 & 2.92 & 2.539 & 5.299 & 2.760 & -3.103 & 5.616 & 92.860 \\
\hline 852.5 & 2.93 & 2.683 & 5.452 & 2.769 & -3.156 & 5.669 & 92.792 \\
\hline 877.5 & 2.94 & 2.663 & 5.554 & 2.891 & -3.189 & 5.702 & 92.750 \\
\hline 901.5 & 2.95 & 2.659 & 5.522 & 2.863 & -3.239 & 5.752 & 92.687 \\
\hline 997.5 & 3.00 & 2.617 & 5.572 & 2.955 & -3.384 & 5.897 & 92.502 \\
\hline
\end{tabular}


Tabel D.5.c - Data for Test \#5c - FAJA Heavy 0il Sandstone, 3278-ft depth, Core 非0 Volume $=40.68 \mathrm{~cm}^{3}$, Density $1.89 \mathrm{gm} / \mathrm{cm}^{3}, 125^{\circ} \mathrm{C}$

Run started on $3 / 3 / 87$; ended on $4 / 16 / 87$

Pressure in $\mathrm{MPa} \quad$ Volume in $\mathrm{cm}^{3}$

\begin{tabular}{llllllll} 
Time/Hr & LOG $\mathrm{t}$ & $\mathrm{Pp}$ & $\mathrm{Pc}$ & $\mathrm{Pe}$ & $\mathrm{R} . \mathrm{V}$ & $\nabla \mathrm{V}$ & $\mathrm{V} / V_{0}$ \\
\hline 15.0 & 1.18 & 2.925 & 5.652 & 2.727 & 2.429 & 0.343 & 99.157 \\
24.0 & 1.38 & 2.835 & 5.799 & 2.964 & 2.206 & 0.566 & 98.609 \\
47.5 & 1.68 & 2.869 & 5.624 & 2.755 & 1.991 & 0.781 & 98.080 \\
111.5 & 2.05 & 2.568 & 5.321 & 2.753 & 0.974 & 1.798 & 95.580 \\
120.5 & 2.08 & 2.753 & 5.314 & 2.561 & 0.836 & 1.936 & 95.241 \\
140.5 & 2.15 & 2.852 & 5.264 & 2.412 & 0.623 & 2.149 & 94.717 \\
144.5 & 2.16 & 2.750 & 5.466 & 2.716 & 0.607 & 2.165 & 94.678 \\
159.5 & 2.20 & 2.829 & 5.226 & 2.397 & 0.450 & 2.322 & 94.292 \\
167.5 & 2.22 & 3.144 & 5.750 & 2.606 & 0.400 & 2.372 & 94.169 \\
183.5 & 2.26 & 2.901 & 5.383 & 2.482 & 0.291 & 2.481 & 93.901 \\
360.5 & 2.56 & 2.870 & 5.473 & 2.603 & -0.308 & 3.080 & 92.429 \\
376.0 & 2.58 & 2.847 & 5.476 & 2.629 & -0.372 & 3.144 & 92.271 \\
384.0 & 2.58 & 2.802 & 5.731 & 2.929 & -0.373 & 3.145 & 92.269 \\
399.0 & 2.60 & 2.865 & 5.426 & 2.561 & -0.436 & 3.208 & 92.114 \\
407.0 & 2.61 & 2.711 & 5.312 & 2.601 & -0.436 & 3.208 & 92.114 \\
461.0 & 2.66 & 2.966 & 5.493 & 2.527 & -0.577 & 3.349 & 91.767 \\
470.0 & 2.67 & 2.817 & 5.549 & 2.732 & -0.596 & 3.368 & 91.721 \\
486.0 & 2.69 & 2.807 & 5.232 & 2.425 & -0.671 & 3.443 & 91.536 \\
494.0 & 2.69 & 2.982 & 5.330 & 2.348 & -0.696 & 3.468 & 91.475 \\
510.0 & 2.71 & 2.754 & 5.442 & 2.688 & -0.715 & 3.487 & 91.428 \\
518.0 & 2.71 & 2.916 & 5.517 & 2.601 & -0.742 & 3.514 & 91.362 \\
542.0 & 2.73 & 2.758 & 5.586 & 2.828 & -0.789 & 3.561 & 91.246 \\
557.0 & 2.75 & 2.950 & 5.560 & 2.610 & -0.836 & 3.608 & 91.131 \\
566.0 & 2.75 & 2.909 & 5.511 & 2.602 & -0.859 & 3.631 & 91.074 \\
639.0 & 2.81 & 2.801 & 5.317 & 2.516 & -1.018 & 3.790 & 90.683 \\
662.0 & 2.82 & 2.970 & 5.449 & 2.479 & -1.083 & 3.855 & 90.524 \\
686.0 & 2.84 & 2.805 & 5.455 & 2.650 & -1.130 & 3.902 & 90.408 \\
710.0 & 2.85 & 2.994 & 5.482 & 2.488 & -1.206 & 3.978 & 90.221 \\
733.5 & 2.87 & 3.118 & 5.564 & 2.446 & -1.283 & 4.055 & 90.032 \\
805.5 & 2.91 & 2.849 & 5.616 & 2.767 & -1.434 & 4.206 & 89.661 \\
829.5 & 2.92 & 2.894 & 5.299 & 2.405 & -1.520 & 4.292 & 89.449 \\
852.5 & 2.93 & 2.876 & 5.452 & 2.576 & -1.583 & 4.355 & 89.294 \\
877.5 & 2.94 & 2.844 & 5.554 & 2.710 & -1.630 & 4.402 & 89.179 \\
901.5 & 2.95 & 2.750 & 5.522 & 2.772 & -1.689 & 4.461 & 89.034 \\
997.5 & 3.00 & 3.011 & 5.572 & 2.561 & -1.904 & 4.676 & 88.505
\end{tabular}

